\title{
Thermo-hydraulic conditions in a seismically active zone (Gulf of Corinth, Greece)
}

\author{
Zur Erlangung des akademischen Grades eines \\ DOKTORS DER NATURWISSENSCHAFTEN \\ von der Fakultät für \\ Bauingenieur-, Geo- und Umweltwissenschaften \\ der Universität Fridericiana zu Karlsruhe (TH) \\ genehmigte \\ DISSERTATION \\ von \\ Dipl.-Geol. Detlev Rettenmaier \\ aus Aalen / Ostalbkreis
}

\begin{abstract}
Tag der mündlichen Prüfung: $\quad$ 18.07.2007
Hauptreferent: $\quad$ Univ.-Prof. Dr.phil. H. Hötzl

Korreferentin: Dr. habil. A. Förster
\end{abstract}

Karlsruhe 2007 


\begin{abstract}
In this thesis the thermo-hydraulic conditions of a seismically active zone have been investigated by means of surface and subsurface investigations, borehole studies and numerical modeling. European research activities in the Gulf of Corinth have been targeted for obtaining data on earthquake sources and fault mechanics and for investigating the role of faults on fluid flow in this seismically active area. In this context, the DFG funded a project aimed at the exploration of the thermo-hydraulic conditions in the area near Aigion and the southern graben shoulder of the northern Peloponnesus including the determination of surface heat flow in a $1000 \mathrm{~m}$ deep borehole, which is the scope of this work.
\end{abstract}

First, due to a lack of geological information, a detailed investigation of the geological and tectonical situation was made. Secondly, the hydraulic parameters of the different lithological formations and of the hydraulic behavior of normal faults were determined.

Based on the field studies, hydraulic testing, petrophysical well-log analysis, optical-fiber temperature sensing, and laboratory measurement of thermal conductivity, a hydrogeological conceptual model was prepared. This conceptual model formed the basis for a numerical 2-D model of the hydraulic conditions at regional scale at the southern Corinth graben shoulder. Different simulation scenarios were investigated to search for the best-fit model to known parameters.

Coupled numerical modeling of groundwater flow and heat transport was then used to get insights in the processes that may be typical for the study area. In the case of the Corinth area, model calibration, as well as sensitivity and plausibility checks allow a prediction on how the thermo-hydraulic system in this seismically active zone is characterized and how the hydraulic conditions affect the heat flow. Surface heat-flow density was unknown in the northern Peloponnesus prior this study. Also unknown was whether the water flow in aquifers results in strong heat advection signals in the temperature field.

The coupling of temperature and geothermal parameters to the calibrated hydraulic flow model has shown that some of the intervals are affected by heat advection due to fluid flow, affecting the temperature gradient and hence the heat flow. In a pure conduction heat regime the measured temperature of $32^{\circ} \mathrm{C}$ from $750 \mathrm{~m}$ depth would be increase to $37^{\circ} \mathrm{C}$. At the lower model boundary of $1155 \mathrm{~m}$ depth the maximal temperature in the conductive $1-\mathrm{D}$ temperature profile is $45^{\circ} \mathrm{C}$ which is approximately $4.5^{\circ} \mathrm{C}$ higher than in the coupled thermo-hydraulic flow model. The examination of coupled modeling runs has shown that conductive heat flow of the crust is about $55 \mathrm{~mW} / \mathrm{m}^{2}$.

Finally, it is clear that the quality of input data is playing a major role for the best fitting of a numerical model. Otherwise it was also shown that sometimes generalization is necessary when general restrictions from the modeling software are required. Undoubtedly, the fault zones of the Gulf of Corinth are representing one case of seismic zones and similar model approaches can be extended to other hydraulic systems with similar tectonical arrangements. 


\section{Kurzfassung}

Das übergeordnete Ziel der vorliegenden Arbeit war die Untersuchung des thermo-hydraulischen Regimes an einer seismisch aktiven Zone. Dabei wurde evaluiert, inwiefern hydraulische Verhältnisse im Untergrund charakterisiert werden können und inwiefern sich Abschiebungszonen im Untergrund auf die Hydraulik auswirken. Es wurde untersucht, in welchem Maße das hydraulische System Einfluss auf das geothermische Umfeld und den Wärmefluss im Bereich einer $1000 \mathrm{~m}$ Tiefenbohrung nimmt. Die angewendete Methodik gliedert sich dabei in geologische und hydrogeologische Untersuchungen an der Oberfläche und im Untergrund, Bohrlochinterpretationen, geophysikalische Auswerteverfahren und Laboranalysen, sowie einer abschließenden numerischen Modellierung.

Wegen fehlenden geologisch-tektonischen Informationen im Untersuchungsgebiet wurde anhand einer umfassenden Kartierung das typische Gesteinsinventar und die tektonischen Strukturen erörtert. Hydraulische Tests wie Pumpversuche und Fördertests im Bereich von Abschiebungen im Hinterland und in der Tiefenbohrung haben Aufschluss über hydraulische Parameter und Hinweise auf das vorhandene hydraulische System gegeben. Durch hydrochemische Analysen und Grundwasserdatierungen wurden die hydrogeologischen Erkenntnisse erweitert.

Durch die persönliche geologische Betreuung der Tiefenbohrung durch den Autor konnte eine detaillierte Lithologie und tektonische Analyse anhand von Bohrklein und Kernen bis zu einer Tiefe von 1000 Metern erstellt werden. Die Auswertung von geophysikalischen Logs verfeinerte die geologisch-tektonische Interpretation und führte zu einem ausgedehnten Nord-Süd Profil, in denen die Strukturen und das typische Gesteinsinventar der alpidisch überprägten Olonos-Pindos Deckeneinheit dargestellt wurden. In einem konzeptionellen hydraulischen Modell wurden anschließend alle erhaltenen Daten integriert. Das konzeptionelle Modell basiert auf dem geologischen N-S Profil mit der Tiefenbohrung und einer seismisch aktiven Abschiebungszone als zentralem Element. Es stellt das Grundgerüst der numerischen Modellierung dar.

Die thermischen Parameter zur Berechnung des Wärmeflusses wurden zum Einen aus einem gemessenen Temperaturprofil und zum Anderen aus Labormessungen an Gesteinsproben gewonnen. Das Temperaturprofil diente zusätzlich zur Bestimmung des geothermischen Gradienten sowie der allgemein vorherrschenden Temperatur im Untergrund.

Bei der Umsetzung des konzeptionellen Modells in ein numerisches Modell wurde zuerst eine hydraulische Kalibrierung durchgeführt. Durch Plausibilitäts- und Sensitivitätsanalysen wurde das hydraulische Verhalten an der Abschiebungszone evaluiert. Erst nach der Erstellung von unterschiedlichen hydraulisch kalibrierten Modellen wurden die thermischen Parameter zugeschaltet.

Das gekoppelte numerische thermo-hydraulische Modell hat erfolgreich Bereiche dargestellt, an denen das geothermische Regime offensichtlich durch hydraulische Verhältnisse beeinflusst ist. Die aus den thermischen Leitfähigkeiten und dem geothermischen Gradienten errechneten Wärmeflusswerte sind durch die thermo-hydraulische Modellierung bestätigt worden.

Die Modellierung hat gezeigt, dass die lithologischen Intervalle und der Temperaturgradient und damit auch der Wärmefluss durch das hydraulische Regime gestört sind. Dabei wurde das bis $750 \mathrm{~m}$ unter GOK gemessene Temperaturprofil bis in eine Tiefe von $1155 \mathrm{~m}$ numerisch verlängert. In einem rein 
konduktiven Wärmeregime würde die in $750 \mathrm{~m}$ gemessene Temperatur von $32^{\circ} \mathrm{C}$ auf $>37^{\circ} \mathrm{C}$ ansteigen. An der untersten Modellgrenze von $1155 \mathrm{~m}$ wurde an verschiedenen Scenarios mit und ohne hydraulischer Strömung gezeigt, dass sich bei konduktiven Verhältnissen die Temperatur um $4,5^{\circ} \mathrm{C}$ im Vergleich zum gekoppelten Modell erhöht und Maximaltemperaturen von über $45^{\circ} \mathrm{C}$ erreicht werden. Der konduktive Wärmefluss der Kruste am Golf von Korinth beträgt durchschnittlich $55 \mathrm{~mW} / \mathrm{m}^{2}$.

Für das in der vorliegenden Arbeit erstellte numerische Modell waren umfangreiche und detaillierte Vorstudien notwendig, um vorerst eine gute Datengrundlage zu erschaffen. Damit konnten in einem multivariaten Modell Unsicherheiten durch eigene Analysen verringert werden und eine Wertschöpfung des numerischen Modells erreicht werden. Es ist klar, dass die beschriebene Herangehensweise für einen konkreten Fall tektonischer Störungen am Golf von Korinth entwickelt wurde. Jedoch stellt die vorgeschlagene Methodik auch ein kompetentes Werkzeug dar, mit dem man auch unbekannte Gebiete ähnlicher tektonischer Problematik generalisieren kann. 


\section{Contents}

Abstract

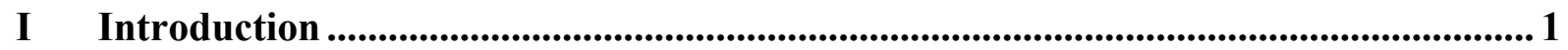

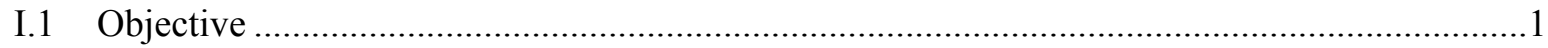

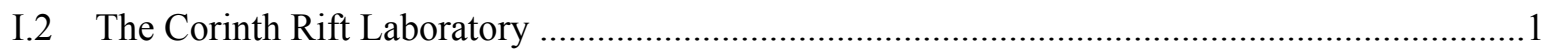

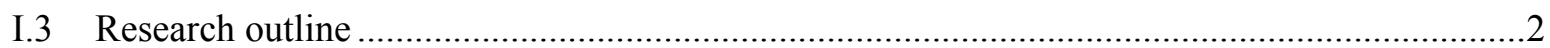

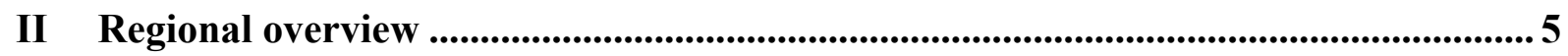

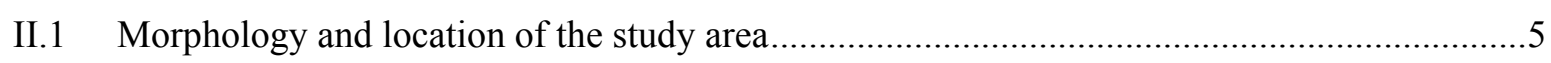

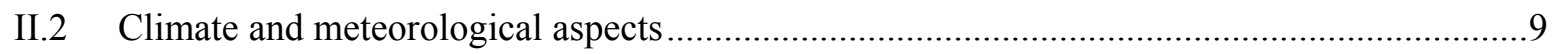

III Geological - tectonical setting ...................................................................................... 12

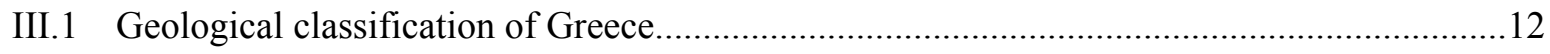

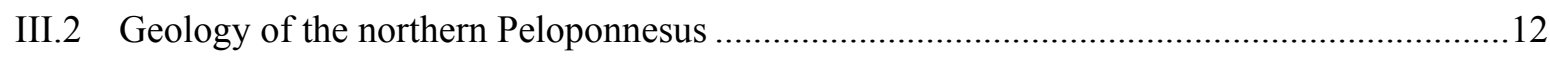

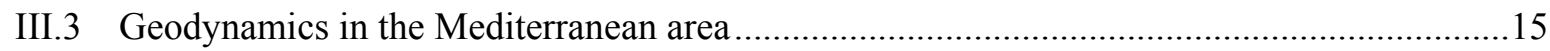

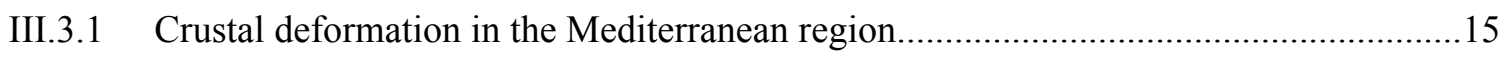

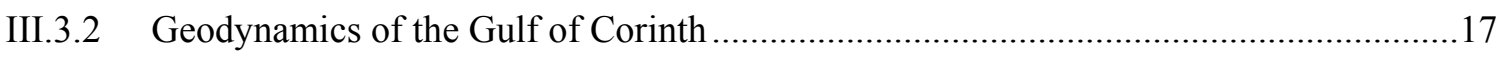

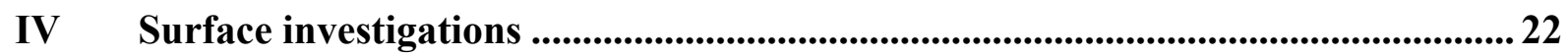

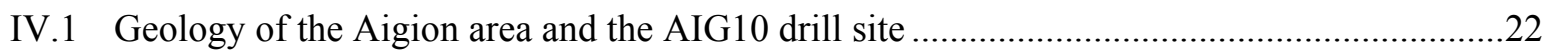

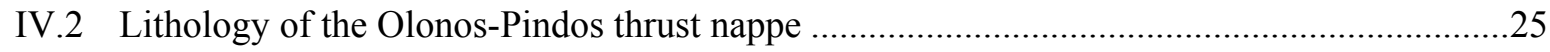

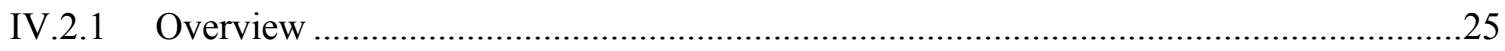

IV.2.2 Jurassic-lower Cretaceous Radiolarite Formation ..........................................................26

IV.2.3 Cretaceous-Tertiary Olonos-Pindos Platy Limestone Formation...................................27

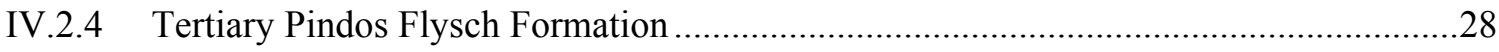




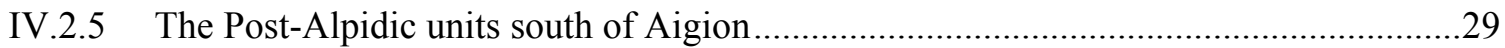

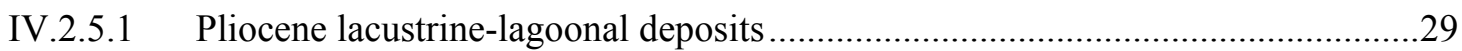

IV.2.5.2 Pliocene - Early Pleistocene Gilbert-type delta conglomerates .............................30

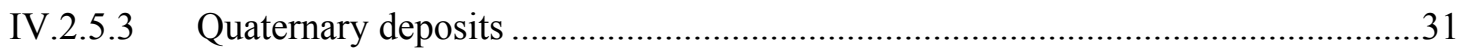

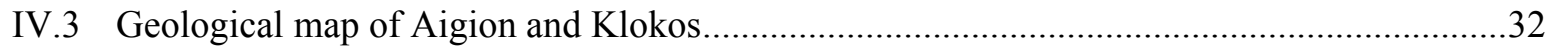

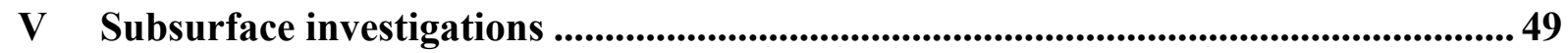

V.1 Parameter determination from the AIG10 borehole ........................................................49

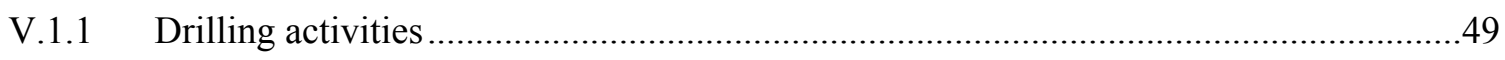

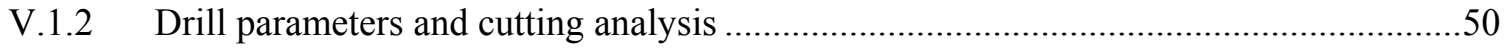

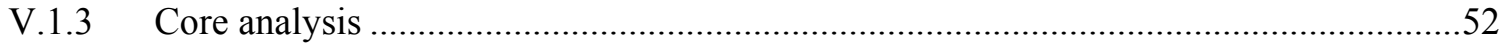

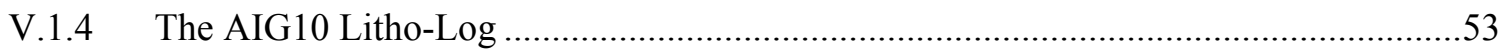

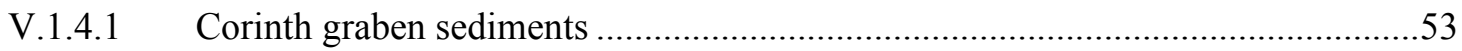

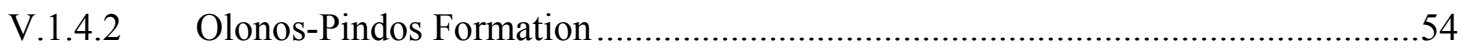

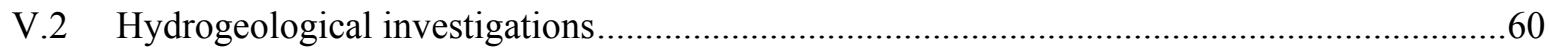

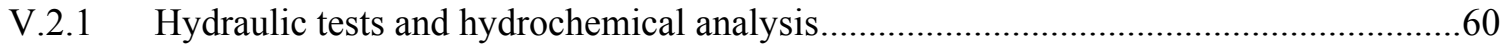

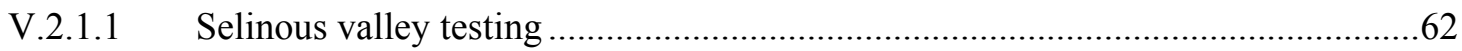

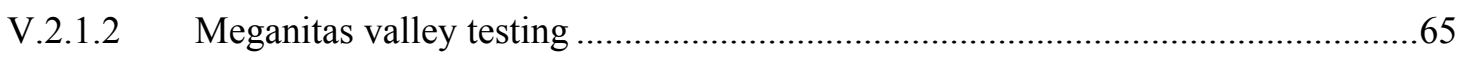

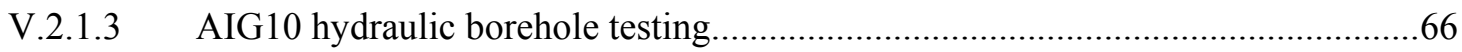

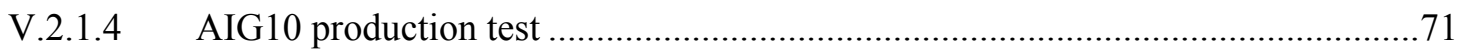

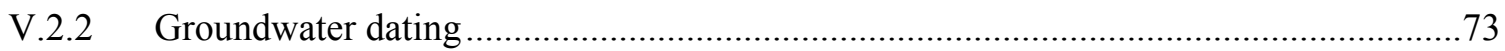

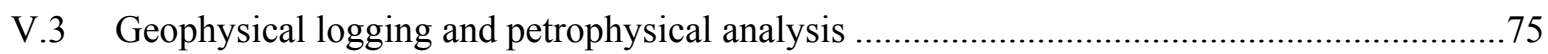

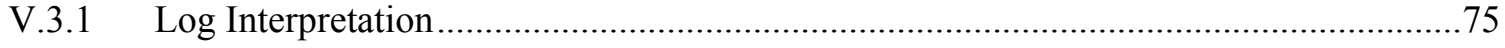

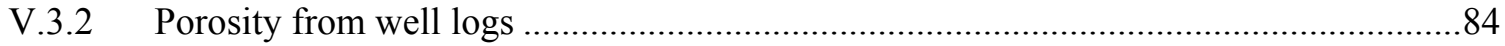

V.3.3 DTS temperature logging and heat flow determination ............................................... 87

VI Laboratory measurements of thermal conductivity and porosity ..........................92

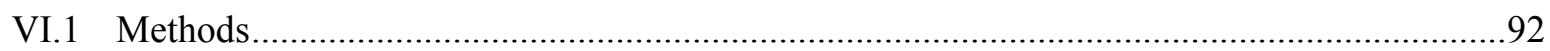

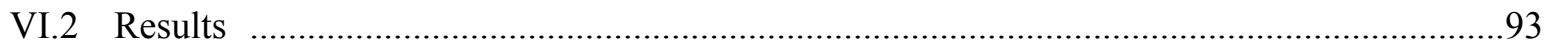


VII Numerical thermo-hydraulic model .....................................................................96

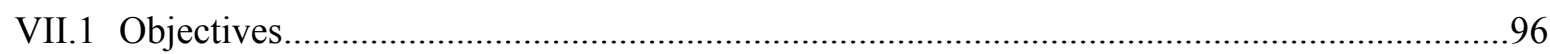

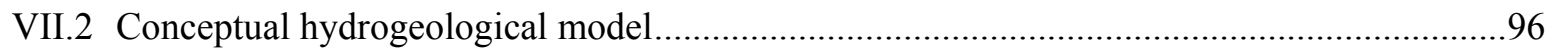

VII.3 Conversion of the conceptual model to a numerical model ................................................100

VII.3.1 Finite Element subsurface FLOW and transport simulation system FEFLOW ${ }^{\circledR}$.........100

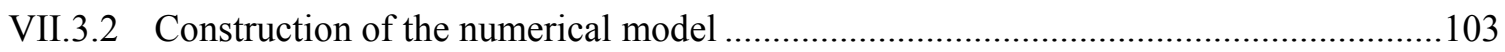

VII.4 Hydraulic calibration and flow model near faults ............................................................107

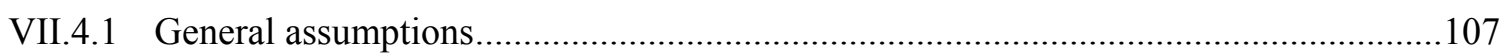

VII.4.2 Plausibility-, Sensibility-Check and starting conditions for flow.................................107

VII.4.2.1 Hydraulic conductivity attributed to the lithological elements ..............................108

VII.4.2.2 Hydraulic conductivity attributed to the fault elements.......................................108

VII.4.2.3 Hydraulic boundary conditions for flow.............................................................. 109

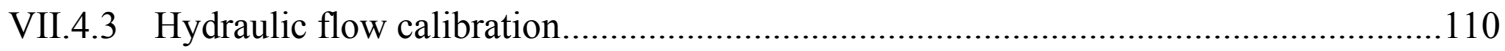

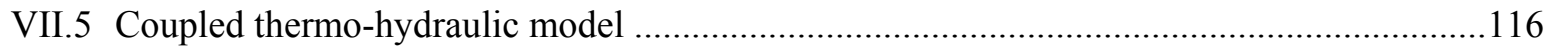

VII.5.1 Extension of the hydraulic flow model to thermal properties ......................................116

VII.5.2 Plausibility check and starting conditions for thermal properties ...............................117

VII.5.2.1 Thermal conductivity attributed to the lithological elements .............................118

VII.5.2.2 Thermal conductivity attributed to the fault elements .........................................118

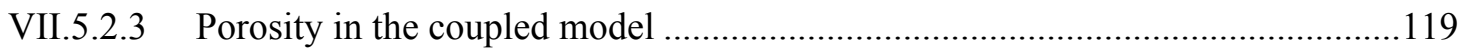

VII.5.2.4 Boundary conditions for temperature and heat flow..........................................119

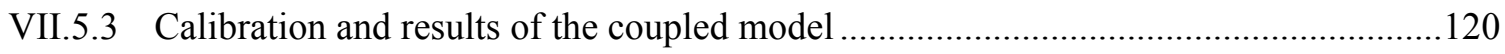

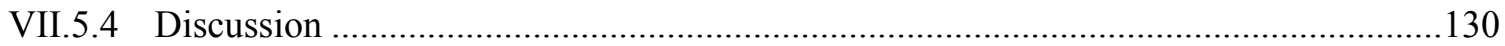

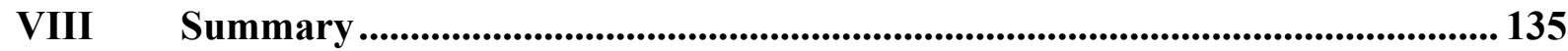

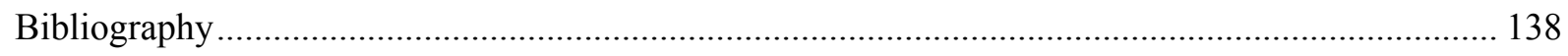

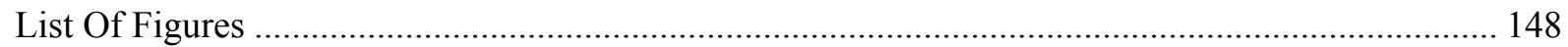

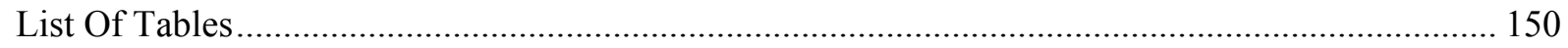

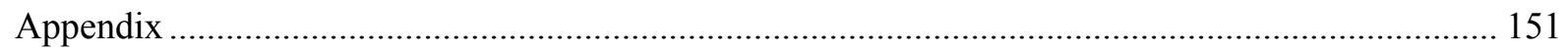

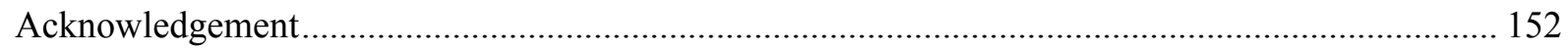




\section{Introduction}

\section{I.1 Objective}

In this thesis the thermo-hydraulic conditions in a seismically active zone have been investigated by means of surface- and sub-surface investigations, borehole studies and numerical modeling. The method is used to determine the surface heat flow at the seismic active southern shore of the Gulf of Corinth in Greece, in which the 1000-m deep borehole (AIG10) is located. The study comprises geologic-tectonical mapping, the performance and analysis of hydraulic experiments, hydrochemical and petrophysical analysis, geophysical well log analysis, as well as the modeling of a regional 2-D cross section. It focuses on the investigation of geology and tectonics, hydraulic fault behavior and the relationship between fluid flow and thermal properties. Knowledge of the subsurface hydraulics and of a temperature-depth profile are the basis to evaluate the mode of subsurface heat transfer and therewith the character or type of heat flow in the area. The numerical modeling and calibration of a hydrogeological conceptual model is targeted on the delineation of aquicludes and aquifers and the evaluation of which amount the supposedly undisturbed heat-flow density in the aquicludes might be affected by the fluid flow in the aquifers. Finally, it is of interest to which amount the temperature is rising in a 1-D temperature profile if pure conduction conditions are given.

\section{I.2 The Corinth Rift Laboratory}

The Gulf of Corinth and the northern part of the Peloponnesus peninsula, Greece, is known as one of the most active seismic zones in the world. It is presently one of the fastest opening continental graben systems with extension rates up to $1,5 \mathrm{~cm} /$ year. The approx. $120 \mathrm{~km} \mathrm{E-W} \mathrm{striking} \mathrm{seismic} \mathrm{active} \mathrm{rift}$ system is arranged within the Aegean Sea in the eastern Mediterranean (Fig. II.1). On June, 15, 1995 a large earthquake of magnitude Ms=6.2 (National Observatory Athens NOA) occurred in the vicinity of Aigion and initiated political discussions for the development of the in-situ earth sciences laboratory "Corinth Rift Laboratory Gulf of Corinth" (CRL).

As part of the CRL, the "Deep Geodynamic Laboratory" (DGLab) contributes to the development of a European seismic hazard research facility. Its main objective concerns the documentation of hydraulic and mechanical behavior of faults as well as the acquisition of data required for seismic risk mitigation. Another aspect is the monitoring of the mechanical behavior of faults through the instrumentation of deep boreholes intersecting active faults and for obtaining data on the physics of earthquakes and aseismic fault motion. This facility will also include a set of deep permanent seismic sensors to document seismic signals at depth. The DGLab-project is thus aimed at the development of an efficient research infrastructure.

The work of the doctoral thesis at hand interacts with the EU Corinth Rift Laboratory project CRL and its subprojects DGLAB, CORSEIS, 3F, and AEGIS. It is the result of investigations in the frame of the DFG project "Thermo-hydraulic conditions in the area of the Gulf of Corinth Deep Geodynamic Laboratory: Interpretation from Well-Logging and Modeling". 


\section{I.3 Research outline}

The work is structured into surface and subsurface investigations and a final modeling stage. It employs a multidisciplinary approach consisting of elements of geology, tectonics, hydrogeology, hydrochemistry, geophysics, petrophysics, and numerical modeling. Fig. I.1 highlights the approach and methods for the investigations of the thermo-hydraulic conditions in the study area.

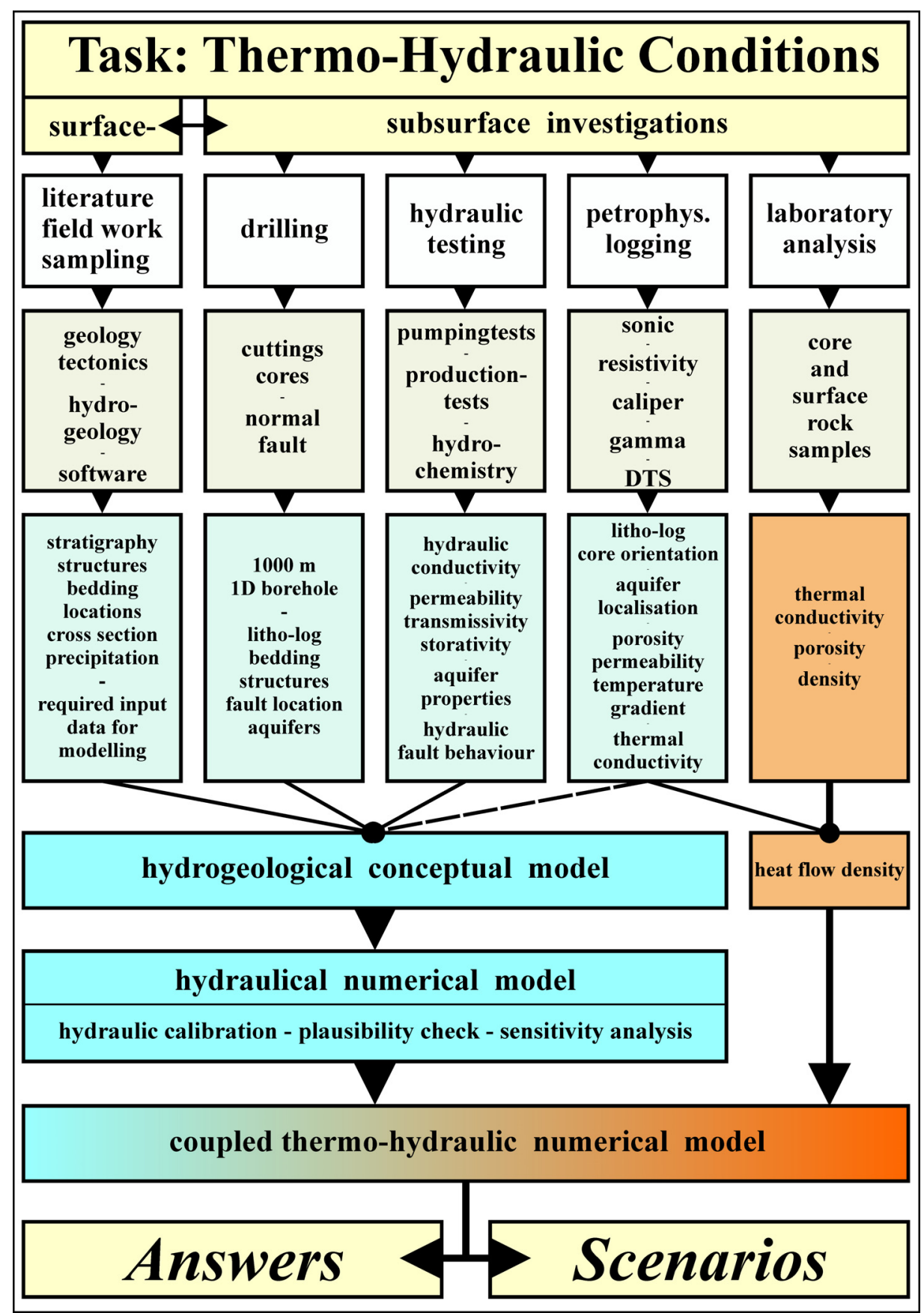

Fig. I.1: Overall concept of the project task: thermo-hydraulic conditions in the area of the „Gulf of Corinth Deep Geodynamic Laboratory“: Interpretation from well-logging and modeling. At first the goal was a general geological-tectonical and hydrogeological understanding of the area of interest. The method is subdivided in surface- and subsurface investigations which are integrated in a hydrogeological conceptual model with a final thermo-hydraulic numerical model of the area. 
Chapter I renders an initial insight into the objectives of this work and attempts to embrace the employed methods, data acquisition and the embedding of the work into the Corinth Rift Laboratory project. Chapter II comprises a regional overview about the geographical location and useful meteorological data of the study area. Before the starting of the detailed surface and subsurface investigations chapter III will give an overview about the geology and tectonics of Greece and the northern Peloponnesus, necessary to understand the overall geological-tectonical setting of the study area.

Due to the lack of geological and hydrogeological information and due to pilot investigations for the AIG10 drilling activities, intensive surface investigations were necessary (chapter IV). Geologically, the area is part of the Olonos-Pindos tectonic nappe, which is overthrusted on the Tripolitza unit during the Alpine orogeny. The typical lithology of the Olonos-Pindos Formation and characteristic tectonical structures are discussed in chapter IV.1 and chapter IV.2. A $80 \mathrm{~km}^{2}$ geologic-tectonic map including several cross sections for understanding the geological-tectonical structure and a $22 \mathrm{~km} \mathrm{~N}-\mathrm{S}$ cross section for the compilation of a hydrogeological conceptual model and definition of the model architecture is then developed in Chapter IV.3.

Chapter $\mathbf{V}$ provides all investigations performed in the subsurface of the study area. Chapter V.1 describes the drilling activities of the $1001 \mathrm{~m}$ deep AIG10 borehole and the determination of a detailed lithological log. Hydrochemical analyses of water from 89 springs and pumping stations as well as from six pumping tests combined with groundwater dating were performed for calibrating and verifying the conceptual model. Additionally, two open-hole pumping tests and one artesian production test were performed during the drilling activities of the AIG10 borehole. The performance and results of the hydrogeological investigations are described in chapter V.2 and were used to characterize the conditions in the AIG10 borehole.

In addition to field data, the recognition of stratification encountered in the AIG10 borehole was also based on online analysis of well cuttings, core descriptions, drilling parameters, and petrophysical and geophysical well-log interpretation. The processing and analysis of geophysical log interpretation and relevant parameters for numerical modeling is the topic of chapter V.3. An extensive portion of work had to be spent on the selection and application of correction routines and the use of computer-aided interpretation principles and methods (Doveton, 1994a, 1994b) to transform the well-log information into geologically relevant information. Finally, chapter V.3 includes the description and analysis of the temperature profile derived by the DTS method in AIG10 which was crucial for the determination of thermal gradients, regional heat flow and the generation of a coupled thermo-hydraulic numerical model. In this modeling the data from the thermal well-logging and the thermal properties of the relevant rocks determined in the laboratory (chapter VI) are incorporated.

Chapter VII consist of the performance of a numerical thermo-hydraulical model and starts with a description of a overall conceptual hydrogeological model (chapter VII.1 and VII.2). This conceptual model represents the fundament for the numerical model of the Aigion area and is subdivided into the area south of the Aigion Fault and the area north of the Aigion Fault with the deep borehole in its centre (chapter VII.3). Different hydraulic parameters such as porosity, permeability, and flux rate were verified in a first numerical flow model (chapter VII.4). After calibrating the flow model, the fluid dynamics in the numerical model was verified by variation of the hydraulic parameters for lihological units and for fault behavior. 
The extended coupled fluid flow / heat flow model was calibrated by a temperature-depth profile and is the topic of chapter VII.5. Finally, the chapter comprise a discussion of the results of the coupled thermo-hydraulic model.

The thesis closes in Chapter VIII with a summary and draws conclusions on the obtained results and the method used for the determination of the surface heat flow by the numerical thermo-hydraulic approach. 


\section{Regional overview}

\section{II.1 Morphology and location of the study area}

The Peloponnesus peninsula represents the most southern part of the Balkan area in the Mediterranean region. In the west the Peloponnesus is flanked by the Ionian Sea (Fig. II.1). The Isthmus of Corinth in the east links the Ionian and Aegean Sea and is here associated with the mainland of Greece in the north. To the south the Peloponnesus ends in the Saronic, Argolic, Lakonic and Messinic Gulfs. In the northwest the Gulf of Patra and in the north the Gulf of Corinth are separating the Peloponnesus peninsula from the mainland of Greece.

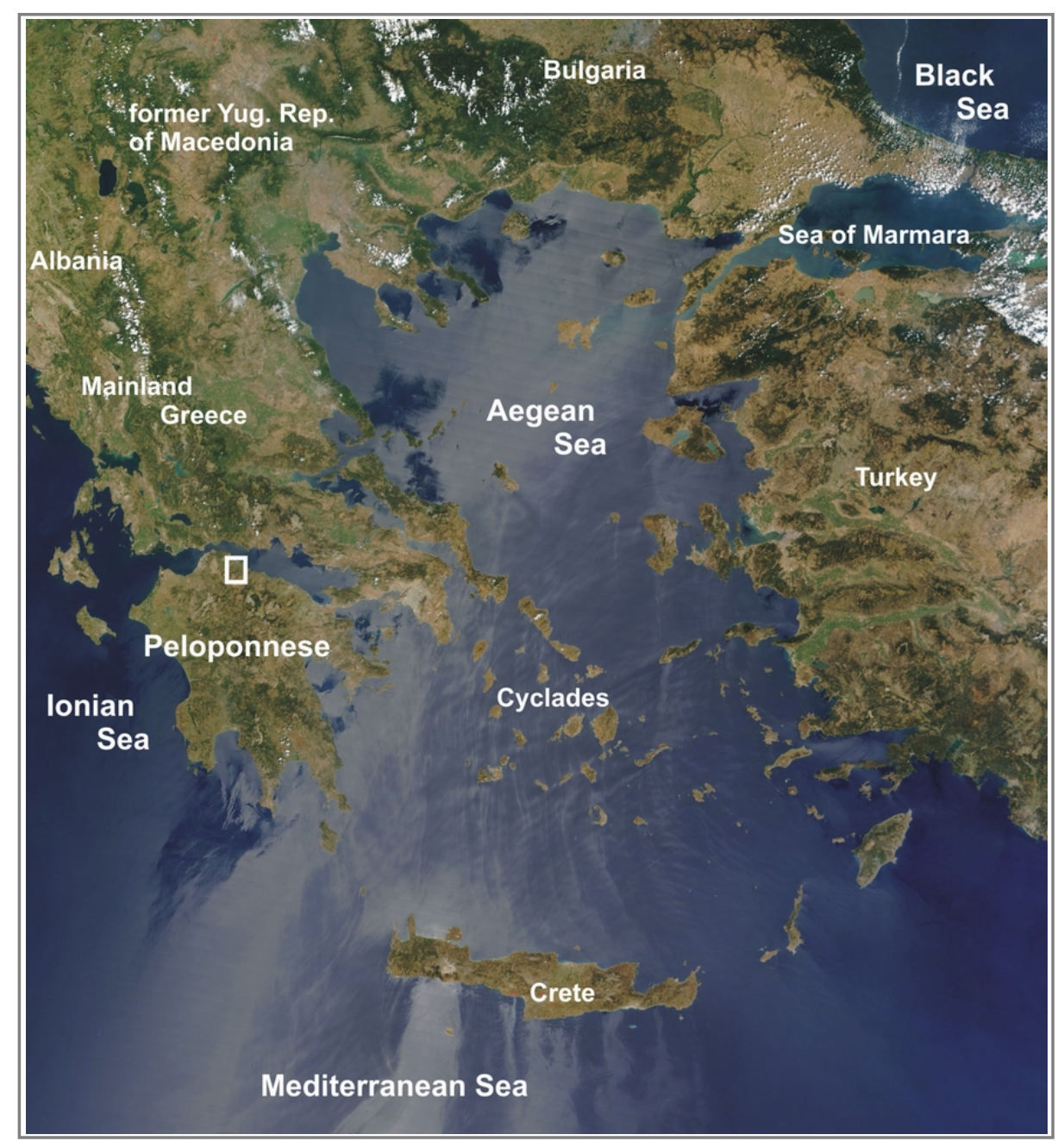

Fig. II.1: Modified NASA Satellite image of the Aegean region from 2003-07-23 with 250 m resolution. The Moderate Resolution Imaging Spectroradiometer (MODIS) image of Greece and the Aegean Sea is available on NASA's website Visible Earth (http://visibleearth.nasa.gov/images/5741/ Greece. A2003204 .0925.250m.jpg). The geographical arrangement of the continental crust is strong influenced by the tectonic evolution. The Eastern Mediterranean is dominated by effects of subduction along the Hellenic arc (Crete) and of continental collision of Turkey in the East. The Subduction zone (African plate boundary) is causing extension of the continental crust of the East Mediterranean province. On the left the approx. $110 \mathrm{~km}$ Gulf of Corinth is in evidence separating the Peloponnesus peninsula from the mainland of Greece. The Isthmus of Corinth links the Ionian and Aegean Sea. The Aegean extensional province is characterized by countless islands. The Sea of Marmara separates the Black Sea (top right) from the Aegean Sea. The white rectangle marks the approximately $90 \mathrm{~km}^{2}$ investigation area in the vicinity of Aigion. Details of the section is given in figure Fig. II.2. 
The relief of the Peloponnesus is characterized by three north-south striking mountain ranges. The highest mountain, Helmos, has a altitude of $2341 \mathrm{~m}$ and is located in the center of the Peloponnesus. In the northwest, the country is dominated of the mountain chains Erymanthos (max. $2224 \mathrm{~m}$ ) and Panachaikon (1926 m).

The study area

The study area for the preparation of the conceptual model by geological mapping and hydrogeological investigations is covering approx. $100 \mathrm{~km}^{2}$ of the vicinity of Aigion which is located $40 \mathrm{~km}$ east of Achaia's capital city Patra and $210 \mathrm{~km}$ west of Athens at the southern coastline of the Gulf of Corinth (Fig. II.2). The study area is part of the North Panachaikon domain within the Achaia prefecture where the Klokos mountain represents the maximum topographic height of $1779 \mathrm{~m}$ to the south. The maximum distance between the Gulf and the southern point of the study area is $25 \mathrm{~km}$.

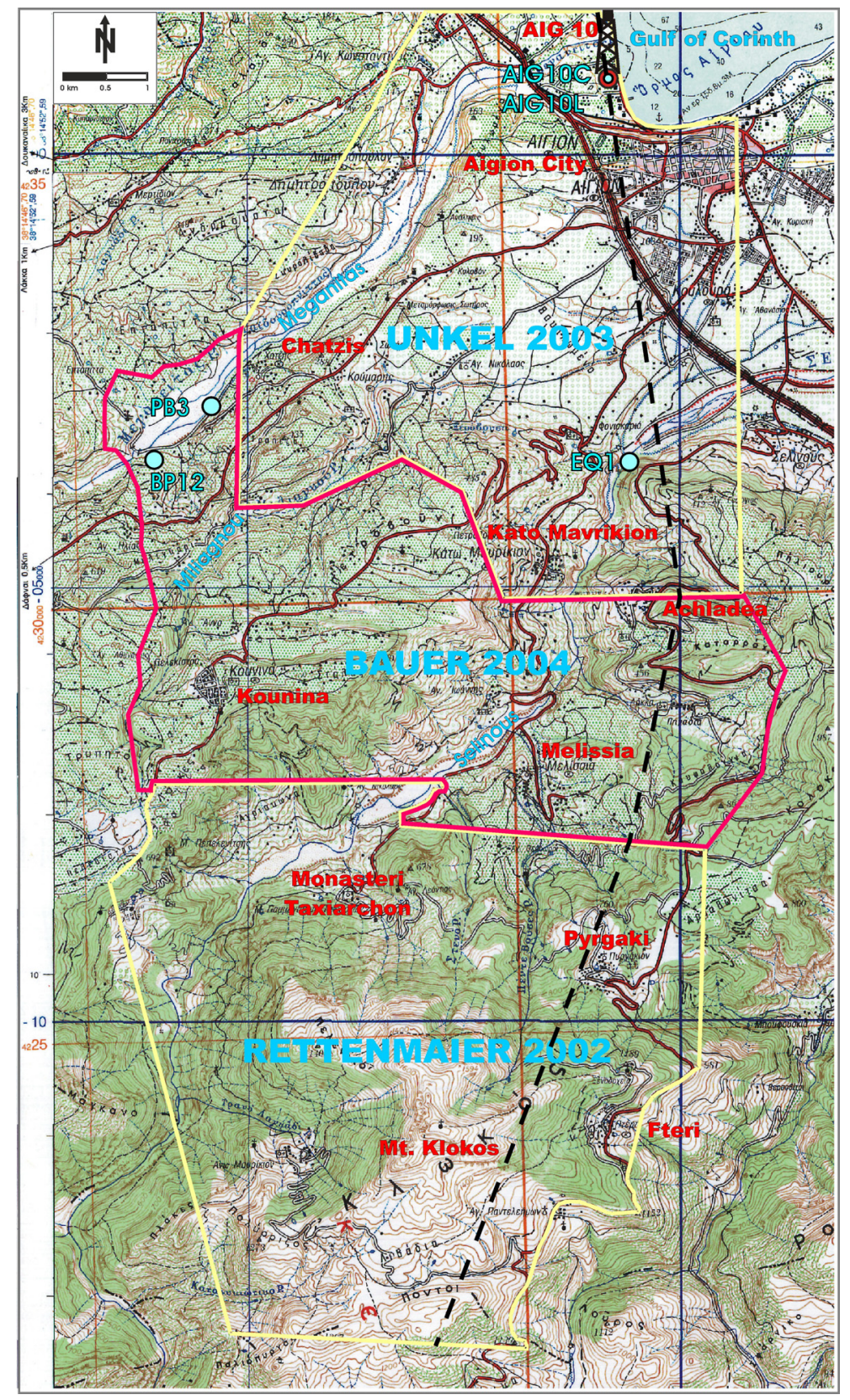

Fig. II.2: Overview of the study area. Based on the field studies and hydraulic tests a conceptual model was prepared which runs along the black dashed line and forms the basis for a numerical 2-D model.

In the northwest, the area is bordered by the Meganitas river valley and in the east by the Selinous river valley. Pilot investigations for the AIG10 drilling activities were done by Rettenmaier, 2002. In his diploma thesis Unkel, 2003 helped with the deep pumping tests in AIG10 and mapped the area of Aigion and the Eliki fault. Bauer, 2004 closes in his diploma thesis the gap between the two mapped areas and has performed additional pumping tests in the Meganitas valley.

Legend:

\section{AIG10: drill site}

AIG10C: hydraulic test in the conclomerates ( $240 \mathrm{~m}$ bsl);

AIG10L: hydraulic test in the platy limestones ( $710 \mathrm{~m} \mathrm{bsl);}$

PB3, BP12: location of Meganitas valley pumping tests;

EQ1: Selinous pumping test sites at the Eliki fault; 
The study area begins at the northern end of the harbor of Aigion (Gk. Alyiov) where the AIG10 borehole is located as well (Fig. II.2). In the west, the area is bordered by the Meganitas river (Gk. M $\varepsilon \gamma \alpha v \imath \tau \alpha \sigma$ ) to the southwest and the village Kounina (Gk. Kovvıva). It follows the Selinous valley (Gk. $\Sigma \varepsilon \lambda \lambda_{\mathrm{v}}$ ov $\delta \alpha \sigma$ ) up to the Klokos mountain area and the Ponti valley as the southern most point. To the east of Aigion the study area follows the highway and the main road in southerly direction through

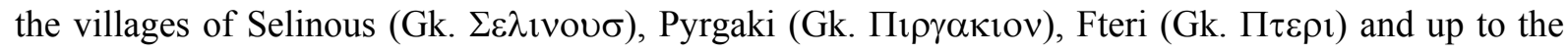
Ponti valley in the Klokos area (Fig. II.2).

The morphology of the study area is characterized by the extensional Corinth graben structure with step faults and tilted blocks (Fig. II.3) and is strong affected by the system of rivers and different rock resistivities (Fig. II.4). The northern part of Aigion and the location of the AIG10 borehole is dominated by river delta sediments of the Meganitas and Selinous in the east. The E-W striking Aigion fault produces a max. $150 \mathrm{~m}$ morphologic step and flat plains. Subdued relief dominates the ca. $200 \mathrm{~m}$ high adjacent area up to the Eliki fault step. Here the landuse is dominated by olive and lemon plantation and is affected by extreme groundwater exploitation (Unkel, 2003).

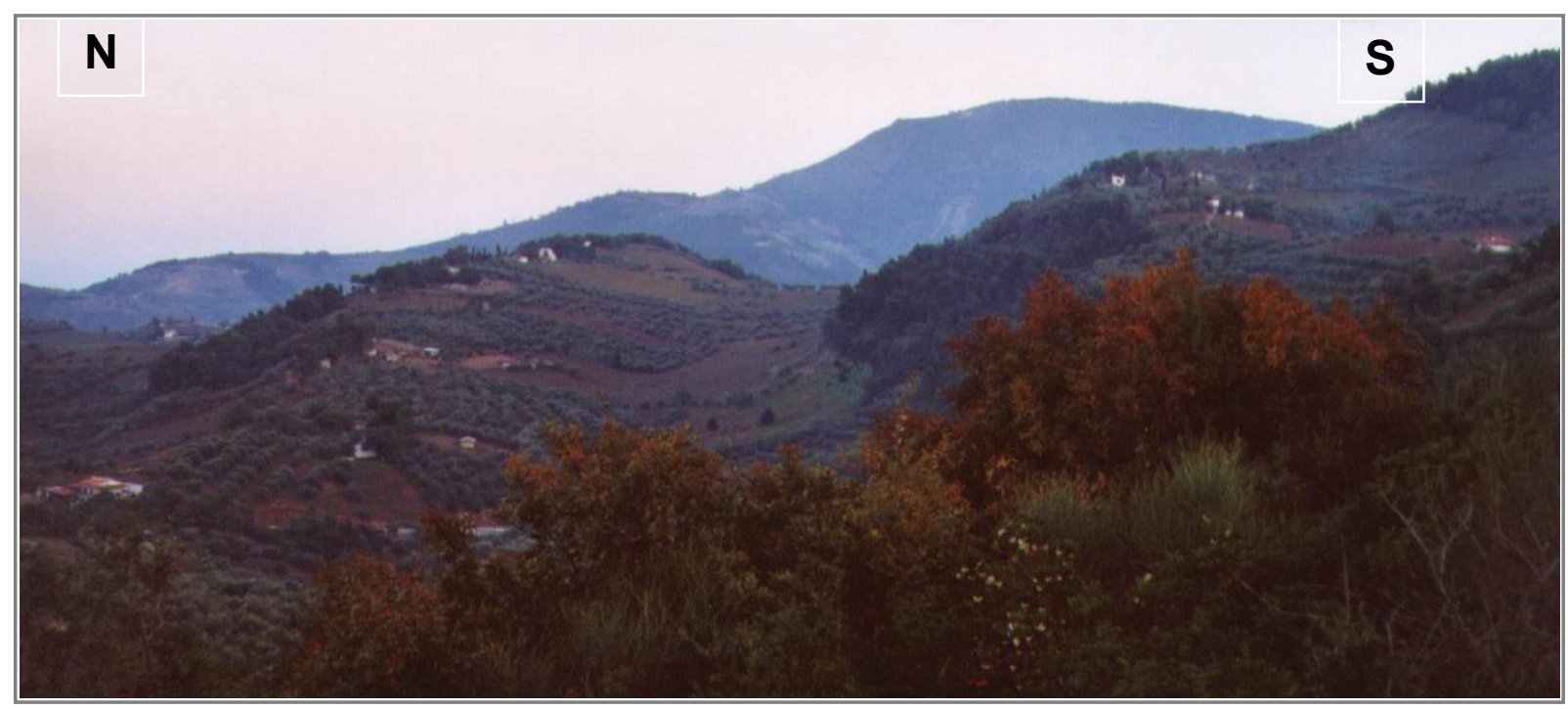

Fig. II.3: Tilted blocks of solid deposits of Gilbert-type delta conclomerates north of Kounina with fault steps and step by step displaced planes. The E-W striking of the faults is parallel to the Gulf (view in eastern direction).

The Eliki fault produces a step of up to $300 \mathrm{~m}$ and more and separates the northern plane from the low mountain range following to the south (Fig. II.4). The maximum elevation in this middle part of the

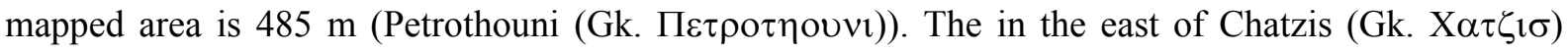
located Trapeza Mt. (451 m; engl. table) represents a table mountain of Gilbert-type delta conglomerates (Unkel, 2003). The underlying less competent marl layers causes mass movements and rock fall. Due to the fast opening of the graben, massive Delta Conglomerate deposits more than $500 \mathrm{~m}$ thick are typical for the northern part of the Peloponnesus (e.g. Poulimenos et al., 1993). 


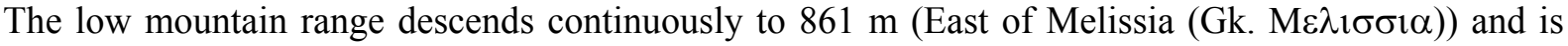
characterized by several E-W striking syn- and antithetic post alpidic normal faults, step faults and tilted blocks (Melissia-ft., Kerynia-ft. etc; Fig. IV.2). The rocks of the prevailing Olonos-Pindos Formation are much more competent and the Meganitas, Selinous and Miliagnou river valleys become deep canyons accompanied by massive mass movements as rock fall, rock sliding and mountain splitting (Fig. II.4). Very good expression of the block faulted hinterland gives the elevated plane north of Kounina (Gk. Kouviva) with several stepped planes (Fig. II.3). Due to the southern oriented planes and the softer conglomerates, marls and red soils winegrowing, fertilization, pest control and irrigation is dominating (Bauer 2004).

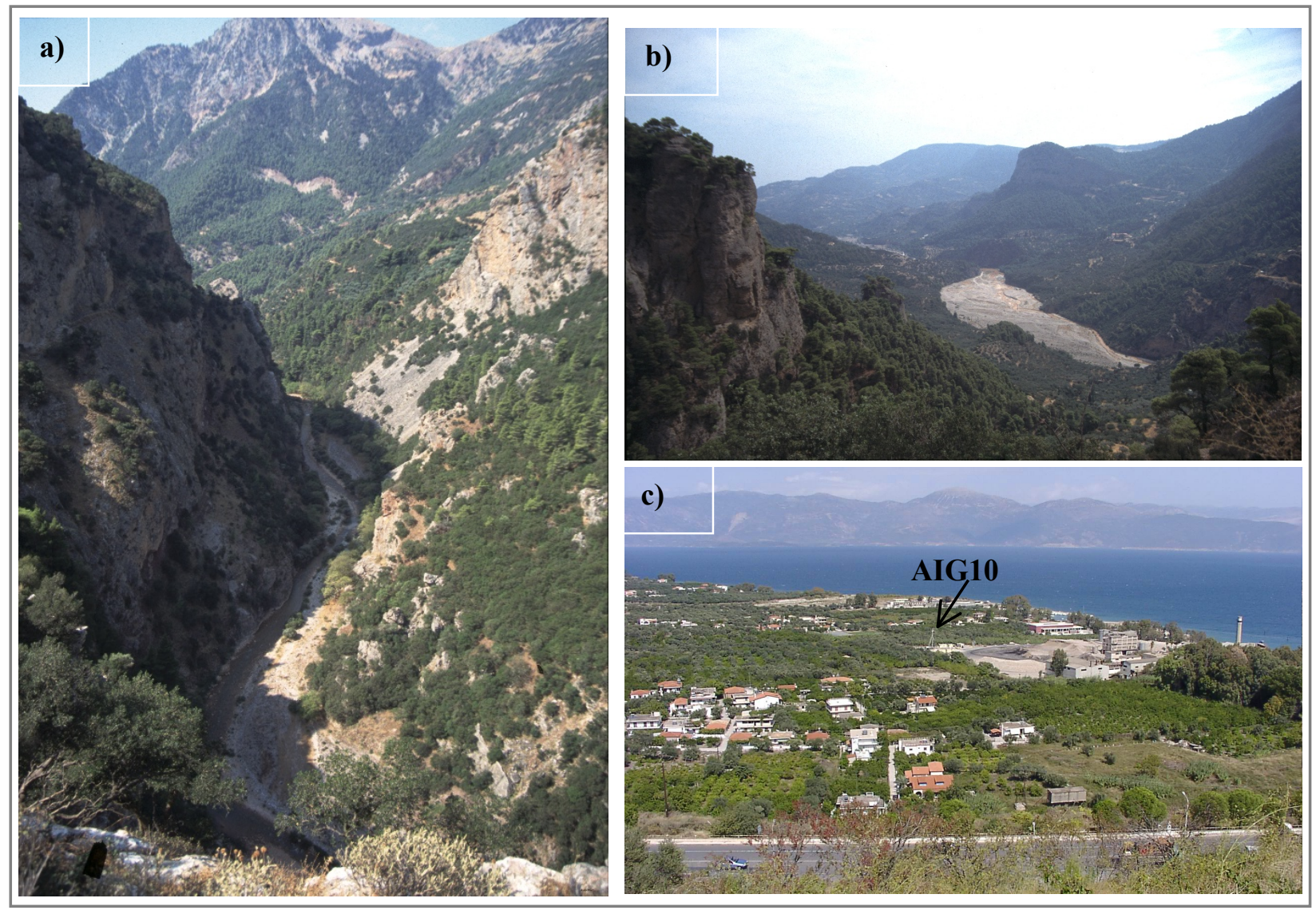

Fig. II.4 a-c: Strong relief is prevailing in the southern Achaia prefecture. The rivers produces narrow canyons when they follow in competent rocks a) Selinous river in Olonos-Pindos Limestones; b) step faulted hinterland of Aigion; in front right the first step of the Pyrgaki fault followed to the south by Kerynia-, Melissia-, and Eliki faults. c) the Aigion fault is representing the last onshore normal fault and is separating the harbor from the city. The $1000 \mathrm{~m}$ deep AIG10 borehole had the task to drill the fault plane at depth.

Very strong relief shows the southern part of the study area (Rettenmaier, 2002). The Pyrgaki fault runs through the village Pyrgaki and the Monastry Taxiarchon (Gk. M. T $\alpha \xi 1 \alpha \rho \chi \eta \circ v)$ and build with a displacement up to $950 \mathrm{~m}$ a marginal morphological step (Peleniko Mt. $1405 \mathrm{~m}$ ). To the west of the Peleniko the incised Selinous river has an altitude of $\sim 150 \mathrm{~m}$. This extreme relief of $1300 \mathrm{~m}$ is leading to strong mass movements up to gravitational mountain collapsing. The consequences are massive alluvial fans and delta fans from erosion, transportation and sedimentation (Fig. II.4 a,b). 
The maximum elevation of the study area is represented by the Klokos Mt. (1778 m) in the Klokos

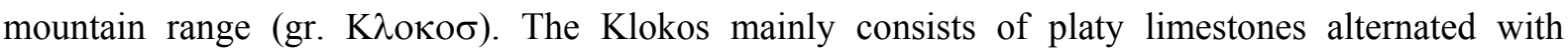
radiolarite due to tectonical thrusting (Rettenmaier, 2002). If one compares the tectonical structure with the physiography one can see clearly the correlation to the alpidic generated westward verging multiple imbricates and the postalpidic E-W striking normal faults (Rettenmaier et. al., 2004). Again, mass movements are represented in all scales. The Ponti valley and the Ponti normal fault (Fig. IV.16) represents the southernmost point of the study area with an displacement and morphological step of max. 400 m (Rettenmaier, 2002).

\section{II.2 Climate and meteorological aspects}

In Greece the Mediterranean climate generally prevails. On the Peloponnesus, mild winters and hot, dry summers are characteristic (Nikas, 2001b). The dry season begins in June and ends on the average in October. The temperature maxima are in the dry period around $26-33{ }^{\circ} \mathrm{C}$, the minima about $18-22$ ${ }^{\circ} \mathrm{C}$. The Achaia area is considered as the most rain-laden on the Peloponnesus. The steep mountain flanks along the coastline and the stepped blocks cause relief rainfall (Fig. II.5).

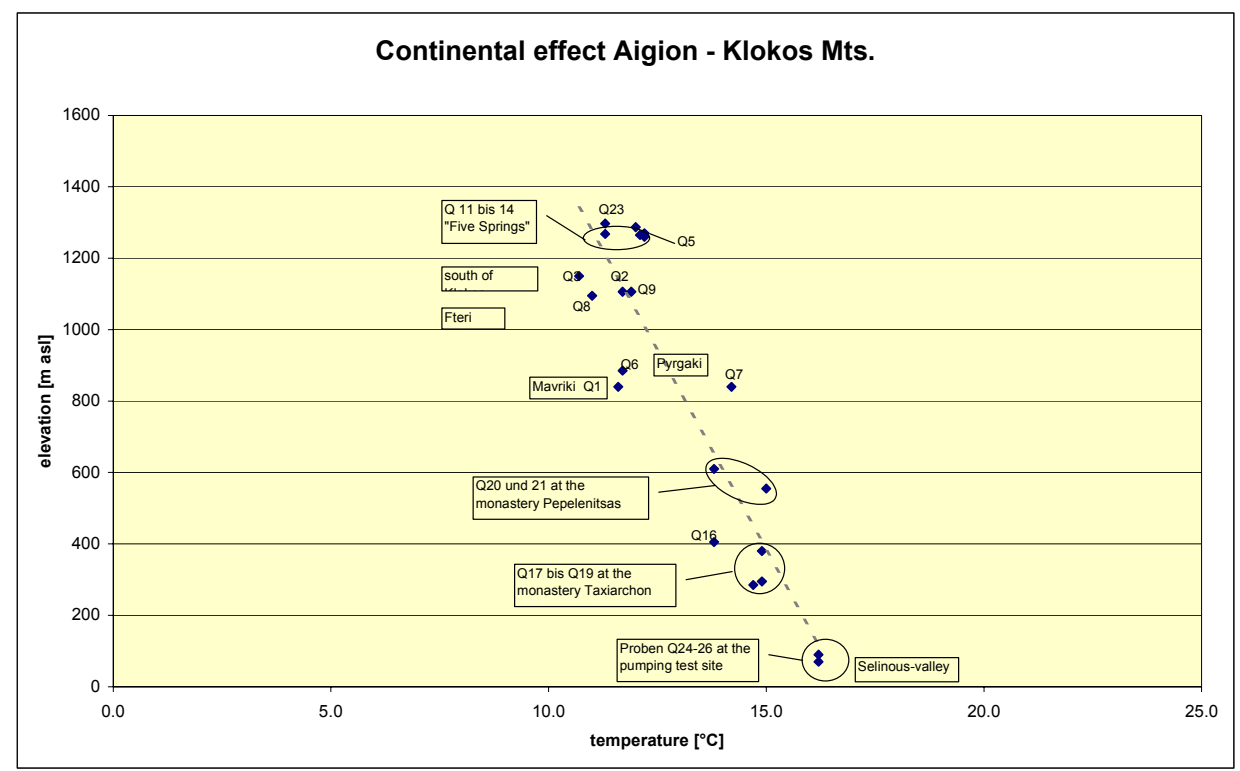

Fig. II.5: Temperature analysis of water samples at Aigion (north) and in the Klokos mountains (south). 


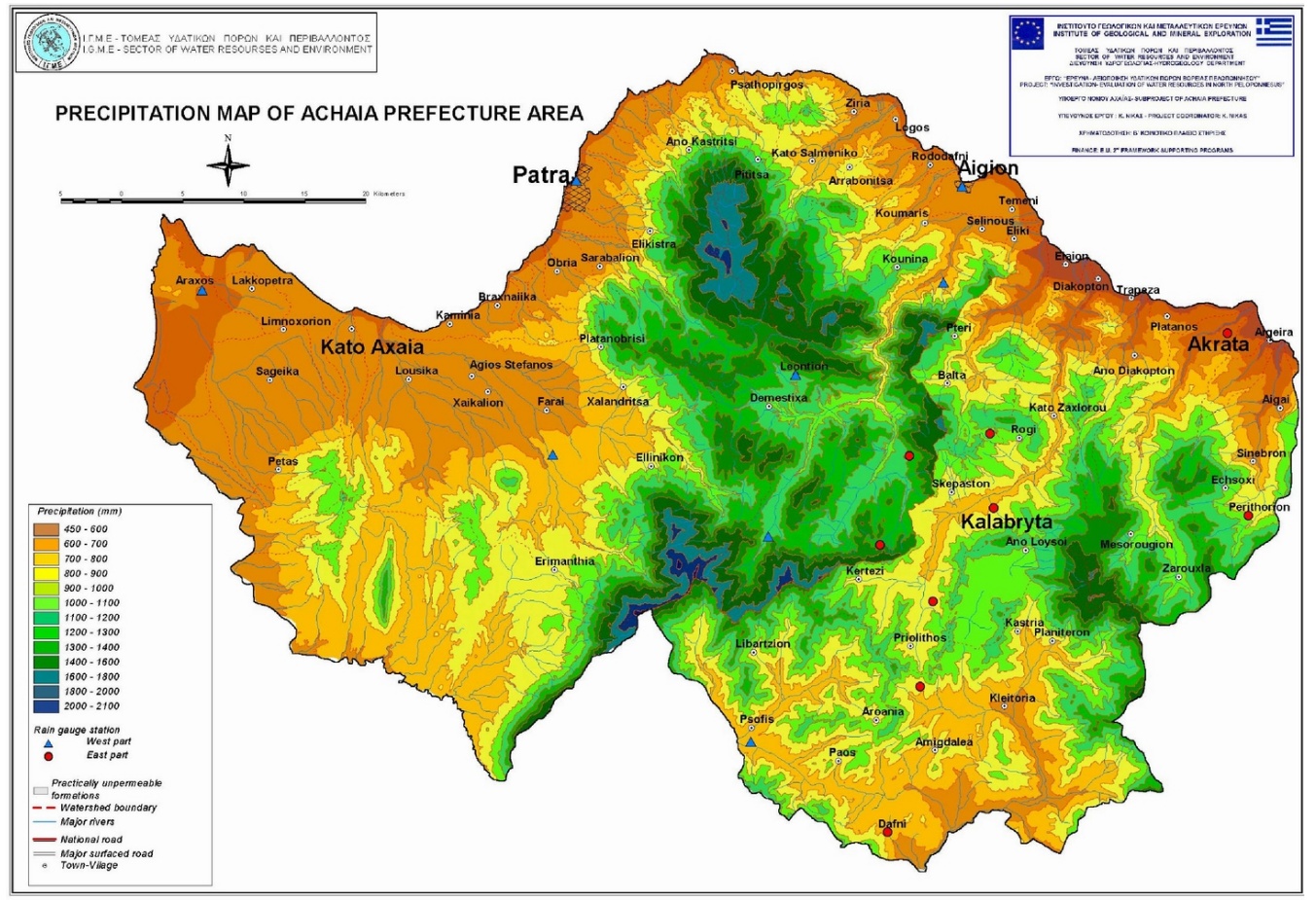

Fig. II.6: Precipitation map of the Achaia prefecture (after Nikas, 2001a, IGME Athens).

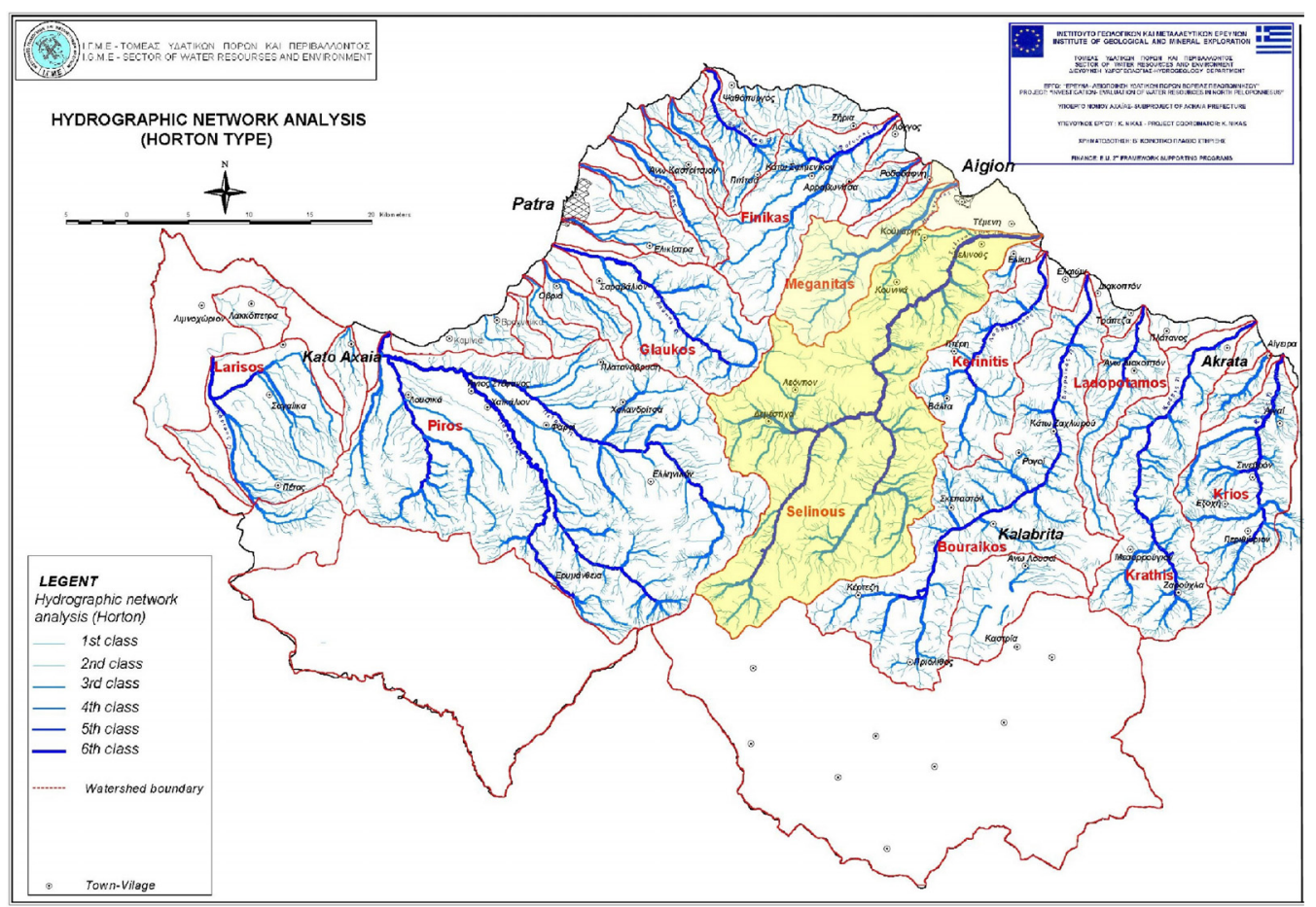

Fig. II.7: Hydrographic network of the Achaia prefecture (after Nikas, 2001a, IGME Athens, modified). The study area is hydraulically influenced mainly by the Selinous catchment areas whereas the AIG10 spud in point is located in the Meganitas river deltas. 
The rainy season is between November and February and the maximum and minimum temperatures are about 4 to $15^{\circ} \mathrm{C}$ (Tab. II.1). Frost and temperatures below zero are rare in the coastal range. In the higher mountains however snow can remain until April. During spring snowmelt let the rivers increase and leads to very strong erosion and surface run-off. Otherwise during summer the river channels can be complete desiccated and the groundwater withdrawals are very high. The growth period with temperatures from 14 to $22{ }^{\circ} \mathrm{C}$ last from March to May. The climate on the Peloponnesus can therefore be separated into three periods: dry season, rain season and growth period season (Fig. II.8).

Due to the morphology, precipitation is different in the vicinity of Aigion. The coastline is characterized by 450 to $700 \mathrm{~mm}$ average rainfall. Because of accumulation of clouds at the higher regions $2000 \mathrm{~mm}$ rain and more are possible, e.g. Klokos mountains east of Fteri in the mapping area (Fig. II.6). The average precipitation chosen for calibrating and controlling the hydrogeological conceptional model is $800 \mathrm{~mm}$. This number is calculated from the investigated surface and the catchment area of the Selinous and Meganitas valley (Fig. II.7).

Tab. II.1: Average values for temperature and precipitation in Patras.

\begin{tabular}{||l|c|c|c|c|c|c|c|c|c|c|c|c||}
\hline Temperatures $\left[{ }^{\circ} \mathrm{C}\right]$ & Jan & Feb & Mar & Apr & May & Jun & Jul & Aug & Sep & Oct & Nov & Dez \\
\hline monthly min temperature & 6.1 & 6.4 & 7.7 & 10.2 & 13.9 & 17.4 & 19.4 & 19.6 & 17.2 & 13.8 & 10.3 & 7.6 \\
\hline monthly average temperature & 10.0 & 10.6 & 12.5 & 15.6 & 20.1 & 24.1 & 26.4 & 26.7 & 23.5 & 19.0 & 14.5 & 11.4 \\
\hline monthly max temperature & 14.5 & 15.0 & 16.8 & 19.7 & 24.2 & 28.0 & 30.1 & 30.9 & 28.2 & 24.1 & 19.5 & 16.1 \\
\hline
\end{tabular}
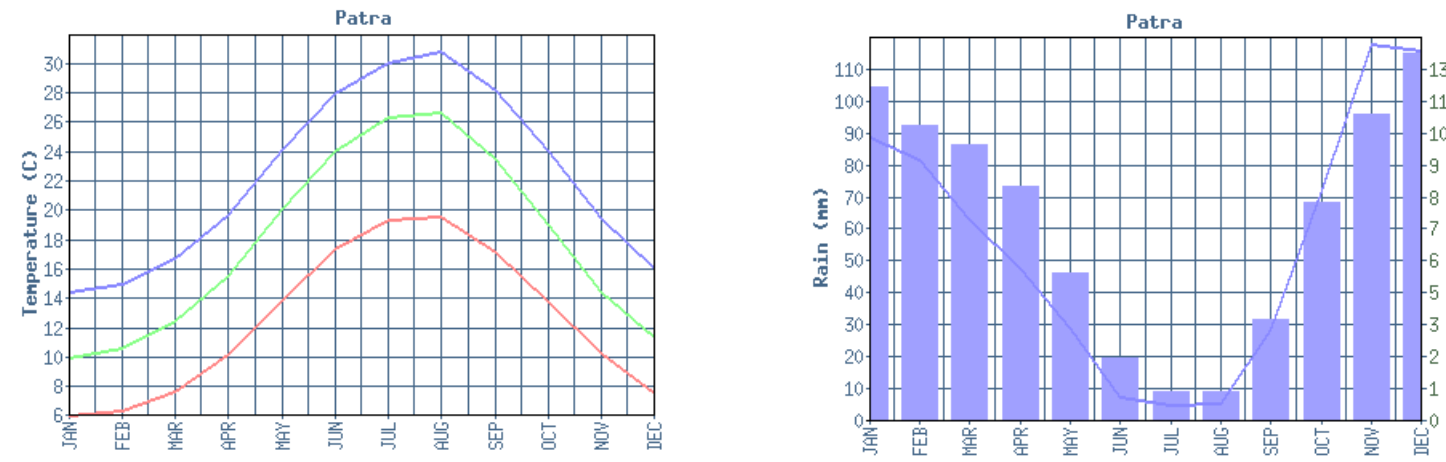

Fig. II.8: Annual temperature and precipitation of Patras; absolute Max. Temp.: 41,3oC / absolute Min. Temp.: 4,5oC ; Patra: Longtitude 21043'58" / Latitude 38015'0"/ Alt 3m ( Source: Hellenic National Meteorological Service HNMS; www.hnms.gr). 


\section{Geological - tectonical setting}

\section{III.1 Geological classification of Greece}

Nearly the entire Greek area belongs to the Alpidic Orogen of the Hellenides (Kober, 1929) (Fig. III.1) which is termed after the Greek part of the Dinaridic orogen after Suess, 1901. It extends from the north (Albania and Macedonia) over the Aegean islands in the SE and E up to the Rhodope massif of the Carpathians. From there, the Alpidic orogen continues to the $\mathrm{E}$ to the Himalayan mountains. The Jurassic-Tertiary orogens of the Mediterranean area are part of a large mountain belt, which originated from the Tethys oceanic system. Relicts of this oceanic system can be found north of Crete and the Hellenic trench where subduction is still going on. The Alpides as well as the Hellenides represent orogens, marking plate boundaries. The Hellenides are the result of the collision of the Apulian and Eurasian plate and their vergency usually corresponds to the direction of motion of the upper plate (Eisbacher, 1996, Schöneberg, 1997). The Hellenides are a supracrustal formation of primarily Mesozoic and Cenozoic sediments with mainly W and SW thrust direction and vergency. Additional senses of nappe movements have been discussed, e.g. Eurasian or Apulian vergent (Bonneau 1984, Coward et al., 1989, Robertson et al., 1991, Doutsos et al., 1993, and others).

Renz, 1940, and later Aubouin, 1959, made first classifications of the Hellenides due to sedimentary and magmatic facies and substantially due to tectonostratigraphic zones ("isopoc zones"). They differentiated four orogen phases from the Jurassic (Kimmeridgian Phase) up to the Miocene (Neo Hellenic Phase). Jacobshagen, 1978 and Richter, 1976 considered the accompanied flysch sedimentation while the prograding deformation of the Apulian plate and performed a nomenclature of nappes (Jacobshagen, 1980, Jacobshagen, 1986, Richter, 1993, Xypolias \& Doutsos, 2000). They classified the Greek area between the Foreland and the Hinterland into the Internal Hellenides (crystalline complex), West- and Central- Hellenides (Fig. III.1). The most authors agree that the orogeny took place in two phases (e.g. Jacobshagen, 1986, Doutsos et al., 1993): the Late Jurassic Early Cretaceous Eo-Hellenic phase with an west directed subduction and the closure of the Pindos Ocean at the western margin of the Tethys ocean, and the Meso-Hellenic phase in the Eocene/Oligocene and the closure of the Ambelakia Ocean (Jacobshagen et al., 1978, Doutsos et al., 1993, Degnan \& Robertson, 1998, Skourlis \& Doutsos, 2003).

\section{III.2 Geology of the northern Peloponnesus}

The study area near Aigion, including the location of the AIG10 borehole, is within a tectonical thrust sheet, termed the Olonos-Pindos Tectonic Formation (Central Hellenic nappe). According to the above mentioned classification, several thrust sheets are developed in the Peloponnesus reflecting five tectonic levels (Jacobshagen et al., 1976a, Eckl, 1979, Jacobshagen, 1986, Doutsos et al., 1993, Degnan \& Robertson, 1998, and references therein). The Foreland with the pre-Apulian Zone and the Plattenkalk series (after Jacobshagen et al., 1976a) is not outcropping in the Peloponnesus but on the islands Kefalonia and Zakynthos in the west (Fig. III.1). 


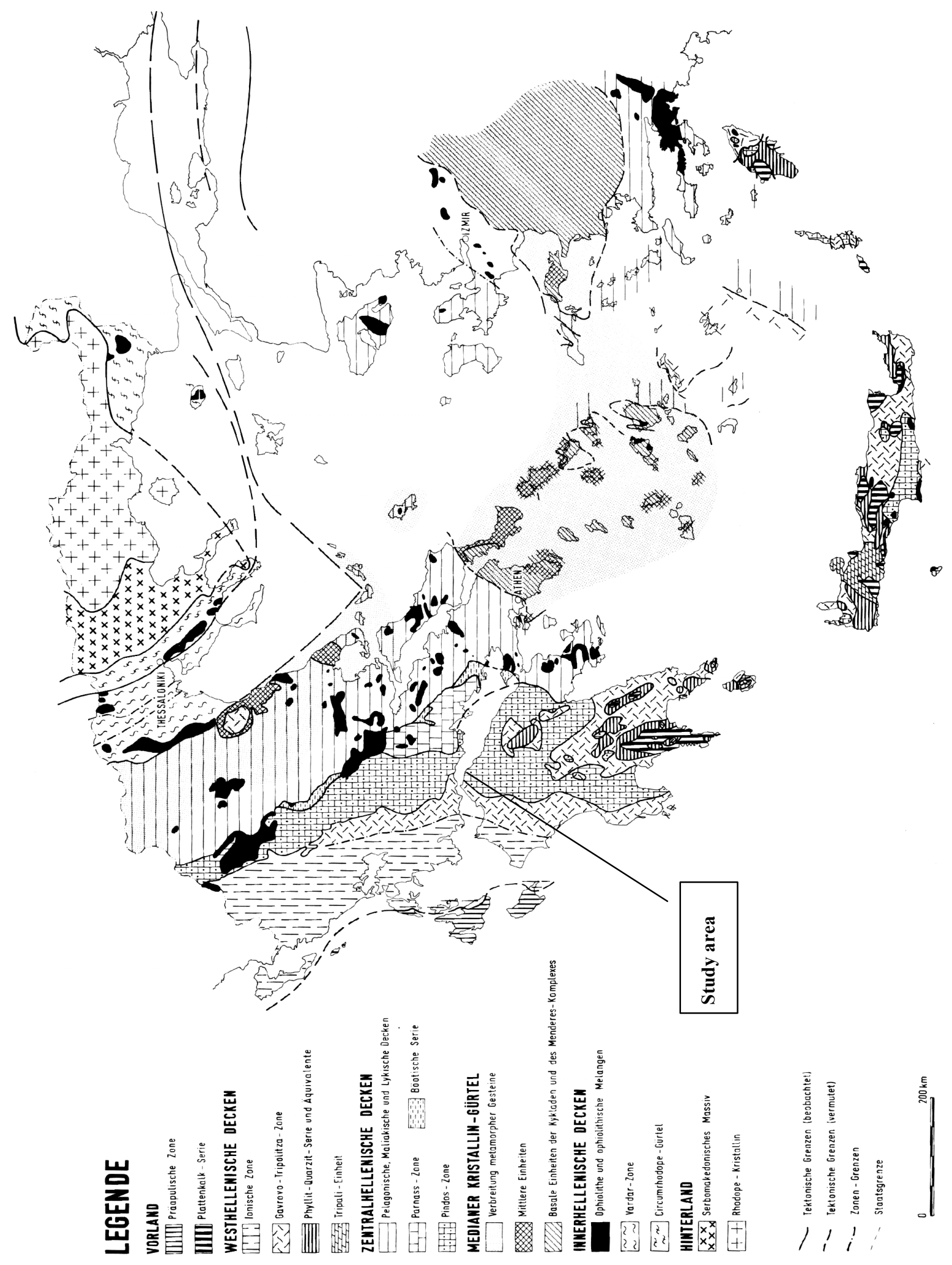

Fig. III.1: Geological-tectonical overview of Greece (modified after Jacobshagen et al., 1976a). 
To the east the West Hellenic Nappe including the Ionian series, Phyllite series and the Gavrovo Tripolitza zone builds the substratum for the Central Hellenic Nappes. The limestones of the Tripolitza Formation are ending in Flysch sediments which represents the top of the West Hellenic Nappe series. Directly above the Flysch sedimentation and partial direct on the Tripolitza limestones the OlonosPindos Tectonic Formation is following. The Olonos-Pindos Nappe represents the uppermost discrete tectonic unit of the Central Hellenic Nappe on the Peloponnesus with Middle Triassic up to Eocene sedimentary rocks (Aubouin, 1959, Dercourt, 1964, Kunz, 1976, Degnan \& Robertson, 1998, Neumann et al., 1996, Neumann, 2003).

The origin of the Tripolitza and Olonos-Pindos Tectonic Formations are the result of the Neo Hellenic orogenic phase from Oligocene/Miocene (Jacobshagen, 1976, Richter, 1976, Kowalczyk, 1977, Eckl, 1979). But tectonization of the Peloponnesus has already started in the Eo-Hellenic phase before Late Cretaceous. After evolutionary palinspastic models (Doutsos et al., 1993, Degnan \& Robertson, 1998, Neumann, 1998, Skourlis \& Doutsos, 2003) the Pindos Ocean was formed during Early Jurassic due to tectonic drift of the Apulian and Pelagonian microcontinent. In this emerging trough Mesozoic pelagic deep water carbonates, siliciclastics and silicious rocks (radiolarite) were accumulated on the passive continental margin of the Neo-Tethyan ocean basin. De Wever, 1994 has assumed a total length of the former basin of $800-1200 \mathrm{~km}$.

The closure of the Pindos ocean started during Middle Jurassic due to convergence of the northeastward migrating Apulian platform causing a SW-W oriented ocean-ocean subduction zone (Piper \& Pe-Piper, 1980). The consequence was the obduction of oceanic ophiolites and sediments onto the Pelagonian microcontinent. The thrusting resulted in syntectonical uplift and the formation of the "First Flysch" on the Apulian plate (Doutsos et al., 1993). The convergence of the Pelagonian- and Olympos microcontinents in the late Paleocene/Eocene led to the elimination of the Ambelakia Ocean and generated continental collision with tectonical uplift and the sedimentation of Eocene Flysch deposits.

The prograding eastward deformation then generated an E oriented subduction zone at the margin of the Apulian microplate accompanied with westwards directed thrusting. The following Miocene, Neo Hellenic Phase represents the main tectonic period according to the present geological tectonical structure of the Peloponnesus. In this phase the approximately $160 \mathrm{~km}$ wide Apulian passive continental margin was progressively shortened from $\mathrm{E}$ to $\mathrm{W}$ of about $6 \mathrm{~mm} / \mathrm{a}$ between the Early Oligocene and Late Eocene (Skourlis \& Doutsos, 2003). The displacement caused folding, thrusting, overthrusting with duplexes and multiple imbricates and a general crustal thickening of the Peloponnesus. By the Late Oligocene the movement of the Pindos Thrust nappe became inactive (Fleury, 1980) while post-orogen uplift is still ongoing, generating a highly elevated mountain chain accompanied with gravitational extension and erosion. There is still a scientific debate about the initiation and cause of the recent tectonical extension on the northern shore of the Peloponnesus and the opening of the Gulf of Corinth. Most authors presume a time gap between the final stage of the Alpine orogeny with immobilization of the Olonos-Pindos nappe and the beginning of extensional processes. They suppose Late Miocene age, whereas others assume that extension on the Peloponnesus has already started during the final stage of the Alpine orogeny in the Oligocene. The Holocene ongoing extensional process with strong seismic activity is, however, an incontrovertible fact. 


\section{III.3 Geodynamics in the Mediterranean area}

\section{III.3.1 Crustal deformation in the Mediterranean region}

Crustal deformation in the Mediterranean region has been discussed by many scientists since the pioneering studies of Mc Kenzie, 1972, Angelier et al., 1982, Jackson \& White 1989, Doutsos et al., 1987, 1988, 1993, and others. The Aegean Sea and the Gulf of Corinth in the eastern Mediterranean is an area of convergence of two main tectonic plates (Fig. III.2). Several microplates in-between provide a complex tectonic interplay between the Eurasian plate to the north and the African plate to the south. The Aegean area is located in the upper plate of the Hellenic subduction zone and subduction of the African plate is clearly expressed along the Hellenic Arc. The Macedonian microplate is located to the NW, whereas the Aegean itself is a part of the Anatolian plate.

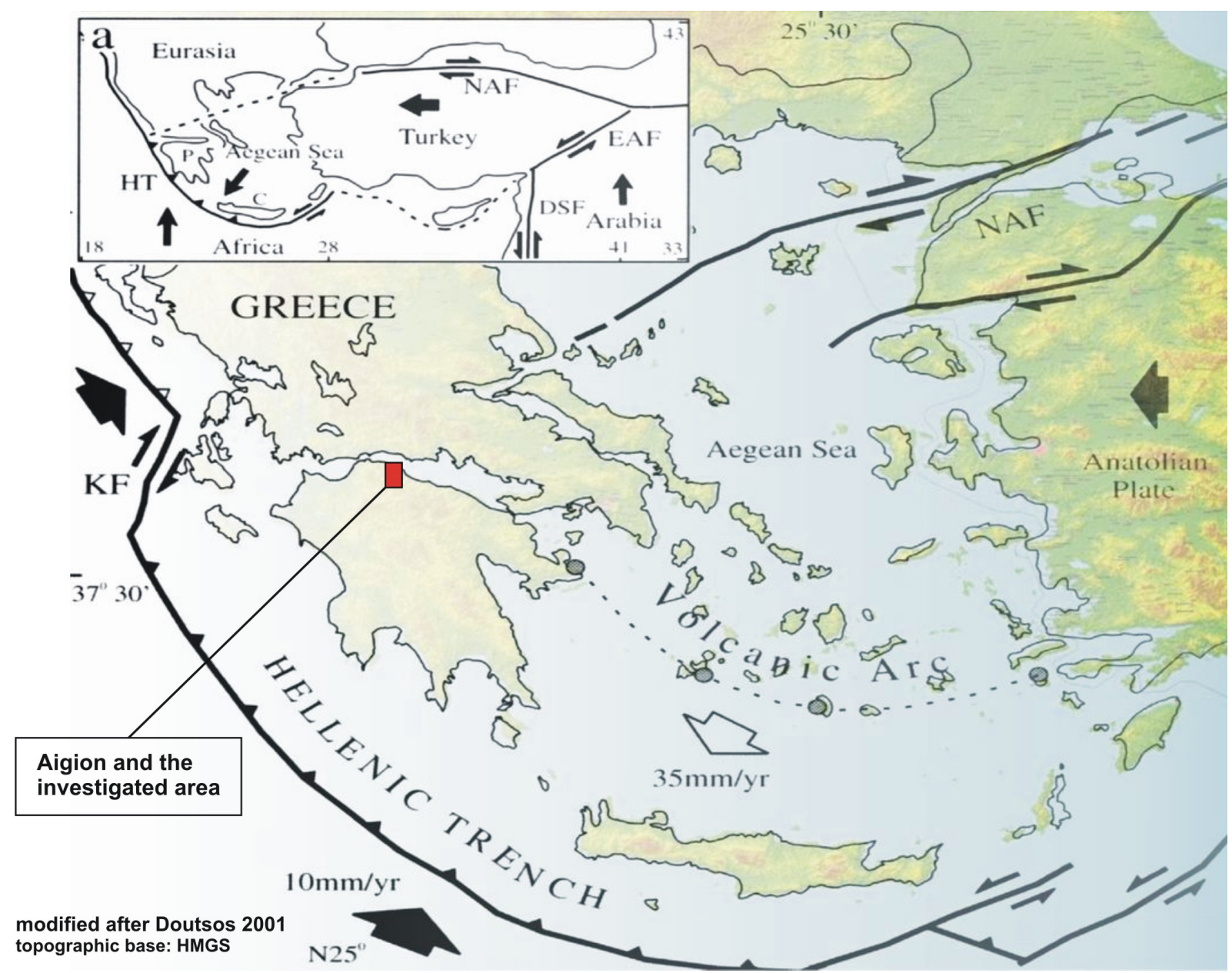

Fig. III.2: Tectonical overview and plate boundaries of the Aegean region. The red rectangle marks the study area of Aigion and the AIG10 borehole at the southern shoulder of the Gulf of Corinth. The Hellenic arc (HT) is bounding to the Kefalonia Transfer Fault (KF) to the west. Other abbreviations: NAF - North Anatolian Transform Fault; DSF - Dead Sea Fault; EAF - East Anatolian Transfer Fault; P - Peloponnesus; (modified after Doutsos, 2001). 
The northern boundary is the active dextral transfer fault of the westward moving Anatolian escape block (North Anatolian Fault NAF) due to northward motion and continental collision of the Arabian plate relative to the Eurasian plate from late Miocene times ( $10 \mathrm{Ma}$, Armijo et al. 1999), (Fig. III.2a). Westerly propagation of the NAF has an increased influence on the northern Aegean domain from Pliocene times ( 3Ma, Gautier et al., 1999). The westward motion of Anatolia is almost entirely accommodated by dextral shearing along the NAF at a velocity estimated at 17-22 mm/a (Westaway, 2002, Clarke et al., 1998) to 28-32 mm/a (Le Pichon et al., 1995).

The initiation of Aegean extension is still not clear but is described in several publications. Extension is calculated to $13 \mathrm{Ma}$ (e.g. Le Pichon \& Angelier, 1979) or $6 \mathrm{Ma}$ (Westaway, 2002). Others think extension have occurred since 16-15 Ma (Le Pichon et al., 1995, Armijo et al., 1996) or even 5 Ma (Jackson, 1994) whereas Gautier et al., 1999 has shown that an earlier age of $>21$ Ma is possible. Since the early 1970s, most geodynamic models proposed for the Eastern Mediterranean consider that the initiation of extension in the Aegean, during the late Middle Miocene or later, was a direct consequence of the westward extrusion of the Anatolia escape block (e.g. Brune, 1968, Jackson, 1994, Taymaz et al., 1991). Others have different explanations of "roll-back" theory and southward migration (retreat) of the Hellenic subduction surface trace (e.g. Le Pichon \& Angelier, 1979, Laigle et al., 2004). Investigations by global positioning system (GPS) indicate that, at present, the southern Aegean moves southwestward with respect to stabile Eurasia, at a velocity of about 32-35 mm/a (Fig. III.2) (e.g. Le Pichon et al., 1995, Kahle et al., 2000).

Wortel \& Spakman, 1992 show that since Late Miocene, the NW-striking convergent plate boundary and its associated arc and back-arc areas migrated towards the southwest in response to a strong slab pull, causing a retreat of the subducting plate (Le Pichon, 1979, Doutsos et al., 1988). Papazachos et al., 2000 used the locations of shallow earthquakes (1956-1995) to investigate the Wadati-Benioff zone geometry of the Hellenic arc. His results support the idea of roll-back but attributed the cause of extension due to gravitational spreading and collapse of the Aegean lithosphere. Active strain pattern by GPS measurement compared with the Oligo-Miocene finite strain field by Jolivet, 2001 as well provides evidence that gravitational collapse due to slab retreat is the primary cause for post-orogenic extension in the Aegean sea and Western Anatolia. Gautier et al., 1999 show on metamorphic complexes of the Aegean that regional-scale extension could be already strongly active in the Aegean area before the onset of Arabian indentation into Eurasia (Lower Miocene vs. Middle or Upper Miocene). Gautier et al., 1999 implies that the initiation of Aegean extension did not result from the lateral extrusion of Anatolia. Instead, extension has started because of gravity spreading of the continental lithosphere that had previously been thickened during Alpine collision.

However, the present southern boundary of the Aegean domain, the South Hellenic subduction zone, represents the free "edge", allowing the Aegean lithosphere to either spread or escape. If "Roll-back" of the subducting plate behind the volcanic arc (e. g. Milos, Santorin) causes retreat, it then would allow back-arc extension resulting in different extensional structures and concentration in several zones of opening grabens (Eisbacher, 1996). Although extension processes can be explained in the realm of continent-continent subduction along the Hellenic trench and are typical for back-arc regions, the specific conditions in the Gulf of Corinth seem to be complicated by additional forces. The Mediterranean sea floor is subducted beneath the western part of the Hellenic arc and dips at a gentle angle for about $200 \mathrm{~km}$ under the Peloponnesus (Hatzfeld, 1994). The Kefalonia transfer fault in the NW transfers the Hellenic Arc to the east onto the Greek mainland. Thereby continental crust is being 
subducted and convergence is transferred on the overriding plate and the Peloponnesus. NE- and WNW-striking tectonical grabens and rift structures are the result of this additional forces (Poulimenos, 1989, 1993). Beneath the Gulf of Corinth, a 100-km long part of the subducted slab steepens abruptly down to $150 \mathrm{~km}$. Originally, subduction along the Hellenic trench was characterized by penetration of a deep and steep slab into the asthenosphere and initiated probably in the Late Cretaceous with the African plate slow convergence $(1 \mathrm{~cm} /$ year $)$ towards the European plate. At present, faster movements ( $5 \mathrm{~cm} /$ year) of the southern Aegean towards Europe have been observed. It is supposed that the increase in total convergence rates between southern Aegean and Europe is responsible for the change in slab geometry and for the wide flat slab, occurring now beneath the Peloponnesus (Hatzfeld, 1994, Tiberi et al., 2000). Today the slab of the Hellenic subduction zone is continuous with depth beneath Crete and, hence, the process of southwestward migration of the convergent plate boundary yet may be operational. In contrast, the western plate boundary (the Peloponnesus) was clockwise rotated towards NNW and exhibits today a slab with a detached lower part. The beginning of this $25^{\circ}$-clockwise rotation about $5 \mathrm{Ma}$ ago caused an opening of major rift zones in the Aegean. Zelt et al., 2005 images the eastward subducting African slab beneath the western Gulf of Corinth at a depth of $74 \mathrm{~km}$ due to refraction and reflection traveltime analysis.

\section{III.3.2 Geodynamics of the Gulf of Corinth}

\section{Strong seismic activity}

The Gulf of Corinth is a tectonic half-graben developed by normal faulting in a extensional setting, separating the Peloponnesus from the mainland of Greece (Doutsos et al., 1987, 1988, Doutsos \& Piper, 1990). It is one of the most prominent seismic active rifts in the Aegean area, $120 \mathrm{~km}$ long and up to $30 \mathrm{~km}$ wide, with a WNW - ESE trend and a history of repeated large earthquakes of magnitudes $>6$ and high levels of background seismicity attributed to the extension processes (Fig. III.3). The study area at the south coast of the western Gulf of Corinth has experienced countless earthquakes, such as the Eliki event of 373 B.C. with the destruction of the ancient capital city Eliki, the Aigion event of Ms $\sim 7$ in 1861 or the M > 6 Aigion earthquake in 1995 (Steinwachs \& Henseleit, 1995).

\section{Extension rates}

Pleistocene faults (e.g. Dufaure, 1977, Jackson et al., 1982, Doutsos \& Piper 1990, Koukouvelas \& Doutsos 1996, Rettenmaier et al., 2004, and others), earthquake focal mechanisms and GPS measurements (e.g. Bernard et al., 1997, 2004, Clarke et al., 1998, Hatzfeld et al., 2000, Lyon-Caen et al., 2004, Pitilakis et al., 2004) indicate a regional N-S trending extension. The Corinth-Patras rift cuts more or less oblique the $\mathrm{W}-\mathrm{WNW}$ trending folds and thrusts of the Hellenic mountain belt. The present extension rate increases from $0.6 \mathrm{~cm} /$ year in the eastern Gulf of Corinth to $1.3 \mathrm{~cm} /$ year in the west near Aigion (Clarke et al., 1998), while 2 to $3 \mathrm{~cm} /$ year of dextral strike-slip occurs on the $\mathrm{N} 020^{\circ}$ trending Kefalonia Fault (Fig. III.2). This westward increasing extension led Le Pichon et al. (1995) to infer an anticlockwise rotation of the Peloponnese relative to mainland Greece, around a pole located in the Saronic Gulf. 


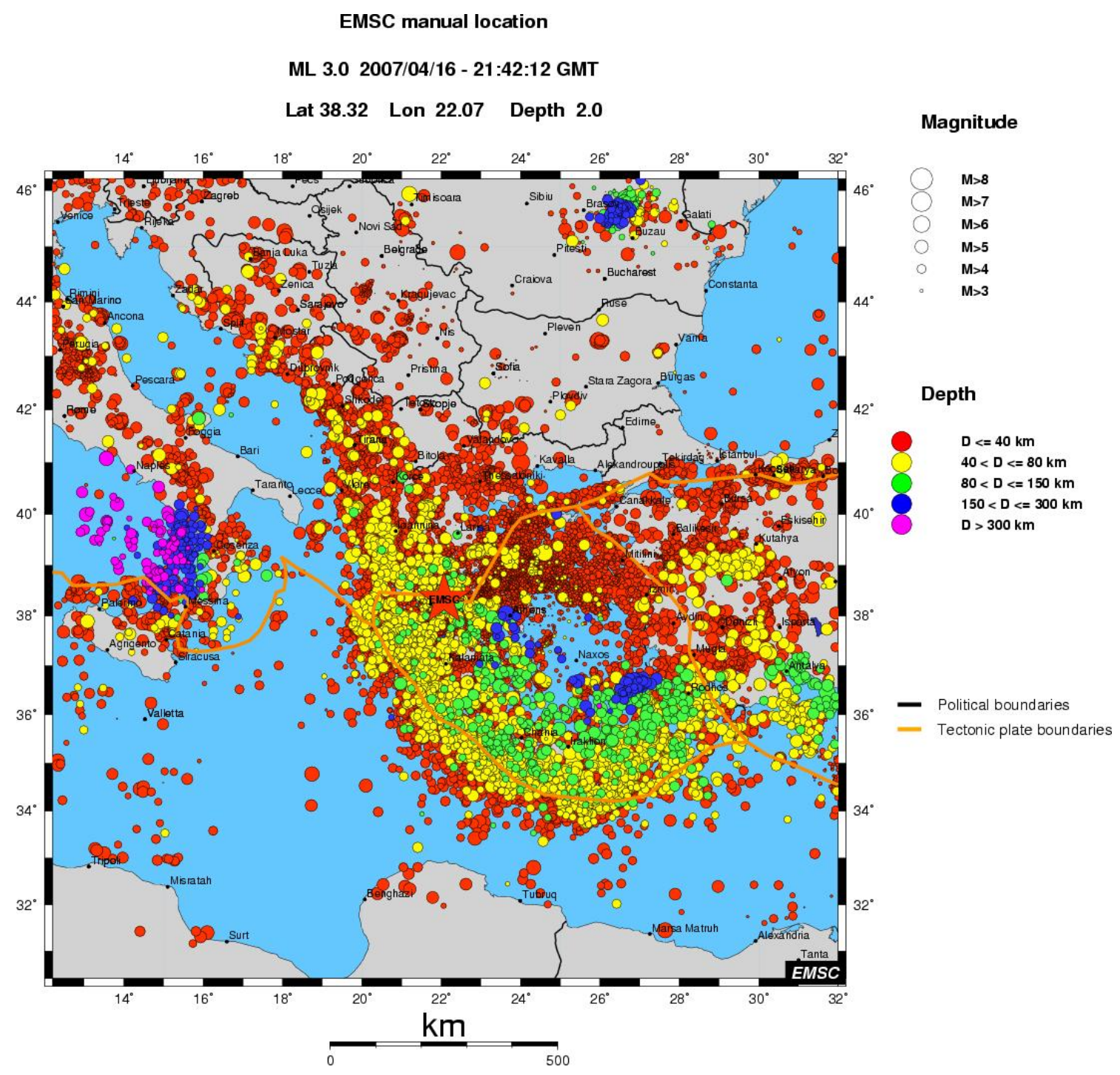

Fig. III.3: Historical Instrumental seismicity in the Mediterranean region from the European-Mediterranean Seismological Centre EMSC (source ISC catalog 1964-2002). The red asterisk represents an actual event and the location $31 \mathrm{~km}$ E of Patras and $8 \mathrm{~km} \mathrm{NW}$ of Aigion.

According to the most authors, predicted extension rates in N-S direction are at the upper limits of rates observed for comparable settings in the world. Ambraseys \& Jackson, 1997 showed from seismically-released strain in the region over the last 300 years that the earthquakes account for an average extension rate of about $11 \mathrm{~mm} / \mathrm{a}$ between the Peloponnesus and the island of Evia, of which about $10 \mathrm{~mm} / \mathrm{a}$ occurs in the Gulf of Corinth. Other geodetic studies (e.g. Billiris et al., 1991, Briole et al., 2000; Tselentis \& Makropoulos, 1986) have estimated the extension rate across the Gulf of Corinth as up to $15 \mathrm{~mm} / \mathrm{a}$. In contrast Westaway, 2002 estimated the max extension rate to $4 \mathrm{~mm} / \mathrm{a}$ based on uplifting calculations on normal faults. Clarke et al., 1997 indicates extension rates of $3+/-$ $1,2 \mathrm{~mm} / \mathrm{a}$ (western Gulf) and $4+/-1,6 \mathrm{~mm} / \mathrm{a}$ (eastern Gulf) by seismic moment summation. 


\section{Initiation and rift phases}

Extension probably started during late Miocene, with some uncertainty because of difficulties in dating of continental or lacustrine deposits due to the absence of fossils (e.g. Kowalczyk et al., 1977, Bentham et al., 1991, Collier \& Dart, 1991). As mentioned before the exact dating of initiation of Aegean extension is still not clear, either the Corinth rifting. However, much of the extension on the prominent E-W faults has occurred during the Quaternary (Doutsos \& Piper, 1990) and is continuing today. The WNW-striking grabens (Patras-Corinth-Rift, Megara basin) propagated westwards to the Ionian sea between Pliocene to Quaternary times. Between the stable Europe and the southern Aegean, undergoing extension, they might constitute a form of pull-apart basins (Doutsos, 2001).

After Doutsos et al., 1985 the tectonic development of the post middle Pliocene subsidence realm was geodynamically controlled by two different processes. First, the Patras graben was developed by reactivation of older NE-SW-striking tectonic elements in an area of updoming (thickening of the crust in the west), associated with the subduction of the pre-Apulian zone under the Peloponnesus. Second, the Corinth graben evolved, completely independent from older structures, by an extension in NNE direction. This extension includes the whole Aegean back-arc region and eastern mainland of Greece.

Ori, 1989 has described two distinct phases of "rift" opening, which gave rise to the depositions of the Neogene to Quaternary sediments. At the beginning of the first rifting phase (late Miocene(?) - early Pleistocene) isolated basins, bordered by faults, were the site of deposition of lacustrine-lagoonal sand, marls and clays, overlying thick alluvial conglomerates (Ghisetti et al., 2001).

The second rifting phase is characterized by the deposition of thick sequences of conglomerates. These delta conglomerates of the Gilbert-type required a higher subsidence rate than in the previous phase to generate such conglomerate bodies several hundred meters thick (Piper et al., 1990, Moretti et al., 2003). According to Ghisetti et al., 2001 the conglomerates overlay discordantly the faults of the first rifting phase, whereas later, newly formed faults (e. g. the Eliki Fault and Aigion fault) penetrated the Gilbert-type delta conglomerates. Geomorphological and stratigraphic evidence indicates that, at present, the faulting has migrated basinwards into the original hangingwalls, in several cases within the late Quaternary (Goldsworthy \& Jackson, 2001). They conclude that most of the morphology associated with the active coastal faults can be generated in less than 1 million years.

\section{Fault geometry and the question of symmetry}

The southern shoulder of the Gulf of Corinth is characterized by en echelon arranged major northdipping normal faults and south-dipping antithetic normal faults along its north coast (e.g. Jackson, 1982, Doutsos et al., 1993, Koukouvelas et al., 1999). Major earthquake activity occurs at depths between 3 and $24 \mathrm{~km}$, with a strong mode between 4 and $11 \mathrm{~km}$ depth below the southern rim of the graben system and the graben center (Fig. III.4). An $15^{\circ}$ dipping zone between 8 and $12 \mathrm{~km}$ has been observed in aftershock studies (e.g. 1995 Egion earthquake, Bernard et al., 1997) and microseismicity (Rigo, et al., 1996, Rietbrock et al., 1996) and dips of 30-35 ${ }^{\circ}$ resulted from fault plane solutions (Hatzfeld et al., 2000). The dip angle of the north-dipping normal faults is usually steep at the surface. In the area of Aigion e.g. the normal faults possesses dip angles mostly $>55^{\circ}$ (Rettenmaier, 2002, Unkel, 2003, Bauer, 2004, Rettenmaier et al., 2004). Hatzfeld et al., 2000 showed on microseismic studies that faulting occur on normal faults with the active plain dipping at least with $45^{\circ}$. In contrast to Ori, 1989, Armijo et al., 1996 and Doutsos, 1985 which have proposed that the rift 
formed in two stages and are controlled by steep normal faults $\left(50-60^{\circ} \mathrm{N}\right)$ Sorel, 2000 assume that fault kinematics indicate a single tectonic regime during all the rifting. He generated a profile from Helmos mountains to the North where he described a north dipping low-angle normal fault where the fault plane is being present at only 2,5 km depth beneath the northern coast of the Peloponnesus and where the other faults merge with progressive curvature into the detachment zone. They propose that it is an inactive north-dipping low-angle normal fault $\left(0^{\circ}\right.$ to $\left.30^{\circ} \mathrm{N}\right)$, called the northern Peloponnesus major fault (NPMF).

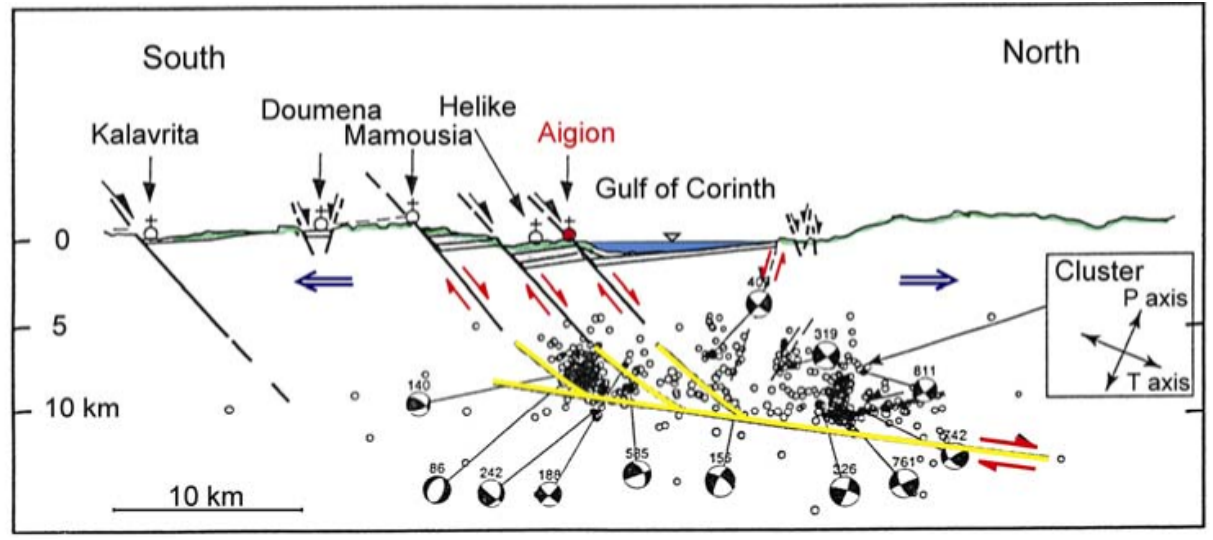

Fig. III.4: The seismogenic zone after Rigo et al., 1996. Major earthquake activity occurs at depths between 3 and $24 \mathrm{~km}$, with a strong mode between 4 and $11 \mathrm{~km}$ depth.

But steep faults could also abut against the flat-lying, seismically active detachment zone (Rigo et al., 1996) or, the $8-12 \mathrm{~km}$ deep seismic zone to the west is probably related to the seismic-aseismic transition and not to a possible almost horizontal active detachment fault (Hatzfeld et al., 2000.) Lowangle normal faulting is also mechanically difficult to initiate and requires strongly atypical crustal conditions (Westaway, 2002). Early studies proposed that the southern bounding faults forming the Gulf of Patras and the adjacent western Gulf of Corinth were listric and flattening northward under the Gulf of Corinth building an asymmetrical graben structure (e.g. Jackson et al., 1982, Doutsos et al., 1987, 1988, Melis et al., 1989, Doutsos \& Piper, 1990).

In resent studies different interpretations of the Gulf of Corinth as a simple half graben of major border faults dipping to the north on the southern graben shoulder and anithetic normal faults on the northern shoulder are discussed. Interpretations of seismic profiles by Moretti et al., 2003 show a simultaneous opening of the Gulf of Corinth bordered both north and south by active faults. They conclude that therefore the south-dipping faults cannot be considered as antithetic faults of the major north-dipping faults and that the general uplift of the Peloponnesus leads to the formation of new faults (Micarelli et al., 2003). Furthermore, on the basis of seismic lines across the Gulf of Corinth, Sachpazi et al., 2003 determined two distinguishable sedimentary units. The thickness of the lower unit increases to the north, whereas the upper unit has an increasing thickness towards the south. According to this, the major border fault was initially located on the northern graben shoulder, which switched after the deposition of the lower unit to the southern shoulder, leading to a symmetric graben. The geometrical connection between the steep outcropping faults and the seismogenic source of frequent earthquakes beneath the northern Peloponnesus is yet still not clear, and debate is going on. If the at the surface steep normal faults do merge onto a low angle shear zone, this could probably 
happens also below this seismogenic layer and is related to the rift stage, the building of a metamorphic core complex and the form of the Moho (Risch, 1976). Recent work has proposed that the overall form of the Gulf is the result of coupling between surface processes and flow of plastic lower continental crust (Westaway, 2002).

\section{Subsidence, uplift and where is the MOHO?}

Clement et al., 2004 document from reflection-refraction seismics interpretation that the Moho is at 40-km depth under the western end of the Gulf north of Aigion, rising to 32-km depth under the northern coast in the east of the Gulf which means a strong difference of $8 \mathrm{~km}$ in crustal thickness. The Moho topography showed highs and lows with a thicker crust to the west and which seems to be unexpected thick regarding to an area of extensional rifting process. Tiberi et al., 2001 showed on gravity inversion analysis $10 \mathrm{~km}$ crustal thickening in the western part and NW-SE-trending periodic crustal thinning of $4 \mathrm{~km}$ north of the Gulf of Corinth. These data are confirmed by Zelt et al., 2005 using 2-D inversion of refraction and reflection traveltimes. They imaged the Moho at $29 \mathrm{~km}$ depth in the east, dipping to $39 \mathrm{~km}$ in the west.

The southern Corinth graben shoulder and the Central Corinth rift is dominated by effects of subsidence with graben filling as well as by anomalous footwall uplift. Regional uplift is clearly documented by uplifted marine terraces (Armijo et al., 1996, Keraudren \& Sorel, 1987, Collier 1991, De Martini et al., 2004, Doutsos \& Koukouvelas, 2000) as well as by uplifted Gilbert-type delta conglomerates. At the southern shore of Aigion along normal faults the marine-continental terraces and Delta Conglomerates are often back tilted (Unkel, 2003, Bauer, 2004) and indicates uplift rates up to $\sim 1.5 \mathrm{~mm} / \mathrm{a}$ since Middle Pleistocene (Keraudren \& Sorel, 1987, Doutsos \& Piper, 1990, Westaway, 2002, Armijo et al., 1996, De Martini et al., 2004). Different causes for this anomalous footwall uplift are specified. Isostatic response (Le Pichon et al., 1995), crustal thickening (e.g. Pirazzoli et al., 1994), magmatism (Collier, 1992), or crustal thickening with westward inflow of lower crust (Armijo et al., 1996) are some of them. Westaway, 2002 suggested instead that the main effect is caused by the sediment loading and the unloading of the shore initiating southward lower-crustal flow beneath the Gulf driven by pressure variations at the base of the brittle layer. As a result of this rapid uplift the surface is being strongly incisted by rivers (in the study area e.g. Selinous, Meganitas). Perissoratis et al., 2000 estimates from seismic reflection images an average sedimentation rate of about $0,25 \mathrm{~mm} / \mathrm{a}$ and 850000 tons per year sediment influx. The subsequent erosion has resulted in depositions of up to $1 \mathrm{~km}$ of sediments in the Gulf (Brooks \& Ferentinos, 1984, Ferentinos, 1984, Higgs, 1988). Armijo et al., 1996 calculated $5 \mathrm{~km}$ thickness of Pleistocene sediment due to the observed uplift history in the footwall regions south of the Gulf, whereas Westaway, 2002 required no more than $1 \mathrm{~km}$ of sediment loading using a numerical model. Lemeille et al., 2004 differentiates sedimentation periods and estimated the sedimentation rates between 1.5 and $8.6 \mathrm{~mm} / \mathrm{a}$. Clément et al., 2004 have shown by the use of seismic reflection analysis at the base of the basin fill, that the thickness of sediment is at maximum $1.7 \mathrm{~km}$ and that it does not support the view that the subsidence of the basin was controlled by a single normal fault. Overall extension has thus occurred at an oblique strike to the axis of the Gulf with segmentation and is confirmed by several onshore studies; e.g. after Doutsos \& Poulimenos, 1992 rifted segments have subsided relative to the adjacent areas in N-Peloponnesus, but subsidence rates rarely exceed uplift rates. 


\section{Surface investigations}

\section{IV.1 Geology of the Aigion area and the AIG10 drill site}

The area near Aigion, including the location of the AIG10 borehole, is within the Olonos-Pindos tectonic Unit (Central Hellenic nappe), which is overthrusted on the Gavrovo-Tripolitza Unit, outcropping to the west (Fig. IV.1). In the east, the Pelagonic-Parnassos Unit is overthrusted on the Olonos-Pindos Formation. The generally prevailing westward propagation of the thrust nappes is confirmed by this investigations by the analysis of the tectonical structures in the hinterland of Aigion (Rettenmaier et al., 2004). Additionally, the southern Corinth graben shoulder in the vicinity of Aigion is characterized by morphological steps and fault escarpments up to several hundreds of meters. Extension is mainly accomplished by WNW-trending active faults with lengths onshore up to $25 \mathrm{~km}$ (e.g. Kelletat et al., 1976, Doutsos \& Poulimenos, 1992) and partly continuing offshore (e.g. Lykosius \& Sakellariou, 2001).

Most of these faults show an along-strike segmentation and often terminate against transfer faults. Five major faults are known to be most responsible for the historic and present seismic activities in the area of Aigion (Fig. IV.2) and a sixth normal fault "Ponti" is newly discovered within this work, $1.5 \mathrm{~km}$ to the south of the Klokos mountain and $4 \mathrm{~km}$ south of the Pyrgaki fault (Rettenmaier et al., 2002b). Thus, from the South to the North six major normal faults are present: Ponti-, Pyrgaki-, Melissia-, Kerynia, Eliki- and Aigion fault.

These E-W striking normal faults, related to the Miocene - Holocene rifting of the Golf of Corinth are younger than the tectonical structures of the Alpine orogeny. The orogenic overthrusting within the Olonos-Pindos Formations is very pronounced and is frequently leading to multiple imbrication and stratigraphic repetitions. These repetitions were additionally block-faulted by the neotectonics of the Corinth Rift, especially within the first $20 \mathrm{~km}$ to the south of Aigion (Rettenmaier, 2002, Rettenmaier et al., 2004).

The most active faults today are along the coast or offshore (e.g. Goldsworthy \& Jackson, 2001). During a 1995 earthquake, motion could also have occurred at the surface on the Aigion fault and extensive scarp development occurred in the Alluvium (Fig. IV.3). Otherwise, Ferentinos et al., 1985 showed on underwater studies that these scarps relate to slumping of unconsolidated fan delta deposits triggered by seismic ground motion. According to e.g. Bernard et al., 1997, the epicentre of the 1995 Aigion earthquake was instead located near the north coast of the Gulf opposite of Aigion. Between Aigion and Diakofto another damaging earthquake in 1861 caused fissuring and coastal subsidence along the Eliki fault (Lekkas et al., 1998, Koukouvelas, 1998, Koukouvelas et al., 2001).

The coastal normal faults are strongly influences the landscape, morphology, and rivers and control the Plio-Pleistocene sedimentation in the area. The footwalls of the coastal faults contain Gilbert-type delta deposits, with continuous foresets reaching elevations up to $1000 \mathrm{~m}$ above the sea level. They comprises often back-tilted south-dipping topsets (Rettenmaier et al., 2002a). Segmentation of the faulting is the principal control on the location of the largest fan delta systems as well as the uplifted terrestrial and marine terraces. 


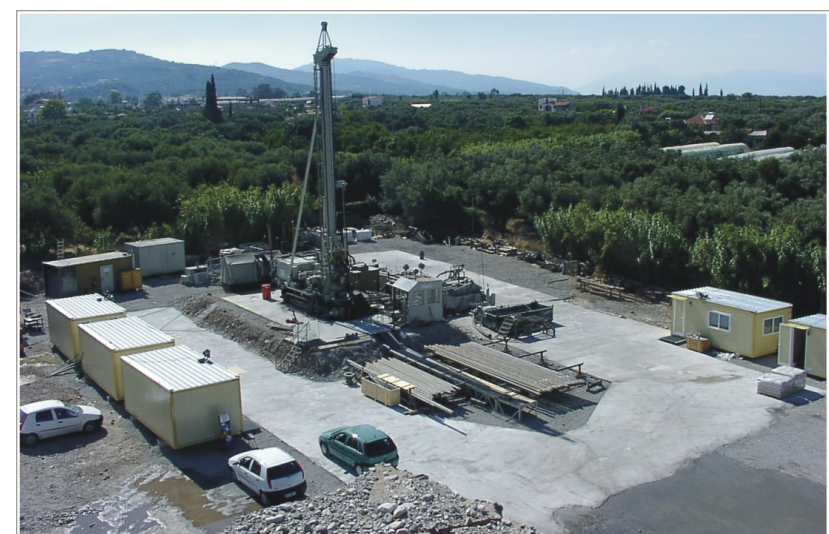

a)

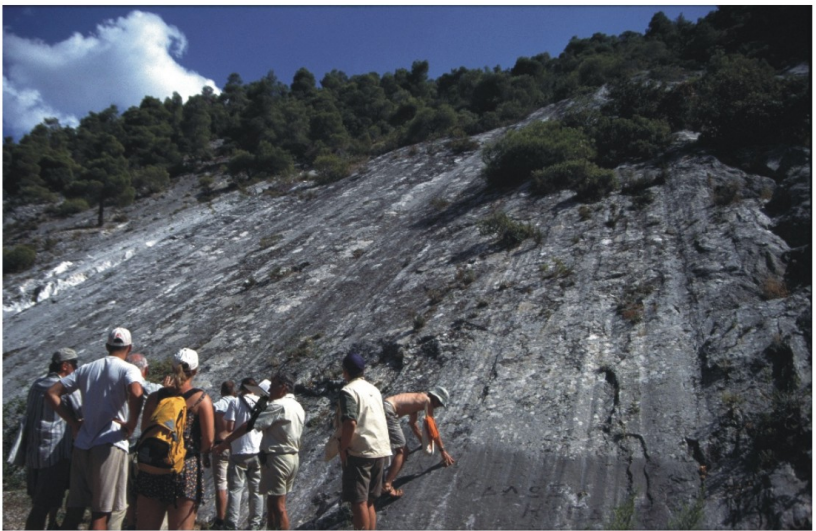

b)

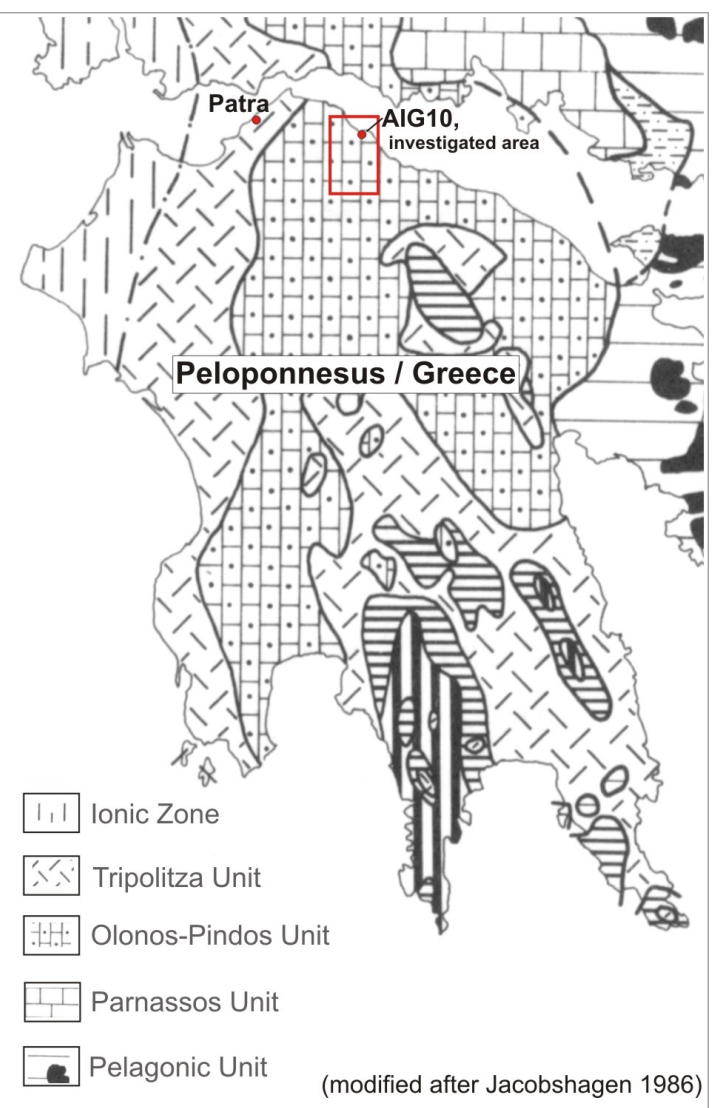

c)

Fig. IV.1: Geological-tectonical overview of the Aigion area and AIG 10 drill site. a): The drill rig for the AIG10 borehole located near the harbor of Aigion. The aim of the drill activity and choice of spud in point was to intersect the Aigion normal fault at depth in between the Olonos-Pindos platy limestones and not in the Corinth graben fill. b): The larger Aigion area is characterized by syn- and antithetic normal faults, (here Eliki fault) which are responsible for strong recent seismic activities. c): As a result of the Alpine orogeny the Peloponnesus peninsula can be separated into several tectonic thrust nappes. The rectangle marks the $80 \mathrm{~km}^{2}$ study area and the AIG10 borehole within the Olonos-Pindos tectonic Formation (Jacobshagen, 1986, modified).

The spud-in point of the AIG10 borehole in the harbor of Aigion is onshore in between the Meganitas river delta and the Alluvium. At depth the borehole intersect the graben sediments and then is calculated to hit the basement rocks resp. Olonos-Pindos Formation. The stratigraphic sequence and tectonical structure of the Formation is exposed in the hinterland of Aigion and the study for drill pilot investigations was one of the important parts of this work. The location of AIG10 spud-in point is chosen to drill the 1995 seismic active Aigion fault plane at depth in between the Olonos- Pindos Formation. 


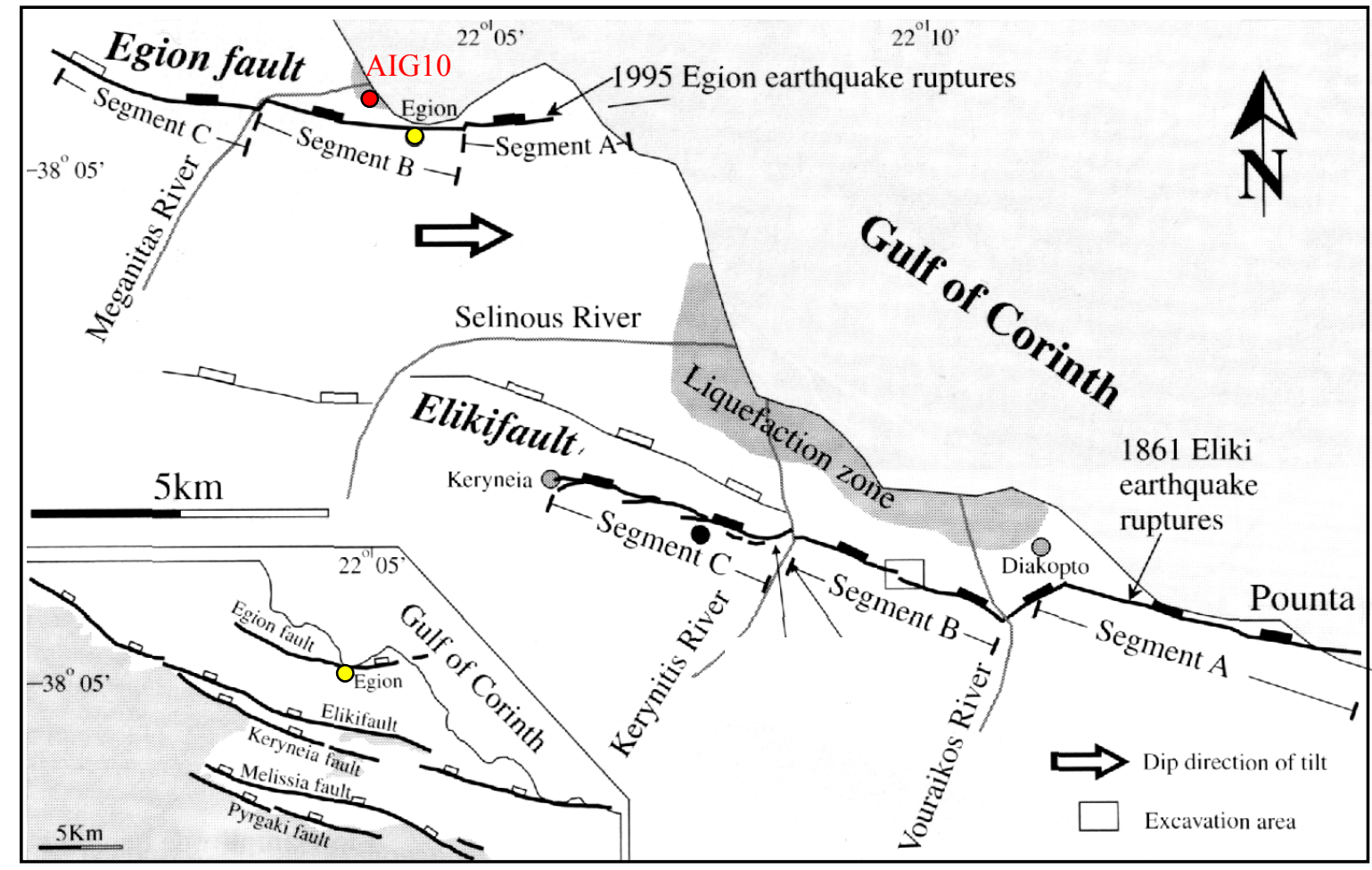

Fig. IV.2: Simplified geological-tectonical map and overview showing five major segmented normal faults in the Aigion vicinity (modified after Koukouvelas, 1996). (red dot: AIG10 spud in point; yellow: Aigion city).

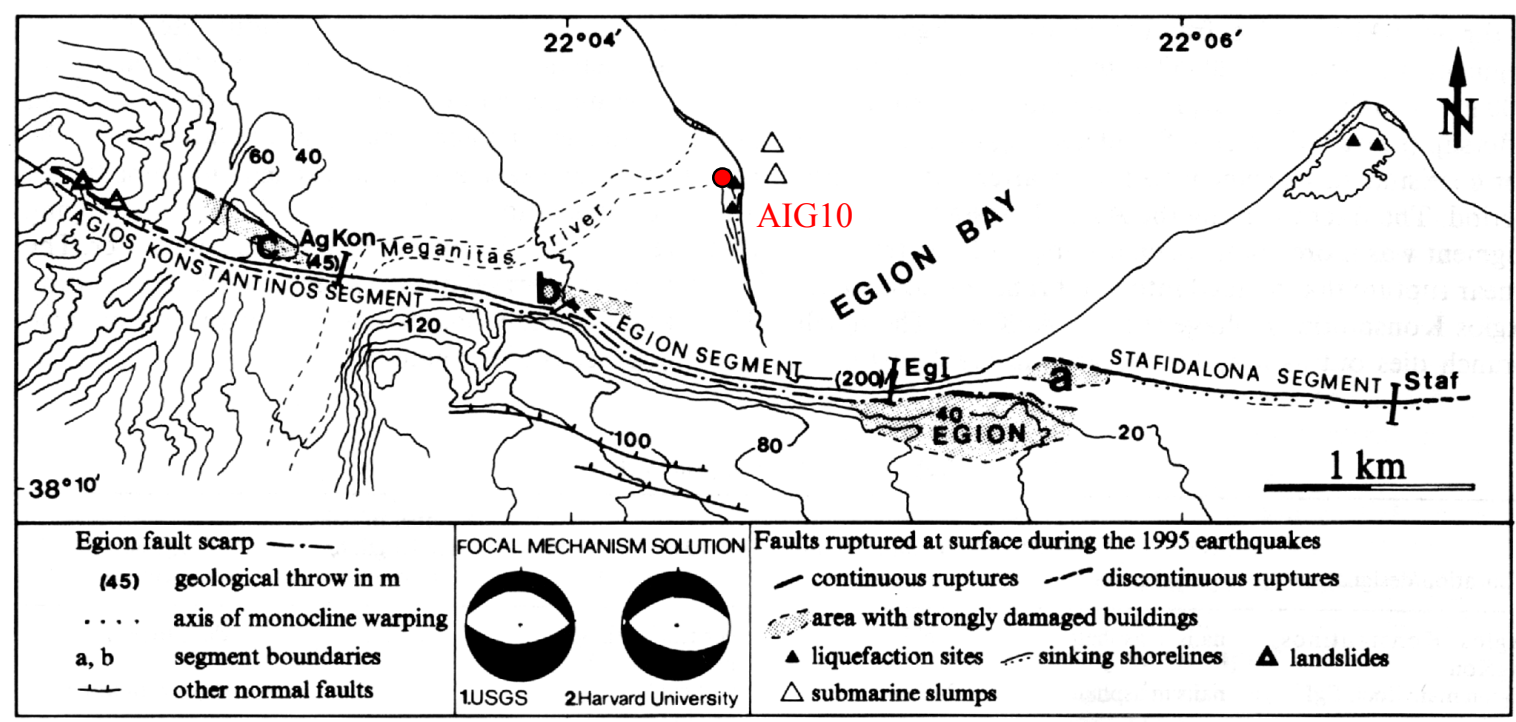

Fig. IV.3: Faults ruptured at surface during the 1995 earthquake on the segmented Aigion fault. The solution of the focal mechanism show normal faulting with a slightly oblique tendency (Koukouvelas, 1996, modified). 


\section{IV.2 Lithology of the Olonos-Pindos thrust nappe}

\section{IV.2.1 Overview}

A widespread area of the Peloponnesus peninsula belongs to the upper Olonos-Pindos Thrust Nappe (Fig. IV.1) and the mainly pelagic sediments of the zone were described and analyzed in details by Renz, 1940, 1955 in former studies and later on by Aubouin et al., 1970, 1977, Dercourt et al., 1973 and Fleury, 1980. More recent stratigraphical and sedimentological works were done by Neumann et al., 1996 for a southern part of the Peloponnesus peninsula and in general by Degnan \& Robertson, 1998. Tab. IV.1 show a comparison of the different stratigraphical classifications which provide the classification base used in this work, whereas a stratigraphical classification of the study area itself is not available. Furthermore, for more details in environmental classification and age determination for the sequences outcropping in the mapped area the publication of Degnan \& Robertson, 1998 were adducted in analogy of lithology.

Tab. IV.1: Stratigraphical overview of the Olonos-Pindos Formation modified after Degnan \& Robertson, 1998. The classification used in this study is based on the mentioned authors and is related to field work in the study area, additionally extended in consideration of works by Richter, 1976, Richter \& Müller, 1993, and Neumann et al., 1996.

\begin{tabular}{|c|c|c|c|c|c|c|c|c|}
\hline & & Aubouin 1959 & $\begin{array}{c}\text { Dercourt et al. } 1973 \\
\text { Fleury } 1980\end{array}$ & \multicolumn{3}{|c|}{ Degnan \& Robertson 1998} & \multicolumn{2}{|c|}{$\begin{array}{l}\text { Rettenmaier } \\
\text { this study }\end{array}$} \\
\hline \multicolumn{2}{|c|}{ Quart. } & \multirow{3}{*}{\multicolumn{5}{|c|}{ Post-Alpidic deposits }} & \multirow{3}{*}{$\begin{array}{l}\text { Post-Alpidic } \\
\text { Units }\end{array}$} & \begin{tabular}{|l|l} 
fluviatile deposits, soil, talus deposits, Alluvium \\
\end{tabular} \\
\hline \multirow{3}{*}{ : } & $\mathbf{P}$ & & & & & & & \begin{tabular}{|c|} 
"Gilbert-Type" Delta-Conglomerates \\
lacustrine-lagoonal-marine deposits \\
\end{tabular} \\
\hline & $\mathbf{M}$ & & & & & & & \\
\hline & $\begin{array}{l}\mathbf{E} \\
\mathbf{P}\end{array}$ & \multicolumn{2}{|c|}{ Flysch du Pinde } & \multirow{2}{*}{\multicolumn{3}{|c|}{ Pindos Flysch Fm }} & $\begin{array}{l}\text { Pindos Flysch } \\
\text { Formation }\end{array}$ & $\begin{array}{c}\text { Flysch-Series } \\
\text { turbididic sandstone } \\
\text { hemipelagical sediments (transition zone) }\end{array}$ \\
\hline \multirow{3}{*}{ 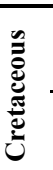 } & & \multicolumn{2}{|c|}{ Couches de Passage } & & & & \multirow{3}{*}{$\begin{array}{c}\text { Olonos-Pindos Platy Limestone } \\
\text { Formation }\end{array}$} & Silicious-Clastic-Limestone-Series \\
\hline & $\mathbf{U}$ & Calcaires & n Plaquettes & \multicolumn{2}{|c|}{$\begin{array}{l}\text { Kataraktis Passage Mbr } \\
\text { Erymanthos Lst Mbr } \\
\text { Klitoria Sst Mbr } \\
\end{array}$} & \multirow{2}{*}{ Lambia Fm } & & $\begin{array}{l}\text { Platy-Limestone-Series } \\
\text { very well bedded platy limestones }\end{array}$ \\
\hline & $\mathbf{L}$ & Premier Flysch de Pinde & Marnes Rouges & Paos & t Mbr & & & \begin{tabular}{|c} 
Calcarenit-Series \\
pink sequence of micrit, calcarenite, marlstones
\end{tabular} \\
\hline \multirow{3}{*}{ 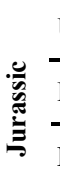 } & $\mathbf{U}$ & \multirow[b]{2}{*}{$\begin{array}{l}\text { Les Jaspes } \\
\text { a Radiolarites }\end{array}$} & Calcaires á Calpionelles & \multirow[b]{2}{*}{$\begin{array}{c}\text { Kakotari } \\
\text { Mbr }\end{array}$} & \multirow{2}{*}{$\begin{array}{c}\text { Aronia } \\
\text { Chert Mbr }\end{array}$} & \multirow[b]{2}{*}{ Lesteena Fm } & \multirow[b]{2}{*}{$\begin{array}{l}\text { Olonos-Pindos Radiolarite } \\
\text { Formation }\end{array}$} & \multirow{2}{*}{$\begin{array}{c}\text { Radiolarite-Series } \\
\text { red banded radiolarite, } \\
\text { interlayered with marlstone, micritic limestone, } \\
\text { or black chert (hornstone); } \\
\text { often reddish mudstone and shale }\end{array}$} \\
\hline & $\mathbf{M}$ & & $\begin{array}{l}\text { Radiolarites } \\
\text { Pelites de Kasteli }\end{array}$ & & & & & \\
\hline & \multirow{3}{*}{$\mathbf{U}$} & \multirow{3}{*}{$\begin{array}{l}\text { Les Jaspes et } \\
\text { Calcaires à Halobia }\end{array}$} & & \multirow{2}{*}{\multicolumn{4}{|c|}{$\begin{array}{c}\text { Drimos } \\
\text { Formation }\end{array}$}} & \\
\hline \multirow{2}{*}{ 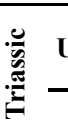 } & & & Calcaires de Drimos & & & & & (not outcropping in the investigated area) \\
\hline & & & Le Detrique Triassique & \multicolumn{4}{|c|}{ Priolithos Formation } & $\begin{array}{l}\text { Turbiditic sandstone and pelite } \\
\text { (not outcropping in the investigated area) }\end{array}$ \\
\hline
\end{tabular}

The normal non-thrusted succession of the Olonos-Pindos Formation shows Triassic clastic sediments (middle-upper Triassic Priolithos formation, after Degnan \& Robertson, 1998) overlain by siliceous limestones of the upper Triassic (Carnian) - lower Jurassic (Lias) Drimos formation (after Fleury, 1980 and Degnan \& Robertson, 1998). However, the latter was not identified during mapping in the area south of Aigion. There also is no evidence of this formation in the cuttings and cores from the AIG10 borehole. The geological and lithological situation of the area of interest can be observed in Fig. IV.27: "Geological Map of Aigion and Klokos (NW-Peloponnesus, Greece)". 
The main formations overlying the Drimos formation of the Olonos-Pindos Formation are from youngest to oldest:

- $\quad$ Post-Alpidic Units

- $\quad$ Tertiary Pindos Flysch Formation

- $\quad$ Cretaceous-Tertiary Olonos-Pindos Platy Limestone Formation

- Jurassic-Lower Cretaceous Olonos-Pindos Radiolarite Formation

\section{IV.2.2 Jurassic-lower Cretaceous Radiolarite Formation (Aalenium - Turonian)}

The youngest rocks of the Olonos-Pindos Formation, outcropping in the study area, are banded radiolarite (Fig. IV.4) and represents a deep water facies of the Pindos Ocean below the CCD (Lesteena Formation after Degnan \& Robertson, 1998). The Radiolarite Series is dated as Aalenian to Tithonian (Tab. IV.1) whereas recent studies in SW-Messinia (Neumann et al., 1996) has sited the top of the formation into late Cretaceous (Turonian). Rock dating has not taken place in the study area, so the age is an open question. Otherwise in the study area no evidence is given for a hiatus between the radiolarite and the limestone formations, hence it is assumed that the radiolarite ranges up to Lower Cretaceous.

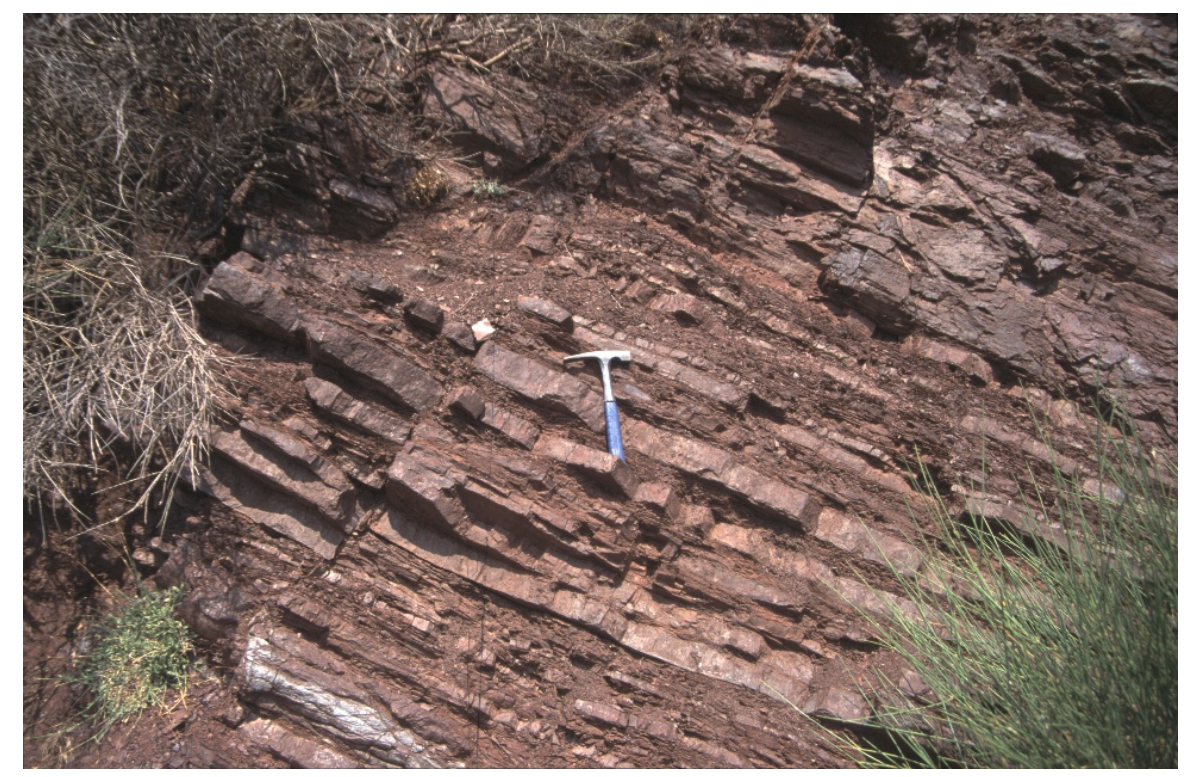

Fig. IV.4: Radiolarite of the Olonos-Pindos Formation, representing siliceous deep sea facies. They are mostly red-green to deep-red and very often unconformly interlayered with green marls or micritic limestones. 
In the entire mapped area deposits of radiolarite are very often bounded along thrust fault zones. They are red-green to deep-red, and partly magenta colored. The Radiolarite Formation is mostly unconformly interlayered with green marls, marlstone and micritic limestone and partly combined with silicious slates of chert and hornstone. Often reddish mudstone and shale appears. The real thickness of the formation is difficult to define due to the multiple imbrications. At the western slope of the Peleniko Mt. in the Klokos area a thickness of minimum $200 \mathrm{~m}$ could be estimated and is confirmed by bibliographical reference.

\section{IV.2.3 Cretaceous-Tertiary Olonos-Pindos Platy Limestone Formation (Coniacian - Paleocene)}

The Olonos-Pindos Platy Limestone Formation present in the mapped area (Lambia Formation after Degnan \& Robertson, 1998) represents mainly carbonate sediments with clastic depositions. It begins with a Calcarenit-Series of micritic limestone, calcarenite and calcisilite of pink color often intercalated with gray, greenish and reddish marlstone (Paos Formation in between the Lambia Formation).

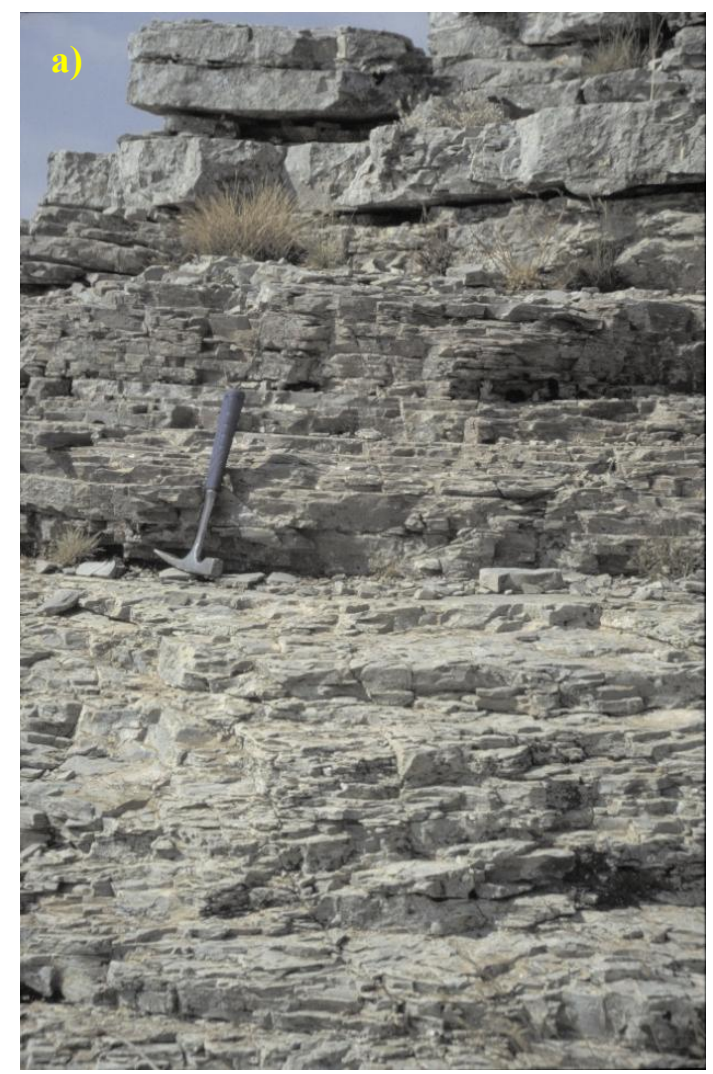

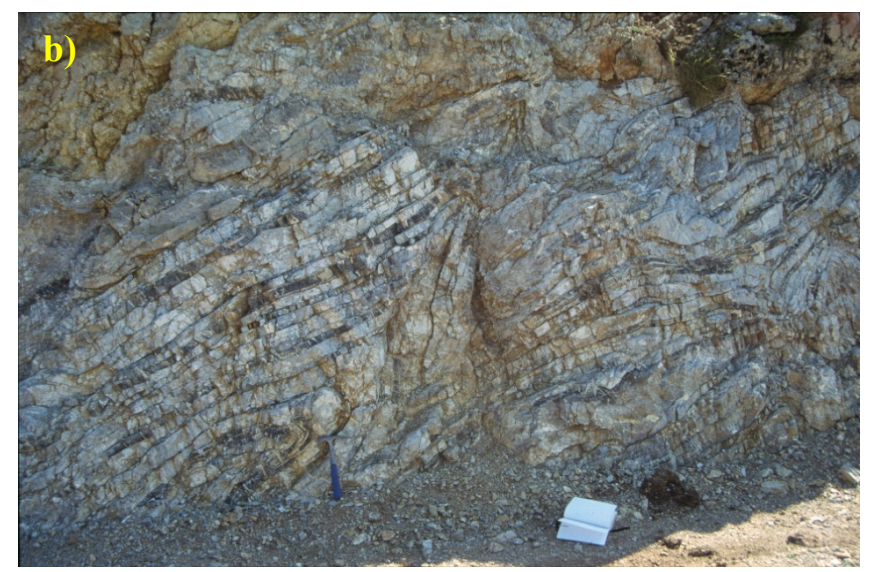

Fig. IV.5: Outcrop at the Peleniko Mt. showing the OlonosPindos Platy Limestone Formation: a) in the case of a thrusted, non-folded imbricate the series is very well bedded from $2-5 \mathrm{~cm}$, sometimes $10-15 \mathrm{~cm}$. The limestones represents mainly pelagic carbonates (micrit) of different colours and intercalations (see text). Otherwise, due to the alpidic thrusting the series are often folded in different scales mostly in NW-W verging direction. 
This series are followed by very well bedded platy limestones (Fig. IV.5a,b), the Platy-LimestoneSeries (Erymanthos Limestone Member after Degnan \& Robertson, 1998). It consist of pelagic carbonates of bright, light beige, crème-colored, reddish and pink limestones. They are mostly platy, well-stratified and well bedded micrites. Bedding reaches from 2-5 cm, sometimes 10-15 cm. They are alternating with thick bedded calcarenites, calcisilites and gray-greenish micritic limestones. In addition the series are usually interbedded with different colored marls, black chert, marlshale and silicious limestone. In some parts nodular limestones were found. On top black chert (Hornstone) and clastic sediments marks the Silicious-Clastic-Limestone-Series which lead over to a transition zone to the overlying Eocene Pindos Flysch Sandstone. The thickness of the Olonos-Pindos Platy Limestone Formation is estimated in the Klokos area to $350-400 \mathrm{~m}$.

\section{IV.2.4 Tertiary Pindos Flysch Formation (Paleocene - Upper Eocene)}

The Platy Limestone Formation is covered by hemipelagical sediments of the Upper Maastricht, representing the beginning of a transition to the Eocene flysch. Alternating green and yellow marlstones, shales and marls followed by blue-gray marlstones, calcarenites, and sandy-silty marls are characteristically for this sequence. This transition zone is estimated by Richter \& Müller, 1993 to be Paleocene and leads over to an Eocene Flysch sandstone. The thickness of the zone is identified to be $20 \mathrm{~m}$.

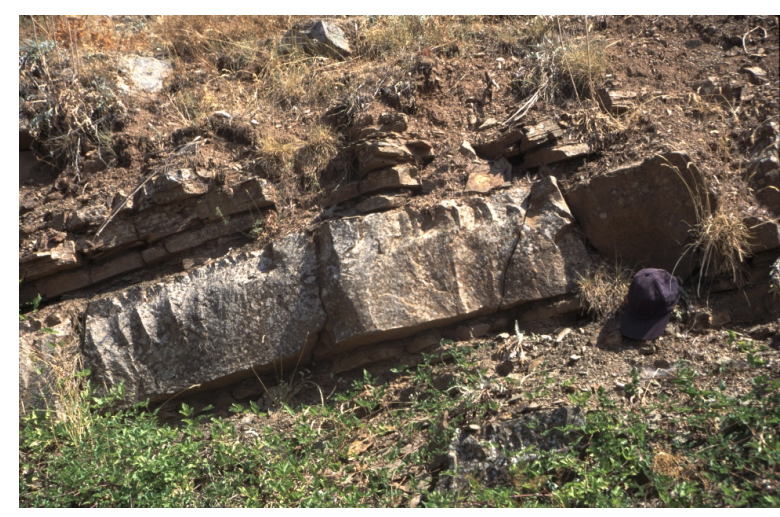

a)

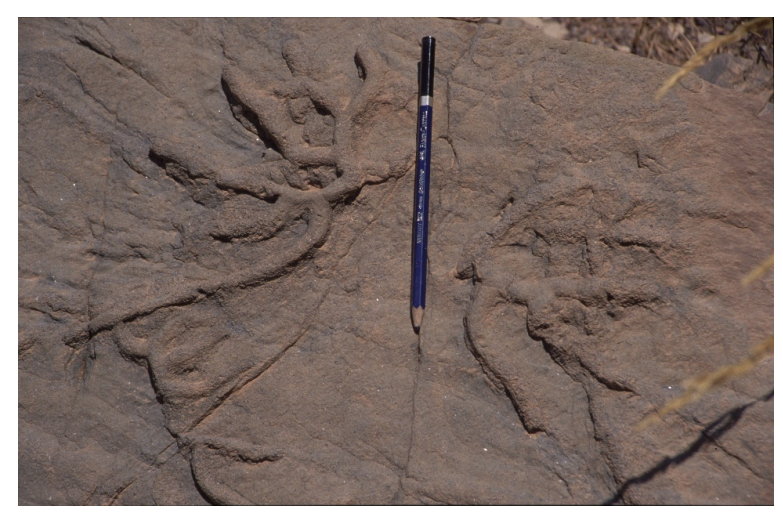

b)

Fig. IV.6: The Tertiary Pindos Flysch Formation is representing a hemipelagic environment followed by sandand siltstones: a) the mostly siliceous gray and greenish micaceous sandstone and siltstone is banked from 1-2 $\mathrm{cm}$ up to $\mathrm{dm}$. b) Ichnofossils are typical indicators for turbiditic (flysch-) sedimentation.

Above the transition zone a mostly siliceous sandstone take part, consisting of gray and greenish sandstone and siltstone (Fig. IV.6a). Ripple structures, lamination, convolute bedding and other sediment structures provide an indication of turbiditic succession (Flysch). Ichnofossils are indicators for a Flysch character as well (Fig. IV.6b). Quartz is dominating the matrix of the poorly sorted sandstone. The glimmer mineral muscovite is abundant, also chlorite (greenish color) and plagioclase. The sometimes micaceous sandstone and siltstone is in some parts intercalated by dark gray mudstone 
and pink marlstone. Particles of organic material were found like wood fragments or reed fragments. The Paleocene-Upper Eocene Flysch Sandstone (Fleury, 1980) is known as the top formation of the Olonos-Pindos nappe. In most cases, the flysch is partially or totally eroded. The upper sequence of the Tertiary Pindos Flysch Formation found in continental Greece (Degnan \& Robertson, 1998) is not outcropping in the study area.

\section{IV.2.5 The Post-Alpidic units south of Aigion (Miocene/Pliocene - Quaternary)}

The Olonos-Pindos nappe is overlain by non-thrusted but intensively block-faulted Neogene and Quaternary syntectonic deposits. These young sediments are mainly present in the northern part of the mapped area (Fig. IV.7), northern of the Eliki fault and their facies reconstruction give evidence of the syntectonic history of the area (Ghisetti \& Vezzani, 2004, Causse et al., 2004, Lemeille et al., 2004).

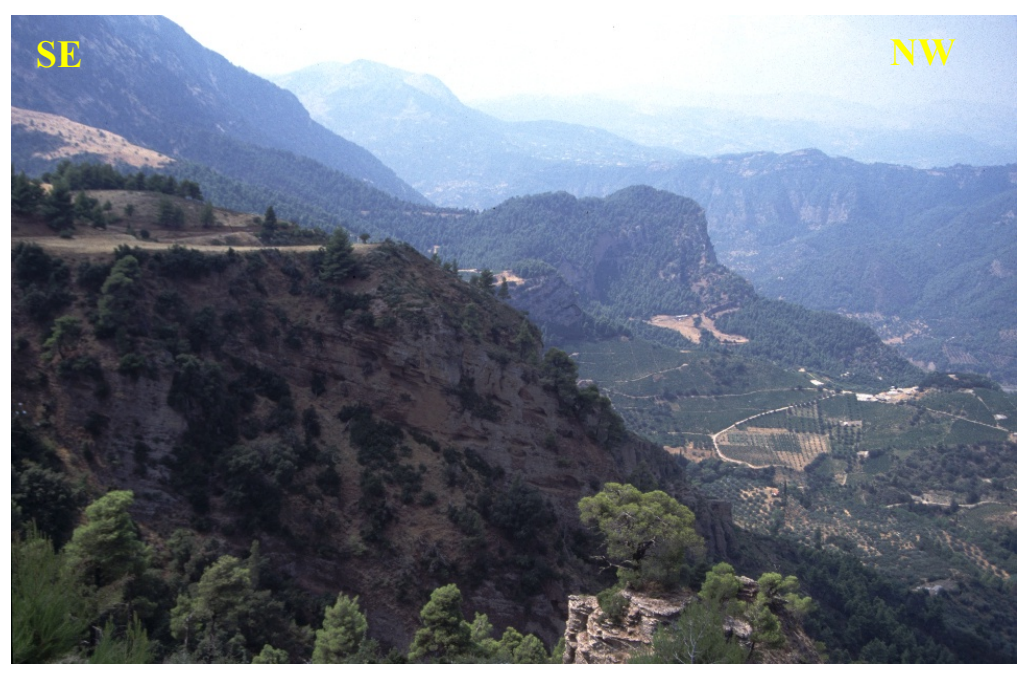

Fig. IV.7: Block-faulted Neogene and Quaternary syntectonic deposits. View direction is to the SW in direction of the Selinous river valley behind the tilted and rotated conglomerate block (middle). In front one can see a flat continental terrace. The light-coloured sequences on the right represent lacustrine-lagoonal deposits. On the left the Pyrgaki fault separates the Post-Alpidic Units from the Olonos-Pindos Formation.

\section{IV.2.5.1 Pliocene lacustrine-lagoonal deposits}

Neogene deposits are following above a transgressive contact of the Olonos-Pindos Formation (Fig. IV.8). They are lacustrine-lagoonal, fluvio-lacustrine, and brackish sands, clays, and marls from the first marine transgression of the Gulf of Corinth (late Pliocene - early Pleistocene). They consist of bright yellow, fine sandy and silty layers, interbedded with pebbly sediments and silt which are in most cases interwedged with marine intercalations. In many parts they show varvity. 


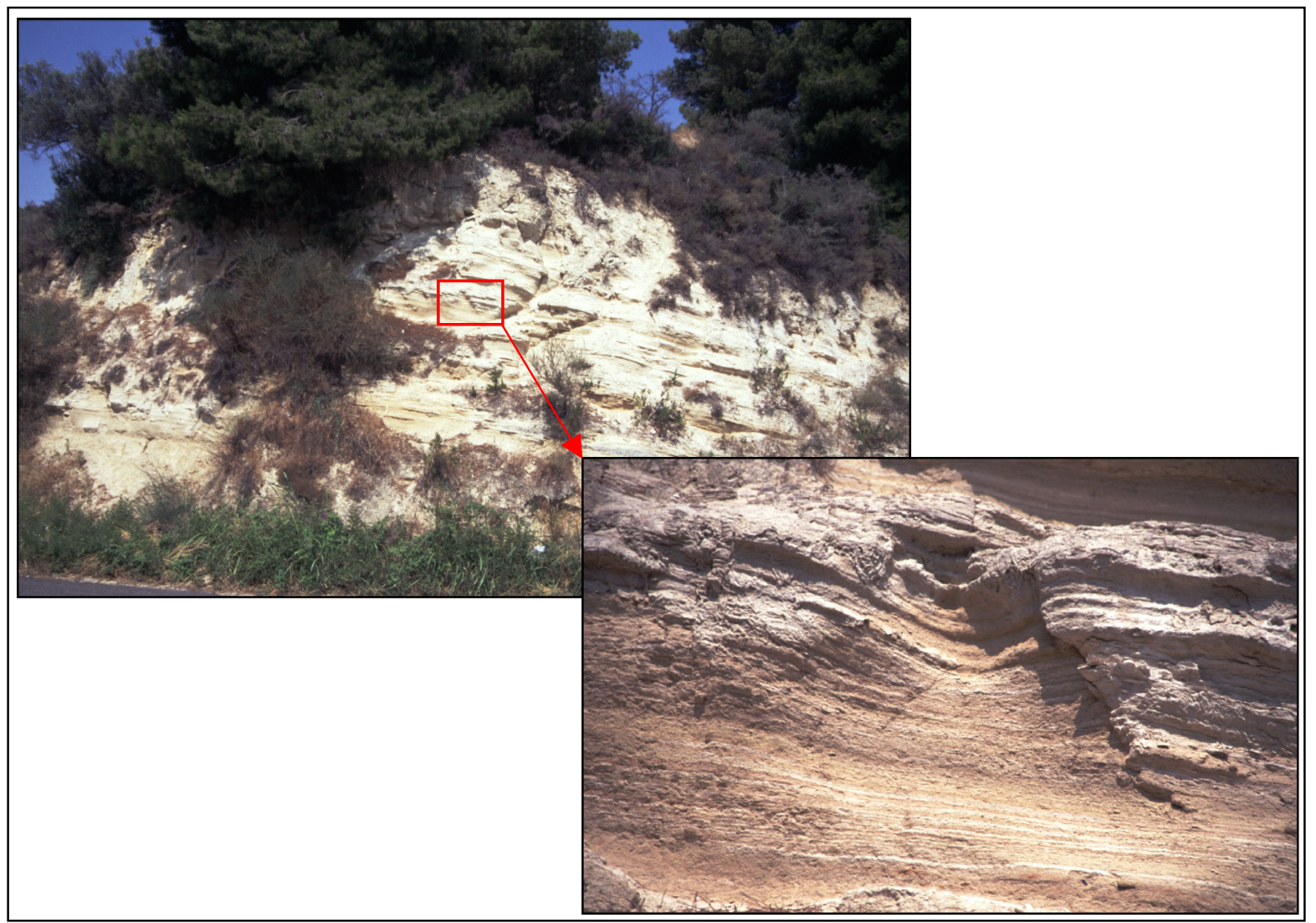

Fig. IV.8: Bright yellow, fine sandy and silty layers of the lacustrine, lagoonal, brackish and sometimes marine environment. The extraction of the outcrop shows the fine varvity of the lagoonal sands which are here onshore and uplifted to $775 \mathrm{~m}$ asl.

\section{IV.2.5.2 Pliocene - Early Pleistocene Gilbert-type delta conglomerates}

These lacustrine-lagoonal and marine sediments are overlain by consolidated, stiff conglomerates, which represent river delta environment (for example Selinous and Meganitas rivers) (Fig. IV.9a). These Pliocene-Pleistocene (?) Gilbert-type delta conglomerates show well defined topsets and foresets (e.g. Poulimenos, 1993, Malartre et al., 2004) and consist of well-rounded limestone, marl, and sandstone detritus as well as subangular radiolarites and cherts eroded from the Olonos-Pindos Formation (Fig. IV.9b). Due to the dominance of limestones and radiolarite the matrix is often calcareous and/or siliceous. Depending on the matrix material the rock resistance is therefore different and hence the hydraulic and thermal properties. In the case of prevailing calcareous matrix the conglomerates are showing karstic features and focused water paths. Otherwise siliceous conglomerates are more dense occurring in lower permeability but higher thermal conductivity. It is important to sample different conglomerates to evaluate good average formation parameters. 

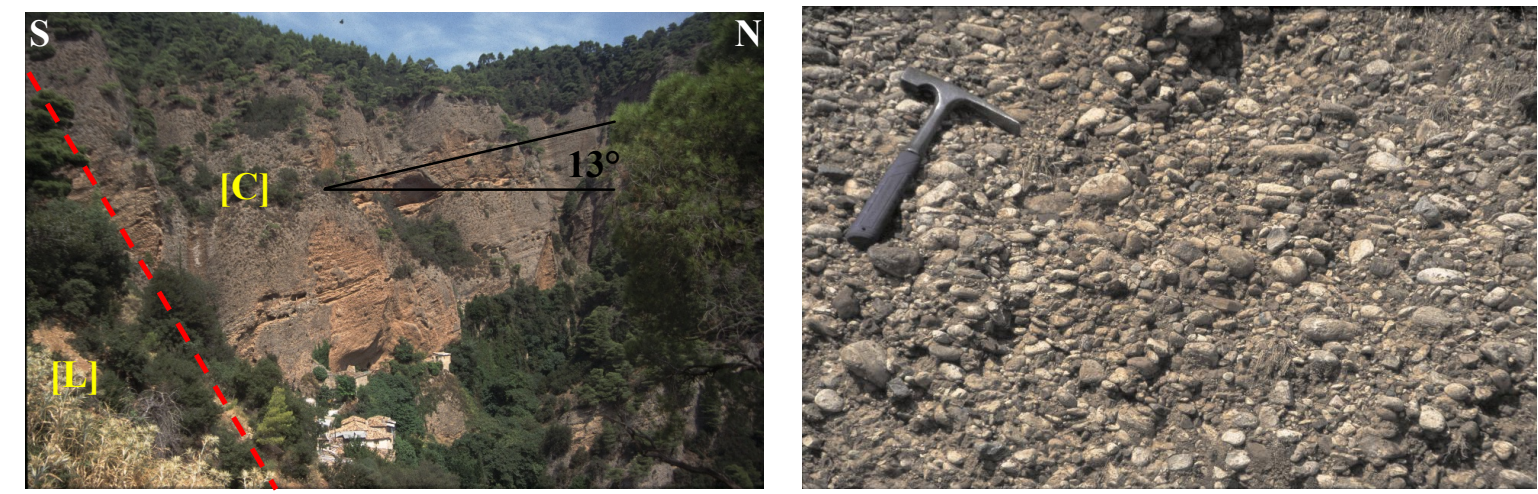

a)

b)

Fig. IV.9: Gilbert-type delta conglomerates: a) at the Monastery Pepelenitsas the conglomerates [C] are up to $500 \mathrm{~m}$ thick and are uplifted to $>700 \mathrm{~m}$ asl. Here they are back tilted $\left(13^{\circ}\right.$ south) representing the hangingwall of the Pyrgaki fault (dashed line) with limestones in the footwall [L]. b) the delta conglomerates show well defined topsets and foresets and consist of well-rounded limestone, marl, and sandstone detritus as well as subangular radiolarites and cherts.

\section{IV.2.5.3 Quaternary deposits}

The Pleistocene/Holocene Formations consist of fluviatile, limnic, or terrestrial sediments with some marine intercalations. The vertical displacement of sometimes more than $1000 \mathrm{~m}$ produces strong relief and therefore big mass movements. Talus deposits, landslides, debris fall and rock fall material is the consequence.

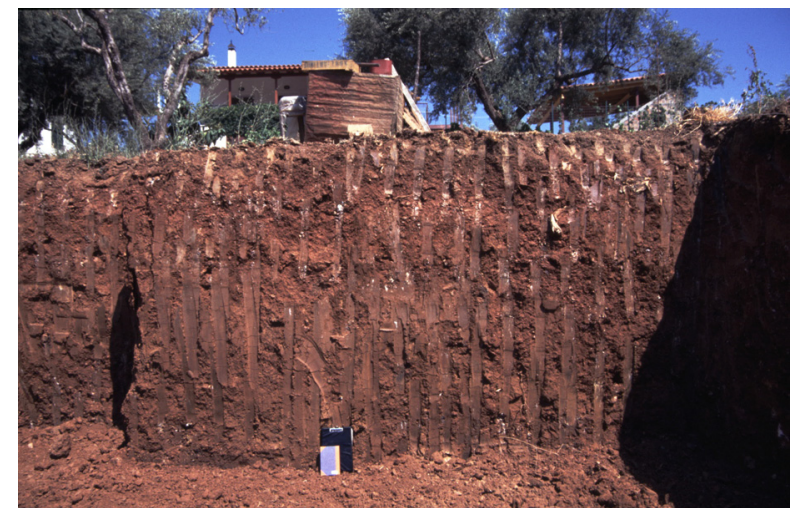

a)

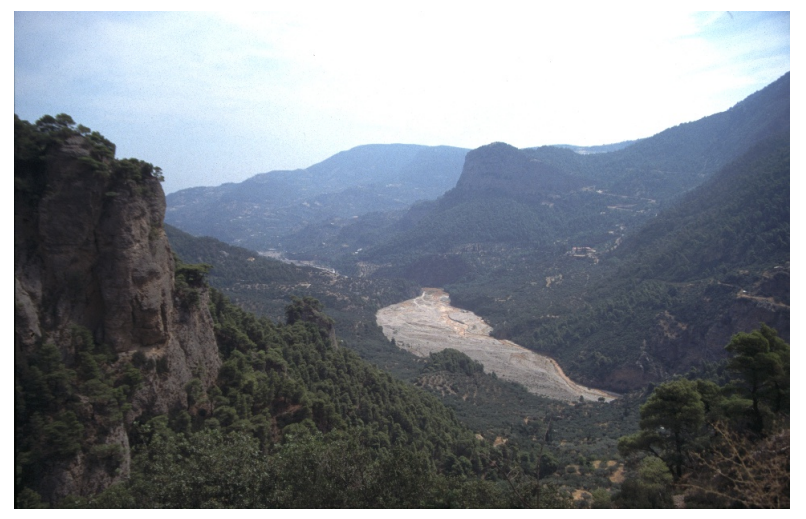

b)

Fig. IV.10: Examples of Quaternary deposits: a) red soil of clayey to silty and mostly carbonate free loam in intensively agricultural used areas. b) Fluviatile sediments at the Selinous river flanked by Gilbert-type delta conglomerates on the hanginwall of the Pyrgaki fault. The strong relief and regional uplift generates rock fall and landslides producing talus fan deposits. 


\section{IV.3 Geological map of Aigion and Klokos}

Geological maps of the Aigion area are not available and not yet published but constitutes the base of the investigations for geological-tectonical and hydrogeological understanding. Only the knowledge about Geology and Tectonics give evidence about the geological-tectonical structures necessary for evaluating a well developed conceptual model. Stratigraphy and bedding as well as cross sections for the model domain and sampling points for typical rocks are important for the project task (Fig. I.1). In the following a approximately $80 \mathrm{~km}^{2}$ geologic-tectonic map including several cross sections for understanding the typical geological-tectonical structure will be discussed. Further on a $22 \mathrm{~km} \mathrm{~N}-\mathrm{S}$ cross section for the compilation of the hydrogeological conceptual model domain and defining the model architecture is developed. The geological-tectonical structure was also a key for interpreting the succession encountered in the AIG10 borehole (Rettenmaier et al., 2004). A geological outline about the Aigion area and AIG 10 drill site was given in chapter IV.1. The descriptions and remarks done in this chapter are comprehensible in the Geological Map of Aigion and Klokos (Fig. IV.27) and the 22 $\mathrm{km} \mathrm{N}-\mathrm{S}$ cross section in Fig. IV.28 at the end of this chapter (page 47).

Overall the Olonos-Pindos Formation is wholly allochthonous, therefore the geological structure of the area is very complex. Duplex structures as well as thrusts and thrusted folds lead to multiple imbrications and alternating of several stratigraphic sequences, resulting in changes in lithology in a short distance. The strain and deformation of the Olonos-Pindos Formation into a series of multiple imbricates is expressed mainly in the southern part of the geological-tectonical map (Fig. IV.27). Here the typical structure of the Olonos-Pindos Formation, which comprises in normal bedding at lower sequences the Jurassic-lower Cretaceous Radiolarit Series (Fig. IV.4), followed by the CretaceousTertiary Platy Limestone Series (Fig. IV.5) and Tertiary Flysch Sandstone (Fig. IV.6) on the top can be studied (Rettenmaier, 2002).

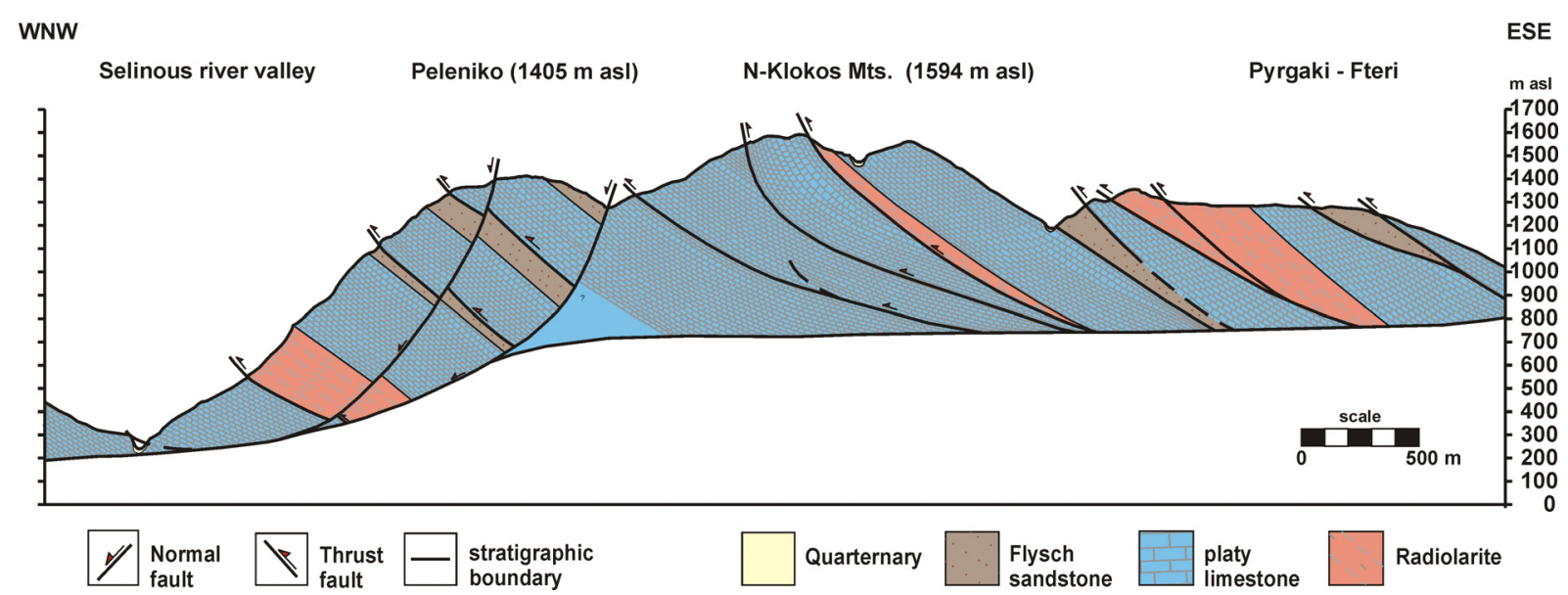

Fig. IV.11: Cross section of the Alpine overthrusted Olonos-Pindos nappe, mapped and investigated in the Klokos Mountains, approximately $18 \mathrm{~km}$ south of the AIG10 borehole (Rettenmaier et al., 2004). Note that the listric normal faults of the cross section at the Peleniko Mountain are dipping to the west and are related to gravitational mountain collapsing (Selinous river valley) and not to the extensional tectonical features of the Gulf (location see Fig. IV.27). 


\section{Thrust faults}

The thrust faults, dipping mostly to the SE and connected with NW-verging folds, are belonging to the Miocene thrust tectonic. The youngest formation outcropping in the southern area are banded radiolarite. In the entire mapped area deposits of radiolarite are very often bounded along these alpidic generated thrust fault zones (Fig. IV.12). Due to the multiple imbricates the real thickness of the formations are often difficult to define. At best the thickness can be defined at the western slope of the Peleniko Mt. and in the Klokos area where the Olonos-Pindos Formation is thrusted on glide planes and subhorizontal successions are prevailing. Otherwise in other parts the successions occur under distinctive folding.

Intensive cataclasite or mélange zones are not connected to the thrust fault planes. Mostly they are characterized through shear folds, tilted fold hinges, back limb thrusting and/or ramp thrusting which are separating the hanging- and foot wall in clearly defined traces. If the fault plane is following along marls or marly rocks the structures show dragging and well developed duplexes. Thrusting along flat planes and ramps is generating roof thrusts with fanning and branching of the fault planes. Mainly in the SW of the mapped area above Agios Mavriki several thrust planes are leading to a very complex interplay of these structures.

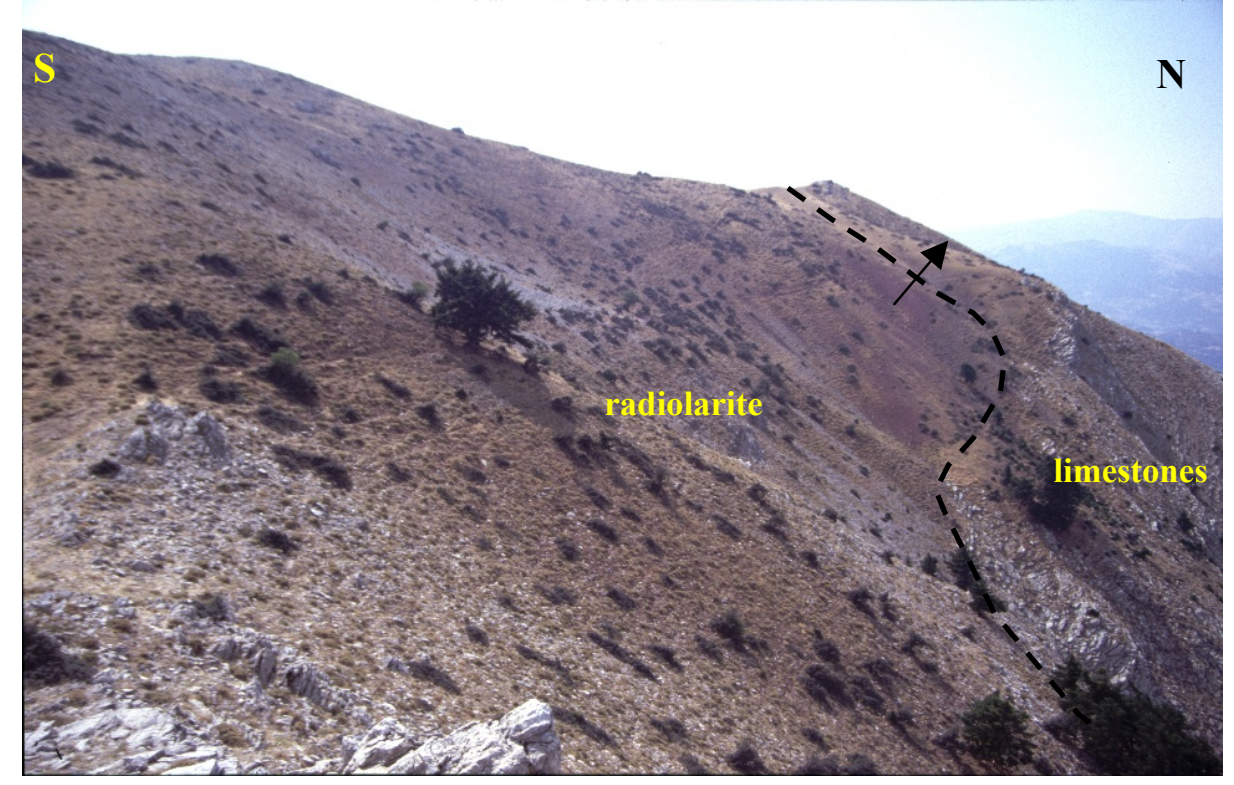

Fig. IV.12: Thrusting of approximately $80 \mathrm{~m}$ thick older radiolarite (red) onto the younger Olonos-Pindos limestones in NW direction (black arrow). The thrust trace can be recognized through a morphological step (dashed line). The picture is taken at the westerly flanc of the Mt. Klokos in westerly direction. 
In between the platy limestones thrust planes are often connected to marly intercalations or sandy marls which are rheological more incompetent. Besides this they are connected to lithological boundaries with different shear resistance and competency contrast. Very often the more competent radiolarites are thrusted onto the less competent platy limestones or limestone is overthrusted onto incompetent Flysch sandstone. Sometimes Flysch sandstone is in direct contact to radiolarite (Fig. IV.27).

Thrust direction is in most cases in NW direction (NW-vergency resp. SE-dipping). In the Fteri area $\mathrm{N}$-verging thrusting exists as well which is very likely the result of deformation when the leading edge of the tip line of a thrust fault is emerging on the surface. The stereographic projection in Fig. IV.13 a and $\mathrm{b}$ is showing the analysis of strike and dip values of about 60 thrust fault planes. The striking maximum is clearly defined by a NE-SW direction and the dipping show mainly NW vergence (SE dipping). $\mathrm{W}$ and $\mathrm{N}$ vergence can be recognized on secondary maxima. Mostly the fault planes are dipping shallow with dip angles of $20-40^{\circ}$. Only in the Peleniko region steep listric thrust faults in the limestones are generated which are nearly leading to back thrusting (Fig. IV.11).

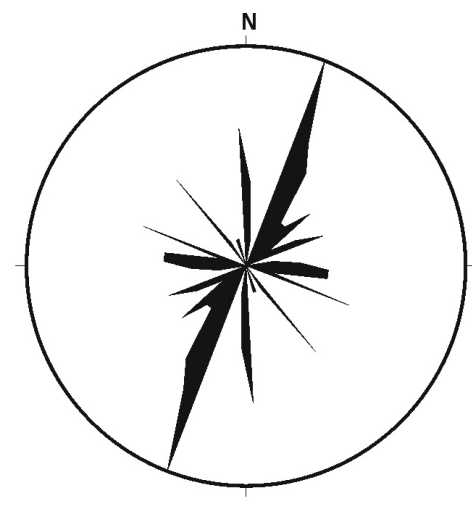

a) Strike: stereographic projection $n=60$

scale: periphery $13 \%$

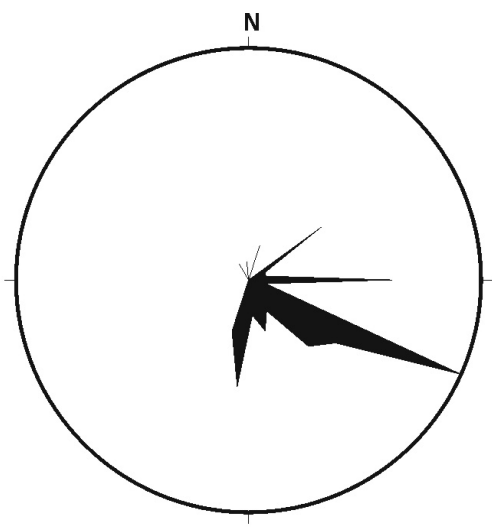

b) Dip stereographic projection $n=60$ scale: periphery $21 \%$

Fig. IV.13: Stereographic projection of a) strike- and b) dip directions on 60 measured thrust faults in the mapping domain (Rettenmaier, 2002).

\section{Joint system}

The alpidic thrust tectonic has generated a relatively well developed joint system. In the mapped area joint sets were analyzed with regard to the formation permeability of the sequences. In contrast to tectonical stress generated joints and fissures release joints on the surface have to be considered. At depth loading is leading to less permeability than expected from surface. The joint density, joint spacing and direction of the joint propagation and striking of joint traces are depending on the maximum principle stress $\left(\sigma_{1}\right)$ and the minimum compressive stress $\left(\sigma_{3}\right)$ in the formation. Depending on the rock competency and petrophysical rock properties dilatation and mechanical failure is leading 
to fractures on joint planes which offer angles of $>45^{\circ}$ in respect to $\sigma_{1}$ (Eisbacher, 1996). In the mapped area the joint sets are well developed and the joint system is built in three directions (Fig. IV.14a,b). The thrust tectonic has generated slap shaped to orthogonal fissures. The striking maximum of the Olonos-Pindos Formation show mostly N to NNE direction which means dilatation in E-W and a connection to the alpidic thrust direction. The second maximum in Fig. IV.14a of ENE direction is very likely connected to neogene extensional structures and is parallel to the Gulf of Corinth extension.

The results of the joint investigations showing fracturing in three more or less orthogonal directions is later on confirmed by the pumping test results (chapter V.2). This test has shown fractured approach for fractured aquifer conditions assuming slab-shaped or spherical shaped blocks. Considering the lithostatic load it is assumed that the well developed joint system of the limestones is more of slabshaped characteristics. On surface the joint density of representative outcrops show 10 to 15 joints per $1-\mathrm{m}$ in all three directions. The joint spacing is mostly 3 to $10 \mathrm{~mm}$, sometimes up to $20 \mathrm{~mm}$. The joints are rarely healed and veins are mostly connected to marls or marly limestones.

The development of the joint system due to strong tectonical stress and the low joint healing indicate that the joints in the platy limestones provide as preferential water ways at depth. The platy limestones show better distinct fracturing and jointing than the more competent radiolarite or the Flysch sandstones.

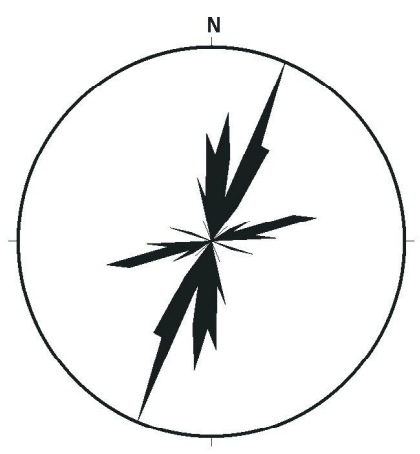

Strike:

stereographic projection $n=70$

a)

scale: periphery $12 \%$

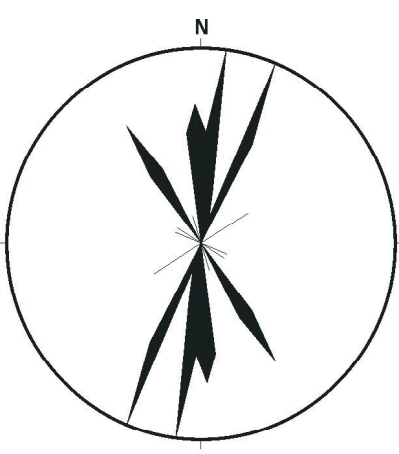

Strike:

stereographic projection $n=50$

b)

scale: periphery $14 \%$

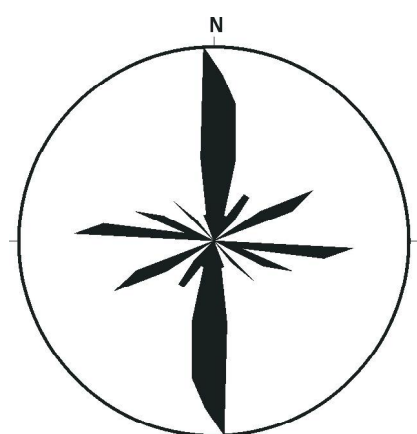

Strike: stereographic projection $n=60$

c) scale: periphery $11 \%$

Fig. IV.14: Stereographic projection of joint values demonstrating strike arrangement of selected outcrops in between the Olonos-Pindos Platy Limestone Formation: a) outcrop at the westflank of the Klokos mountain in $1500 \mathrm{~m}$ asl; b) outcropping platy limestones on the street Fteri - Ponti valley (SE map periphery); c) outcrop at the Selinous valley pumping test site EQ1 (Rettenmaier, 2002). 


\section{Folds}

Due to the above mentioned thrusting of the Olonos-Pindos Formation the sequences are folded in different scales and wave lengths. While the Olonos-Pindos limestones at the Klokos Mts. sometimes subhorizontal layered small scaled folds can occur, primarily at high competency contrast and when accompanied with marls or weak zones. Radiolarite as well show very often intensive folding. Fig. IV.15 a-d are showing some examples of the prevailing fold structures. The enveloping fold surfaces of the Olonos-Pindos nappe in the mapped area show mostly W-verging tendency in NW to SW direction and are bounded very often at thrust fault planes. Fig. IV.15 a) displays the analysis of folded radiolarite showing W-vergency. The fold axis is measured to 176/49 E which is the similar value measured for the thrust fold plane in direct contact. Fig. IV.15 b) is another example of a fold bounded to the thrust direction in the area of Agio Mavriki.

The platy limestones are accompanied with radiolarites and marls and are thrusted along a SE dipping fault plane below this sequence. The fold axis of the asymmetric anticline show NW vergency (019/72 SE). The interlimb angle is $68^{\circ}$. Fig. IV.15 c) investigated at the western flanc of the Mt. Klokos represents a nearly upright-symmetric fold of homogeneous banked red radiolarite. The direction of the fold axis is $162^{\circ}$ to the SW and is plunging very steep with $74^{\circ}$ to the NE (SW verging). The interlimb angle is approx. $86^{\circ}$. The fold in the platy limestones of the hangingwall of the Ponti fault Fig. IV.15 d) represent a asymmetric anticline and show SW verging tendency (146/56 NE). The anticline is characterized through a very steep forelimb $\left(82^{\circ}\right)$ and a more shallow backlimb $\left(30^{\circ}\right)$. The interlimb angle is $53^{\circ}$ and show contraction at the fold core.

In general folding in the mapped area is connected to the prevailing alpidic tectonical structure. They are corresponding to their competency contrast and can be classified as flexural-flow folds (after Eisbacher, 1996). In most cases they are asymmetric or are recumbent, upright, or diving folds in westerly fold directions. The tectonical structure with complex folding have to be considered when the AIG10 borehole is analyzed. Additionally, the structure is important when real thrust faults has to be distinguished between folds and sheared folds in the small scale of a litho log. The alpidic thrusts and tectonical repetitions were additionally block-faulted by the neotectonics of the Corinth Rift, especially within the first $15-20 \mathrm{~km}$ to the south of Aigion. They are faulted or displaced at synthetic or antithetic normal faults. Additionally gravitational mass movements are often bounded to preexistent thrust fault planes. 

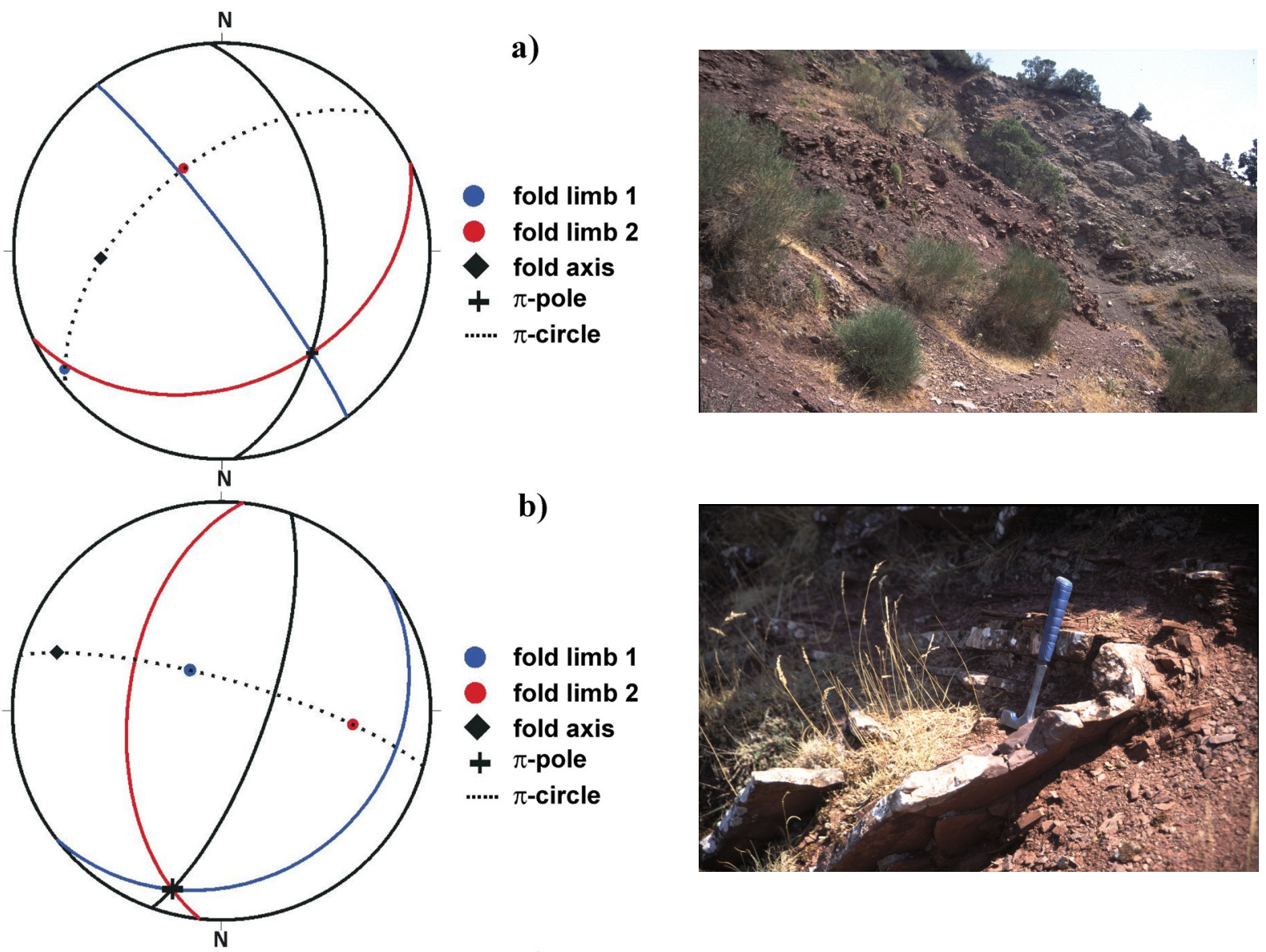

b)

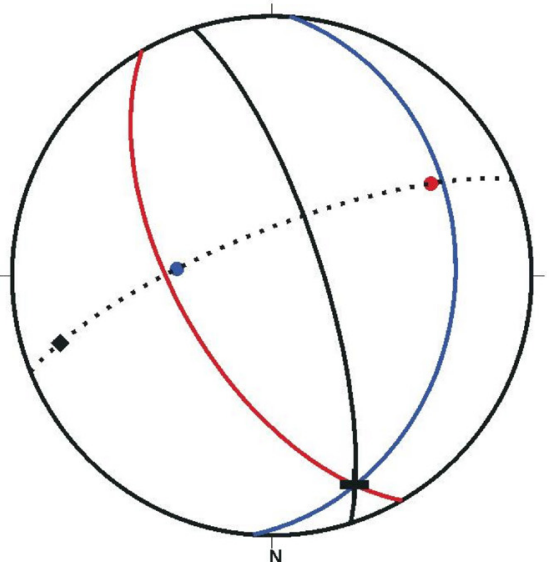

c)

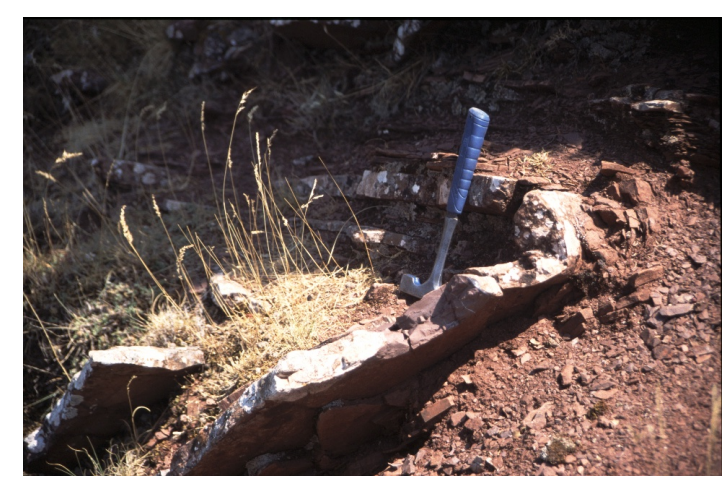

fold $\operatorname{limb} 1$
fold limb 2
fold axis

$+\pi$-pole

...... $\pi$-circle
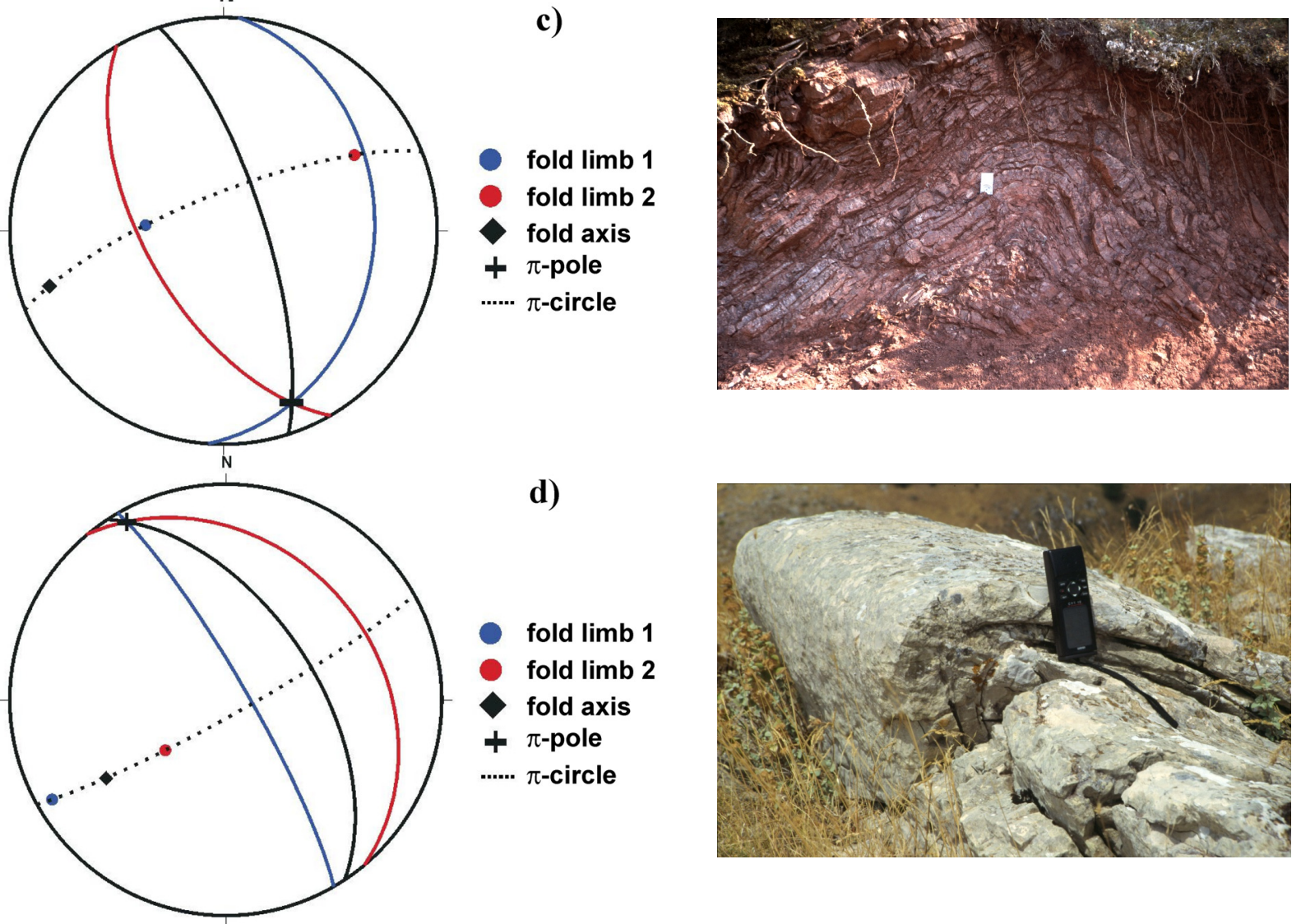

d)

- fold limb 1

fold limb 2

- fold axis

$+\pi$-pole

..... $\pi$-circle

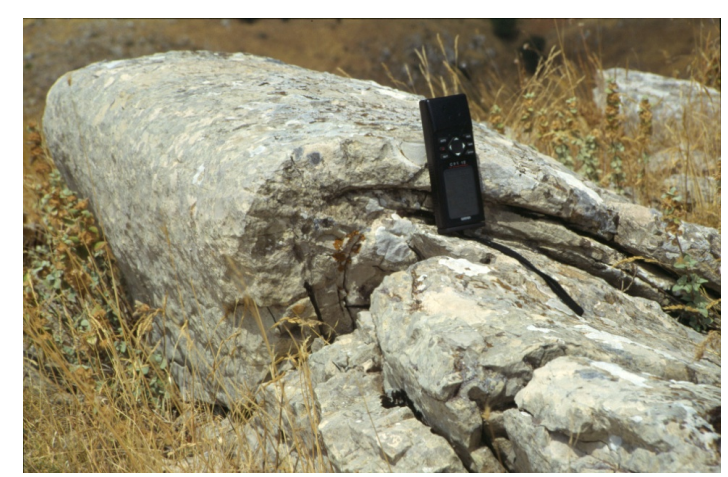

Fig. IV.15: Stereographical analysis of prevailing fold structures in the mapping area (details in the text). (Rettenmaier, 2002) 


\section{Normal faults: Ponti fault}

At the southern boundary of the mapping area a distinctive fault scarp runs in E-W direction (Fig. IV.16). The location of this normal fault, which is nowhere described in the literature, is $4 \mathrm{~km}$ south of the Pyrgaki fault and $1.5 \mathrm{~km}$ south of the Klokos mountain peak in a area called Ponti valley

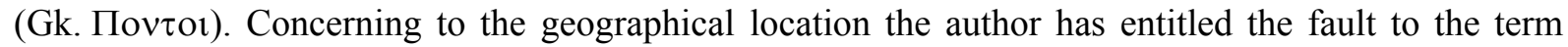
"Ponti normal fault" (Rettenmaier, 2002). In the mapping area the fault escarpment has a length of 3.7 $\mathrm{km}$ but continues to the $\mathrm{E}$ and to the $\mathrm{W}$. The strike direction is clearly associated to the direction of the E-W extension of the Gulf of Corinth.

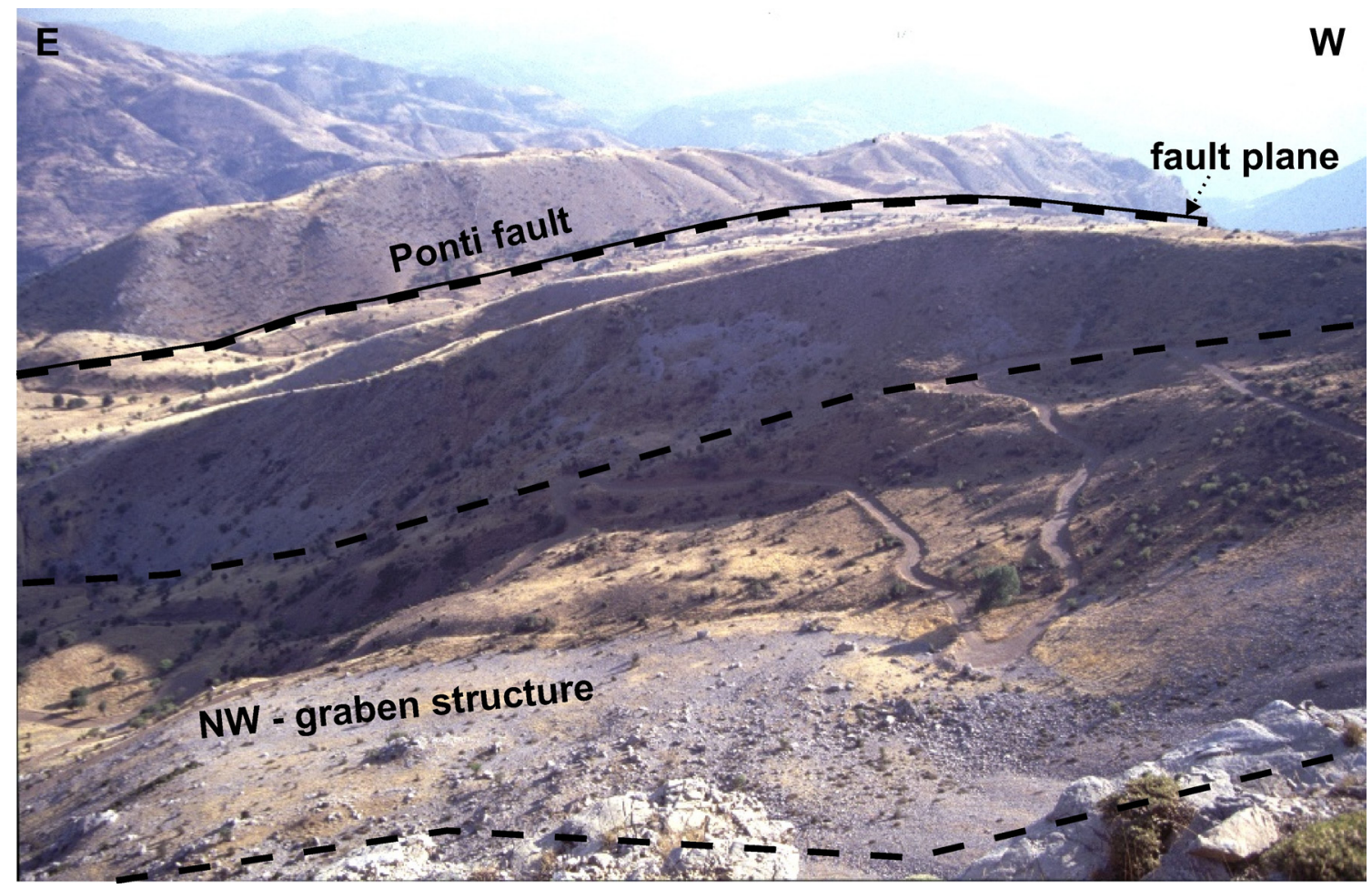

Fig. IV.16: Fault escarpment of the Ponti normal fault $1.5 \mathrm{~km}$ south of Mt. Klokos and $4 \mathrm{~km}$ south of the Pyrgaki fault.

The fault escarpment starts at a $100 \mathrm{~m}$ deep trench in the SE along the road Fteri - Petzaki at the junction to Agios Mavriki. The trench is filled with fluviatile detritus and debris fall material. The escarpment can be followed along a clearly expressed relief to the west and is accompanied with a NW-oriented graben structure of Flysch sandstones (Fig. IV.16). This central part of the Ponti normal fault separates limestones of the hangingwall from green-brown Flysch sandstones at the foot wall. The sandstones are leading to a flat erosional surface in this area (Rettenmaier, 2002).

The SW part of the Ponti fault is characterized through a $300 \mathrm{~m}$ outcropping fault plane showing slickensides and tectonical striae on the surface (Fig. IV.17 a-d). The average strike direction of the fault plane is $130^{\circ} \mathrm{WNW}-\mathrm{ESE}$ and is conform with the Gulf extension. Dipping direction is from $45^{\circ}$ 
to $60^{\circ}$ (average $53^{\circ}$ ) to the NNE. Oblique striae on the polished fault plane are dipping in a close interval of $356^{\circ}-001^{\circ}$ to the north which means a $15^{\circ}$ sinistral displacement (Fig. IV.18). The overall vertical displacement is at minimum $400 \mathrm{~m}$ measured from the Flysch sandstone at the hangingwall cutoff.

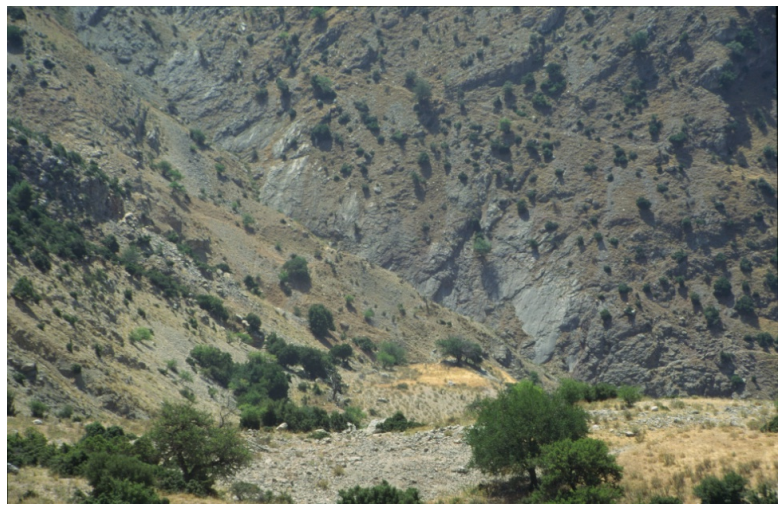

a)

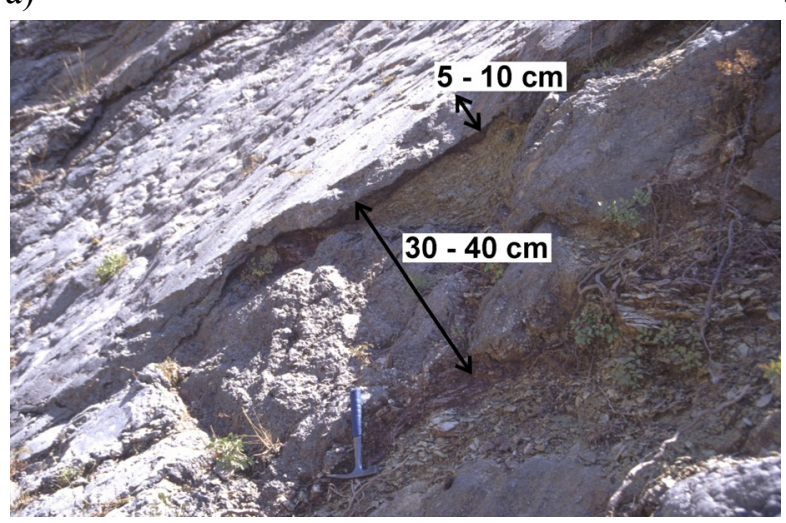

c)

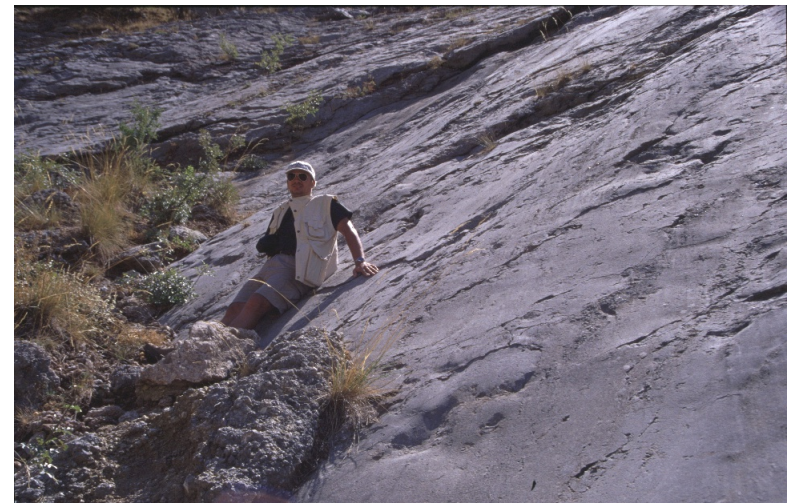

b)

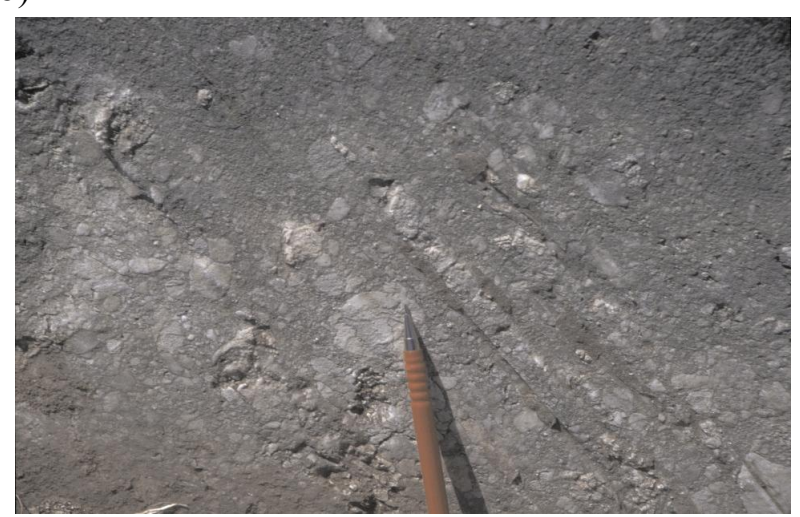

d)

Fig. IV.17: Fault analysis on the Ponti normal fault. The $300 \mathrm{~m}$ long and $50 \mathrm{~m}$ high surface fault plane offering well possibilities for field studies a). Dipping is $45^{\circ}$ to $60^{\circ}$ in WNW-ESE direction b) and the cataclastic zone reaches at maximum $50-80 \mathrm{~cm} \mathrm{c}$ ). Tectonical striae on the fault plane and embedded cataclasite fragments in a fine gray carbonatic matrix (Rettenmaier, 2002).

Faulting at the Ponti fault in between a limestone - limestone contact has not performed a well developed cataclastic zone. The assembly of the Ponti fault plane can be studied on a $50 \mathrm{~m}$ high outcrop at the SW corner of the mapped area (Fig. IV.17c). A vertically cutout show a cross section of the fault. The surface fault plane consists of a $5-10 \mathrm{~cm}$ well cemented limestone breccia followed by a $30-40 \mathrm{~cm}$ thick compacted red and green marl zone (weak zone). The surface is characterized by a very well cemented dilatational breccia with sharp edged limestone fragments. Slickensides show oblique tendencies similar to the other outcropping planes measured. 


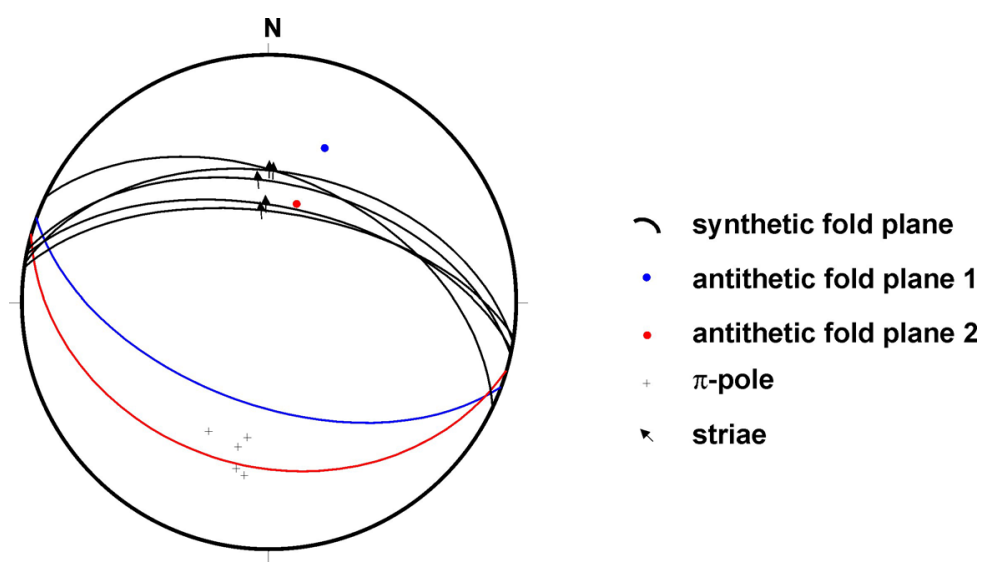

Fig. IV.18: Stereographic projection of the Ponti normal fault. The strike direction averages at $130^{\circ} \mathrm{WNW}$-ESE with a dipping of $53^{\circ}$ NNE. The tectonical striae on the fault plane (arrows) show about $15^{\circ}$ sinistral displacement.

Due to the movement along the fault plane brecciated cataclasites were embedded in a fine gray carbonatic matrix (Fig. IV.17d). Probably marls act as a weakening zone and supports the normal faulting. The outer margins of the cataclasite fragments are not in contact with each other. The reason can be that during the displacement with sliding and fracturing of the limestones fluids are able to circulate between them at the fault line (Eisbacher, 1996). After a displacement stagnancy the fluid mineralization is crystalling out and the cataclasite fragments were embedded in between a dense carbonatic matrix. The $50-80 \mathrm{~cm}$ thick gliding plane is then considered to be hydraulically semipermeable or even impermeable and provide a hydraulic barrier when fluid wants to cross the plane.

It is anticipated here that the semi-permeable hydraulical fault behavior is later on confirmed by the hydraulic tests in the foot wall of the Eliki normal fault (close to the hangingwall) and by the hydraulic test made at the Aigion fault in the AIG10 borehole (chapter V.2). Core analysis of the Aigion fault zone has shown nearly identical composition of the faulted sequence.

\section{Normal faults: Pyrgaki fault}

In the geological map of Aigion and Klokos (Fig. IV.27) the Pyrgaki fault can be very well identified through a E-W-trending fault line and strong relief which separates the Olonos-Pindos Formation from Neogene deposits farther north. Due to the contact to the Gilbert-type delta conglomerates the hangingwall of the Pyrgaki fault is branching and segmented more than other faults running in between the limestones. At the limestone footwall cutoff well defined normal fault planes are present showing kinematic indicators like tectonic striae and slickensides. Overall the fault surface can be followed for at least 30-40 km along the southern shore of the Corinthian Gulf. In the study area $7 \mathrm{~km}$ of the E-W striking fault surface is mapped. The vertical displacement is determined from $200 \mathrm{~m}$ and $500 \mathrm{~m}$ to $600 \mathrm{~m}$ westerly of the Pyrgaki village. The maximum displacement of $700 \mathrm{~m}$ is identified at the Monastery Taxiarchon in the Selinous river valley. 
a)

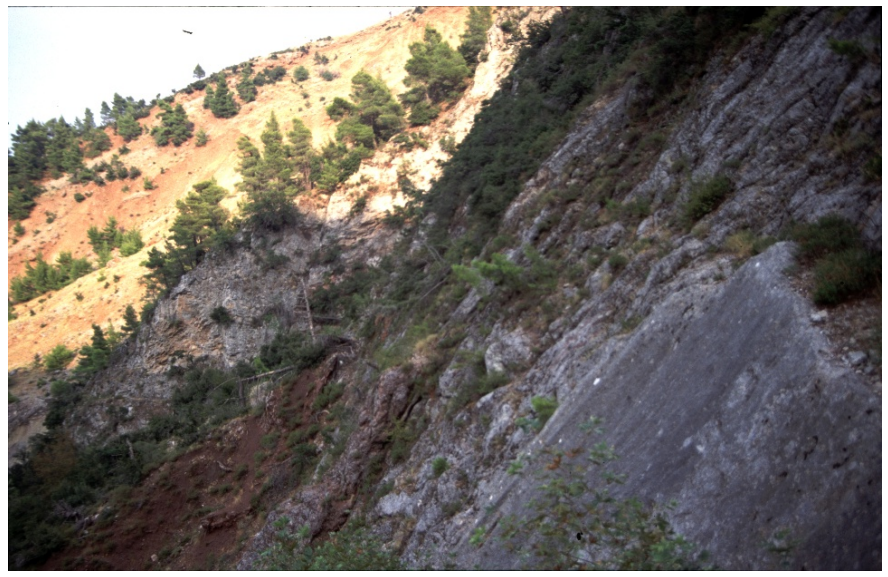

b)

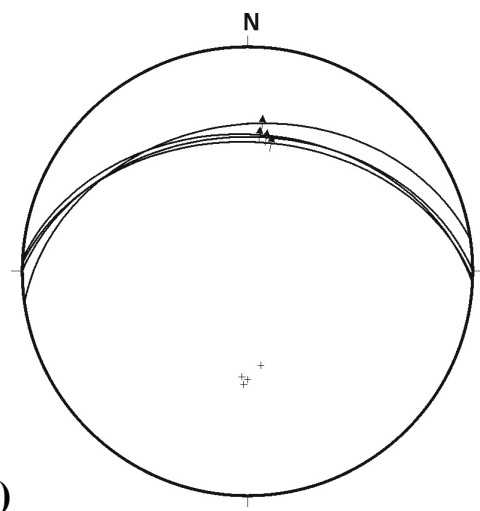

Fig. IV.19: a) Pyrgaki fault $1 \mathrm{~km}$ to the west of the Pyrgaki village with b) stereographic projection.

a)

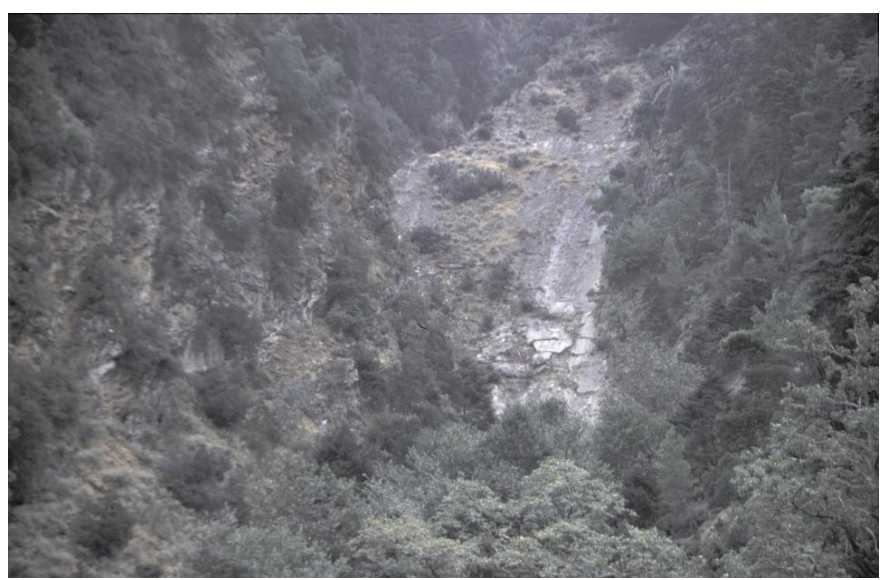

b)

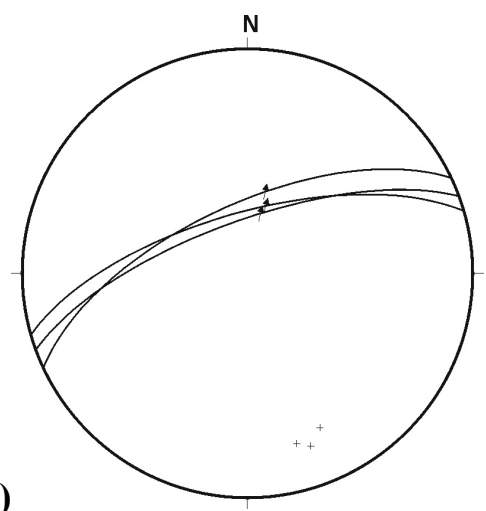

Fig. IV.20: a) Pyrgaki fault plane in the center of the mapped area with b) stereographic projection.

In general the Pyrgaki fault is dipping with a steep angle of $65^{\circ}-70^{\circ}$ to the north and striking direction is $90^{\circ}-110^{\circ}$ in E-W direction. Fig. IV.19 and Fig. IV.20 are representing two typical examples where fault characteristics were studied for taking into account by the preperation of the hydrogeological conceptual model (chapter VII.2). Fig. IV.19a shows the situation approximately $1 \mathrm{~km}$ to the west of the Pyrgaki village. The fault separates Olonos-Pindos limestones (hangingwall) from Delta conglomerates (footwall, background of the picture). The fault plane is striking nearly exact E-W (average $92^{\circ}$, Fig. IV.19b). Tectonical striae are showing divergencies of $0^{\circ}-8^{\circ}$ pointing to a smart dextral sense of displacement. Fig. IV.20a displays a several hundred of meters outcropping fault plane $3 \mathrm{~km}$ to the west of the Pyrgaki village. The $20^{\circ}$ dextral normal fault plane is dipping steep $\left(65^{\circ}-\right.$ $72^{\circ}$ ) to the north and is sriking with averaged values of $68^{\circ}$ E-W Fig. IV.20b.

Important for the conceptual model is again the fact that the fault surface show similar characteristics like the analyzed fault plane of the Ponti fault accompanied by marly weak zones and a fault thickness of some meters which will very likely have an effect on the hydraulic conductivity of the fault planes at depth. In contrast to the conglomerates, the Mesozoic Olonos-Pindos formation at the Pyrgaki fault show different behavior when affected by normal faulting. 


\section{Normal faults: Melissia and Kerynia faults}

The area between the Pyrgaki fault and the Eliki fault $6 \mathrm{~km}$ farther north is characterized by several synthetic and antithetic normal faults which are subparallel to the E-W striking main faults of the Corinth rift (Fig. IV.27). To the west of the Selinous valley they are cutting mainly delta conglomerates. North striking transform faults are accompanied which are merging to the Pyrgaki fault in the south and the Melissia fault to the north. In the western part of the geological map the Melissia fault trace runs in-between the Gilbert-type delta conglomerates in E-W direction. The fault escarpment produces a distinct morphological step and a vertical displacement of $120 \mathrm{~m}$. The strike direction on a selective outcrop is showing $358^{\circ} \mathrm{E}-\mathrm{W}$ and a dip of $66^{\circ}$ to the north (Bauer, 2004).

The eastern part of the Melissia fault scarp where the N-S cross section for the conceptual model goes through is displaced of about $1.5 \mathrm{~km}$ to the north along a transform fault. At this area the Selinous river is following the transfer fault trace. Due to the displacement the Melissia fault describes a curvature and is ending to the west in outcropping Olonos-Pindos rocks where kinematic indicators can be studied on a fault surface (Fig. IV.21a). The synthetic normal fault plane is dipping relatively steep to the NW (320/62) and striae show dextral sharing (linear 028/40) (Fig. IV.21b). The southern domain of the fault can be described as a horst structure accompanied by two antithetic normal faults dipping to the south. The horst structure and antithetric fault system between Lakka and Achlades is part of the overall N-S cross section displayed in Fig. IV.28. The system is striking in NE-SW direction and the limestones are in contact with lacustrine-lagoonal deposits and Delta conglomerates (partly covered by Quaternary deposits).
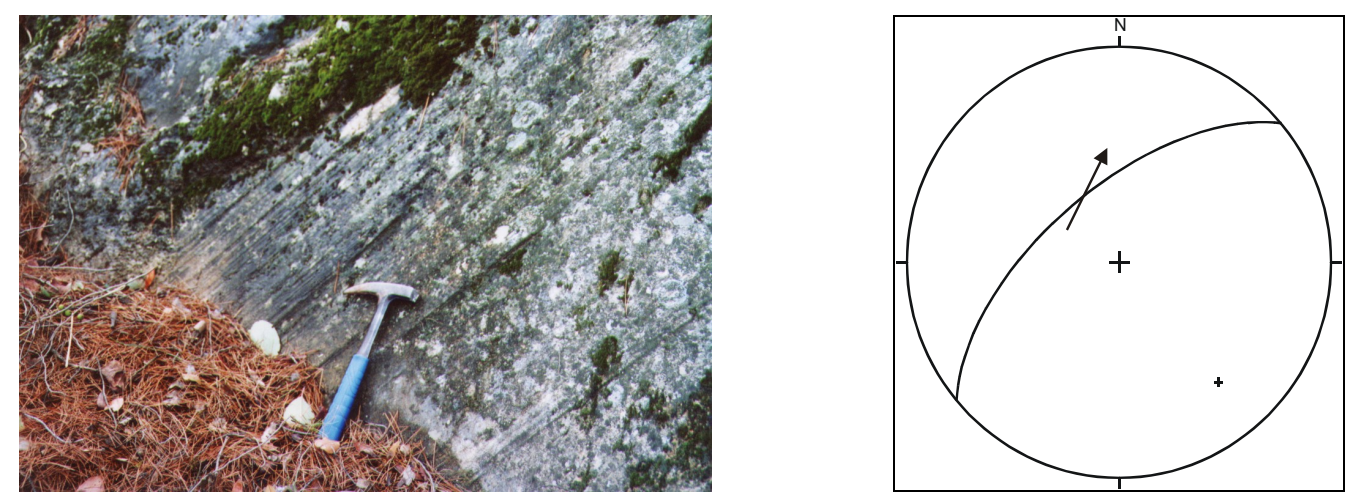

Fig. IV.21: Kinematic indicators on the Melissia fault plane a) with dip- and strike directions b) (Bauer 2004).

The area between the Melissia fault and the Kerynia fault to the west of the Selinous river valley is characterized through a flat plateau with en-echelon disposed step faults. The cross section $\mathrm{E}-\mathrm{F}$ is displaying the west plateau with the Kerynia fault to the north and the Melissia fault to the south (Fig. IV.22). The averaging dipping direction of the synthetic normal faults in between is $55^{\circ}$ (Bauer, 2004). In contrast to the normal faults along limestone-limestone contacts the conglomerate fault zones are branched and show more variable segmentations affecting the hydraulic properties of the sequence. The hydraulic behavior of faulted conglomerates will be discussed later on a outcrop along the Eliki fault. 
The Kerynia synthetic normal fault is regarded as a $15 \mathrm{~km}$ long southern fault segment of the main fault Eliki (Fig. IV.3). Approximately $6 \mathrm{~km}$ of the fault is running through the northern part of the mapping area between the Selinous river to the east and the Meganitas river to the west. The trace is running predominantly in-between Delta conglomerates and red soil and is often covered by fluviatile detritus, rock fall and landslide material (Bauer, 2004, Unkel, 2003). Thus the fault escarpment is not expressed very good at surface and dipping angles could not be defined. However, the minimum vertical displacement of the Kerynia fault could be found to be at least $150 \mathrm{~m}$.

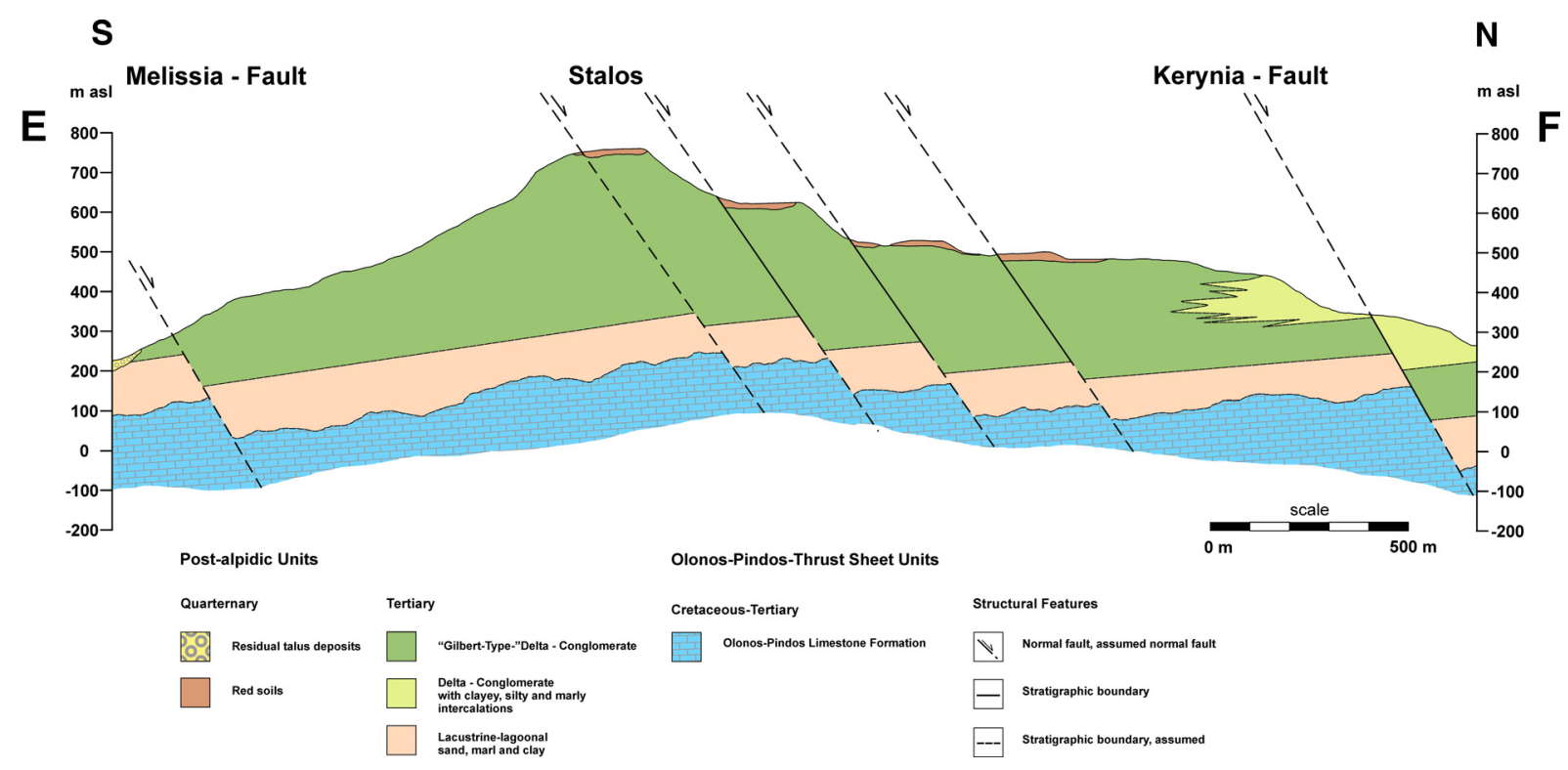

Fig. IV.22: Geological cross section E-F from the Melissia fault to the Kerynia fault further north (Bauer, 2004) (location see geological map).

\section{Normal faults: Eliki fault}

Assuming that the initiaton of the rift extension causes fault migration from the south to the north the Eliki fault have to be younger than the Ponti and Pyrgaki faults. According to the recent seismic events it is very likely that the Eliki fault is still active (e.g. Pitilakis et al., 2004). The Eliki fault represents a north dipping normal fault, is at least $40 \mathrm{~km}$ long, and is continuing offshore to the west (segment A Fig. IV.2). In the mapping domain approximately $7 \mathrm{~km}$ of the fault trace is present and is running mainly in between delta conglomerates (Fig. IV.27). The fault plane of the footwall in the east is showing the underlying limestones and is sometimes in direct contact with the limnic-lagoonal to marine sediments Fig. IV.23a. The northward migration of the faults is leading to a forward migration of the conglomerate deposits showing that fault activity was/is synchronos with the depositions of the Gilbert-type delta conglomerates (Rettenmaier 2002, Unkel, 2003). 

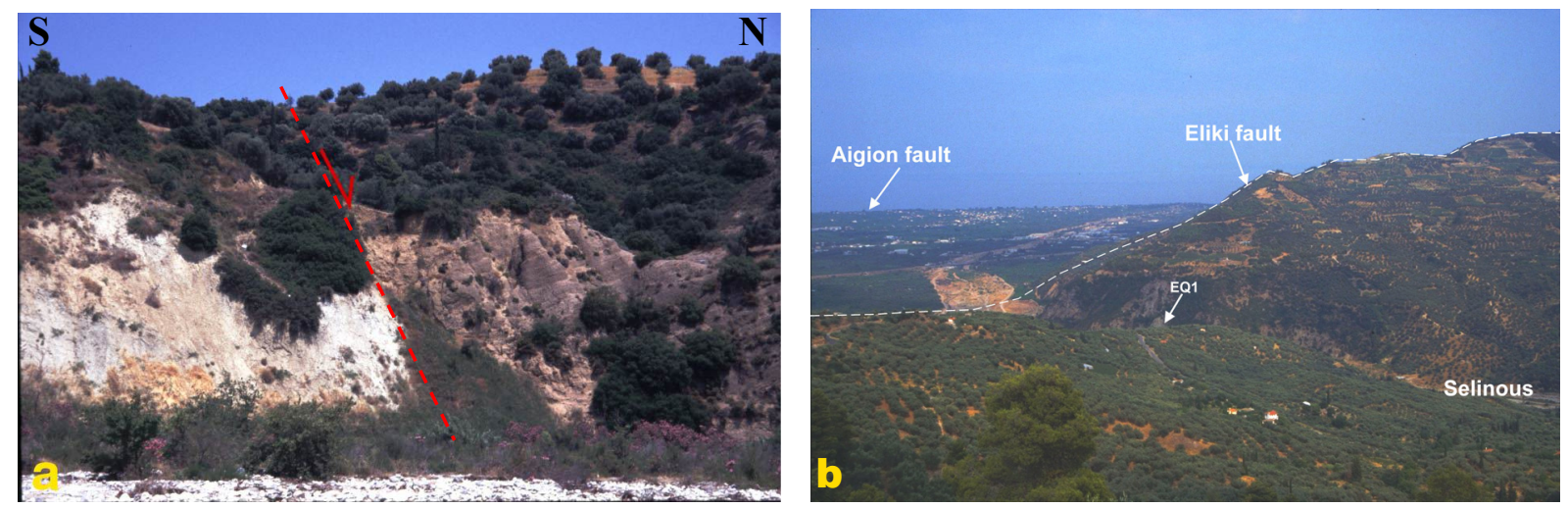

Fig. IV.23: The Eliki fault outcropping to the south of Aigion. a) The Eliki fault (red arrow) in direct contact with limnic-lagoonal deposits (footwall) and delta conglomerates (hangingwall) (Unkel, 2003). b) The Eliki fault with a minimum displacement of $850 \mathrm{~m}$ estimated at the pumping test site EQ1 in the Selinous river valley is expressed in a clear morphological step (dashed line, view in northern direction) (Rettenmaier, 2002).

The Eliki fault is expressed in a clear morphological step parallel to the coastline with elevations up to $500 \mathrm{~m}$ (Fig. IV.23b). Headward erosion occur where the trace is running in conglomerateconglomerate contact. A displacement of minimum $850 \mathrm{~m}$ could be estimated at the pumping test site EQ1 in the Selinous valley (Rettenmaier, 2002). Up to $950 \mathrm{~m}$ are specified by Doutsos \& Poulimenous, 1992.

The mapped part of the fault describes a synthetic normal fault with a average strike direction of $63^{\circ}$ to the NE-SW (Unkel, 2003). The dipping angle is averages about $60^{\circ}$ and is sometimes steepened to $70^{\circ}$. The outcropping Eliki fault plane in Fig. IV.24 outcropping approx. $100 \mathrm{~m}$ north of the pumping test site is showing the prevailing strike and dip directions (333/60). The slickensides on the fault plane give evidence of a oblique normal faulting with a dextral shear component (Linear 006/65).

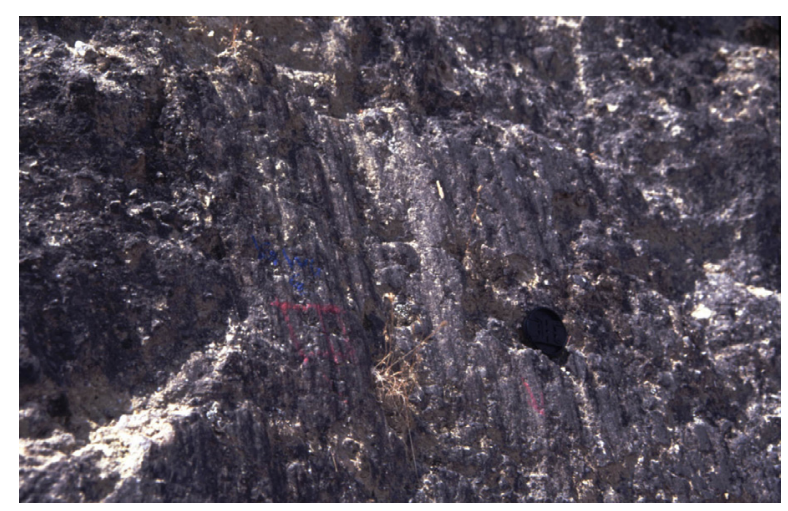

Fig. IV.24: Tectonical striae on the Eliki fault plane. The Eliki fault is representing a East-West striking synthetic normal fault with a relatively steep dipping angle of $60^{\circ}(333 / 60)$. Tectonical striae on the fault plane show dextral displacement (L 006/65). 
The Eliki fault show a similar fault structure as the Ponti and Pyrgaki fault when arranged in between limestones. The fault core is characterized of a only some meters thick zone and is accompanied by marls or marly layers. The semi-permeable fault behavior of the Eliki fault assumed through the macroscopic investigations was later confirmed by the hydraulic test at the well EQ1.

Fig. IV.25 demonstrates the assembly of the Eliki fault when arranged in between conglomerates. In contrast to the limestone-limestone contact the fault zone show several alternating fault traces and segments arranged at a wide-ranged zone. Here the faulted zone has reached 50-80 m but can also rise up to several hundreds of meters. On the difference in hydraulic fault behavior controlled by and depending on the constitution of the fault contact have to pay attention when including it to the hydrogeological conceptual model. Additionally different fault contact parameters have to be considered by the preparation of the final numerical model.

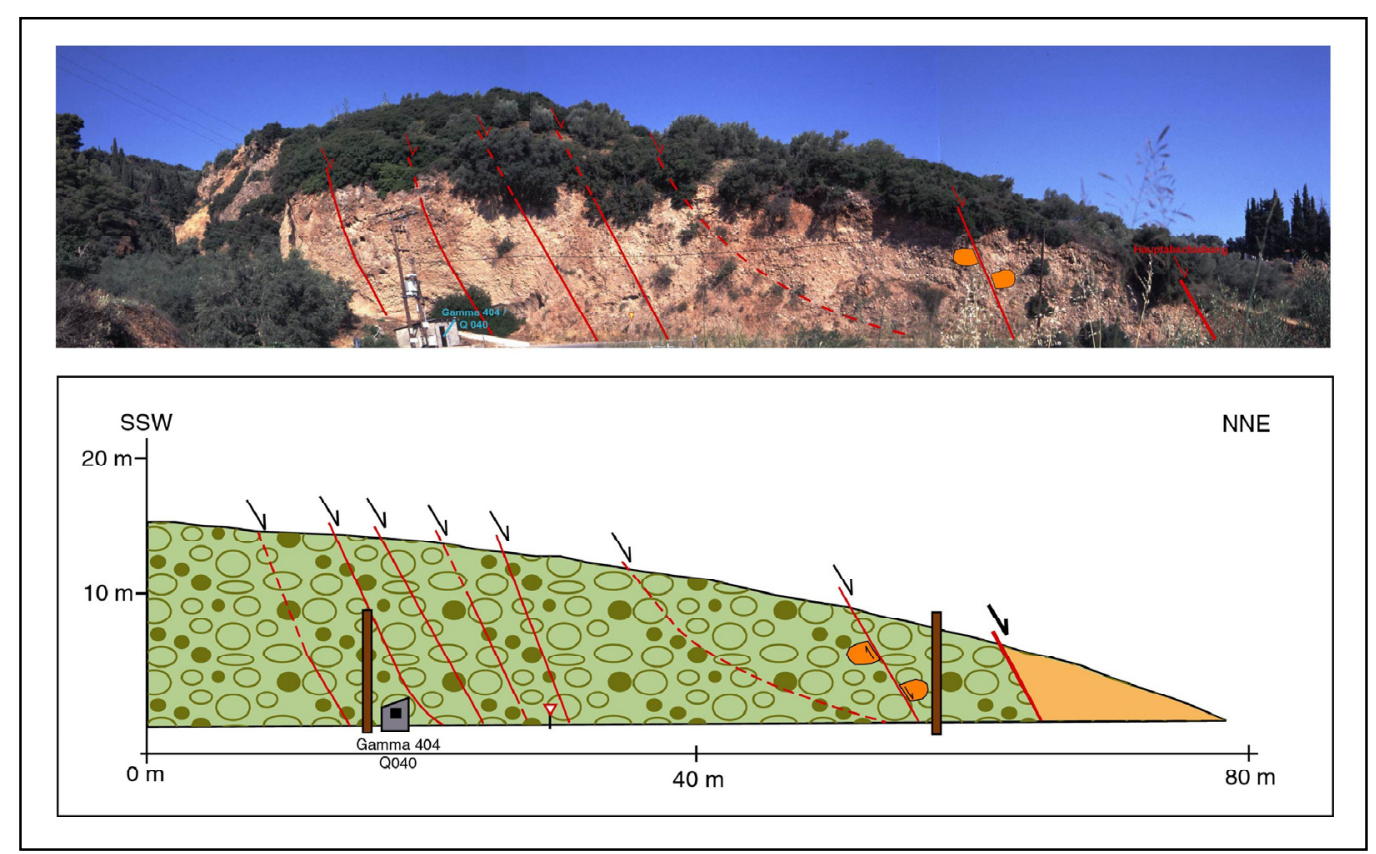

Fig. IV.25: Eliki fault characteristics when arranged in between delta conglomerates (Unkel, 2003). The constitution of the fault contact is affecting the hydraulic fault behavior. In contrast to the fault zones occurred at limestone-limestone contacts the fault zone show several alternating fault segments at a wide-ranged zone.

\section{Normal faults: Aigion fault}

The flat area with low relief between the Eliki fault and Aigion fault farther north is covered by delta conglomerates, quaternary red soils, and fluviatile deposits of the rivers Selinous (east) and Meganitas (west) (Fig. IV.27). $4 \mathrm{~km}$ of the $12 \mathrm{~km}$ long Aigion fault is passing through the northern part of the mapped area and is containing the central Aigion segment and the eastern part of the Agios Konstantinos segment (Unkel, 2003). Both faults are lying $3.8 \mathrm{~km}$ apart and are controlling the sedimentation processes in the area. The bending to the east of both rivers give evidence that the two faults are connected through a accommodation zone leading to a east tilting basin floor of the fault block segment (Koukouvelas, 1996). 


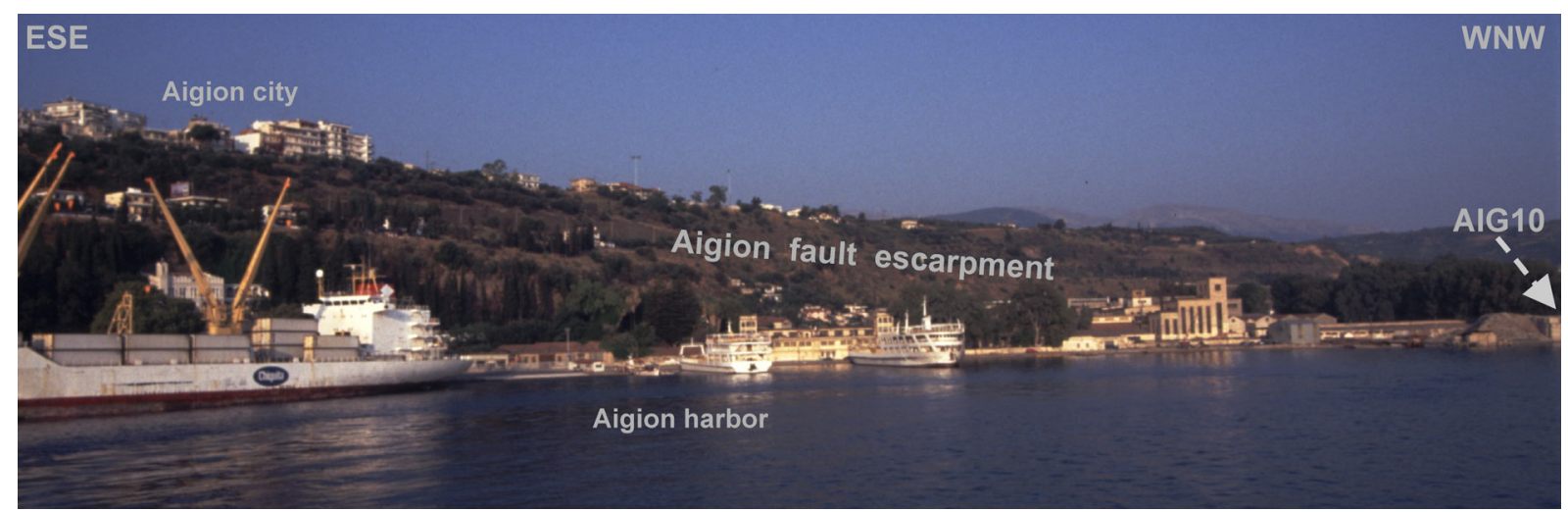

Fig. IV.26: The E-W striking synthetic Aigion normal fault is forming a clear fault escarpment of about $60-80 \mathrm{~m}$ and separates the Aigion harbor from the city (Unkel, 2003). The spud in point is located $470 \mathrm{~m}$ apart in the NW of the harbor.

Outcropping fault planes of the Aigion fault on the surface are not present in the mapping area. However, the E-W striking fault is forming a clear fault escarpment of about $60-80 \mathrm{~m}$ and separates the waterfront from the city of Aigion (Fig. IV.26). At a cross bearing in the Meganitas valley the Aigion fault dip could be estimated to $010 / 35$ which means a relatively flat dipping direction to the north. Koukouvelas et al., 1996 has been estimated the slope angle of the fault escarpment prevailing in the central part of the mapped fault to $37^{\circ}$ which is conform to our investigations. The AIG10 borehole spud in point is located in the Meganitas river deposits and has crossed the Aigion fault plane at $760 \mathrm{~m}$ depth (chapter V.1). The result of the AIG10 litho-log together with the surface investigations were invaluable for the generation of the N-S cross section and the hydrogeological conceptual model. The fault cores have shown identical fault compositions like the Ponti-, Pyrgaki-, and Eliki fault mentioned before and similar hydraulic behavior can be assumed for the Aigion fault. Further detailed hydraulic fault characteristics of the Aigion fault zone are derived from hydraulic tests and will be discussed in chapter V.2. 
Fig. IV.27 Geological-tectonical map of Aigion and Klokos. 


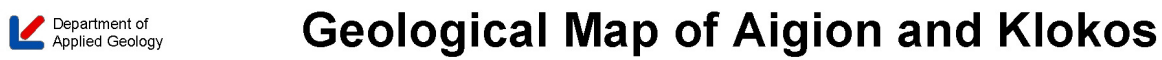 (Gulf of Corinth, NW-Peloponnesus, Greece)}

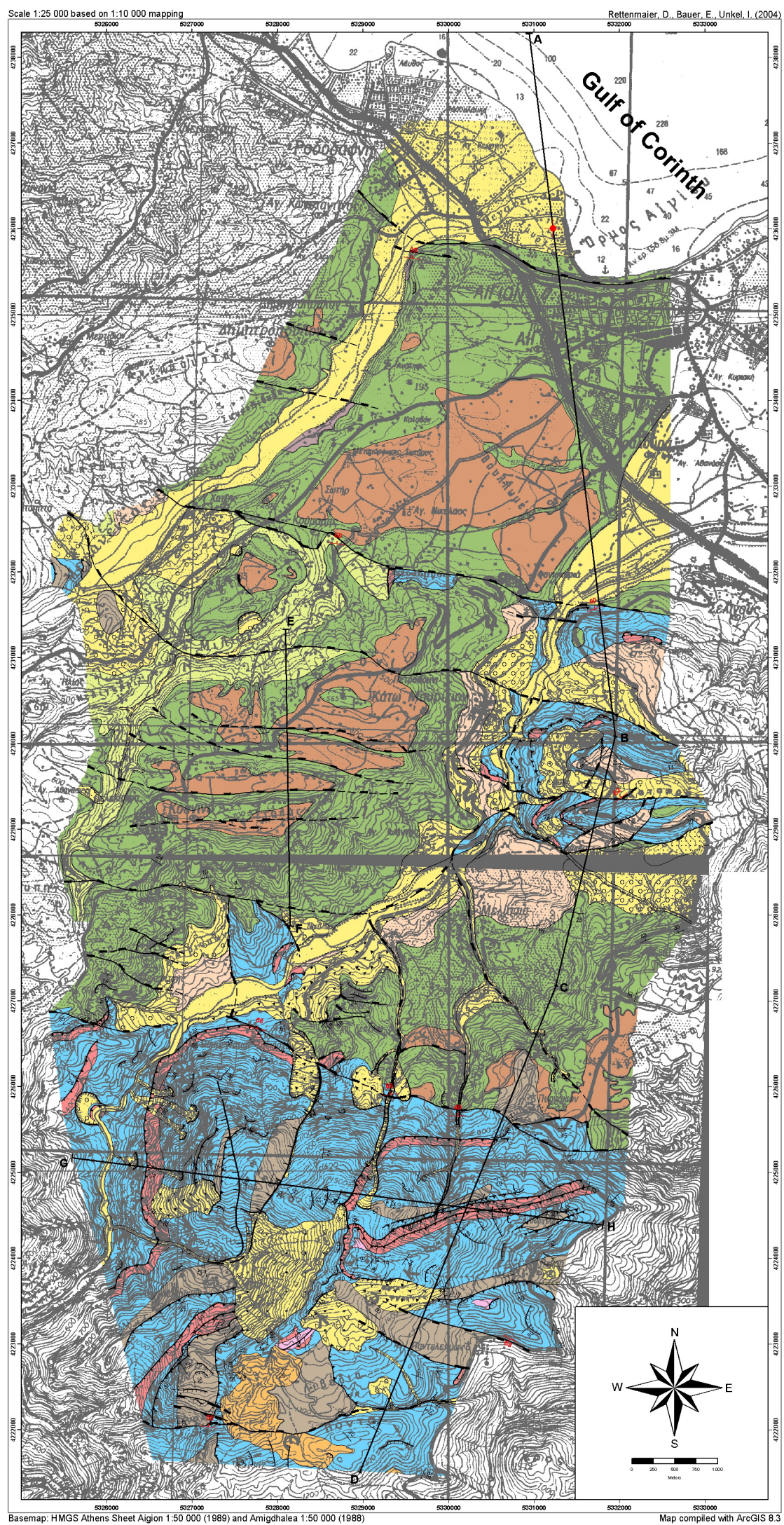

\section{Legend}

Post-alpidic Units

Quarternary

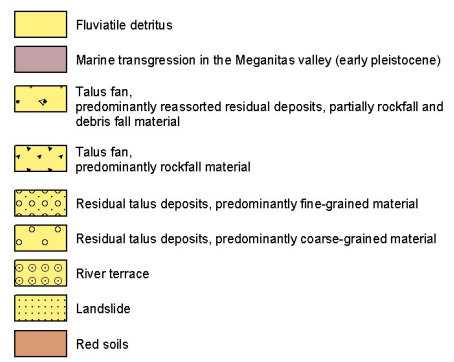

Tertiary

Pliocene-early Pleistocene

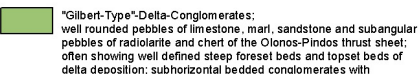

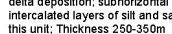

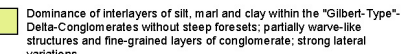

Pliocene

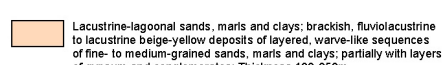

Miocene (?) - Pliocene

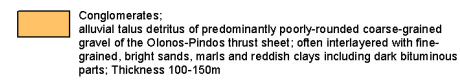

Olonos-Pindos-Thrust Sheet Units Eocene

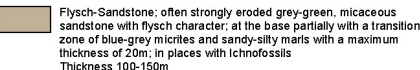

Cretaceous-Tertiary

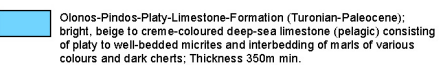

Cretaceous

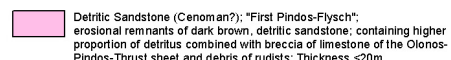

Jurassic-Cretaceous

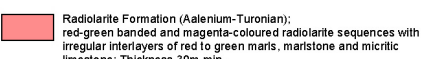

Structural features

- T Thust faut

2.-1.. Thust trutt, assumed

- Normal faut

- - - Normal faut, assumed

- Faut, undefined

- Syncline

TTाT Escarpment

$\sqcup \perp$ Scarf of closing up of valley

$\leftarrow \perp$ scarf of losing up of valley, assumed

- Stratigraphic boundary

- - - Stratioraphic bouray aso

35 Strike and dip of bedding with dip angle

ED.- Strike and dip of fautplane with dip angle

$\rightarrow$ Borenole AII10 
Fig. IV.28: $22 \mathrm{~km}$ North-South cross section A-B-C-D (location see geological map). 


\section{N-S Cross Section Klokos - Aigion \\ Gulf of Corinth, Greece}

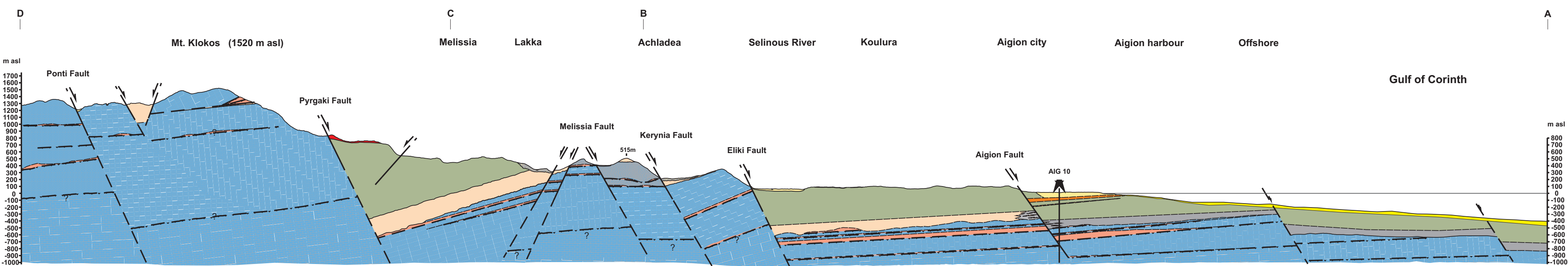

Post-alpidic Units

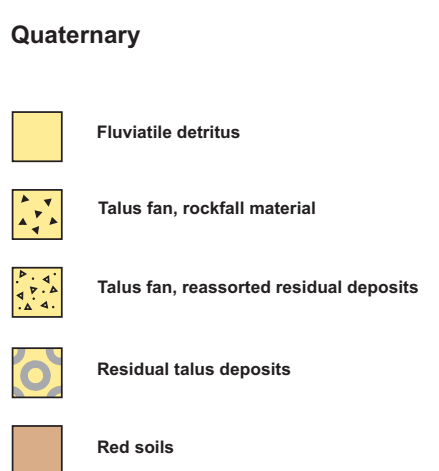

Tertiary

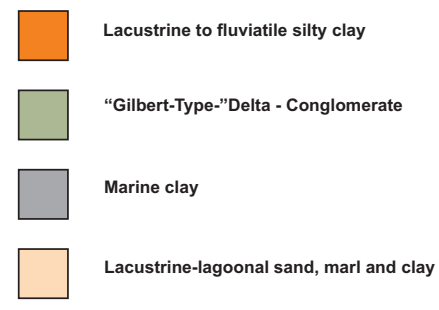

Olonos-Pindos-Thrust Sheet Units

Eocene

$\square$ Flysch-Sandstone

Cretaceous-Tertiary

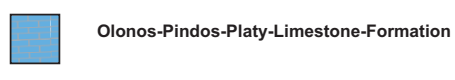

$\square$ Tripolitza-Limestone-Formation

Jurassic-Cretaceous

$\square$ Radioartitformation
Structural Features

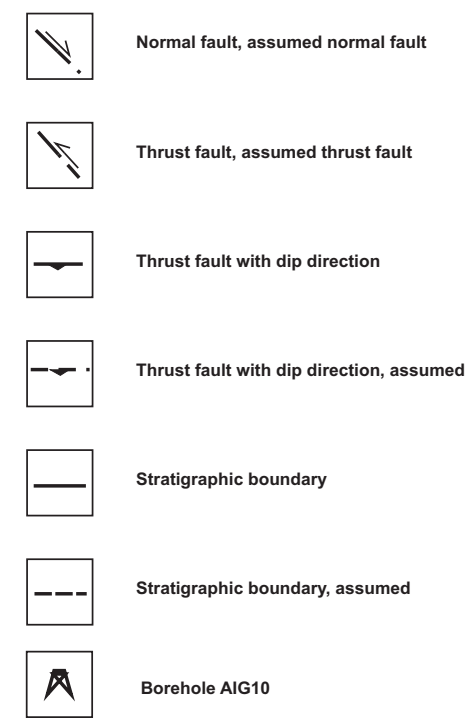




\section{Subsurface investigations}

\section{V.1 Parameter determination from the AIG10 borehole}

\section{V.1.1 Drilling activities}

The International Continental Deep Drilling Project (ICDP) and the EU Project "DGLab-Gulf of Corinth" successfully drilled the AIG10 borehole from July until September 2002 in the harbor of Aigion to a total depth of $1001 \mathrm{~m}$. Fig. V.1 displays the design and drilling process as well as the performance of hydraulic tests in relation to the drilling depth and borehole diameters.

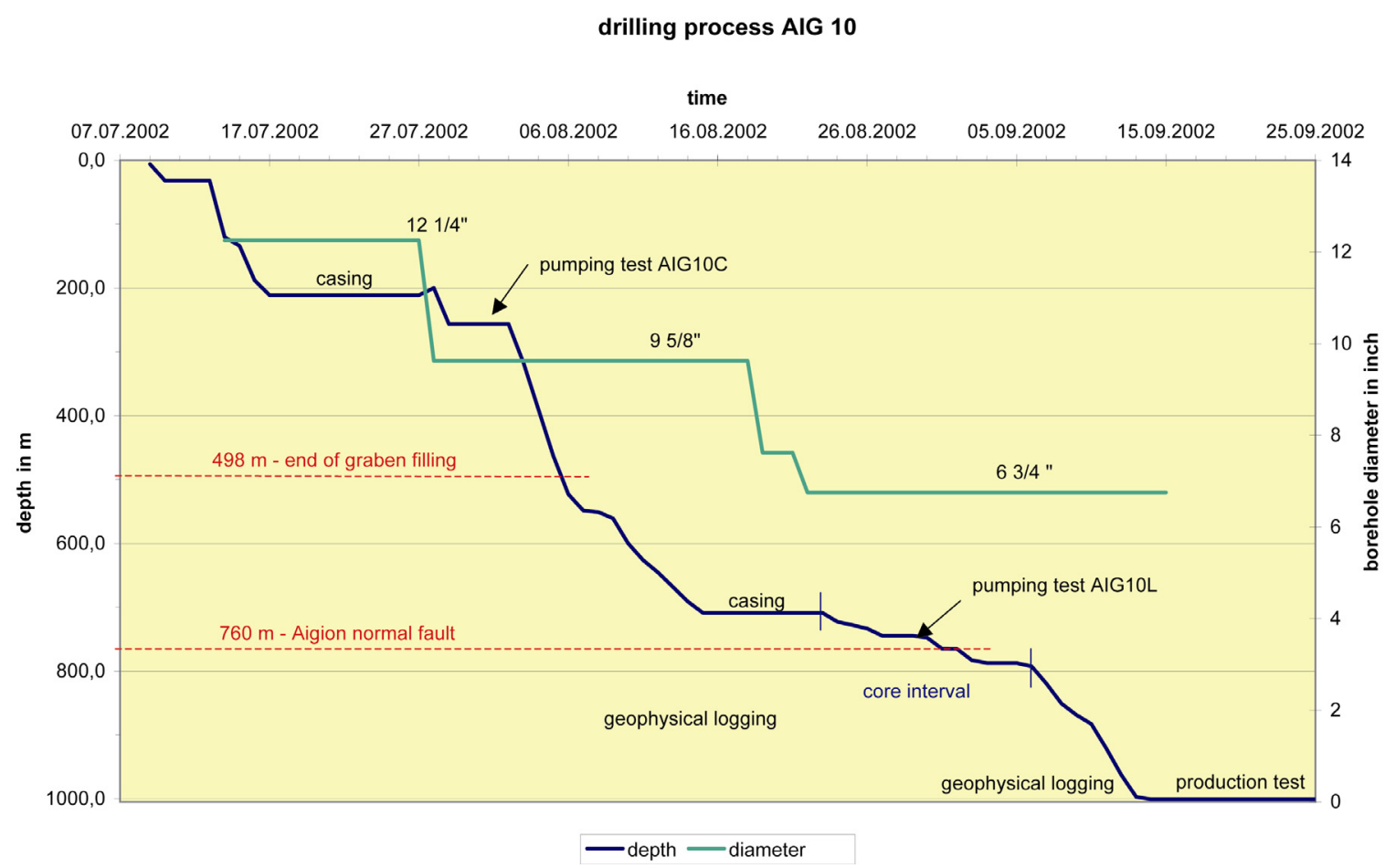

- $\quad 0 \quad-32.00 \mathrm{~m}$ : pilot hole, casing and cementing

- 32.00 - $211.30 \mathrm{~m}: 12 \frac{1}{4}$ “ diameter Rotary Drilling, casing and cementing

- 211.30 - $256.40 \mathrm{~m}: 95 / 8$ " open hole for $1^{\text {st }}$ hydraulic test AIG10C

- 256.40 - 708.08 m : 9 5/8 "diameter Rotary Drilling, casing and cementing

- 708.08 - $744.80 \mathrm{~m}: 6$ 3/4" coring (outer diameter) open hole for $2^{\text {nd }}$ hydraulic test AIG10L

- 744.80 - $787.40 \mathrm{~m}: 63 / 4$ " coring (outer diameter)

- 787.40 - 1001.0 m : 6 3/4" Rotary Drilling

Fig. V.1: History of the drilling process in AIG10. 
The borehole was drilled with a B5R drilling rig in a combination of Rotary Drilling technique and Wireline Diamond Coring technique in order to allow for both, a $12 \frac{1 / 4}{4}$ " and $95 / 8$ " drilling diameter $(0-708.8 \mathrm{~m})$ and high-quality coring in the fault section of the borehole $(708.8-787.4 \mathrm{~m}, 101 \mathrm{~mm}$ core diameter). The relatively large diameter was chosen to enable later full instrumentation. Thirty core runs yielded $71 \%$ core recovery; losses in the upper coring section were due to highly sheared strata. Nevertheless, the main fault zone was fully cored without any loss of material. Coring operations were performed with a bentonite-polymer-freshwater mud at pump rates of 140 to 300 $1 / \mathrm{min}$, with 20 to $30 \mathrm{kN}$ weight on bit and a top drive of 130 to $150 \mathrm{rot} / \mathrm{min}$. The lowermost part of the well between $787.4 \mathrm{~m}$ and the final depth of $1001 \mathrm{~m}$ was rotary drilled $(63 / 4$ " $)$. The well is cased and cemented to $708.4 \mathrm{~m}\left(75 / 8^{\prime \prime}\right)$ therefore the lower part down to $1001 \mathrm{~m}$ is open hole. The inclination of the well is less than $3^{\circ}$ at $330^{\circ}$ azimuth. The bottom-hole temperature measured shortly after drilling stopped was $31^{\circ} \mathrm{C}$.

Geophysical downhole logging was carried out in two campaigns by the ICDP/Operational Support Group when drilling reached $708 \mathrm{~m}$ and $1001 \mathrm{~m}$ (each before casing and cementing). Standard GFZ tools (Mud Parameter, Spektral Gamma, GR-BCS-DIL und MSFL) were used to obtain basic data on borehole condition and wall rock petrophysics. Together with the mud parameters a conventionally temperature log was obtained.

In order to let a temperature log not perturbed by the drilling activities temperature, a Distributed optical fibre Temperature Sensing (DTS) was performed after one year temperature adaptation. Recording interval was $1 \mathrm{~m}$ (Förster et al., 2006).

The in-situ hydrogeological conditions were tested in the conglomerates ( $1^{\text {st }}$ pump test) and in the Olonos-Pindos limestones ( $2^{\text {nd }}$ pump test, hangingwall of the Aigion Fault). A production test was performed in the limestone below the fault which is supposed to be Tripolitza karstic limestone (footwall of the Aigion Fault) (Giurgea et al. 2004). Recognition of stratification of units encountered in the AIG10 borehole is based on an online analysis of well cuttings (0-708.8 m and 787.4-1001 m), online core descriptions (708.8-787.4 m), monitoring of drilling parameters, as well as geophysical well-log interpretation $(0-1001 \mathrm{~m})$.

\section{V.1.2 Drill parameters and cutting analysis}

The B5R drilling rig is equipped with a top drive to turn the drill string with the drill bit at its end. The total force pulling down the hook, the weight on bit (WOB $[\mathrm{kN}]$ ) and the torque $[\mathrm{dNm}]$ as well as the ROP are only some of the obtained drill parameters necessary not only to secure the drilling activities but also gave indications to lithology. Rotary drilling is adapted for soft to medium hardness rocks such as limestones or mudstones but not for siliceous hard rocks as chert and radiolarite but which occurred in the Olonos-Pindos Formation. The consequence was a extremely decrease in ROP from meters per hour to around $2-8 \mathrm{~cm}$ in 15 minutes and the chert and radiolarite was only smeared and not crashed by the drill bit. Also for other depth intervals the ROP and the other drill parameters were useful for indicating the lithology in combination with cutting reading. The table below (Tab. V.1) summarizes the drill parameters which were taken into consideration for the preparation of the litho$\log$ in combination with the online cutting analysis. 
Tab. V.1: drill parameters which were taken into consideration if relevant for the preparation of the litho-log in combination with the online cutting analysis resp. core analysis.

- $\quad$ rounds per minute $(\mathrm{rpm})[1 / \mathrm{min}]$

- pump pressure [Mpa]

- flowrate $[1 / \mathrm{min}]$

- weight on bit (WOB) [kN]

- hookload [kN]

- torque $[\mathrm{dNm}]$

- $\quad$ rotary speed [1/min]
- $\operatorname{mud}$ loss [\%]

- drill mud material

- mud density [r]

- rate of penetration (ROP) $[\mathrm{m} / \mathrm{h}]$

- actual depth [m]

- bottom hole and water temperature

- azimuth (single shot) $\left[^{\circ}\right]$

The braked rock chips (cuttings) at the bottom of the hole are usually only a few $\mathrm{mm}$ to $\mathrm{cm}$ in size. After the estimation of the fine components silt and clay the coarser components were analysed and monitored by the form of composition, grain size, shape, colour, texture, fossils and other properties (Tab. V.2). The grain size and composition were also characterized after DIN 4022 (Deutsches Institut für Normung e.V. DIN; the German national organization for standardization.).

Another way of analyzing stratigraphy is the color coding. In the used Munsell Color Chart each color is given a code of letters and numbers so that they can be compared to other colors in the soil profile. The chart has sets of standardized color chips arranged in rows on several pages. Researchers obtain a color code by comparing the soil color to one of the pages in the book. The purpose of this system is that different researchers cannot make arbitrary descriptions of colors. Using the Munsell Color Charts is preferred by Lemeille et al., 2004 and aid in determining the colors of the cuttings to see the transition between layers. Varieties in cutting- or sequence-color can show differences in lithology, age, chemical, hydrological or geological environment. A detailed cutting report is available at www.icdp-online.de/sites/corinth. This cutting report is interpreted in Unkel, 2003, Lemeille et al., 2004, and Rettenmaier et al., 2004.

Tab. V.2: parameters determined online on cuttings for lithological analysis

- $\operatorname{depth}[\mathrm{m}]$

- detrital components [\%]

- lithology

- Munsell colored [color chart]

- coloured content [\%]

- grain size $\min / \max [\mathrm{mm}]$
- components of sand, gravels, silt, clay [\%]

- shape [angular, rounded, sub-rounded]

- DIN 4022

- fossil content

- preliminary geological classification 


\section{V.1.3 Core analysis}

The B5R drilling rig was equipped with a winch for Wireline Diamond Coring technique to deepen the borehole by way of collecting a cylindrical sample of $6 \mathrm{~m}$ length. After drilling the core into a inner core barrel with a wireline coring bit BRR SK45 a core catcher serves to grip the bottom of the core. With enough torque tension is applied to the drillstring so that the rock under the core breaks away from the undrilled formation below it. The core catcher retains the core so that it does not fall out the bottom of the drillstring. If the core material is too loose it results in core losses which happens mainly in the very fractured parts of the borehole. The core barrel length has a maximum of $6 \mathrm{~m}$, but because of the core loss the core recovery can be less than the barrel length. Another disadvantage of this method is that only unoriented cores can be obtained, but can oriented afterwards by geophysical log interpretation (e.g. UBI, FMI). After the core is catched and tripped out off the inner core barrel using the wireline they were measured by length, image scanned by IFP (Daniel et al., 2004), described in lithology and finally stored in core boxes and were analyzed. Thirty core runs yielded $71 \%$ core recovery. Tab. V.3 specifies the examined core features which were taken into consideration for the preparation of the litho-log of AIG10.

Tab. V.3: relevant parameters determined online on cores for lithological core analysis.

- $\operatorname{depth}[\mathrm{m}]$

- core recovery [m and \%]

- core loss [\%]

- core quality (scale $0-5$ )

- lithology

- general color

- bed boundaries

- dip of bedding

- facies changes

- fissures/fractures/deformation structures
- healing of fissures/fractures

- tectonical features (kinematic indicators, pressure solutions, slickensides, etc.)

- jointing/cleavage (scale 0-5)

- components in [\%]

- cementation/matrix

- fossils

- preliminary geological classification

- drill parameters

- geophysical logs (not online) 


\section{V.1.4 The AIG10 Litho-Log}

\section{V.1.4.1 Corinth graben sediments}

A generalized litho-log is given in Fig. V.2. The succession in AIG10 contains at the top 3.5-m thick argillaceous sandy soil (Tab. V.4). The following Holocene and Pleistocene sequence (Meganitas river deposits and lacustrine deposits) down to $127 \mathrm{~m}$ is characterized by sandy, medium- to fine-grained gravels, intercalated with silty and clayey layers, which can act as aquicludes. These silty clays and marls from $68 \mathrm{~m}$ down to $112 \mathrm{~m}$ are interpreted as lacustrine deposits, regarding to microorganisms. The borehole AIG10 is located in the axis of the Meganitis River. Thus the upper sediments are coarser than those of a $200 \mathrm{~m}$ deep borehole $(\Gamma 1)$, which is located on the edge of the delta $250 \mathrm{~m}$ south of AIG10.

From $127 \mathrm{~m}$ to $388 \mathrm{~m}$, stiff conglomerates were encountered in the borehole with alternating layers of sand and clay as well as marine intercalations. This $261 \mathrm{~m}$ thick sequence consist mainly of wellrounded limestone, marl and sandstone detritus as well as subangular radiolarites and cherts eroded from the Olonos-Pindos Formation, representing delta environment.

A clayey and sandy transition to marine sediments occurs below this unit, which is underlain by a dark-gray marine clay to a depth of $496 \mathrm{~m}$. The Pleistocene calcareous, fat clay is less silty and contains fossils and nannoplankton, evaluating the age of this sequence. This marine syn-rift deposit could be related to a marine high stand [Mis 5e] in the late Pleistocene. The dark-gray clay is underlain by a reddish clay sequence, marking the transition to a following radiolarite succession.

The Corinth graben as recorded in the AIG10 borehole comprises at least eight units (Tab. V.4). Two assumptions can be proposed for an interpretation of the syn-rift deposits in terms of age. In the first assumption, all the fine-grained to clayey intercalations (intermediate markers) are matching with the short marine high stand MIS 9, 7, 5 and 3 in the general conglomeratic sedimentation (Lemeille et al., 2004). In the second assumption, all the intermediate markers would match with the minor and major high stands of MIS 5 and MIS 3. Continuative analysis in detail about the recent synrift deposits from the Aigion hangingwall and dating is located in Lemeille et al., 2004.

Tab. V.4: Recent synrift sediment units encountered in AIG10 after Lemeille et al., 2004.

\begin{tabular}{lrl}
\hline - Unit 1: & $0-3.5 \mathrm{~m}$ & continental superficial deposits and soil \\
- Unit 2: & $3.5-68 \mathrm{~m}$ & holocene transgression \\
- Unit 3: & $68-112 \mathrm{~m}$ & lacustrine deposits \\
- Unit 4 & $112-127 \mathrm{~m}$ & fluvio-torrential conglomerates \\
- Unit 5: & $127-153 \mathrm{~m}$ & upper alternations \\
- Unit 6: & $153-330 \mathrm{~m}$ & stiff conglomerates \\
- Unit 7: & $330-388 \mathrm{~m}$ & lower coarse-fine alternations \\
- Unit 8: & $388-496 \mathrm{~m}$ & basal clay unit \\
\hline
\end{tabular}




\section{V.1.4.2 Olonos-Pindos Formation}

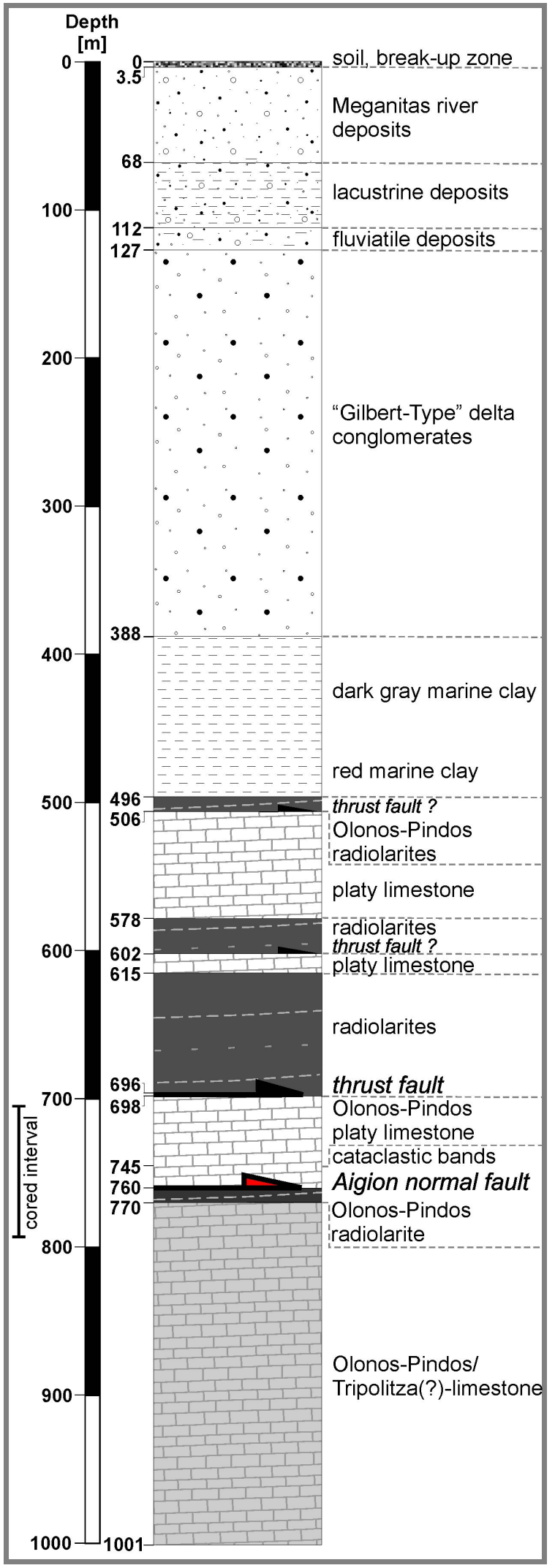

Fig. V.2: Generalized Litho-Log of AIG10
The Olonos-Pindos Formation is encountered at $496 \mathrm{~m}$ depth with sharp-edged green and red radiolarites cuttings of gravel size in the Olonos-Pindos Radiolarite Formation (Fig. V.2).

This change in lithology is obvious on the geophysical $\operatorname{logs}$ as well as from drilling parameters such as the decrease of the rate of penetration (ROP). The dense radiolarite has a thickness of $10 \mathrm{~m}$ and is underlain by limestones intercalated with silicious marls, analyzed from cuttings. With increasing depth, the lithology then repeatedly changes from limestone to radiolarite and marlstone again. It has to be assumed that the younger Jurassic radiolarite, encountered from $496 \mathrm{~m}$ down to $506 \mathrm{~m}$ is overthrusted onto the older Cretaceous platy limestones.

Similar to this assumption are the successions of radiolarite at $578 \mathrm{~m}-602 \mathrm{~m}$ and $615 \mathrm{~m}-$ $696 \mathrm{~m}$. Because of the heterogeneity of the sequence between the depth of $506 \mathrm{~m}$ and 696 $\mathrm{m}$, it can be assumed that several tectonic contacts and folds in smaller scales exist. A detailed analysis of the succession from $450 \mathrm{~m}$ to $705 \mathrm{~m}$ bsl based on the correlation of cuttings and geophysical logs is given in Fig. V.3. The radiolarite is often accompanied by marls and limestone intercalations. At 513-524 $\mathrm{m}$ clayey Flysch sandstone is encountered in the log, characterized by a strong increase of the gamma ray and the slowness-p wave which is the reciprocal value of $\mathrm{p}$-wave-velocity $\mathrm{Vp}$. The following sequence down to $579 \mathrm{~m}$ consists of a heterogeneous succession of marly limestones and platy limestones, partly with radiolarite intercalations. Solid radiolarite then is marked through a decrease of the gamma log and the slowness p-wave down to $602 \mathrm{~m}$. 


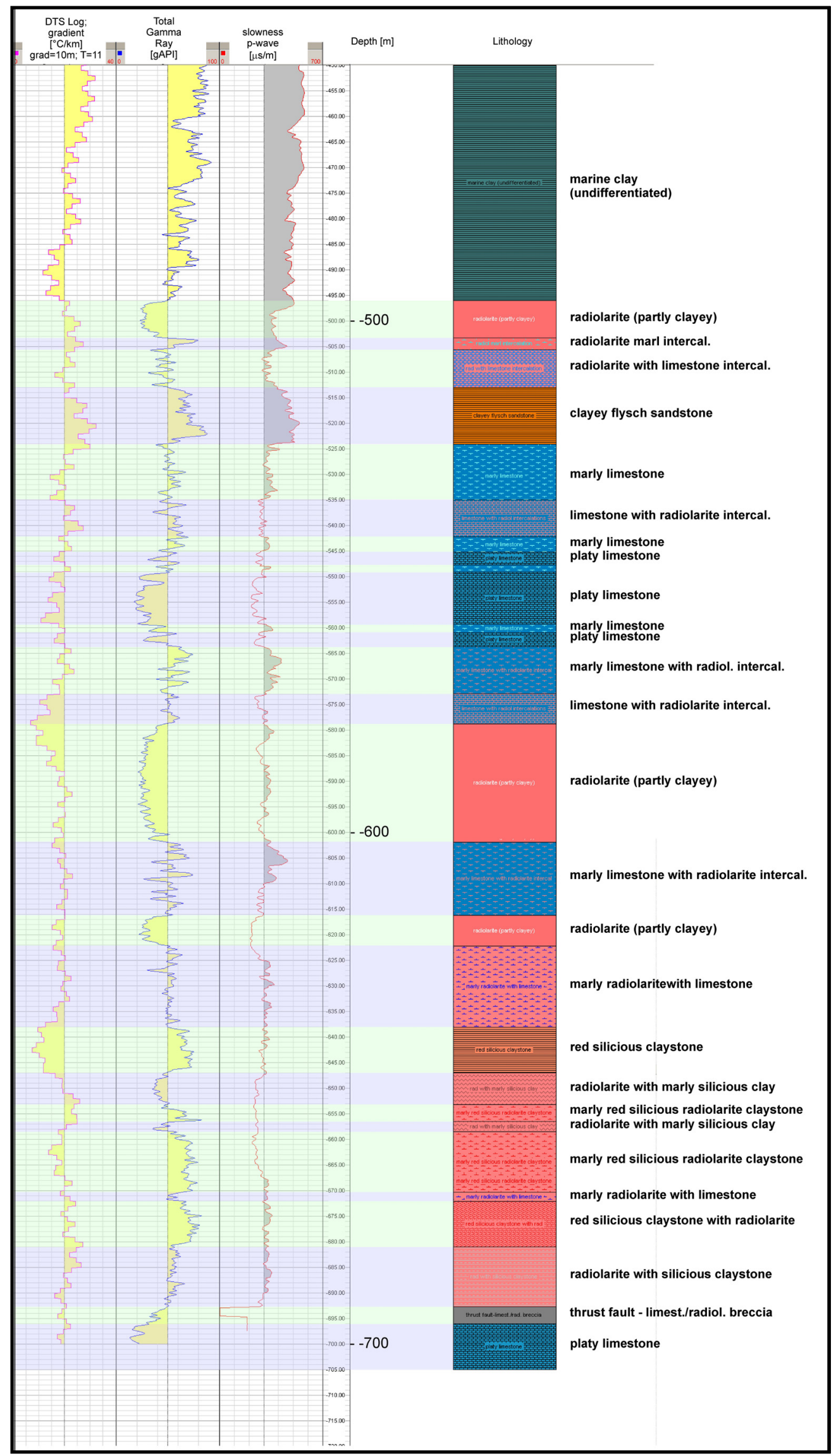

Fig. V.3: Detailed succession from $450 \mathrm{~m}$ down to $705 \mathrm{~m}$ depth in AIG10. The cutting analysis is correlated with the temperature gradient, total gamma log, and slowness $\mathrm{p}$-wave $1 / \mathrm{v}_{\mathrm{p}}$. 
The characterization of the whole sequence from $579 \mathrm{~m}$ down to $693 \mathrm{~m}$, consisting of radiolarite with different marl, limestone, and partly clayey intercalations, corresponds to the Radiolarite Formation confirmed by the surface investigations. At $693 \mathrm{~m}$, a $3 \mathrm{~m}$ thick breccia of limestones and radiolarite points to a thrust fault where the Radiolarite Formation is overthrusted on the platy limestones of the Olonos-Pindos Formation. Another indication of the thrust zone is the high content of calcite cuttings, assuming recrystallization and higher water circulation in this zone.

Compressive features such as small-scale faulted folds or the slipping of less competent intercalations in the succession of the Olonos-Pindos Formation are typical for the lithology and were explored on the surface as well as on the cores from $698 \mathrm{~m}$ down to $745 \mathrm{~m}$. However, such small-scale features cannot be responsible for the older radiolarite being placed on the younger platy limestones. These results are consistent with observations made on outcrops south of Aigion, where thrust-fault zones show several alternating thrust planes. The well-logging data as Gamma Ray at these particular depths also support this interpretation (Fig. V.3 and Fig. V.18).

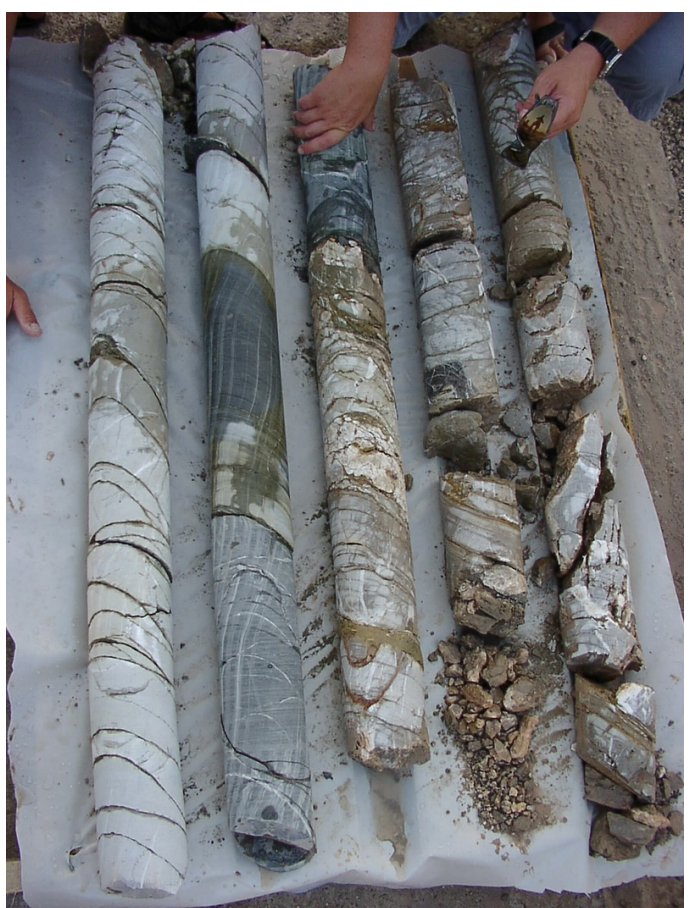

a)

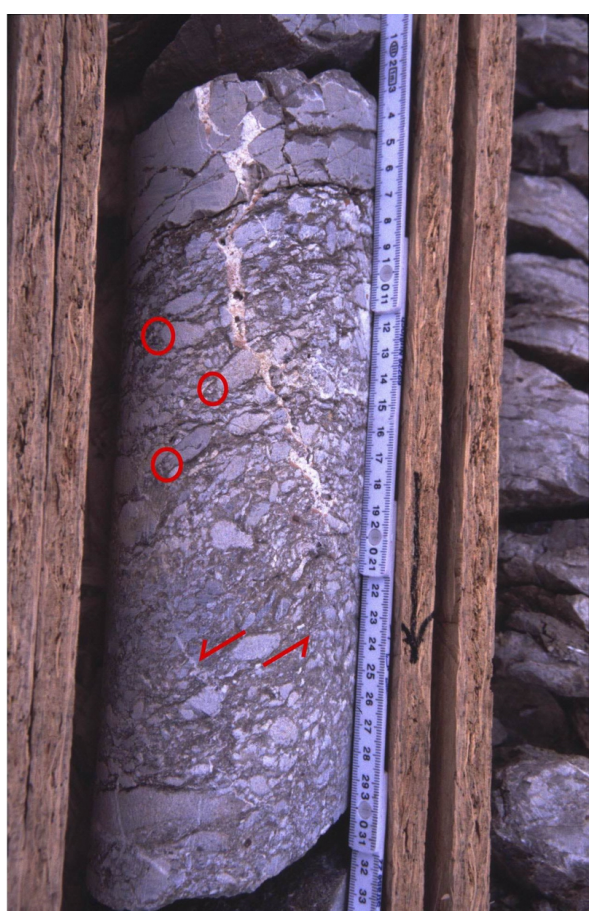

b)

Fig. V.4: Core runs and kinematic indicators. a) Core runs 6-10 $(727-735 \mathrm{~m})$ as a part of open hole for the pumping test AIG10L. The cores show beige colored platy and well stratified micrites and marlstones typical for the Olonos-Pindos Platy Limestone Formation. The dip of bedding is $30^{\circ} \mathrm{NW}$ and is coherent with the alpidic thrust direction. b) Below $745 \mathrm{~m}$, the Olonos-Pindos platy limestone shows several cataclastic bands. In Core Run 13 (CR13 from 745.8-746.1 m) the $1^{\text {st }}$ band is characterized by a well-cemented cataclastic zone with healed calcite veins showing features of pressure solutions and pressure shadows (red circles), representing microkinematic indicators. After the orientation of the core one can recognize normal fault kinematics in north direction (red arrows).

Below the thrust-fault zone in $698 \mathrm{~m}$, the Olonos-Pindos Platy Limestone Formation was identified by cuttings of light-brown or greenish-gray limestone and marlstone as well as red marl and siliceous 
marlstone. The first core taken at a depth of $708.8 \mathrm{~m}$ confirms the typical character of the wellfractured, slab-shaped platy limestones (Fig. V.4). The dip of bedding of the platy limestone is SE and E possibly indicating a NW-verging thrust progradation.

Below $745 \mathrm{~m}$, the Olonos-Pindos platy limestone shows several cataclastic bands (Fig. V.6). The first band (at 745.7-746.5 m) is characterized by a well-cemented cataclastic zone with healed calcite veins. Calcite crystals show features of pressure solutions and pressure shadows, whose textures can be interpreted as microkinematic indicators. We interpret this as dip-slip displacement/normal faulting. Another $70-\mathrm{cm}$ thick cataclastic band with less well healed veins and shear structures was identified in core at $748 \mathrm{~m}$. In contrast to the first two bands, the third band from 754-755 m shows a less compact brecciated zone with open fractures, voids, and geodic cavities, which are filled only partly with calcite. It can be assumed that this cataclastic band is younger than the two previously described because of the stronger brecciated zones and different healed veins. These shear bands and cataclastic zones obviously are part of a major normal fault zone, indicating the Aigion fault.

The fourth very strong brecciated cataclastic band was encountered at $756 \mathrm{~m}$ and is $4-\mathrm{m}$ thick. This band separates well-fractured platy, micritic limestone from highly fractured radiolarite. At $760 \mathrm{~m}$ the contact between the hangingwall (limestone) and the footwall (radiolarite) dips approximately 55-60 to the north (Fig. V.5). This values would be coherent with the dip of the Aigion fault plane on the surface and a distance of $470 \mathrm{~m}$ to the well. The angle between the bedding of the stratigraphic sequences, dipping SE and E, and the fault plane, dipping $\mathrm{N}$, is between $80-100^{\circ}$ and is confirmed by the interpretation of core analysis by Daniel et al., 2004.

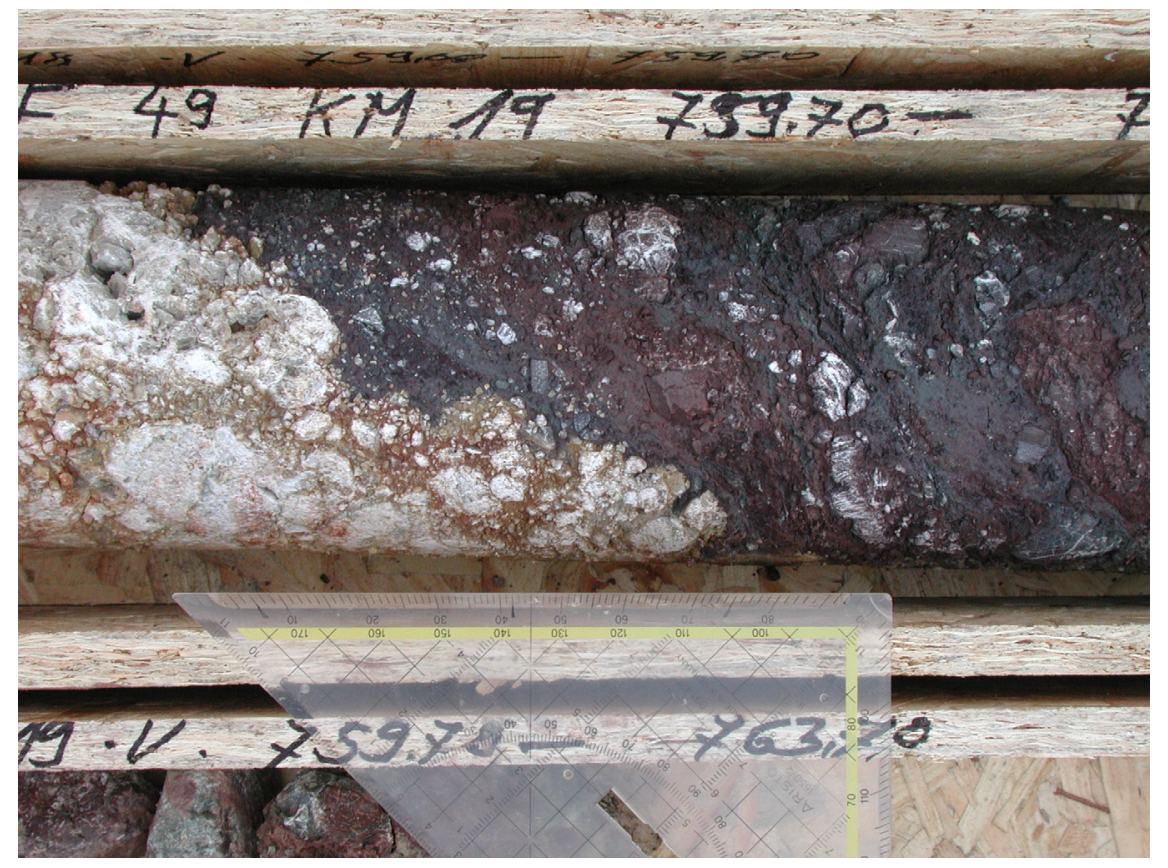

Fig. V.5: Core run 19 from 759-763 m, showing the contact between the hangingwall (limestone) and the footwall (radiolarite) of the Aigion normal fault in $760 \mathrm{~m}$ depth. 


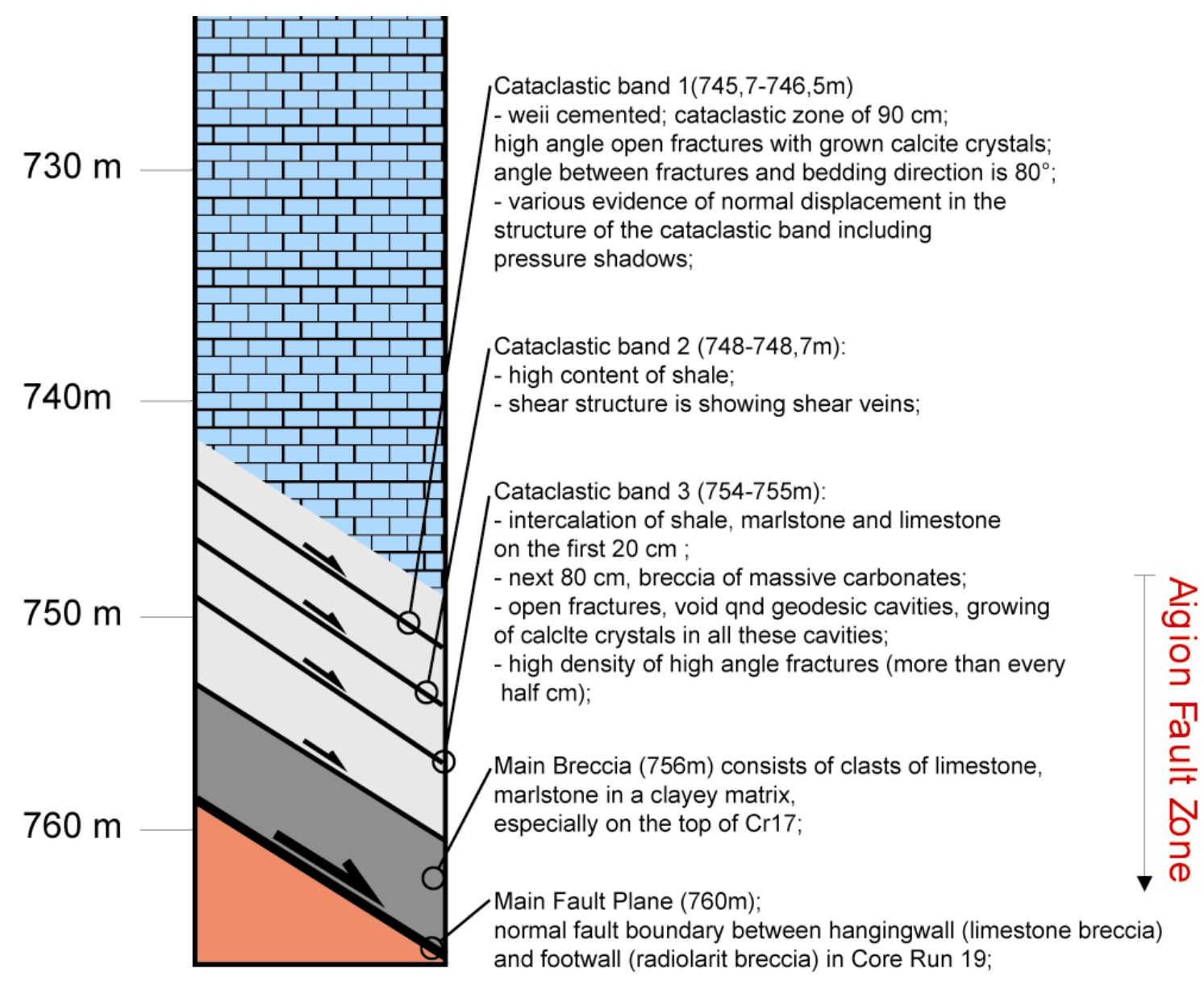

Fig. V.6: Interpretation of core analyses (Cr, core run) in the Aigion fault zone.

After crossing the fault zone, an increase of water pressure from 5 bar up to $>10$ bar was measured. The highly fractured and brecciated radiolarite as well as the high influx of water caused core losses so that the transition from radiolarite to the underlying limestone could not be located in the cores. However, the geophysical logs indicate the contact to the limestone at $770 \mathrm{~m}$.

The cores from $774 \mathrm{~m}$ to $787.4 \mathrm{~m}$ (end of coring) show that these limestones differ from the micritic limestones of the upper parts of the drilled sequence. Whereas the Olonos-Pindos platy limestones are micrites (pelagic deep sea limestone) the limestones from $770 \mathrm{~m}$ downwards are more coarsely crystalline and could be named as Dolomites and Calcarenites. They are light gray with a high content of well developed calcite crystals. Intercalations of marl and marlstone are very rare. Only some thin, black and marly intercalations were observed. The rock is very porous and has open fractures, large voids, cracks and dissolution structures. The lower limestone show no macroscopic fossils. Although the HCL reaction on the core samples was not very strong or nearly absent thin section analysis and further investigations to analyze the dolomitic content of the samples would help to classify these limestones more precisely.

The cores and the hydraulic behavior of the deeper intervals down to $1001 \mathrm{~m}$ suggest karstification and karstic water-flow conditions. Because of the high influx of water into the well and the high water 
pressure, the coring had to be stopped at $787.4 \mathrm{~m}$ and rotary drilling was continued to a total depth of $1001 \mathrm{~m}$. Cuttings from the last depth interval did not reveal any difference in lithology in relation to the first cuttings compared with the last cores. Even though the analysis of cuttings is not as precise than cores presumably no stronger changes in the lithology of the limestone appears from 787.4 down to the total depth of $1001 \mathrm{~m}$.

The stratigraphic assignment of the lower limestone from $770-1001 \mathrm{~m}$ is not clear because the thickness of the Olonos-Pindos nappe overlying the Tripolitza nappe can vary. At the leading edge of the thrust sheets in the W near Patra where the Tripolitza unit plunges under the Pindos unit, the Olonos-Pindos Formation has less thickness. To the E and SE of the Peloponnesus, the tectonic windows (Parnon, Taygetos) show Tripolitza limestone in contact with the Olonos-Pindos limestone . The Olonos-Pindos Formation at $496 \mathrm{~m}$ in the AIG10 borehole has a succession of $274 \mathrm{~m}$ down to 770 $\mathrm{m}$ including several thrust faults and a normal fault at $760 \mathrm{~m}$. Taking the $231-\mathrm{m}$ thick lower limestone (770-1001 m) into account, the sequence would be 505-m thick. Therefore, it is possible that the lower 231-m thick limestone could belong to the Olonos-Pindos Formation.

Otherwise, from the lithologic characterization, karstification, and rock properties, however, it is likely that this limestone is part of the Tripolitza unit. If the latter is true, then the sequences must be separated by a main thrust fault at approx. $770 \mathrm{~m}$. The existence of such a thrust fault is supported by the core loss resulting from well brecciated Olonos-Pindos radiolarite and limestones at that depth. It is concluded that I assume for the conceptual hydrogeological model and the numerical model well karstified Tripolitza limestones encountered from $772 \mathrm{~m}$ at least to the borehole depth of $1001 \mathrm{~m}$. The total thickness of the karst is unidentified but is known to be $>1000 \mathrm{~m}$. For this reason the karst is suppose to range further down to the lowest model boundary bc7 which is located in $1200 \mathrm{~m}$ bsl (Chapter VII). 


\section{V.2 Hydrogeological investigations}

\section{V.2.1 Hydraulic tests and hydrochemical analysis}

For the determination of hydraulic parameters in the vicinity of the major normal fault zone of Eliki, pumping tests including the recovery phase were performed in the Selinous valley (E2-EQ1, Rettenmaier, 2002) and Meganitas valley (PB3-BP12, Bauer, 2004). These studies helped to understand possible connections between fluid circulation and hydraulic conductivity of the fault zones in-between the Platy Limestones (Selinous) as well as the hydraulic conditions in the Alluvium of river sediments and the marine lagoonal deposits which are necessary hydrogeological input data for the hydrogeological conceptual and numerical model. The locations are cited in Fig. II.2. The time dependent drawdown and recovery of the groundwater level and temperature was automatically registered with a Diver ${ }^{\circledR}$ by Van Essen Instruments (Eijkelkamp) and the data were evaluated with the Aquifer Test Analysis Software "AQTESOLV for Windows 2.5-Professional". All hydraulic tests were performed following the instructions of the German Technical and Scientific Association for Gas and Water (DVGW, 1995).

AQTESOLV for Windows is a tool for hydrogeologists generated by Duffield, G.M., 1999 (Hydro SOLVE, Inc.) for analyzing pumping test, recovery test, and slug test data. It provides a suite of analytical solutions for determining aquifer properties by visual and automatic curve matching methods for confined, unconfined, leaky, and fractured aquifer types. The visual curve matching feature analyses the data by the traditional method of matching the time-drawdown (-recovery) data with the type-curves (or straight lines) by hand on the screen. In contrast the automatic curve matching feature uses a non-linear weighted least-squares parameter estimation algorithm and minimizes the position errors of the data- and type-curves. Additionally the automatic feature provides statistical information about the "best fit" of the curves and computes the standard errors of the estimated parameters. This allows the user to estimate the accuracy of the parameters and to define similar intervals of hydraulic behavior.

For the data analysis of the performed hydraulic tests both matching methods were used and compared which each other. All solutions provided by AQTESOLV were applied to each hydraulic test data set, displaced in Tab. V.5. At first the results were screened due to "trial and error" and the absolutely nonfitting results were excluded. The better fitting results then were analyzed in detail by the best solution and type curve fitting. For the theoretical background of AQTESOLV for Windows see Duffield, 1999 or the User's Guide by HydroSOLVE, Inc. at www.aqtesolv.com. As well not all employed processes are listed in the following chapter and only the very best results are discussed in context of the input for the hydrogeological conceptual and numerical model. Continuative information about the detailed analysis is given in Rettenmaier, 2002, Unkel, 2003, and Bauer, 2004. 
Additionally the pumped water of all hydraulic tests were analyzed concerning the hydrochemical contents and were compared to the results of more than 90 springs and wells sampled in the study area. Water samples were taken following the instructions of the German Technical and Scientific Association for Gas and Water (DVGW, 1992). Besides the Cations $\mathrm{Ca}^{2+}, \mathrm{Mg}^{2+}, \mathrm{Na}^{+}, \mathrm{K}^{+}, \mathrm{Mn}^{+}, \mathrm{NH}_{4}^{+}$ and total $\mathrm{Fe}$ the samples were examined for the Anions $\mathrm{Cl}^{-}, \mathrm{NO}_{3}{ }^{-}, \mathrm{SO}_{4}{ }^{2-} \mathrm{HCO}_{3}{ }^{-}$(all in [mg/l]) and for the trace elements $\mathrm{SiO}_{2}, \mathrm{PO}_{4}, \mathrm{~F}, \mathrm{Li}, \mathrm{As}, \mathrm{Br}, \mathrm{Sr}, \mathrm{Sb}, \mathrm{Hg}$ and $\mathrm{U}$ (in [ppm]). Further springs and wells were electrometrical measured in-situ in terms of flux (in $[1 / \mathrm{min}]$ ), temperature (in $\left[{ }^{\circ} \mathrm{C}\right]$ ), electric conductivity (in $[\mu \mathrm{S} / \mathrm{cm}]$ ), $\mathrm{pH}$-value (pH-meter), and oxygen content (in $[\mathrm{mg} / \mathrm{l}]$ and $[\%]$ ). These hydrochemical investigations give evidence of the origin and mean residence time of the groundwater and helped in understanding the movement and classification purposes of the groundwater. They are as well important data for developing the hydrogeological conceptual model.

Tab. V.5: Used Type Curve solutions provided by AQTESOLV for Windows 2.5-Professional modified after Duffield, G.M., 1999 (Hydro SOLVE, Inc.)

\begin{tabular}{|c|c|}
\hline \multirow{5}{*}{$\begin{array}{l}\text { Confined Aquifer } \\
\text { Solutions }\end{array}$} & Theis (1935) type curve solution \\
\hline & Cooper-Jacob (1946) straight line solution \\
\hline & Papadopulos-Cooper (1973) for large-diameter pumping wells \\
\hline & Hantush (1962) type curve solution for a wedge-shaped aquifer \\
\hline & Theis (1935) for drawdown in a pumping well during step drawdown tests \\
\hline \multirow{5}{*}{$\begin{array}{l}\text { Unconfined Aquifer } \\
\text { Solutions }\end{array}$} & Theis (1935) type curve solution \\
\hline & Cooper-Jacob (1946) straight line solution \\
\hline & Neuman (1974) type curve solution \& Quick Neuman type curve solution \\
\hline & Streltsova (1988) type curve solution for piezometers \\
\hline & Moench (1997) type solution for a large-diameter pumping wells \\
\hline \multirow{3}{*}{ Leaky Aquifer Solutions } & Hantush-Jacob (1955) type curve solution (no storage in aquitard) \\
\hline & Hantush (1960) type curve solution (storage in aquitard, early time) \\
\hline & Moench (1985) solution for large-diameter well, storage in aquitard \\
\hline \multirow{2}{*}{$\begin{array}{l}\text { Fractured Aquifer } \\
\text { Solutions }\end{array}$} & $\begin{array}{l}\text { Moench (1984) type curve solution for a double-porosity fissured aquifer } \\
\text { with slab-shaped matrix blocks }\end{array}$ \\
\hline & $\begin{array}{l}\text { Moench (1984) type curve solution for a double-porosity fissured aquife } \\
\text { with spherical shaped matrix blocks }\end{array}$ \\
\hline
\end{tabular}




\section{V.2.1.1 Selinous valley testing}

The test site for the pumping tests in the Selinous valley $4 \mathrm{~km}$ south of Aigion was chosen due to the geological situation and the fact that there is a pumping well available which is used for plant irrigation. The well is $90 \mathrm{~m}$ deep and, after some meters of fluviatile quaternary sediments, completely in the Olonos-Pindos Platy Limestone Formation proved by limestone cuttings (Nikas, IGME, personal communication and). The simplified geologic cross section (Fig. V.7) shows the location of the pumping well EQ1 and in a distance of $13 \mathrm{~m}$ the observation well E2 approx. $80 \mathrm{~m}$ south of the Eliki fault. A second observation well is located at the western valley in $116 \mathrm{~m}$ distance to EQ1. The test situation is not only adapted for evaluating the hydrogeological parameters of the platy limestones but also for investigating of the hydraulic behavior of a major normal fault. The Eliki fault in the north of the site strikes with $63^{\circ} \mathrm{NE}-\mathrm{SW}$ and dips very steep with an average value of $66^{\circ} \mathrm{NNW}(333 / 60)$ (Fig. IV.24). Therefore the hydraulic behavior should be visible in the pumping test results showing positive boundary conditions (in the case that groundwater flow occurred from the conglomerates of the hangingwall through a permeable fault plane) or negative boundary conditions (in the case of a noflow boundary when the fault plane reacts as a hydraulic barrier).

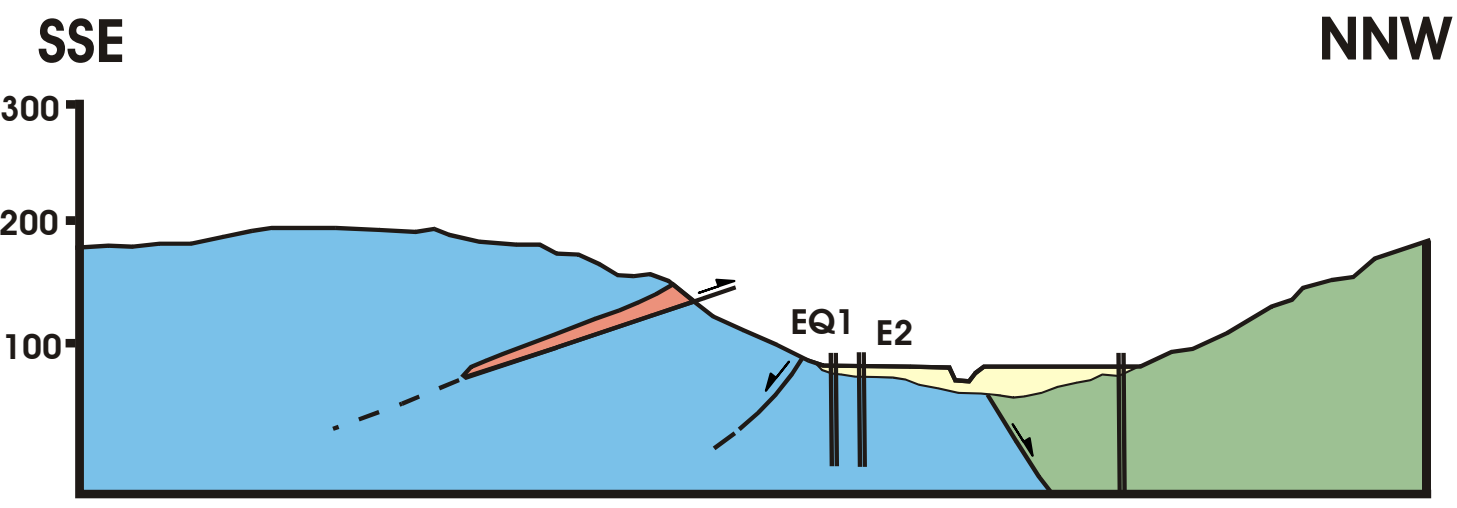

Fig. V.7: Schematic NNW-SSE cross section of the Selinous pumping test site (Rettenmaier, 2002).

The hydraulic test in the Selinous valley was performed under unsteady pumping test conditions. The pumping rate of EQ1 was $290 \mathrm{~m}^{3} / \mathrm{h}$ and took $72 \mathrm{~h}$ with $30 \mathrm{~h}$ drawdown and $42 \mathrm{~h}$ recovery (Fig. V.8). The test was run first at the end of the dry summer season in 2001 when pumping was still ongoing and the groundwater level was dramatically low. Nikas (pers.com.) specified for the still-water-level (SWL) in this region 7-11 m below surface level ( $\mathrm{m} \mathrm{bsl}$ ). The groundwater level at the beginning of the pumping test in 2001 was $38,63 \mathrm{~m}$ bsl in EQ1 and 38,59 $\mathrm{m}$ bsl in E2 and the maximum drawdown was $2,22 \mathrm{~m}$ in E2. For this reason the test results were controlled by a rerun in December 2003 after the Greek irrigation period when groundwater level reaches the SWL (Bauer, 2004). In this test we started the pumping test at $8,76 \mathrm{~m}$ bsl in EQ1, 8,94 $\mathrm{m}$ bs1 in E2 and the maximum drawdown was $5,61 \mathrm{~m}(\mathrm{E} 2)$ and $4,92 \mathrm{~m}(\mathrm{E} 3)$. 


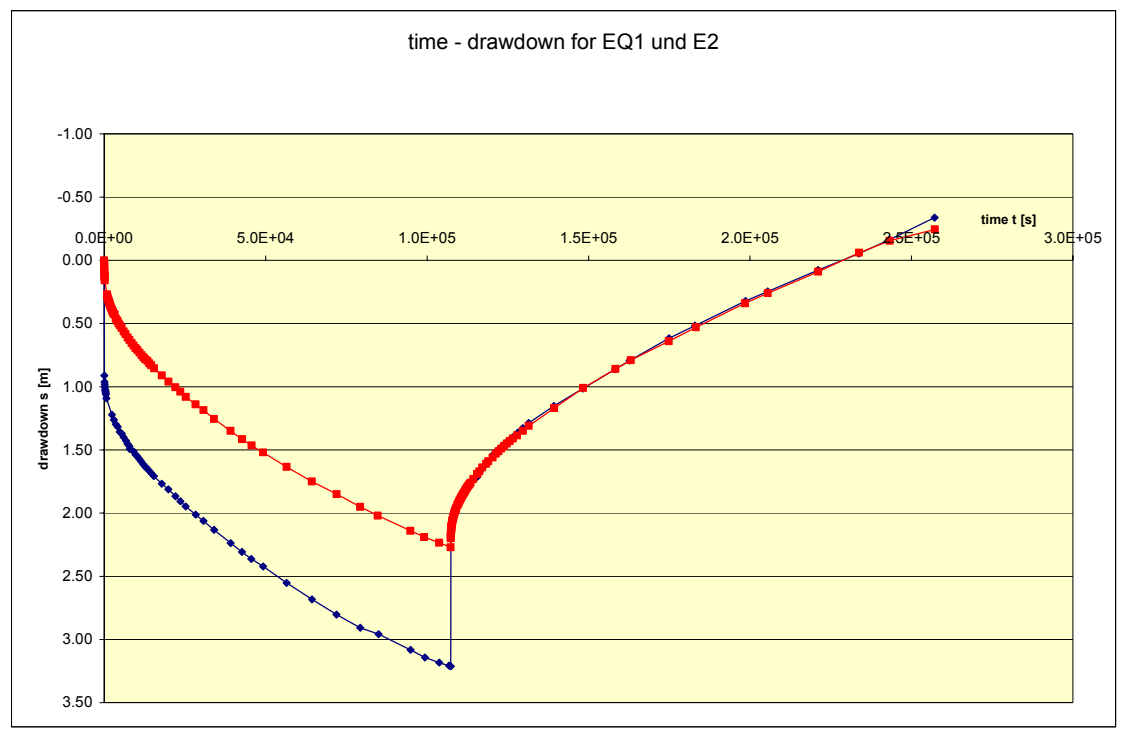

Fig. V.8: Time-depended drawdown and recovery phase for the Selinous test. EQ1 (blue): pumping well; Piezometer E2 (red): observation well; test duration: $61,4 \mathrm{~h}$ with $30 \mathrm{~h}$ pumping rate and $31,4 \mathrm{~h}$ recovery phase; the step of EQ1 can be explained through well-losses after switching off the pump with a resulting drop of the water column in the borehole casing (Rettenmaier, 2002).

The data processing for the Olonos-Pindos platy limestones in Fig. V.9a,b show that the very best fitting is the Moench fractured approach (AQTESOLV ${ }^{\circledR}$ ) (Moench, 1993a,b). The average hydraulic conductivity is determined to $\mathrm{k}_{\mathrm{f}}=2 \times 10^{-3} \mathrm{~m} / \mathrm{s}-2 \times 10^{-4} \mathrm{~m} / \mathrm{s}$ and a very low matrix-permeability of the micritic limestones $\left(\mathrm{k}=1 \times 10^{-9} \mathrm{~m} / \mathrm{s}\right)$ is quantified. The better fitting of the Moench solution for fractured aquifer assuming slab-shaped matrix blocks in accordance to spherical shaped matrix blocks give evidence that the orthogonal joint system detected at the surface is due to release joints and is not that much developed in depth. The consequence then is that in depth the slab-shaped and platy character is dominant and horizontal flow prevails.
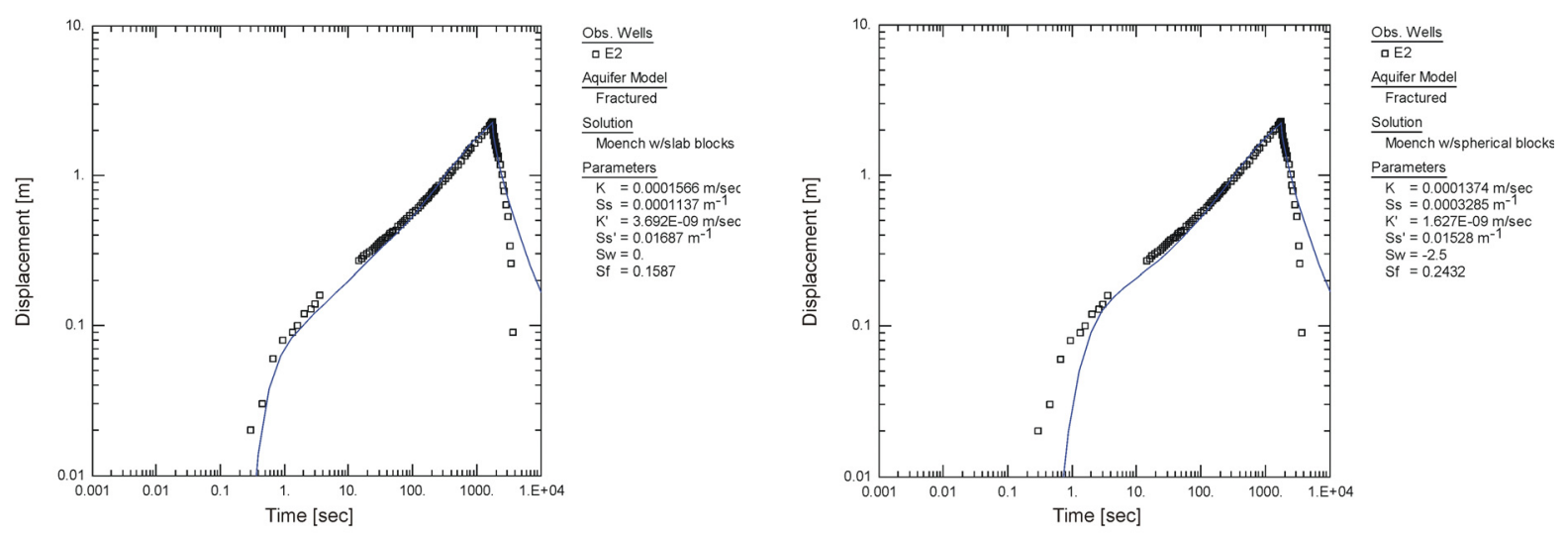

Fig. V.9: Processing of the Selinous test results for Olonos-Pindos platy limestones. The very best fitting is generated by the Moench fractured approach for a) fractured aquifer conditions assuming slab-shaped matrix blocks in accordance to b) spherical shaped matrix blocks. 
Otherwise vertical leakage through semipermeable layers are probable. Beside the well jointed Olonos-Pindos platy limestones, less permeable sandstones or radiolarians can be encountered. Because of the multiple imbricates, confined aquifer conditions are less expected and is confirmed by the non-fitting solutions for confined aquifers (Rettenmaier, 2002). Based on the above mentioned heterogeneities, half-confined or half-unconfined aquifer conditions are presumably and were confirmed by the second pumping test in 2003 (Bauer, 2004).

Furthermore positive boundary conditions due to the Eliki fault could not be proved. The Eliki fault seem to act like a hydraulic barrier, fact which was confirmed through the piezometric measurements to the north of the Eliki fault in 2002. The results suggest rather no-flow boundary conditions north of the well with average transmissivities of the formations on the order of $0.002-0.02 \mathrm{~m}^{2} / \mathrm{s}$ within the fractured character of the limestones.

The second pumping test made in Selinous river valley when the first was prepared in the dry summer season of 2001with very high water catchments and very low groundwater levels in the Olonos-Pindos limestones had the goal to expose possible differences between the results of extremely different groundwater levels. A Transmissivity in the order of $6.9-9.4 \times 10^{-3} \mathrm{~m}^{2} / \mathrm{s}$ and a average hydraulic conductivity of the fractures of $1.5 \times 10^{-4} \mathrm{~m} / \mathrm{s}$ in the well EQ1 is derived from this test for the OlonosPindos platy limestones. It is interesting to note that the pumping test runs were in two different phases. One covered the upper sediments of the Selinous Alluvium and the second phase the limestones below (Bauer, 2004). Thus the two different phases were evaluated separately. All results are shown in Tab. V.6.

Tab. V.6: Derivation of the hydraulic parameters performed in the Selinous valley.

\begin{tabular}{|c|c|c|c|c|c|c|c|c|c|c|}
\hline solution & $\mathrm{T}[\mathrm{m} 2 / \mathrm{s}]$ & $\mathbf{S}$ & $\beta$ & Sy & $\mathrm{Kr}[\mathrm{m} / \mathrm{s}]$ & $\mathrm{Kz}[\mathrm{m} / \mathrm{s}]$ & $\mathrm{K}[\mathrm{m} / \mathrm{s}]$ & $\mathrm{K}^{\prime}[\mathrm{m} / \mathrm{s}]$ & Ss & Ss' \\
\hline 1) Neumann unconfined & $9.4 \times 10^{-3}$ & 0.02 & 0.8 & 0.58 & $1.8 \times 10^{-4}$ & $2.1 \times 10^{-3}$ & - & - & - & - \\
\hline 3) Neumann Quick & $9.2 \times 10^{-3}$ & 0.02 & 1 & 0.66 & $1.8 \times 10^{-4}$ & $2.66 \times 10^{-3}$ & - & - & - & - \\
\hline 4) Moench, unconfined & $9.01 \times 10^{-3}$ & 0.1 & 1,057 & 0.50 & $1.80 \times 10^{-4}$ & $2.82 \times 10^{-3}$ & - & - & - & - \\
\hline 5) Moench, fractured; slab & $9.01 \times 10^{-3}$ & - & - & - & - & - & $1.57 \times 10^{-4}$ & $3.69 \times 10^{-9}$ & $1.14 \times 10^{-4}$ & $1.69 \times 10^{-2}$ \\
\hline 6) Moench, Kluft-GWL; spherical & $6.90 \times 10^{-3}$ & - & - & - & - & - & $1.37 \times 10^{-4}$ & $1.63 \times 10^{-9}$ & $3.29 \times 10^{-4}$ & $1.53 \times 10^{-2}$ \\
\hline
\end{tabular}

The hydrochemical type of the sampled pump test groundwater (Fig. V.10) and of the surrounding wells in the Selinous is Calcium-Hydrogen-Carbonate with normal earth alkali content (after Furtak \& Langguth, 1967 and Piper, 1944). They all derives from the Olonos-Pindos Platy Limestone Formation. The strong dominance of $\mathrm{Ca}^{2+}$ and $\mathrm{HCO}_{3}{ }^{-}$show limestone origin and is very similar to the analyzed springs in the hinterland in between the Pindos limestones (Klokos area). The slightly higher values in $\mathrm{Ca}^{2+}$ and $\mathrm{HCO}_{3}{ }^{-}$and other Ions are the result of a higher residence and transportation time of the water pumped in contrast to the sampled water on surface nearby springs in the hinterland (Klokos area). It is concluded that the pumped water is not influenced by any marine origin but is from the lower limestone parts. It is recharged in the hinterland south of the well-site which is confirmed by the result of no-flow boundary conditions of the hydraulic test. 

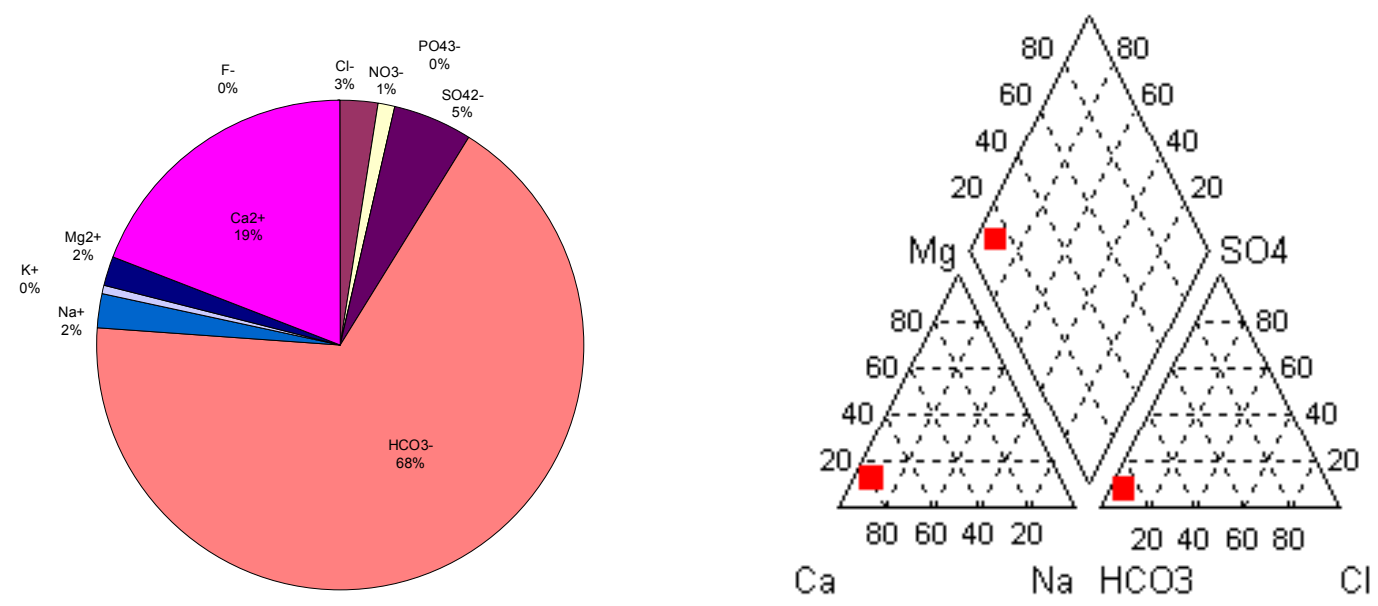

Fig. V.10: Hydrochemical analysis and Piper diagram of the investigated Selinous water samples.

\section{V.2.1.2 Meganitas valley testing}

The hydraulic test in the Meganitas valley (Fig. II.2) provided information about the hydraulic properties of the Alluvium and the flow velocity of the river sediments as well as from the lacustrine lagoonal sediment unit. The pumping well PB3 is $85 \mathrm{~m}$ deep and is in an distance of $34,6 \mathrm{~m}$ from the observation well B3 in the same geological unit. Due to the lack of the recording of the litho-log the lithologic succession is not well known but is evidenced by the $125 \mathrm{~m}$ deep observation well which comprises first river sediments and in 125 very fine material (no cuttings, pers. communication from the owner) which supposed to be from the lacustrine-lagoonal-marine deposits.

Processing of the time-drawdown-recovery data using AQTESOLV ${ }^{\circledR}$ arise that the best fitting is given by the Neumann (1974) solution for unconfined aquifers considering delayed gravity response (halfunconfined). Responsible for the leakages in the sediments could be clay layers or limnic fine sediment bands causing $1^{\text {st }}$ confined conditions before delayed gravity response occur in the $3^{\text {rd }}$ phase. For the complete sequence average conductivities of $10^{-4} \mathrm{~m} / \mathrm{s}$ and estimated transmissivities of $10^{-3}$ were calculated (Tab. V.7). The results of the Meganitas Alluvium hydraulic properties could not be integrated in the numerical model because the quaternary layers are too thin for taken them into account. But for proving and extending the hydrogeological map (Fig. VII.2) however the results were of great value for developing the conceptual hydrogeological model.

Tab. V.7: Derivation of the hydraulic parameters performed in the Meganitas valley

\begin{tabular}{l|c|l|c|c}
\hline Solution & $T\left[\mathrm{~m}^{2} / \mathrm{s}\right]$ & $\mathrm{S}$ & $\begin{array}{c}k_{f, H}[\mathrm{~m} / \mathrm{s}] \text { für } M= \\
25 \mathrm{~m}\end{array}$ & $\begin{array}{c}k_{f, H}[\mathrm{~m} / \mathrm{s}] \text { für } M= \\
82 \mathrm{~m}\end{array}$ \\
\hline Theis, confined & $2,901 \times 10^{-3}$ & $2,285 \times 10^{-3}$ & $1,16 \times 10^{-4}$ & $3,54 \times 10^{-5}$ \\
Hantush, half- confined & $1,128 \times 10^{-3}$ & $9,313 \times 10^{-6}$ & $4,51 \times 10^{-5}$ & $1,38 \times 10^{-5}$ \\
Theis, unconfined & $2,91 \times 10^{-3}$ & $2,294 \times 10^{-3}$ & $1,16 \times 10^{-4}$ & $3,55 \times 10^{-5}$ \\
Neumann, half unconfined & $2,61 \times 10^{-3}$ & $9,31 \times 10^{-4}$ & $1,04 \times 10^{-4}$ & $3,18 \times 10^{-5}$ \\
\hline
\end{tabular}




\section{V.2.1.3 AIG10 hydraulic borehole testing}

AIG10C

Aim of the $1^{\text {st }}$ pumping test AIG10C in the AIG10 borehole was to obtain knowledge about the hydraulic and hydrochemical properties of the Delta conglomerates in the hanging-wall of the Aigion normal fault (Fig. V.11). This $261 \mathrm{~m}$ thick sequence consist mainly of well-rounded limestone, marl and sandstone detritus as well as subangular radiolarite and cherts eroded from the Olonos-Pindos Formation, representing delta environment. Large series of these partly uplifted delta sequences are exposed in a widespread area to the south of Aigion and often block faulted along the coastline of the Gulf of Corinth. For this reason the hydraulic properties are important for the input to the conceptual and numerical model.

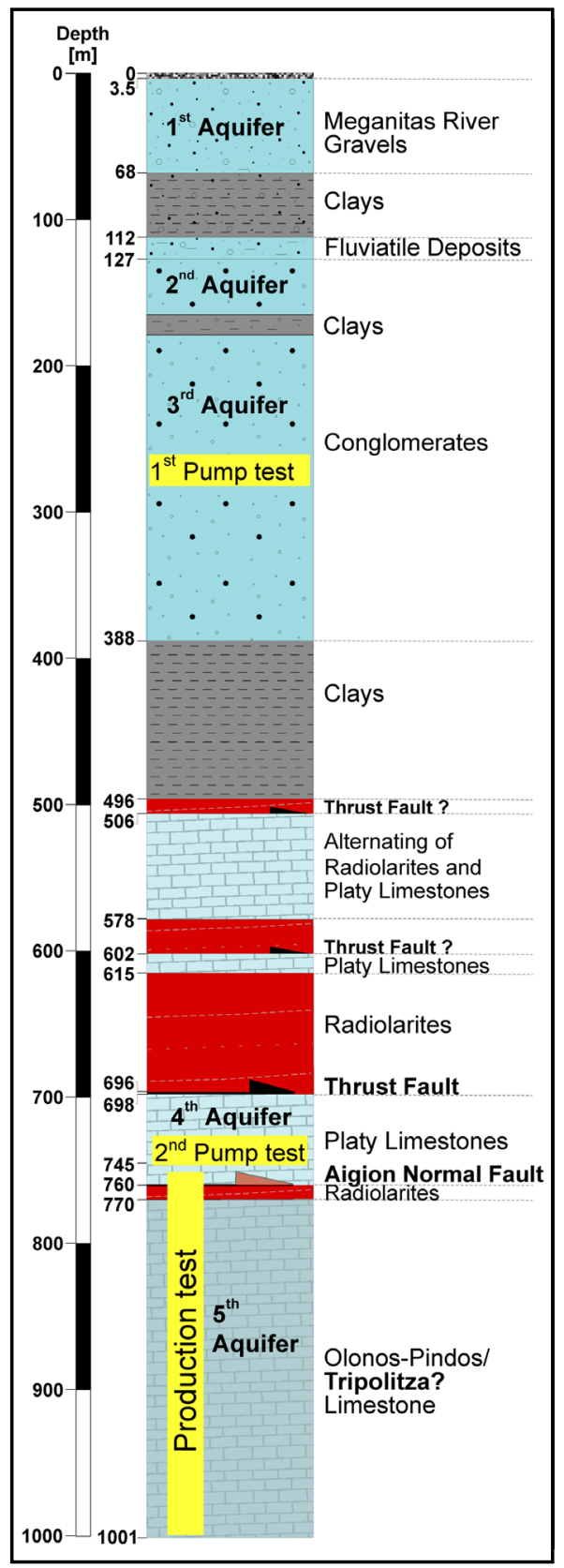

Fig. V.11: Schematic litho-log of the AIG10 borehole with hydrostratigraphy and location of pump tests. 


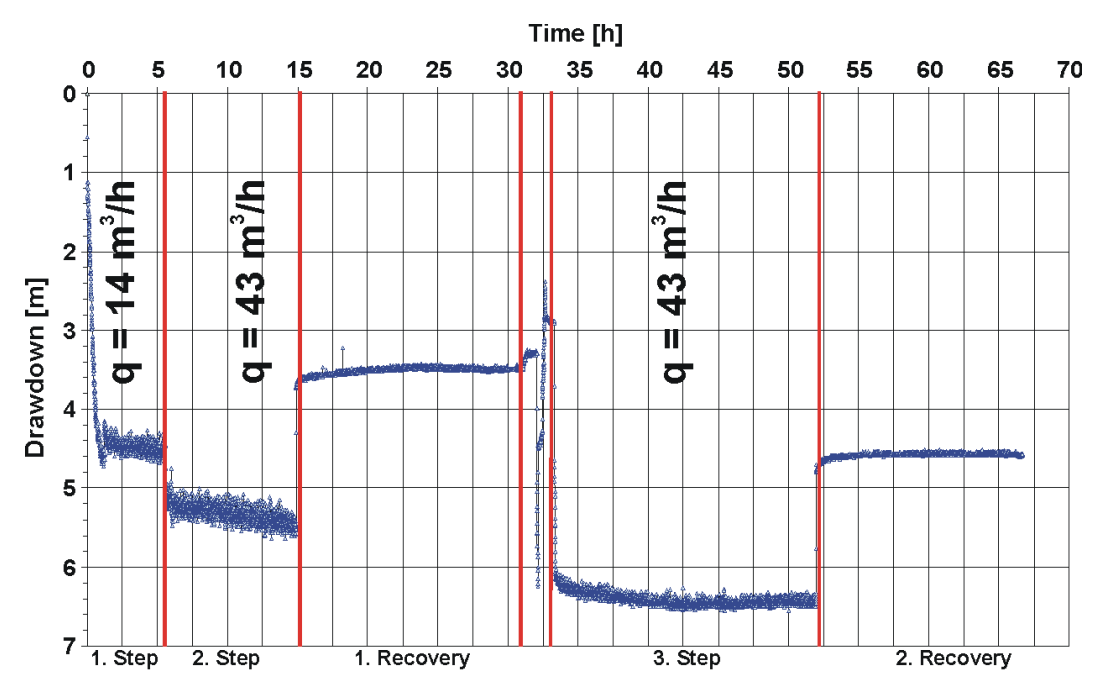

Fig. V.12: Time-dependent drawdown of the $1^{\text {st }}$ pump test AIG10C in the AIG10 borehole with three pumping steps and two recovery phases.

The hydraulic test was made in a 95/8" diameter open-hole interval in the conglomerates between 211 and $256.4 \mathrm{~m}$ (Fig. V.11). A pump was mounted to the production string and set at a depth of $90 \mathrm{~m}$ in the cased borehole interval. The test was planned for a 'three step discharge test', while the pump rate is increased after different time periods (Fig. V.12). The pressure sensor (Eijkelkamp-Sonde) for automatic continuous registration of the drawdown and rise of the water level was attached on the water pipe $10 \mathrm{~m}$ above the pump and light sensors were used simultaneously. The total duration of the step test was 67 hours and the level registration was made every 15 seconds.

From the solutions provided by AQTESOLV ${ }^{\circledR}$ (Tab. V.5) the Moench leakage approach show the best fitting and a hydraulic conductivity of approx. $2.7 \times 10^{-5} \mathrm{~m} / \mathrm{s}$ for the conglomerates (Fig. V.13a). The Moench leakage approach is based on the Hantush theory of leaky confined aquifers (Hantush, 1961a, $1961 \mathrm{~b})$ and is assuming storage in the aquitards or wellbore skin (=the zone of reduced or enhanced permeability around a wellbore) and that an aquitard is overlain by either a constant head boundary or a no-flow boundary (Duffield, 1999). In the $205 \mathrm{~m}$ deep borehole $\Gamma 1$, located $250 \mathrm{~m}$ south of AIG10, no water level changes were registered during the pumping. That leads to the assumption that this is the matter of the presence of a constant head boundary in contrast to a no-flow boundary. 


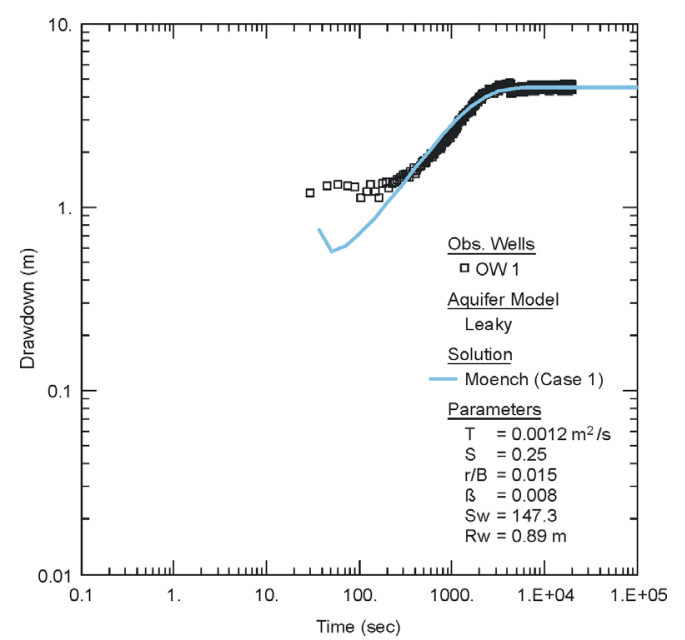

a)

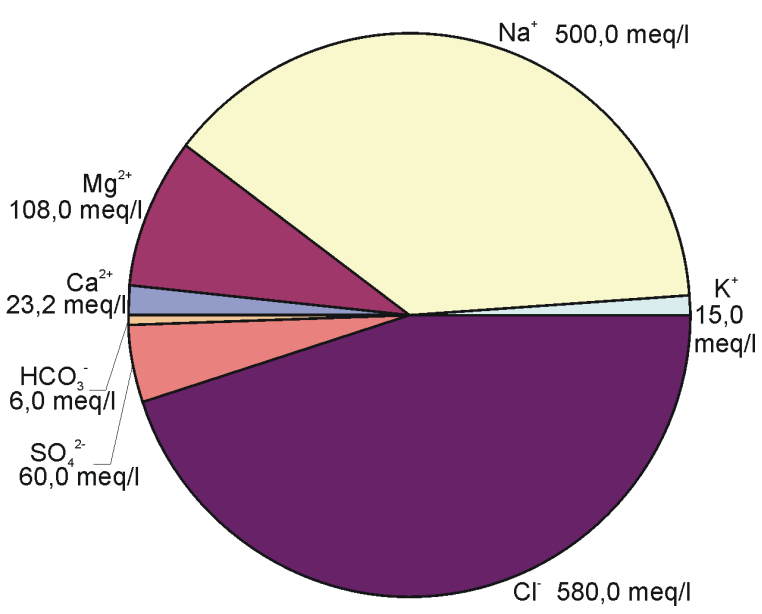

b)

Fig. V.13: a) Processing results of the $1^{\text {st }}$ pump test AIG10C. b) Results of hydrochemical analysis of the sampled water from the $1^{\text {st }}$ pump test AIG10C (in meq/l).

At test beginning the water level was only $1 \mathrm{~m}$ below the top of the installed annular blowout preventer ( $2 \mathrm{~m}$ asl) which means confined and almost artesian conditions. The total residual drawdown of more than $4.5 \mathrm{~m}$ (Fig. V.12) could be explained by a semi-isolated conglomeratic aquifer. The semi-isolation is probable due to the presence of an impervious vertical boundary to the South (Aigion fault plane) and to the clay layers above and beneath the tested conglomerates (Fig. V.11).

It is likely that the Aigion fault represents such a boundary, if the fault acts in this sector as an impermeable barrier to the south. Due to the distant hydraulic contact to the sea, a very slow recovery then would be probable. However, the best curve fitting was obtained by considering leakage through the thin, overlaying clay at 160-m depth or from deeper layers within the conglomerates.

The hydrochemical analyses of the pumped water show a very strong domination of the $\mathrm{Na}^{+}$- and $\mathrm{Cl}^{-}$ ions (Fig. V.13). This result, together with the calculated ion-ratios of the major elements and the minor and trace element contents $(\mathrm{Br}, \mathrm{Sr}, \mathrm{Li}$, etc.), led to the conclusion that the water in the conglomerates is clearly of marine origin, though the total dissolved solids (electric conductivity of 56 $\mu \mathrm{S} / \mathrm{cm}$ ) are higher than seawater. This relatively high value can be explained through drilling mud influence which consist e.g. of Na-Bentonite. However, the $261 \mathrm{~m}$ thick conglomerate sequence in the borehole and litho-log must be well hydraulically isolated from the formations above and beneath it, with a hydraulic semi-permeable barrier in the South and a hydraulic contact with seawater in the Gulf of Corinth in the North.

AIG10L

After cementing the casing down to $708 \mathrm{~m}$ and coring from 708 to $744.8 \mathrm{~m}$, the second pump test AIG10L was performed within the Olonos-Pindos platy limestones (Fig. V.11, $4^{\text {th }}$ aquifer). The $36,8 \mathrm{~m}$ long and $63 / 4$ " wide open hole is located in the hangingwall of the Aigion normal fault approx. $20 \mathrm{~m}$ above the fault plane. The natural water pressure measured at surface was $0.5 \mathrm{MPa}$ and the artesian flow rate was estimated to $1.88 \times 10^{-4} \mathrm{~m}^{3} / \mathrm{s}$. The same equipment as in the first pump test AIG10C was used whereas the pump was installed in $118 \mathrm{~m}$ depth with the pressure sensor for automatic registration (measure range $100 \mathrm{~m}$ ) attached in $107 \mathrm{~m}$ depth. Additionally a measuring system using 
normal pressure gauges and light sensors were installed to extract the measurement range to $>107 \mathrm{~m}$ and for measuring the combination of both, pressure gauge measurement for the artesian pressure and water level measurements with a pressure probe during the experiment. The reference level for the groundwater pressure level is set to the bottom of the annular blowout preventer.

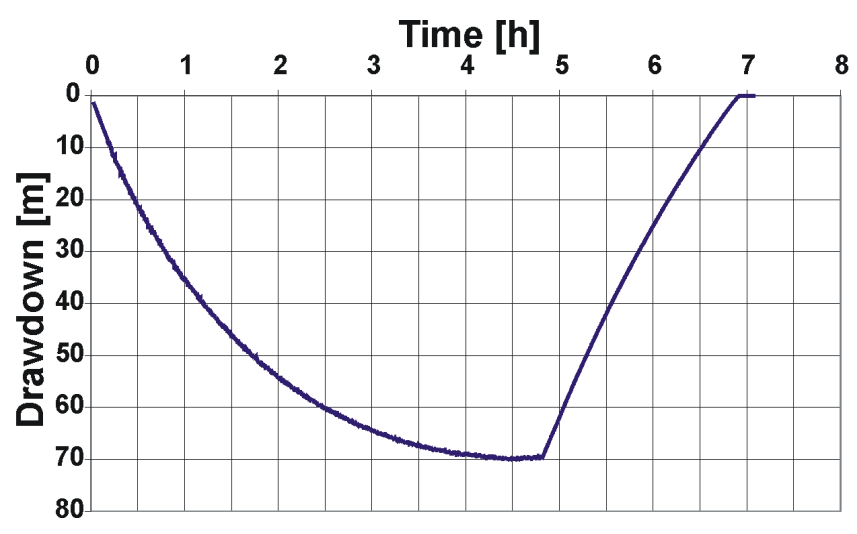

Fig. V.14: Time-dependent drawdown of the $1^{\text {st }}$ pump test AIG10C in the AIG10 borehole with three pumping steps and two recovery phases.

Because of the very poor permeability of the limestones the first pumping trials produces high drawdowns of $>118 \mathrm{~m}$ in short time so that the pump falls dry. It was necessary to close the valve to increase pressure through curbing to reduce the pumping rate. After several trials it was finally possible to perform the test at a flow rate of $3.8 \times 10^{-4} \mathrm{~m}^{3} / \mathrm{s}$. The total duration of the step test was planned to 72 hours but had quasi-stationary conditions after 06:07 hours (Fig. V.14).

Using AQTESOLV ${ }^{\circledR}$ the best results of curve fitting are obtained by the Moench leakage approach and especially by the Moench approach for fractured aquifers (Fig. V.15a). The used geometric parameter required in the Moench's solution for the dimension of the spherical blocks was defined to $20 \mathrm{~cm}(0,2$ $\mathrm{m}$ ) in accordance with field and core investigations. The correlation of the Theis solution (confined) with the Moench solution shows that the Theis-k-values for hydraulic conductivity were in the same range as the k-values for the fractures (not the matrix) determined through the Moench fractured method but the Theis solution didn't fit as good as the Moench fractured variants (Unkel, 2004). Thus it is assumed that the aquifers in the limestones are fractured or even karstic.

For the leakage approach data processing resulted in a hydraulic conductivity $\mathrm{K}$ of $4 \times 10^{-6} \mathrm{~m} / \mathrm{s}$ and a transmissivity $\mathrm{T}$ of $1.47 \times 10^{-4} \mathrm{~m}^{2} / \mathrm{s}$. The results for the fractured aquifer approach is determined to $\mathrm{K}$ $=1 \times 10^{-7} \mathrm{~m} / \mathrm{s}$ for hydraulic conductivity (equivalent transmissivity $\mathrm{T}=3.68 \times 10^{-6} \mathrm{~m}^{2} / \mathrm{s}$ ). For the processing of the "one-hole" pumping test we assumed a fictive observation well located directly aside the pumping well in a few centimeters distance. But for a reliable determination of the specific storage of the fractures (Ss) or the leakage (Ss') and the hydraulic block conductivity $\left(\mathrm{K}^{\prime}\right)$ one needs an observation well in the vicinity of the pumping well with the groundwater level situated in the same aquifer as the pumping well. We had this conditions only at the pumping test site carried out in the limestones of the Selinous valley, where reliable values for the matrix-k and the storativity of the 
Olonos-Pindos Limestones were determined. It is not possible to make any determinations or even approximation for the storativity from a "one hole" - pumping test and from the experience with Aqtesolv the same applies for the hydraulic conductivity K' of the matrix. Thus the Ss-, K'-, Ss'- values shown in Fig. V.15a and the relation between the hydraulic conductivity for the fractures $\mathrm{K}$ and for the block "matrix" $\mathrm{K}$ ' have to be understood as a very raw approximation. It is considered that the value ( $\mathrm{k}$

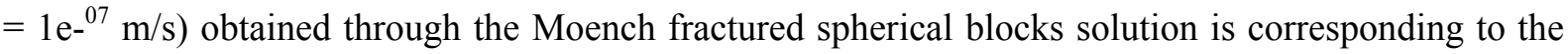
average of the other methods and therefore the most realistic approach based on the "one hole"pumping test.
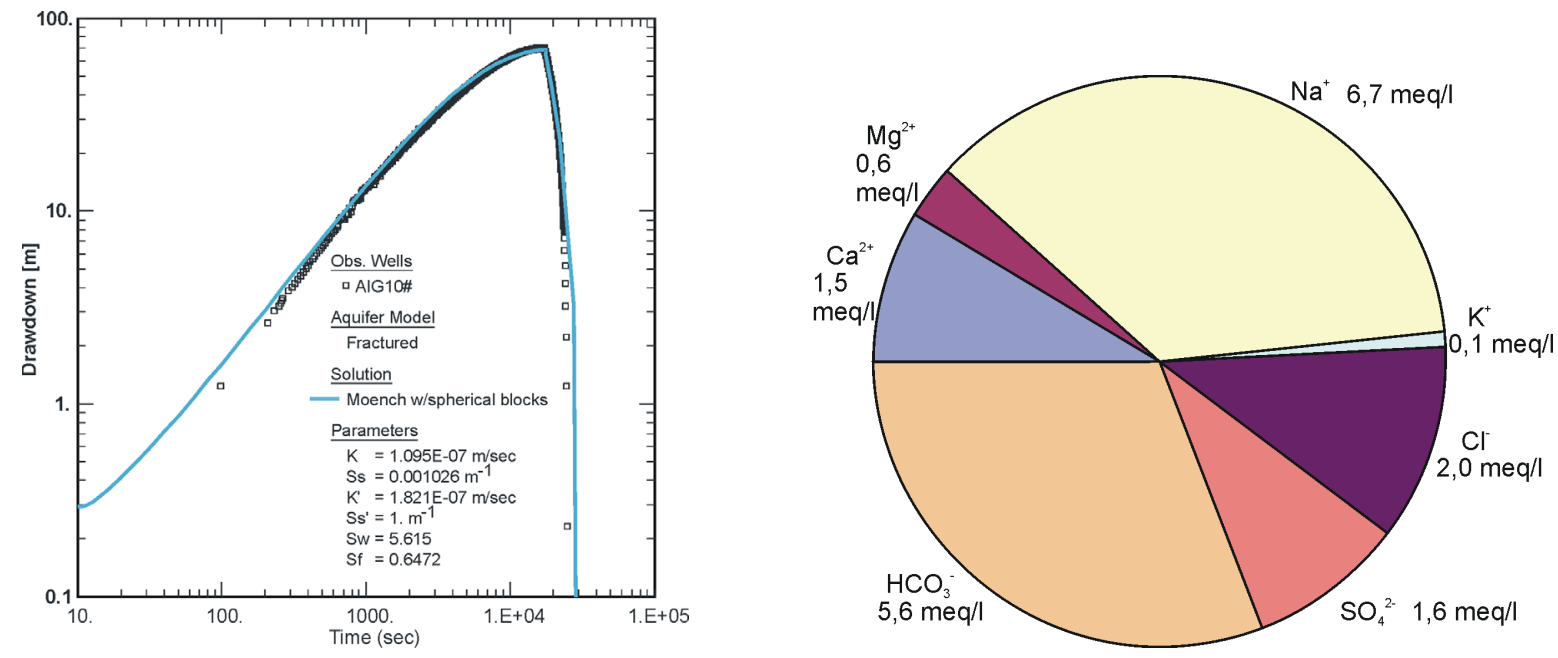

Fig. V.15: a) Processing results of the $2^{\text {nd }}$ pump test AIG10L. b) Results of hydrochemical analysis of the sampled water from the $1^{\text {st }}$ pump test AIG10C (in meq/l).

The hydrochemical analyses of the pumped water show a total mineralisation $<1 \mathrm{~g} / \mathrm{l}$ and is of "drinking-water quality". The results in Fig. V.15b show a strong domination of Na-ions but also a relatively high $\mathrm{HCO}_{3}{ }^{-}$concentration and no significant $\mathrm{Cl}^{-}$concentration to assume marine influence. One the one hand the $\mathrm{Na}^{+}$enrichment could be explained again due to the $\mathrm{Na}^{+}$-Bentonite in the drilling mud. On the other hand it is very likely that reactions with clay minerals occur to justify the $\mathrm{Na}^{+}$ enrichment and the observed $\mathrm{Ca}^{2+}$ and $\mathrm{Mg}^{2+}$ removal from solution (cation exchange). This result, together with the calculated ion ratios and the artesian pressure of $0.5 \mathrm{MPa}$, led to the conclusion that the water in the limestones was recharged in the hinterland of Aigion to the South, where the limestones are outcropping. The tested aquifer is hydraulically well isolated from the aquifers above through aquicludes (110 m marine clay sequence) and the limestones act primarily as an artesian, confined and fractured aquifer. Any hydraulic contact with seawater of the Gulf can be discarded. The physical water parameters measured during the test at the surface in a bucket $(\mathrm{pH}=8.15$; el. conductivity $=780 \mu \mathrm{S} / \mathrm{cm}$ and temperature $=23.5^{\circ} \mathrm{C}$ ) support this theory. 


\section{V.2.1.4 AIG10 production test}

After crossing the Aigion fault by drilling, a sudden increase of pressure and water flux was observed. This observation calls for conditions typical for karstic units, which is supported by the analysis of the drill core obtained at 773-786 m. A three days production test, carried out after drilling covered the depth interval from 708 to $1001 \mathrm{~m}$. Aim of the test was to investigate the hydraulic behavior of flux, pressure changes and temperature if one let the artesian well discharge freely for several days. It is assumed in Chapter V.1.4 that the water below $772 \mathrm{~m}$ depth emanates from the Tripolitza limestones which are known to be characterized by strong karstic conditions. To satisfy this requirement the production test should neither show a strong pressure decrease nor a strong temperature difference or even a temperature increase. Admittedly it is noted that a 3-day-test is too little time or almost insufficient in order to prove whether there is a connection to a well developed karstic system but will give indications for further advisements.

However, the water temperature measured at the surface during the production test varied between 29 $-31^{\circ} \mathrm{C}$ (average $30^{\circ} \mathrm{C}$ ) and is in the range of the bottom hole temperature gained after drilling and from geophysical logging. The artesian pressure before and after the test was constantly $1 \mathrm{MPa}$. Only flux changes a little from $800 \mathrm{l} / \mathrm{m}$ at the beginning to $900 \mathrm{l} / \mathrm{m}$ at the second day. Outwashes of cuttings from the formation in depth could explain this increase. The head losses during the artesian flow reached 0.12 MPa and were calculated according to the Darcy-Weisbach equation (Weisbach, 1845). According to the theory for artesian production tests processing of the data by AQTESOLV ${ }^{\circledR}$ could not be done because during the three days of artesian flow both drawdown ( $1 \mathrm{MPa}-0,12 \mathrm{MPa}=0,88$ $\mathrm{MPa}=88 \mathrm{~m}$ watercolumn) and the natural flow rate of $1.5 \times 10^{-2} \mathrm{~m}^{3} / \mathrm{s}$ remained practically constant. Therefore, the processing is based on the equation of Dupuit-Thiem assuming a constant drawdown at the well radius, equal to $0,88 \mathrm{MPa}$ of artesian pressure and a zero drawdown at a radius of influence $\mathrm{R}$ (Dupuit, 1863, Papadopoulos \& Cooper, 1973, Krusemann \& De Ridder, 1994). Considering for this radius $R$ possible values between 250 and $10^{4} \mathrm{~m}$, an average transmissivity $\mathrm{T}$ of $2.1-3.1 \times 10^{-4} \mathrm{~m}^{2} / \mathrm{s}$ resulted for the $231 \mathrm{~m}$ producing interval $(770-1001 \mathrm{~m}$ depth). These values would correspond to an average hydraulic conductivity of $\mathrm{K}=0.9-1.1 \times 10^{-6} \mathrm{~m} / \mathrm{s}$.

The analysis of the water chemistry (Fig. V.16) shows that the bulk mineralisation is about $1.03 \mathrm{~g} / \mathrm{l}$, so that the water practically is of drinking-water quality except for the $\mathrm{Na}^{+}$-concentration. Similar to the second pump test, we assume that the high Na concentration originates mainly from drill mud and cation exchange processes within clay minerals. The difference in water pressure (pressure step of $>0.5 \mathrm{MPa}$ ) and the difference in the hydraulic properties of the limestones in the hangingwall and in the foot wall of the Aigion fault provides evidence that two compartments exist that communicate hydraulically through the less permeable Aigion fault zone zone with radiolarites in the hangingwall. 


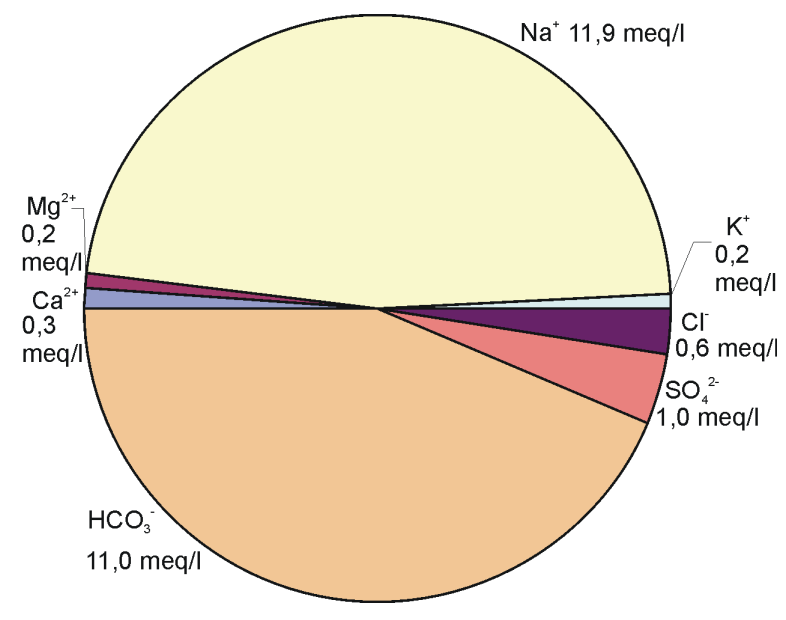

Fig. V.16: Results of hydrochemical analysis of the production test in $\mathrm{mg} / \mathrm{l}$.

It is concluded that the Aigion fault in AIG10 seem to react as a extremely low permeable/semipermeable sequence or even as a hydraulic barrier where platy limestones adjoin to each other in combination to smeared radiolarites. Evidence is given mainly by a pressure gradient of $7.813 \times 10^{-3}$ $\mathrm{MPa} / \mathrm{m}$ in the depth interval of $708 \mathrm{~m}$ (hangingwall; $0,5 \mathrm{MPa}$ ) and $772 \mathrm{~m}$ (foot wall; $1 \mathrm{MPa}$ ) which are one of the most important parameters to calibrate the hydrogeological numerical flow model. The formation water of both, the platy limestones and the Tripolitza limestones possesses no marine influence and is recharged in the hinterland. The hydraulic behaviour of the production test leads to the assumption that from $772 \mathrm{~m}$ the Tripolitza karstic system is encountered in the borehole. 


\section{V.2.2 Groundwater dating}

Additionally to hydraulic testing and hydrochemical analysis, groundwater dating provides very useful information for the hydrogeological model about groundwater age, flow paths, average flow velocity, origin and mean residence time of the groundwater. For this reason investigations on water samples from AIG10 as well as from springs and wells of deep and shallow origin were performed.

One of the most reliable methods for the dating of young groundwater with ages up to 50 years is based on the rare Helium isotope ${ }^{3} \mathrm{He}$ (Aeschbach-Hertig, 1998). It results from $\mathrm{H}_{2} \mathrm{O}$ by radioactive decay of the hydrogen isotope Tritium $\left({ }^{3} \mathrm{H}\right)$, bound in the water molecule. Normally it is available in nature by the cosmic radiation in very small quantities in the atmosphere. But large quantities of Tritium were set free from nuclear reaction due to underground tests of thermonuclear weapons in the 1950 and early 1960 years. The resulting "tritium peak" in the precipitation serves in the following decades as useful time markers in hydrology. The radioactive half-life of tritium is 12.32 years and today Tritium decreased again to almost natural level so that already the presence of Tritium in the groundwater proves a groundwater formation within the last 50 years (Fig. V.17).

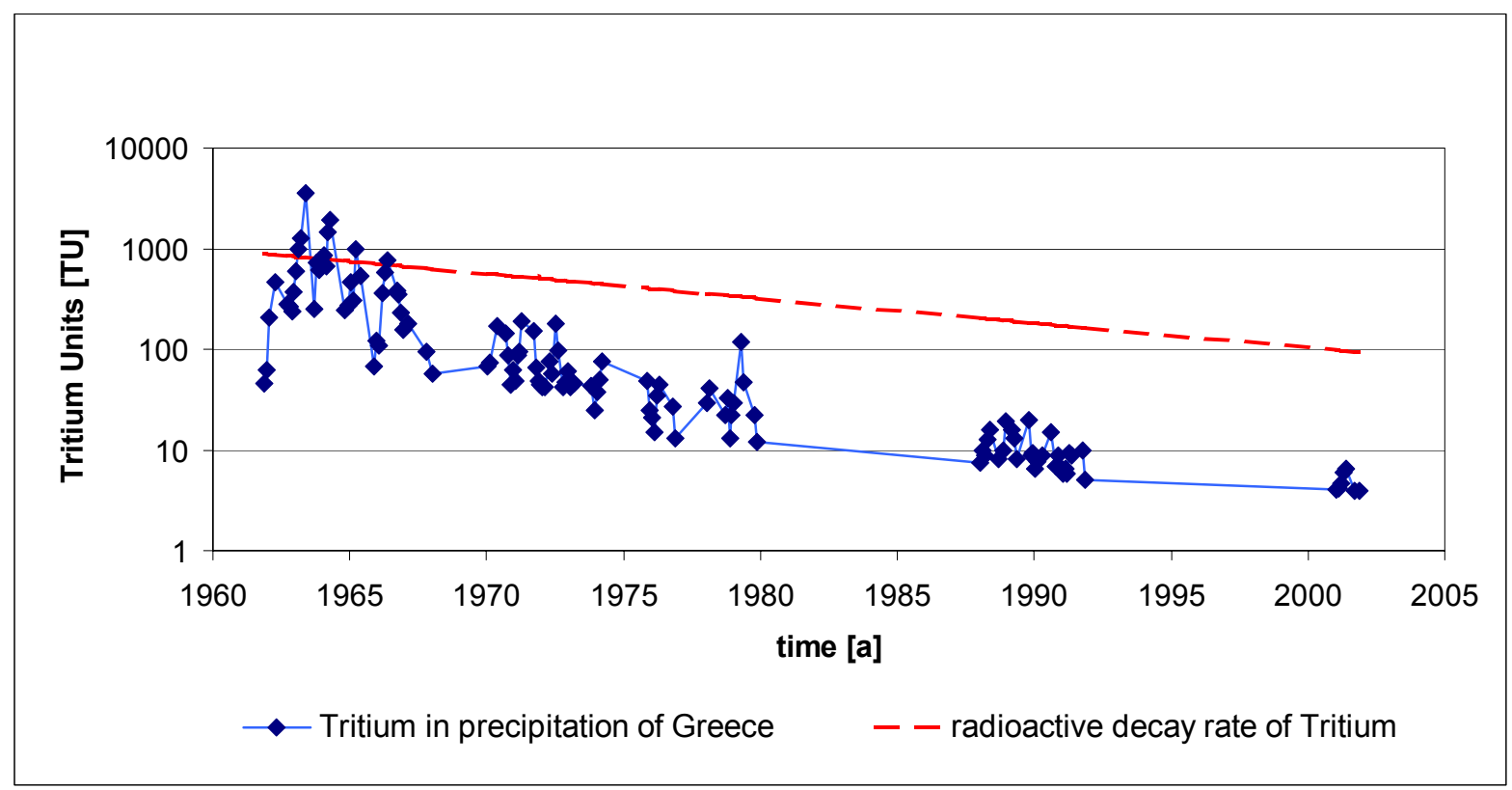

Fig. V.17: Tritium from nuclear bomb tests detected in the precipitation at Athens Airport 1960-1991 and Patra 2000/01 vs. decay rate of ${ }^{3} \mathrm{H}$ Tritium (source: Global Network of Isotopes in Precipitation (GNIP) and Isotope Hydrology Information System (ISOHIS) provided by Prof. Aeschbach-Hertig, Institute of Environmental Physics (IUP), University of Heidelberg). 
The Tritium values of the samples shown in Tab. V.8. ranges from 0.2 TU (Tritium Units) of the Nertazes well (170 m deep; located in the Eliki hangingwall) and 8,8 TU at the Selinous pumping test site EQ2. Most other values are around $5 \mathrm{TU}$. That leads to a problem that it is sometimes difficult to estimate ages alone on Tritium content because here values around $5 \mathrm{TU}$ are well compatible with both the current precipitation and with that of the last approx. 25 years. To solve this problem precipitation Tritium data of Greece have to compare with the measured groundwater sample content. Data of the Aigion region are not available but the sample data are compared to precipitation Tritium data from the Athens airport from 1960-1991 and some data from Patra from 2000-2001 (Fig. V.17). However, these data were sufficient enough to recognize that after the "tritium-peak" of the sixties the values in Greece are dropped from approx. 20 TU (1980) to 10 TU (1990), and 5 TU of today. In Fig. V.17 the decay since 1980 can be barely separated from the natural decay of Tritium with a Radioactive half-life of 12.32 years. This means that the groundwater samples with a value around 5 TU could be either recent precipitation or percolated water from 1980 contaminated with $25 \mathrm{TU}$. Therefore for the input of these data to the hydrogeological conceptual model has to be done with simultaneous consideration of hydraulic test results and regional geology.

Tab. V.8: Content of Tritium in the groundwater samples (in Tritium Units [TU]).

\begin{tabular}{|c|c|c|c|c|c|c|c|}
\hline \multirow{2}{*}{\begin{tabular}{|c|}
$\begin{array}{c}\text { name of } \\
\text { well/spring }\end{array}$ \\
Gamma1 \\
\end{tabular}} & \multirow{2}{*}{$\begin{array}{c}\begin{array}{c}\text { date of } \\
\text { sampling }\end{array} \\
17.06 .2004\end{array}$} & \multicolumn{2}{|c|}{ Tritium (TU) } & \multirow{2}{*}{$\begin{array}{c}\text { name of } \\
\text { well/spring }\end{array}$} & \multirow{2}{*}{$\begin{array}{c}\text { date of } \\
\text { sampling }\end{array}$} & \multicolumn{2}{|c|}{ Tritium (TU) } \\
\hline & & 1,4 & $+/ /-1,1$ & & & & \\
\hline Lions Well & 17.06 .2004 & 4,5 & $+/-1,1$ & B5 & 20.06 .2004 & 4,6 & $+/-1,1$ \\
\hline Neratzes Well & 17.06 .2004 & 0,2 & $+/-1,1$ & R18 & 20.06 .2004 & 5,0 & $+/-0,9$ \\
\hline U34 & 18.06 .2004 & 4,3 & $+/-1,2$ & B12 & 21.06 .2004 & 3,7 & $+/-0,9$ \\
\hline $\mathrm{U} 4$ & 18.06 .2004 & 5,4 & $+/-1,2$ & U12 & 22.06 .2004 & 3,6 & $+/-1,2$ \\
\hline U5 & 18.06 .2004 & 1,9 & $+/-1,3$ & BQ3 & 22.06 .2004 & 4,5 & $+/-1,1$ \\
\hline U18 & 18.06 .2004 & 5,1 & $+/-1,2$ & BQ19 & 22.06 .2004 & 5,8 & $+/-0,9$ \\
\hline U16 & 19.06 .2004 & 5,9 & $+/-1,2$ & EQ2 & 23.06 .2004 & 8,8 & $+/-1$ \\
\hline R6 & 20.06 .2004 & 4,4 & $+/-0,9$ & U33 & 23.06 .2004 & 4,8 & $+/-1$ \\
\hline $\mathrm{R} 8$ & 20.06 .2004 & 7,2 & $+/-1,1$ & $\mathrm{U} 2$ & 23.06 .2004 & 6,5 & $+/-1,3$ \\
\hline $\mathrm{R} 12$ & 20.06 .2004 & 3,9 & $+/-1,2$ & $\mathrm{U} 22$ & 23.06 .2004 & 4,7 & $+/-1,2$ \\
\hline R14 & 20.06 .2004 & 4,8 & $+/-1,2$ & R22 & 23.06 .2004 & 4,9 & $+/-1$ \\
\hline AIG10 & 22.09 .2002 & $-1,04$ & $+/-1,07$ & $\mathrm{U} 40$ & 25.06 .2004 & 1,4 & $+/-1,1$ \\
\hline & $\begin{aligned}<2 & \text { Deep we } \\
\sim 5 & \text { shallow } \\
<1 & \text { Deep we } \\
>7 & \text { Deeper }\end{aligned}$ & $\begin{array}{l}\text { low con } \\
\text { er wells/ } \\
\text { with no s } \\
\text { s; rest of }\end{array}$ & $\begin{array}{l}\text { of tritiun } \\
\text { ings; infilt } \\
\text { ificant } \mathrm{Tr} \\
\text { her peak }\end{array}$ & $\begin{array}{l}\text { mixed water } \\
\text { ted in the last } \\
\text { m } 1960 / 70 \text {; }\end{array}$ & $=>$ older tl & $\begin{array}{l}0 \mathrm{a} \\
0 \mathrm{a} \\
950 \\
0 \mathrm{a}\end{array}$ & \\
\hline
\end{tabular}


Recapitulating one can make the following assumptions. Most of the samples show most likely water which was infiltrated in the last 20-30 a. This refer mainly to the shallow samples and are marked in Tab. V.8 in gray color. The highest value of $8.8 \mathrm{TU}$ is shown at the pumping test site in the Selinous valley (EQ1) where the water emanates from a deep aquifer in-between the platy limestones and is plausible to be of $50-70$ years (rest of the higher peak of the sixties/seventies; red in Tab. V.8). Water sample R8 is a spring at the Fteri village some $20 \mathrm{~km}$ south of the coast and is assumed to be rather younger in contrast to $7.2 \mathrm{TU}$. Very probable however is that the samples with very little tritium $(<<5 \mathrm{TU})$ are clearly older (green in Tab. V.8):

$\begin{array}{lll}\text { - } & \text { T1 } & 1.4 \mathrm{TU} \\ \text { - } & \text { Neratzes Well } & 0.2 \mathrm{TU} \\ \text { - } & \text { U5 } & 1.9 \mathrm{TU} \\ \text { - } & \text { U40 } & 1.4 \mathrm{TU}\end{array}$

At least parts of this samples are from pre-"tritium peak" and are older than 50a. It is concluded that the Neratzes Well samples are classified to be older than 1950 whereas $\Gamma 1$, U5, and U40 could be rather mixed water with younger components. All other samples are characterized to be younger than $\sim 30 \mathrm{a}$. The result from the Sept. 2002 water samples of AIG10 show a Tritium content about zero. The Tritium content in this water is $-1.04+/-1.07 \mathrm{TU}$. That means however that the sample from the deeper parts and from the production test in AIG10 probably contains no significant Tritium and must be older than 50 years.

\section{V.3 Geophysical logging and petrophysical analysis}

\section{V.3.1 Log Interpretation}

Geophysical borehole logging is a measuring method versus depth and time where hydrogeological and petrophysical property data in or around a well are recorded. They provide an objective, repeatable continuous in-situ profile with depth of rock and fluid properties. In AIG10 borehole logging was performed by sensors or sondes lowered down the borehole using a conductor cable on a motorized winch to record the data continuous (Wireline logging). First logs were taken when drilling reached $708 \mathrm{~m}$, a second series was obtained when the borehole reached the final depth of $1001 \mathrm{~m}$. Standard GFZ logging tools were employed to collect data on borehole conditions and on wall-rock petrophysics.

Mud parameters, spectral and total gamma ray (potassium-, uranium-, and thorium), sonic $\log \left(\mathrm{v}_{\mathrm{p}^{-}}, \mathrm{v}_{\mathrm{s}^{-}}\right.$ wave velocity, dt), resistivity $\operatorname{logs}$ (micro-, deep-, induction-logs), one arm caliper $\log$, and temperature logging were measured for the refining of the litho-log and hydrogeological information and for the evaluation of the input-data for modeling (Tab. V.9). Additionally, a temperature profile was measured one year after drilling using the Distributed optical fibre Temperature Sensing technique (DTS) in order to reflect subsurface conditions not affected by drilling and artesian flow. 
Effective use of geophysical data suppose that the analyst interpret the data in the context of known regional geology and hydrogeology. For this the geophysical data strongly supports the litho-log analysis for determining the lithologic stratification derived from cutting and cores using at first graphical treatment of the recorded data (qualitative interpretation). The knowledge of the lithology then permits a continuative view on quantitative interpretations using mathematical methods on the required input data for the conceptual and numerical modeling.

Tab. V.9: Logging activities and derived properties

\begin{tabular}{|c|c|}
\hline logging methods: & determined properties: \\
\hline $\begin{array}{l}\text { Part 1: } \\
\text {-GR total gamma ray (API) before casing } 0-711 \mathrm{~m} \\
\text {-GR2 total gamma ray (API) } 1-1001 \mathrm{~m}\end{array}$ & $\begin{array}{l}\text { - refining cutting and core analysis } \\
\text { - location of stratigraphic boundaries } \\
\text { - defining and correction of depth affiliation } \\
\text { - indication of clay and sediment layers vs. sst-, } \\
\text { limestone- or radiolarite formations } \\
\text { - reference log for other logs }\end{array}$ \\
\hline $\begin{array}{l}\text { Part 2: } \\
\text { - mud parameter } \\
\text { - mud temperature and mud pressure } \\
\text { - electric conductivity } \\
\text { - one-arm caliper log }\end{array}$ & $\begin{array}{l}\text { - support of online cutting analysis and cores } \\
\text { - evidence of hydraulic behavior } \\
\text { - location of aquifers } \\
\text { - indication of open fissures and cavities } \\
\text { - borehole breakouts }\end{array}$ \\
\hline $\begin{array}{l}\text { Part 3: } \\
\text {-resistivity logs (micro-, deep, induction) }\end{array}$ & $\begin{array}{l}\text { - support of litho-log analysis } \\
\text { - evidence of formation water } \\
\text { - porosity estimation (Archie equation) }\end{array}$ \\
\hline $\begin{array}{l}\text { Part 4: } \\
\text { spectral gamma ray Th, U, K }\end{array}$ & \begin{tabular}{|l|} 
- estimation of clay content in the litho-log \\
- cgr to avoid perturbations of organics (U)
\end{tabular} \\
\hline $\begin{array}{l}\text { Part 5: } \\
\text { sonic velocity Vp (p-wave) } \\
\text { delta time dT }\end{array}$ & $\begin{array}{l}\text { - support of litho-log analysis } \\
\text { - location of aquifers } \\
\text { - indication of open fissures and cavities } \\
\text { - porosity estimation (Wyllie equation) }\end{array}$ \\
\hline $\begin{array}{l}\text { Part 6: } \\
\text { temperature logging (DTS) }\end{array}$ & $\begin{array}{l}\text { - AIG10 temperature profile } \\
\text { - calculation of thermal gradient } \\
\text { - calculation of heat flow }\end{array}$ \\
\hline
\end{tabular}

\section{Gamma ray $\log$}

The gamma ray log was used to locate stratigraphic boundaries and to define and correct the depth affiliation of cuttings and cores. The natural emission of gamma rays by a formation was measured in API units (American Petroleum Institute $=$ standardized testing procedures for drilling equipment). The log of the total natural radioactivity in AIG10 is performed in both, open hole and cased hole. The depth of penetration into the formation are several centimeters, so that the log normally measures the adjoining borehole zone.

Clay minerals are most responsible for natural radioactivity in a stratigraphic sequence, so the gamma ray $\log$ often is a good indicator for sediments of clayey nature. Typical sandstones, limestones, 
dolomites and radiolarite have relative low concentration of radioactive isotopes unless they contain disseminated shales, feldspar or mica.

Most important source of radiation is the concentration of thorium (Th) fixed to the clay minerals by absorption and cation exchange (Doveton, 1994a). Additionally small amounts of uranium (U) are present in clay minerals but can be high concentrated by e.g. organic matter. $0.02 \%$ of the radioactive isotope $\mathrm{K}-40$ is from potassium $(\mathrm{K})$ which represents the smallest amount of radiation in clays. In a logging campaign the number of decay measured are the sum of all gamma rays (total gamma ray or spectral gamma ray (SGR) (Fig. V.18). To avoid perturbations by uranium due to organic material the SGR is splitted and the uranium is subtracted from Th and K (Fig. V.19). The result is the computed gamma ray (CGR) and now the summation of thorium and potassium sources gives good estimations for clay content.

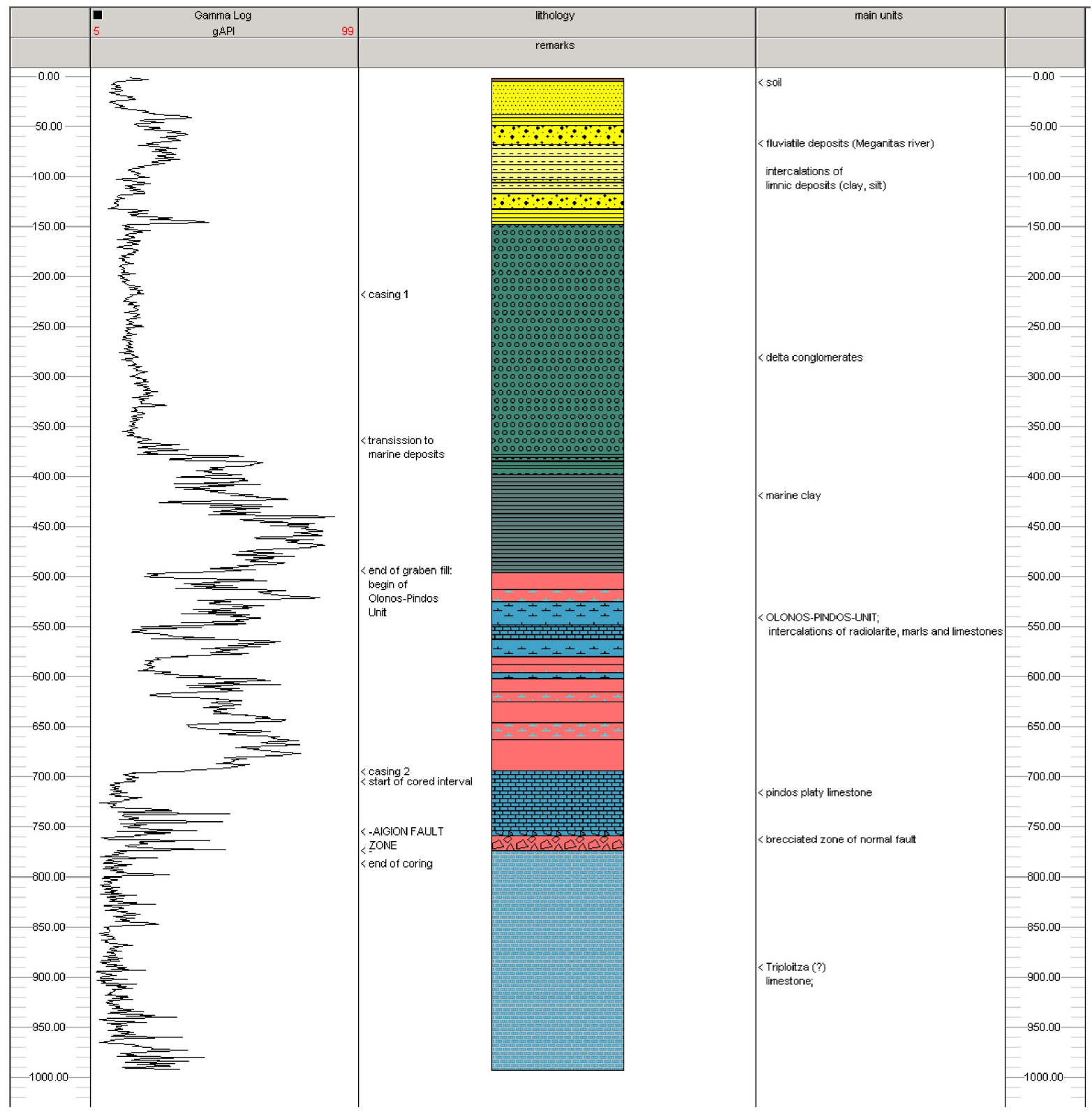

Fig. V.18: Interpretation of the spectral gamma ray log (SGR). (Legend see Appendix) 
Curve-variations can be seen above $150 \mathrm{~m}$ (Fig. V.19). The SGR traces clearly the river sediments, limnic intercalations and clay layers before the delta conglomerates are encountered in $149 \mathrm{~m}$ depth. Here the beginning of the Gilbert-type delta conglomerates are corrected to this depth according to the cutting analysis where they assumed to start at $127 \mathrm{~m}$. But it is also possible from the logs, that the peak at 146-149 $\mathrm{m}$ is due to a clayey intercalation in between the delta conglomerates. The decrease of the curve at $127 \mathrm{~m}$ from 28 to 12 API would be coherent.

Fig. V.19 show that the SGR-log is very uniform from $150 \mathrm{~m}$ down to $382 \mathrm{~m}$ with around 20API corresponding with the delta conglomerates. As the conglomerates are a mixture of limestones, flysch and radiolarite without high clay content and more carbonate to siliceous matrix this is to understand as a average value. Very clear is the transition from the conglomerates to the marine clay beginning at 381 to $388 \mathrm{~m}$ which is conform with the cutting analysis. Strong variations are shown down to $690 \mathrm{~m}$ depth. This sequence is very heterogeneous, shown by all geophysical logs and by the cutting analysis as well. In the analysis of this sequence, the gamma log was the most useful tool to verify the cutting analysis. The sequence is enlarged and analyzed in Fig. V.3. Based on the SGR and p-wave velocity, the lithology was refined to radiolarite with more or less clayey contents, limestones, marls or marly carbonates as well as clay contents in flysch sandstones. It is noted here that this very detailed stratification could not be transferred into the numerical model and had to be generalized. For the model the stratigraphy of the sequence from $496 \mathrm{~m}$ down to $698 \mathrm{~m}$ is divided into general sections according to thermal conductivity and heat temperature gradient (see Chapter VII).

The transition between the older Radiolarite Formation and the younger Platy Limestone Formation then is well established at $698 \mathrm{~m}$ (60 API down to $15 \mathrm{API}$ ). The thrust fault, however, is not marked in the gamma log.

Cores from 708.08 to $787.40 \mathrm{~m}$ depth show marly intercalations and marlstones from $730 \mathrm{~m}$ which can be well recognized by the log. Also the cataclastic bands where fault cataclastic material and hydrothermal calcite healings are prevailing (Fig. V.6) can be related to higher peaks in the log.

After crossing the Aigion normal fault, the strong curve variations reduce again and a relatively conform gamma ray below 30 API dominates. Platy limestones and the assumed dolomitic Tripolitza limestones below $772 \mathrm{~m}$ cannot be distinguished by the gamma log. Both, carbonates and dolomitic carbonates in AIG10 show low levels of radioactivity $<30$ API. Some peaks below $800 \mathrm{~m}$ could be related to cavities in the karstic succession below the fault, but here sonic logs gives more evidence. 


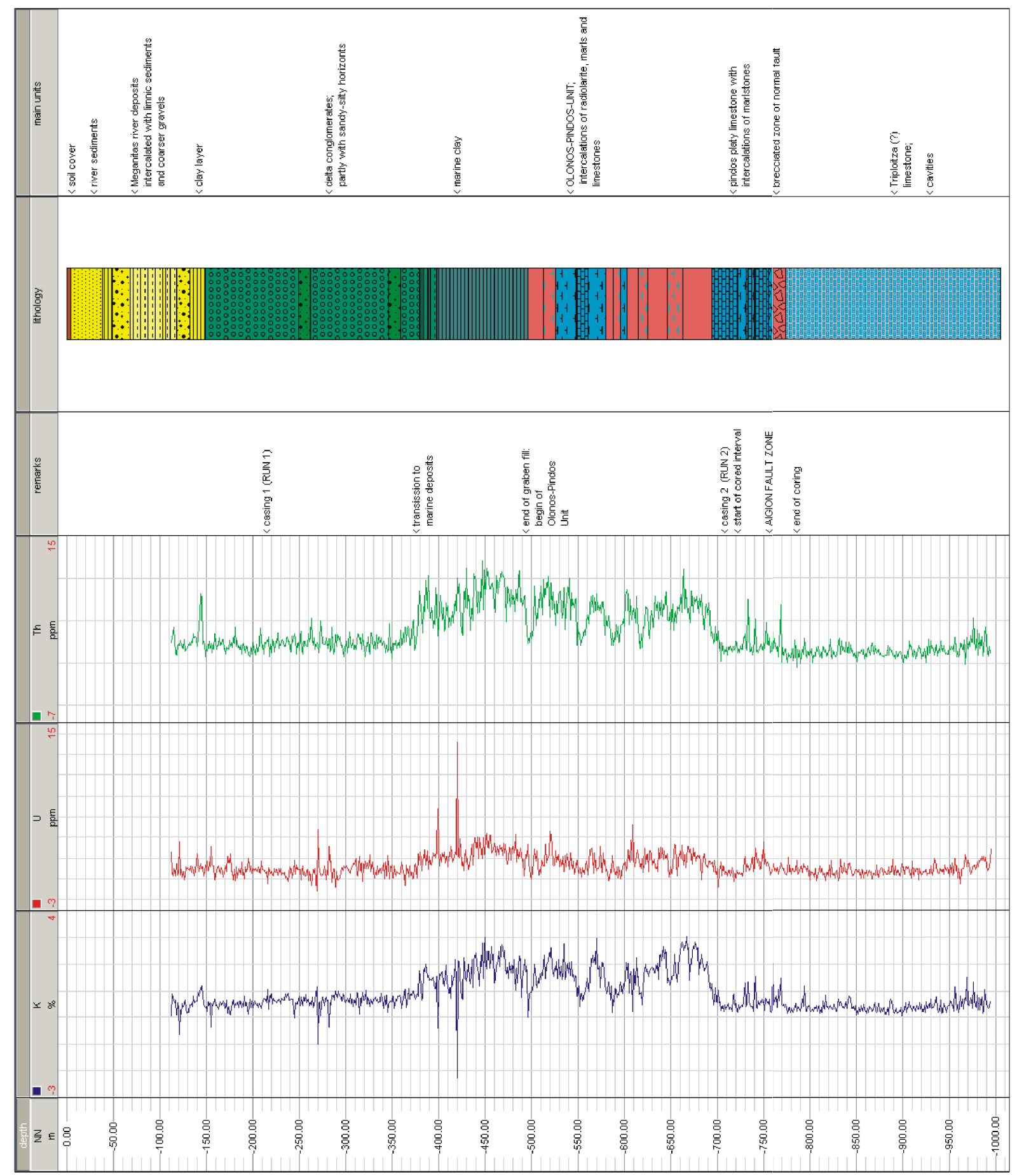

Fig. V.19: Spectral gamma ray log (SGR) into the components Uranium (U), Potassium (K), and Thorium (Th) with lithological interpretation. (Legend see Appendix) 
Sonic acoustic velocity log

A sonic log is a type of acoustic log which displays the travel times of ultrasonic waves versus depth and can only recorded in open holes (not in casings). A transmitter emits a sound wave that travels from the source through the geological formation back to a receiver. The standard logging tool used in AIG10 by GFZ is equipped with 2 transmitters and 2 receivers in order to correct errors introduced by tilting of the tool within a borehole and to give higher resolution to the measurement. The characteristics of the sonic log tool used is listed in Tab. V.10. The measurements in a sonic log are not a point value but an average within a fixed span (according to the tool characteristics 2-3 feet). The velocity " $v$ " then is a property of a medium distance divided by the travel time and describes the rate at which a wave travels through a formation. 4 single travel times were calculated by "first arrival pickup" from the data obtained in AIG10 (Tab. V.11) (BLM - Society for borehole measurements, Gommern, Germany). Using the single travel times, one is able to calculate the differential travel times Deltatime 1 and Deltatime 2 whereas slowness-p (s) is the reciprocal value of the $p$ (s)-wavevelocity $\mathrm{v}_{\mathrm{p}(\mathrm{s})}$.

The signal of the first arrival compressional wave triggers the recording of the transit time. This first arrival describes the primary wave $v_{p}$ whose velocity is dependent on density and elastic rheology of the rock formation. p-waves are longitudinal waves where oscillation occurs in the same direction as the wave propagation. The restoring force for p-waves is provided by the bulk modulus (change in volume of a solid substance by change of pressure related to density). p-waves therefore are especially suited to define units in the AIG10 litho-log with different densities (chert, limestones, clay and intercalations). Transit times through mediums for analyzing the sonic log are given in Tab. V.11 and are based on experienced values of Schlumberger, 1991 and Doveton, 1994a. p-waves are able to travel through fluids but lose on speed if water, aquifers or cavities occur in the geological succession. For the influence of fluids on the sonic $\log$ secondary arrival waves $\mathrm{v}_{\mathrm{s}}$ are useful (resp. reciprocal slowness-s). An s-wave is a wave in an elastic medium in which the restoring force is provided by the shear modulus and is not able to travel through fluids.

Tab. V.10: Compilation of sonic log tool characteristics.

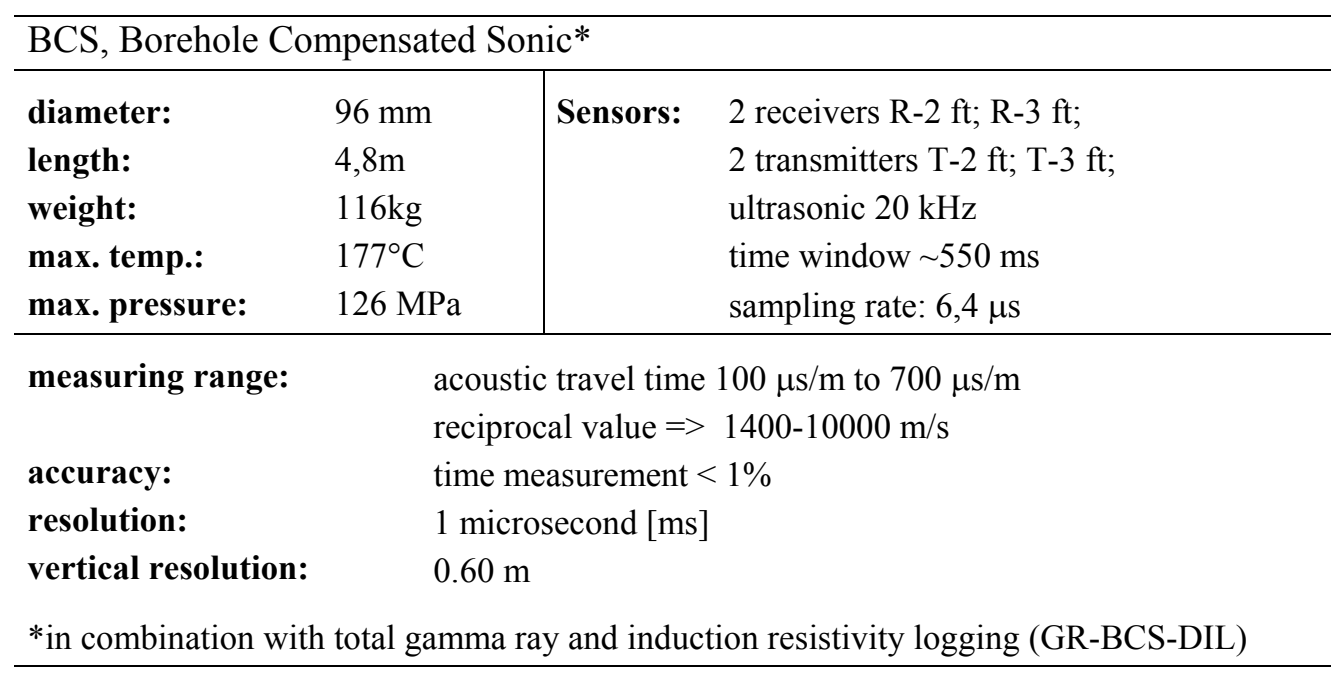


Tab. V.11: Compilation of sonic log measuring characteristics.

\begin{tabular}{|c|c|c|c|}
\hline $\begin{array}{l}\text { obtained single } \\
\text { travel times: }\end{array}$ & $\begin{array}{l}\mathrm{t}-11=\mathrm{T} 1- \\
\mathrm{t}-12=\mathrm{T} 1- \\
\mathrm{t}-21=\mathrm{T} 2- \\
\mathrm{t}-22=\mathrm{T} 2-\end{array}$ & $\begin{array}{l}(3 \mathrm{ft} .) \\
(5 \mathrm{ft} .) \\
(3 \mathrm{ft} .) \\
(5 \mathrm{ft} .)\end{array}$ & $([\mathrm{t}-12]-[\mathrm{t}-11])$ Deltatime1 \\
\hline $\begin{array}{l}\text { Examples for transit } \\
\text { times through medium: } \\
\text { in }[\mu \mathrm{sec} / \mathrm{ft}] \\
\text { (from Doveton, } 1994 \mathrm{~b} \text { and } \\
\text { Schlumberger, 1991) }\end{array}$ & $\begin{array}{l}\text { Quartz } \\
\text { Calcite } \\
\text { Dolomite } \\
\text { Gypsum } \\
\text { Micas } \\
\text { Brine } \\
\text { Oil } \\
\text { Gas }\end{array}$ & $\begin{array}{l}55.5 \\
47.5 \\
43.5 \\
52.0 \\
\sim 50 \\
189 \\
238 \\
626\end{array}$ & $\begin{array}{l}\sim 182 \mu \mathrm{sec} / \mathrm{m} \\
\sim 156 \mu \mathrm{sec} / \mathrm{m} \\
\sim 143 \mu \mathrm{sec} / \mathrm{m} \\
\sim 170 \mu \mathrm{sec} / \mathrm{m} \\
\sim 164 \mu \mathrm{sec} / \mathrm{m} \\
\sim 619 \mu \mathrm{sec} / \mathrm{m} \\
\sim 780 \mu \mathrm{sec} / \mathrm{m} \\
\sim 2051 \mu \mathrm{sec} / \mathrm{m}\end{array}$ \\
\hline $\begin{array}{l}\text { lithological } \\
\text { bandwidth: } \\
\text { (Schlumberger, 1991) } \\
\text { p-wave velocity Vp [m/s] } \\
\text { (Militzer et al., 1986) }\end{array}$ & $\begin{array}{l}\text { sandstones } \\
\text { limestones } \\
\text { dolomites } \\
\text { dolomites } \\
\text { limestones } \\
\text { sandstones } \\
\text { sand } \\
\text { clay }\end{array}$ & $\begin{array}{r}55.5-51.3 \\
47.6-43.5 \\
43.5-38.5 \\
\\
\sim 900-63 \\
\sim 1000-55 \\
\sim 800-45 \\
\sim 300-15 \\
\sim 300-30\end{array}$ & $\begin{array}{l}\sim 182-168 \mu \mathrm{sec} / \mathrm{m} \\
\sim 156-143 \mu \mathrm{sec} / \mathrm{m} \\
\sim 143-126 \mu \mathrm{sec} / \mathrm{m} \\
\mathrm{m} / \mathrm{s} \\
\mathrm{m} / \mathrm{s} \\
\mathrm{m} / \mathrm{s} \\
\mathrm{m} / \mathrm{s} \\
\mathrm{m} / \mathrm{s}\end{array}$ \\
\hline
\end{tabular}

The interpretation of the sonic logs (Delta1, Delta2, $\mathrm{p}(\mathrm{s})$-wave, slowness-p(s)) are displayed from $211 \mathrm{~m}$ (below casing) in the Fig. V.20. At a first glance one can clearly recognize distinctive log responses caused by the rock properties of the main units. The slowness-p-values of the Delta conglomerates ranges between 300-400 $\mu \mathrm{s} / \mathrm{m}$ and are relatively conform except where sandy-silty intercalations are encountered. Marine clays then are indicated by high value response $(398-498 \mathrm{~m})$ equivalent to a low velocity. The s-wave characteristic gives evidence of a higher water content of the marine clay and the p-wave reduces speed as well.

The Olonos-Pindos Formation below the graben sediments is clearly defined in nearly all well-logs and is defined for the conceptual and numerical model at $498 \mathrm{~m}$. The delayed response of the sonic $\log$ compared to the gamma-log in $496-498 \mathrm{~m}$ is probably caused by disaggregation at the transgressional contact and resulting water storage. The radiolarite contact is then followed by a very inhomogeneous sequence from $500 \mathrm{~m}$ to $700 \mathrm{~m}$. A closer inspection shows higher velocities were radiolarite is dominating (e.g. 560-570 m; 602-610 m) and lower velocities where radiolarite is accompanied with clay, marl, marlstones or limestones. For the very complex sequence (498 - 690 m) the sonic log (in combination with other $\operatorname{logs}$, gradient $\log$ and borehole cuttings) was essential to interpret the lithology. 
A very detailed analysis of this sequence is given in Fig. V.3 by comparing the slowness-p-wavevelocity with total gamma ray and temperature gradient log. For a better graphical demonstration peaks over $300 \mu \mathrm{sec} / \mathrm{m}$ are dyed in gray. Limestone intercalations increase the p-wave from $505.5 \mathrm{~m}$ down to $513 \mathrm{~m}$ and decrease again where flysch clayey sandstone is encountered ( $513-524 \mathrm{~m} \mathrm{bsl})$. It is important to remember that slowness-p is the reciprocal value of p-wave-velocity Vp showing therefore opposite peak direction. The prevailing limestones in sequence $524-579 \mathrm{~m}$ show some intercalations. Peaks and associated cuttings show radiolarite intercalations (535 - $542 \mathrm{~m})$, marly limestone $(542-545 \mathrm{~m})$, platy limestones and marl intercalations $(545-\sim 573 \mathrm{~m})$, clayey radiolarite $(573-602 \mathrm{~m})$ and a radiolarite sequence $(602-698 \mathrm{~m})$ with marly siliceous clay, claystone, marly, and limestone intercalations.

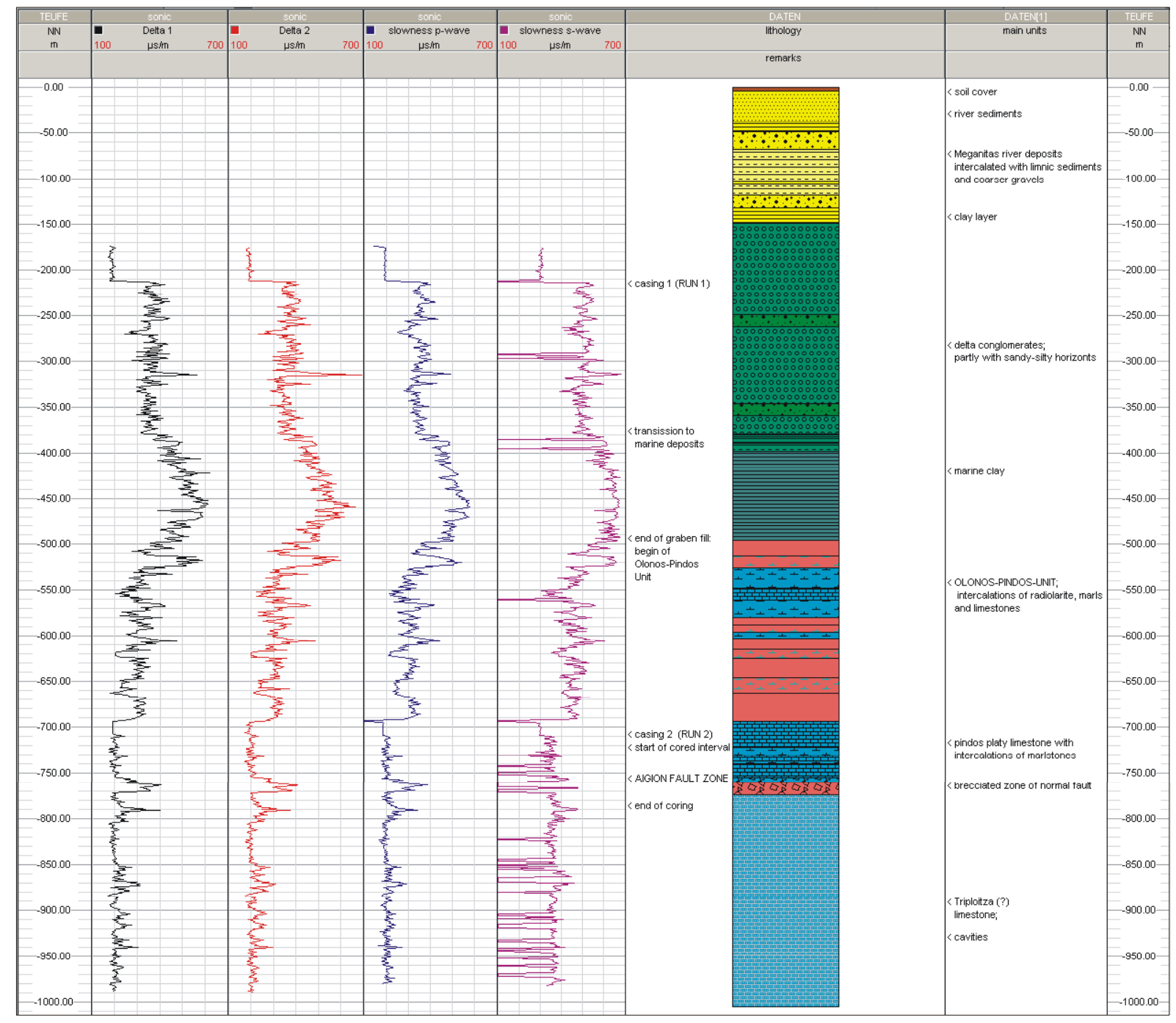

Fig. V.20: Lithological interpretation of the travel times Deltatime 1 and Deltatime 2 and the reciprocal value of p-wave-velocity $1 / \mathrm{v}_{\mathrm{p}}$ (slowness-p) resp. $1 / \mathrm{v}_{\mathrm{s}}$ (slowness-s). (Legend see Appendix) 
The strong decrease of all velocity plots at $\sim 698 \mathrm{~m}$, where solid radiolarite is overlain by platy limestones confirms not only the lithologic change but also the results from the $2^{\text {nd }}$ pumping test indicating fractured aquifer properties. The Aigion normal fault then is imaged by a slow increase from $750 \mathrm{~m}$ and high peaks from $760 \mathrm{~m}$ where the radiolarite (high density, low water content) is encountered in the succession (Fig. V.20). Unfortunately the s-waves are of very low quality that from this $\log$ an evaluation of the fluid influence in between the fault plane could not be done. The amplitudes of $\mathrm{v}_{\mathrm{p}}$ clearly mimic the fault plane much better than the $\mathrm{v}_{\mathrm{s}^{-}}$or the gamma-log.

The following radiolarite breccia (high porosity, lower density) from $762 \mathrm{~m}$ produces strong core losses. The transition to the limestones however is pronounced in $772 \mathrm{~m}$ with an clear increase of the p-wave-velocity from $\sim 3000$ to $5400 \mathrm{~m} / \mathrm{s}$ (Fig. V.20). The lower part down to the total depth of $1001 \mathrm{~m}$ is characterized by less variable amplitudes. p-wave velocity is in the range of $4500->6000 \mathrm{~m} / \mathrm{s}$. Cuttings and the relatively high velocity point to dolomite which represents the underlying tectonic nappe of the Tripolitza Unit. Decreasing p-wave and s-wave velocities (together with other log characteristics on gamma- and resistivity logs) are indicator of cavities or possible karst features such as focused water pass ways possible at $788 \mathrm{~m}, 852 \mathrm{~m}, 866-872 \mathrm{~m}, 900-905 \mathrm{~m}, 927-930 \mathrm{~m}$, or 938$940 \mathrm{~m}$. At this intervals velocity is reducing of about $>50 \%$ pointing to water influence. Considering the known typical karst features of the Tripolitza limestones, the borehole fluid behavior and pressure increase below $772 \mathrm{~m}$, the logging response of resistivity-, gamma-, and sonic log, the lithology below $772 \mathrm{~m}$ is typical for dolomites of the Tripolitza unit. 


\section{V.3.2 Porosity from well logs}

There are three types of geophysical logging tools that are used to estimate the amount of pore space in a rock: the neutron, density, and acoustic velocity tool (sonic) (Doveton, 1994b). Neutron- and density-logs were not performed in AIG10, thus only the sonic logs are available for porosity determination.

Sonic $\operatorname{logs}$ are often referred to as "porosity logs" because the ability of acoustic waves to travel through a rock or sediment is depending on the physical structure of the rock. A transmitted sound wave is a function of a combination of matrix and rock densities, cementation, fracturing and development of joint systems, matrix porosity, and interconnections (amplitude) (Doveton, 2002). Hence well $\log$ porosities generate a relatively good estimate of the whole formation porosity, respectively average porosity (and not of the matrix porosity). By contrast laboratory derived porosities of geological specimen represent matrix porosities. Because laboratory derived porosities differ from well log derived porosities, porosity-dependent parameters (such as thermal conductivity) have to be corrected and adjusted to the well log porosity, respectively formation porosity.

Although geophysicists usually think in terms of velocity, the sonic log is conventionally recorded as transit time in units of microseconds per foot $[\mu \mathrm{s} / \mathrm{ft}]$. Transit times of common matrix minerals are displayed in Tab. V.11. By interpolating between the appropriate matrix value and the transit time for water, the porosity of a lithological sequence may be estimated by the Wyllie time-average equation (Doveton 1994). Wyllie has shown as a result of laboratory investigations on shale free lithology an approximately linear relationship between transit time and porosity:

$\Delta t=\Phi \cdot \Delta t_{f}+(1-\Phi) \cdot \Delta t_{m a}$

where $\Delta t \quad=$ transit time of the investigated zone

$\Delta t_{f} \quad=$ transit time of fluid

$\Delta t_{m a}=$ transit time matrix

$\Phi \quad=$ porosity

transit time in units of microseconds per foot $[\mu \mathrm{s} / \mathrm{ft}]$

1 foot $=3.281 \mathrm{~m}$

Rearranging the formula gives the "Wyllie time average equation" and is then expressed in:

$$
\Phi=\frac{\Delta t-\Delta t_{m a}}{\Delta t_{f}-\Delta t_{m a}}
$$


The transit time $\Delta t_{f}$ used for water is $189 \mu \mathrm{s} / \mathrm{ft}$ and is a useable estimate for the mud filtrate within the formation traversed by the acoustic waves (Doveton, 1994a). The transit time for the matrix $\Delta t_{m a}$ is averaged from the mineral composition of core and surface samples which each represent the appropriate lithological sequence (e.g. quartz $55.5 \mu \mathrm{s} / \mathrm{ft}$, calcite $47.5 \mu \mathrm{s} / \mathrm{ft}$, dolomite $43.5 \mu \mathrm{s} / \mathrm{ft}$ ).

In the case of platy limestones, the transit time is that of calcite $(47.5 \mu \mathrm{s} / \mathrm{ft})$ and for the Tripolitza limestones values for dolomite are used $(43.5 \mu \mathrm{s} / \mathrm{ft})$. For the conglomerate sequence $(0-388 \mathrm{~m}$ bsl in AIG10) the transit time is averaged according to the composition of quartz and calcite to $50 \mu \mathrm{s} / \mathrm{ft}$ whereas for prevailing radiolarite sequences the transit time is that of quartz $(55.5 \mu \mathrm{s} / \mathrm{ft})$. Due to the shale-free precondition the porosity of the marine to lagoonal marls and clays (388 - $496 \mathrm{~m}$ in AIG10) could not be determined with the Wyllie method and is approximated.

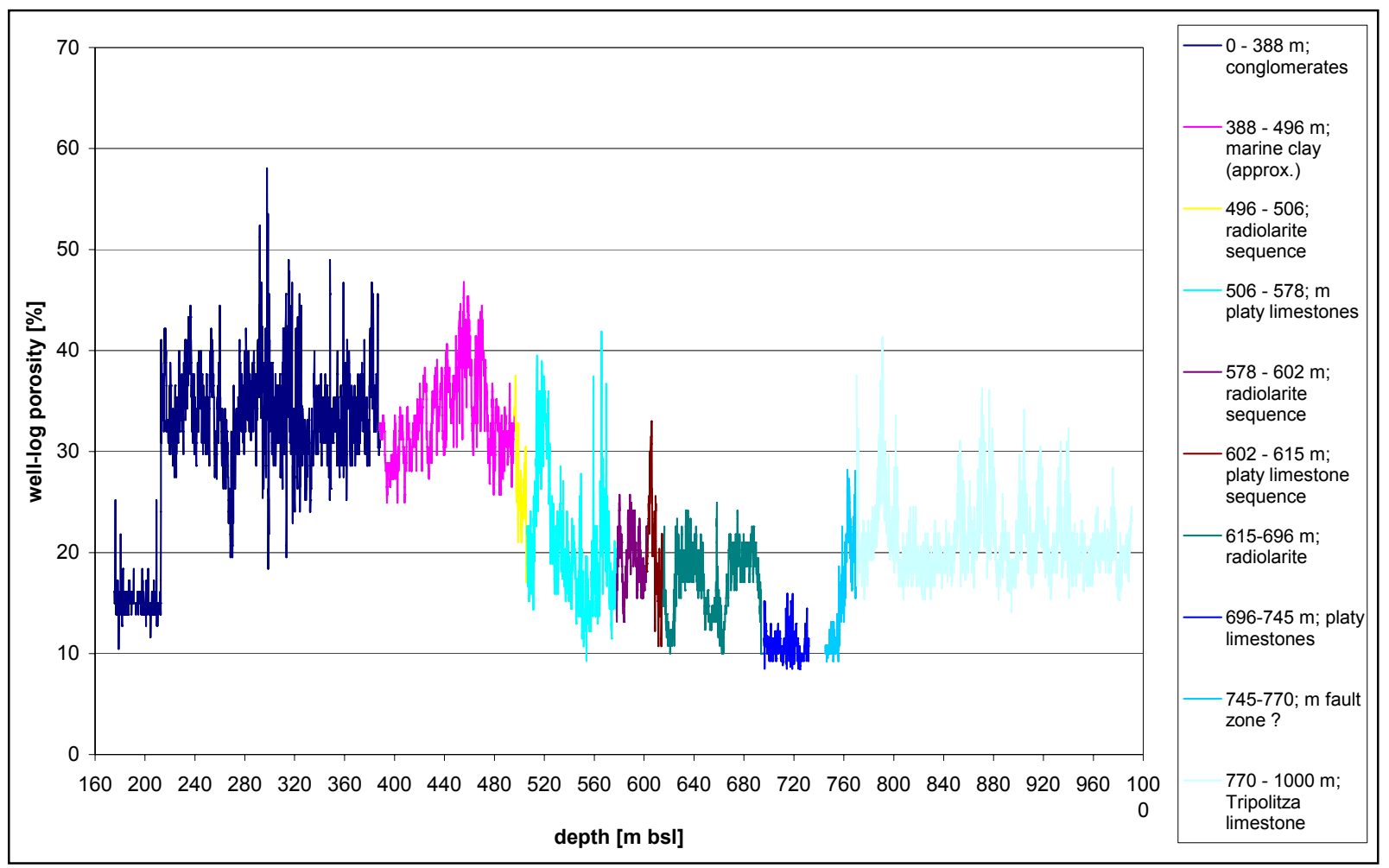

Fig. V.21: Formation porosity derived from the sonic log by the Wyllie time average equation referring to the lithology in the prevailing borehole depth of AIG10. 
A close inspection to the results show that the heterogeneity of the lithological succession in AIG10 is indeed noticeable in the graphs (Fig. V.21). The first part of the graph show approx. 15\% porosity and can be correlated to sandy to clayey intercalations in the conglomerates at about $180-220 \mathrm{~m}$ bsl. The ranging of the following conglomerates then could be determined to $20-55 \%$ and an average value of $40 \%$ is chosen. The $108 \mathrm{~m}$ thick marine clay sequence is based on a approximation assuming a transit time of $55.5 \mu \mathrm{s} / \mathrm{ft}$, which has resulted in a plausible value of $+/-35 \%$.

Three sections of the borehole where radiolarite is prevailing has shown alternating porosity values. As seen in the detailed analysis of the litho-log by gamma ray the sequence from 496-506 m consists of radiolarite which are partly clayey. This would explain the higher values in formation porosity at this sequence where up to $26 \%$ is determined from the sonic log. The radiolarite sequence from $578 \mathrm{~m}$ to $602 \mathrm{~m}$ show $19 \%$ average formation porosity but is located above a thrust fault which could result in overestimated values. A relatively solid radiolarite sequence is encountered from $615-696 \mathrm{~m}$ depth. The average formation porosity resulted in $16 \%$ but clayey sequences are incorporated here as well (green graph in Fig. V.21). Therefore, it is decided to pick clearly defined sonic log fragments where radiolarite successions are without disturbance of secondary clay minerals. This method has resulted in a formation porosity for the radiolarite of $15 \%$.

The platy limestones are often accompanied with marls and marly intercalations causing higher porosity values mainly in the upper parts of AIG10. The high variation of $10-40(?) \%$ from 506-578 $\mathrm{m}$ is an indication of this heterogeneity. A pure platy limestone succession is also cored in the depth interval of $696-745 \mathrm{~m}$. At this part, Fig. V.21 show a formation porosity of $10 \%$ which is chosen for the average value in the further calculations.

The relative conform Tripolitza formation from $772 \mathrm{~m}$ depth is reflected in a relatively smooth variation around $20 \%$ formation porosity. Peaks of $40 \%$ at about $791 \mathrm{~m}$ may be connected to cavities which also were derived from the graphical log analysis. In the further calculations formation porosity of $20 \%$ is used for the Tripolitza limestones.

A summary of the averaged well log porosities derived from the Wyllie time average equation of Fig. V.21 is given in Tab. V.12.

Tab. V.12: Summary of averaged well-log porosities derived from sonic log determination.

\begin{tabular}{l|c|c}
\hline lithology & transit time $\Delta t_{m a}[\mu \mathrm{s} / \mathrm{ft}]$ & averaged well-log porosity \\
\hline conglomerate & 50.0 & 0.40 \\
marine clay (approximated) & -- & 0.35 \\
radiolarite & 55.5 & 0.15 \\
platy limestone & 47.5 & 0.10 \\
Tripolitza limestone & 43.5 & 0.20 \\
water / drilling mud & 189 & -- \\
\hline
\end{tabular}




\section{V.3.3 DTS temperature logging and heat flow determination}

The continuous temperature-depth log performed in AIG10 provides detailed information of the subsurface thermal structure, which for example, is necessary for reliable heat-flow determinations and rock thermal properties and, of course, are essential for the preparation of the thermo-hydraulic model. The temperature logging was obtained after one year of temperature adjustment and under shut-in conditions reflecting subsurface conditions not affected by drilling and artesian flow. In AIG10 the Distributed optical fibre Temperature Sensing technique (DTS) was used which has been introduced within the recent years as a new technology for the measurement of temperature in boreholes (e.g. Hurtig et al., 1993; Förster et al., 1997). The DTS technique is based on the Optical Time Domain Reflection concept (OTDR). This technique uses the optical fiber as the sensing element with the intensity of the Raman back-scattered light of a laser pulse as a temperature dependent parameter. The DTS principle differs completely from the conventional temperature logging techniques. In contrast to conventional logging where temperatures are obtained sequentially, perhaps during a time period of hours, the DTS data reflect instantaneous temperatures at the selected depth interval along the fiber length (depth) in the borehole (Förster et al., 1997).

The DTS system used for the well logging in AIG10 consists of a gradient-index fiber with a temperature limit from $-100{ }^{\circ} \mathrm{C}$ to $+750{ }^{\circ} \mathrm{C}$. The transmitting and recording device for measuring the intensity of the Raman backscattered light is sending the information to the PC, acting as a data acquisition and controlling unit for the DTS device. The laser pulse through the optical fiber has a wavelength of $1064 \mathrm{~nm}$, and the pulse duration of the laser light is $10 \mathrm{~ns}$. The DTS unit is coupled with an optical-fiber cable (the distributed sensor) to a wireline on surface whereas recording direction is from bottom-up. The recording interval was $1 \mathrm{~m}$. According to the manufacturer the DTS system allows temperature measurements with a resolution of plus or minus 0.1 degree $\mathrm{C}$ and an absolute temperature precision of about 0.3 degree C. For details of the principle of measurement the reader is referred to Hurtig et al. 1994 and Förster et al., 1997.

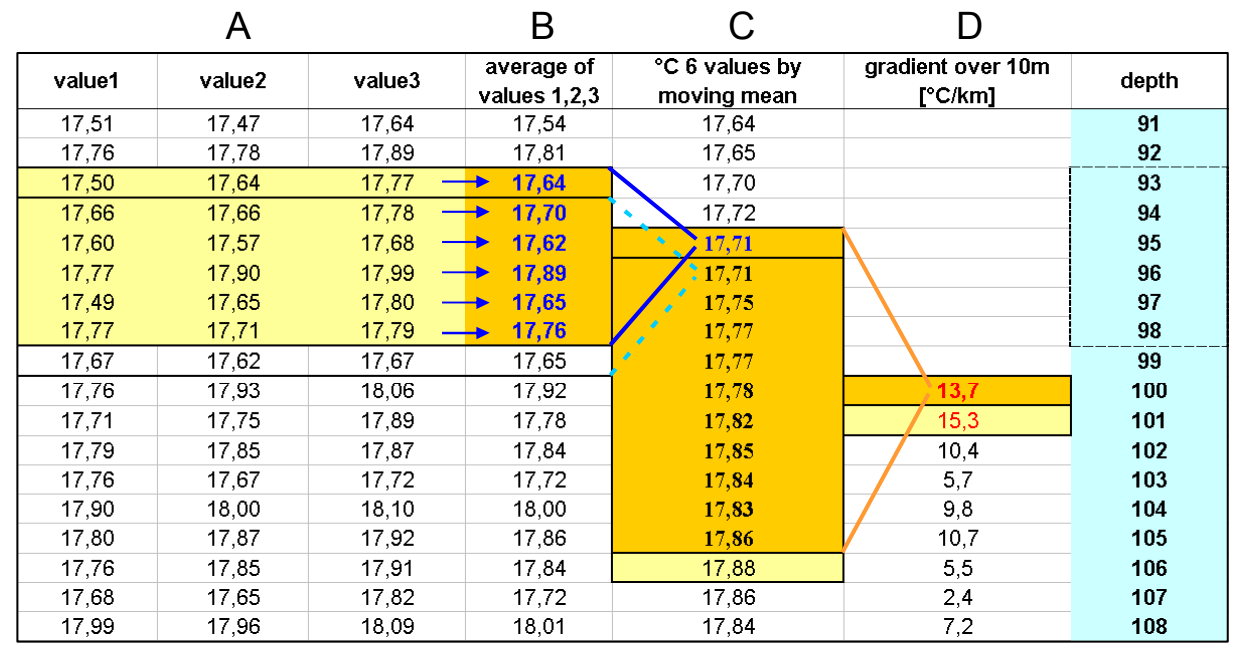

Fig. V.22: Principle of the interval method applied to the temperature gradient data. 
The temperature gradient is defined as the rate of change in temperature with depth. The temperature gradient can be expressed in ${ }^{\circ} \mathrm{C} / \mathrm{km}$ or $\mathrm{K} / \mathrm{km}$. In general the geothermal gradient varies from place to place depending on heat flow and thermal conductivity of the depth interval. The measured DTS data are plotted at $1 \mathrm{~m}$ intervals. The gradients were smoothed by a $10 \mathrm{~m}$ running average. Fig. V.22 displays the principle of the method. The three DTS-measured values 1, 2, and 3 ((A) in Fig. V.22) are averaged to one value. Six averaged values of a $5 \mathrm{~m}$ interval (B) then offer the number for the moving mean (C). Eleven numbers of them then finally result in the moving mean over $10 \mathrm{~m}$ for the thermal gradient (D), which is plotted versus depth. The geothermal gradient versus depth obtained at the AIG10 borehole is shown in Fig. V.23. The temperature log showing in the left of the figure is a semilinear curve not depicting any zones of thermal perturbations due to upward or downward flow.
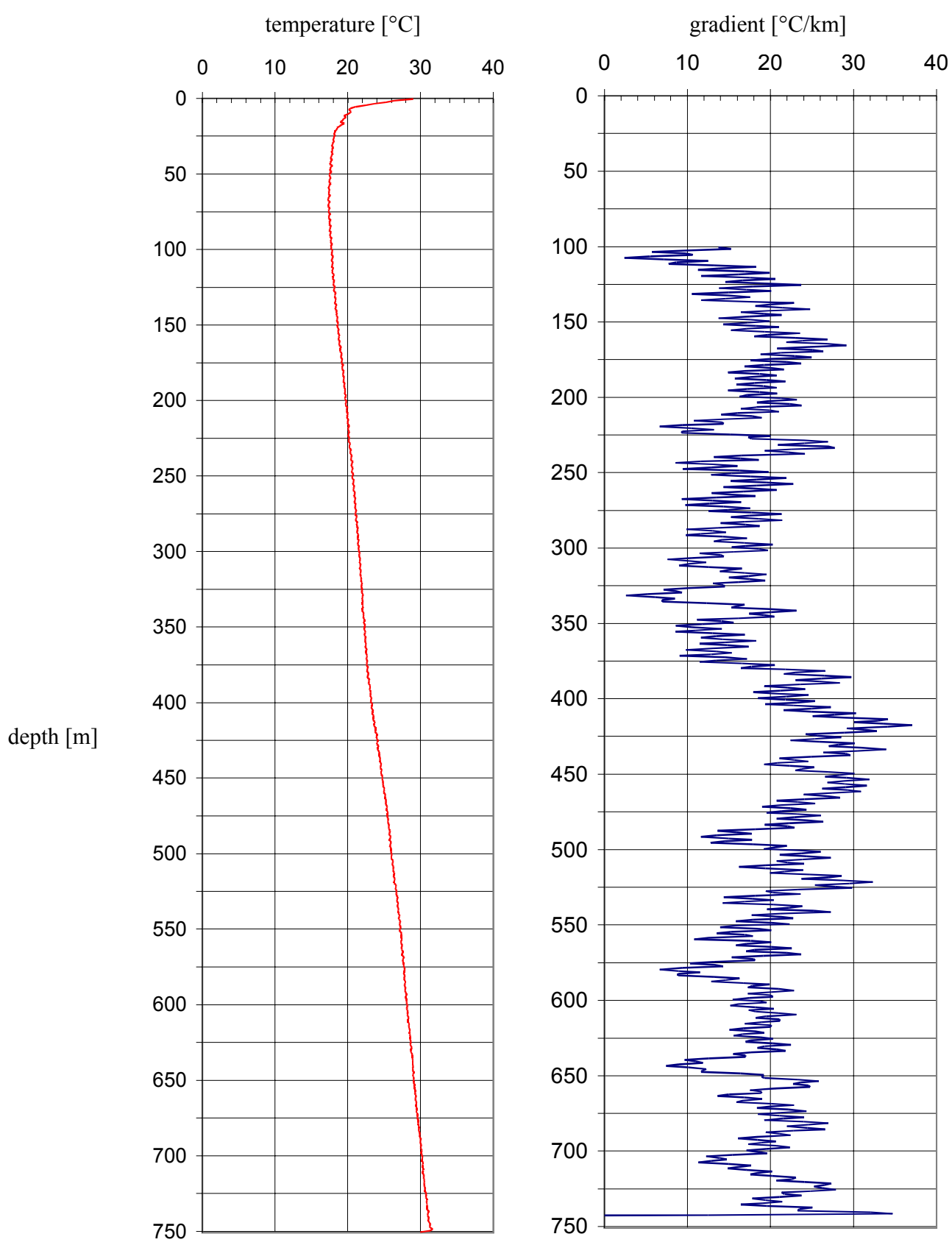

Fig. V.23: DTS temperature log and temperature gradient $\left[{ }^{\circ} \mathrm{C} / \mathrm{km}\right]$ derived from AIG10 borehole. 
The gradient plot in the AIG10 borehole shows remarkable differences in the temperature gradient. The conglomerates show a temperature gradient of $10-20{ }^{\circ} \mathrm{C} / \mathrm{km}(100-388 \mathrm{~m}$ depth) whereas the gradient of the marine clay (388-496 m depth) has values of $25-35{ }^{\circ} \mathrm{C} / \mathrm{km}$. The rocks of the OlonosPindos formation show intervals with gradients around $20^{\circ} \mathrm{C} / \mathrm{km}$ but overall range from $6-32{ }^{\circ} \mathrm{C} / \mathrm{km}$. The overall gradient pattern matches the stratigraphic sequence and lithologies well. Thus, variations in the temperature gradient can be related to chances in the lithology (Fig. V.25).

With the aid of the other logs available and due to a plausibility and sensitivity check during the heat flow determination the AIG10 litho-log was finally divided into heat flow determination zones (Fig. V.24a-d): I: 160-380 m; II: 380-485 m; III: 485-700 m; IV: 700-740 m. The regression analysis of the gradients resulted in average gradients for the four intervals. All coefficients of determination (Rsquared) are satisfying. The temperature gradient for the conglomerate interval is calculated to $17.4^{\circ} \mathrm{C} / \mathrm{km}$ (Fig. V.24a), the gradient for marine clay is $29.2^{\circ} \mathrm{C} / \mathrm{km}$ (Fig. V.24b). The very heterogeneous interval from $485-700 \mathrm{~m}$ has a gradient of $20.2^{\circ} \mathrm{C} / \mathrm{km}$ (Fig. V.24c) and finally, the platy limestones of $22.3{ }^{\circ} \mathrm{C} / \mathrm{km}$ (Fig. V.24d).
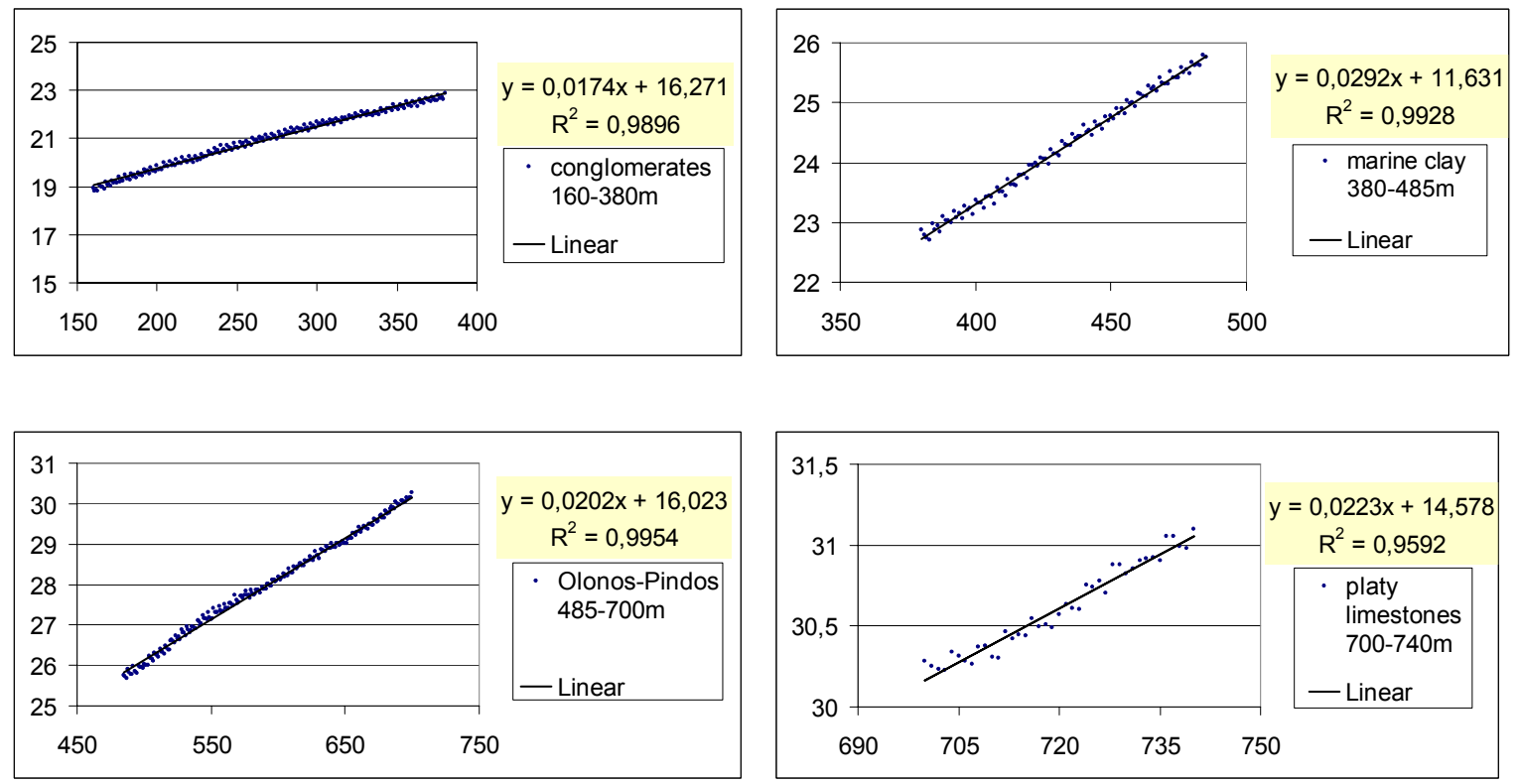

Fig. V.24 a-d: Temperature gradient for four lithological intervals based on regression analysis. 


\section{Heat flow determination}

The heat flow $\mathrm{q}$ is defined as the amount of heat $\mathrm{Q}$ per unit time $\mathrm{t}$ which is transported through a transverse section $\mathrm{A}$ an is in general measured in $\mathrm{mW} / \mathrm{m}^{2}$. The transmission of heat across the transverse section referred to as heat conduction. The law of heat conduction in a steady-state temperature field is known as the Fourier's law and states, that heat flow is directly proportional to the gradient of the temperature difference $\mathrm{dT} / \mathrm{x}$ :

$$
\begin{array}{lll}
q=\lambda \cdot \frac{\Delta T}{x} & \quad \text { where: } & \\
q: & \text { heat flow } & {\left[\mathrm{mW} / \mathrm{m}^{2}\right]} \\
\Delta \mathrm{T}: & \text { temperature difference causing the heat transfer } & {[\mathrm{K}]} \\
\frac{\Delta T}{x}: & \text { temperature gradient } & {[\mathrm{K} / \mathrm{m}]} \\
\lambda: & \text { constant of proportionality }=\text { thermal conductivity } & {[\mathrm{W} / \mathrm{m} / \mathrm{K}]}
\end{array}
$$

The constant of proportionality $\lambda$ describes the ability to transport a quantity of heat and is referred to as thermal conductivity $[\mathrm{W} / \mathrm{m} / \mathrm{K}]$. Using this mathematical equation it is possible to calculate the heat flow values for the selective lithological intervals by a simple multiplication of the temperature gradients (Fig. V.24a-d) with the thermal conductivities $\lambda$. The thermal conductivities are derived from laboratory measurements on core and surface samples and will be discussed in the following chapter VI (values are displayed in Tab. VI.2). A summary and the results of heat flow calculations relating to the selective depth intervals and lithology are displayed in Tab. V.13.

The average heat flow for the AIG10 profile is $50.5 \mathrm{~mW} / \mathrm{m}^{2}$ if the interval heat-flow values are averaged arithmetically. The interval values shown in the table differ largely giving rise to a large

\begin{tabular}{|c|c|c|c|c|c|}
\hline $\begin{array}{l}\text { Depth } \\
\text { Interval } \\
\text { (m) } \\
\end{array}$ & Stratigraphy & Lithology & $\begin{array}{l}\text { T Gradient } \\
\left({ }^{\circ} \mathrm{C} / \mathrm{km}\right)\end{array}$ & $\begin{array}{l}\text { Thermal } \\
\text { Cond. } \\
(W / m / K)\end{array}$ & $\begin{array}{l}\text { Heat Flow } \\
\left(\mathrm{mW} / \mathrm{m}^{2}\right)\end{array}$ \\
\hline $160-380$ & $\begin{array}{l}\text { Pleistocene Gilbert-type } \\
\text { delta conglomerates }\end{array}$ & conglomerate & 17.4 & 2.4 & 41.8 \\
\hline $380-485$ & $\begin{array}{l}\text { Pleistocene marine-lagoonal } \\
\text { sediments }\end{array}$ & $\begin{array}{l}\text { sandy to silty } \\
\text { clays }\end{array}$ & 29.2 & 1.7 & 49.6 \\
\hline $485-700$ & Olonos-Pindos Radiolarite & $\begin{array}{l}\text { radiolarite/ } \\
\text { limestone/marl/ } \\
\text { claystone }\end{array}$ & 20.2 & 2.5 & 50.5 \\
\hline $700-740$ & $\begin{array}{l}\text { Olonos-Pindos Platy } \\
\text { Limestones }\end{array}$ & limestone & 22.3 & 2.6 & 60.0 \\
\hline
\end{tabular}
standard deviation. The final modeling will investigate whether the differences in heat flow are entirely the result of not having picked properly the in situ thermal conductivity for some intervals or whether some of the intervals are affected by fluid flow.

Tab. V.13: Heat flow of depth intervals derived from geothermal gradient along the AIG10 borehole profile. 


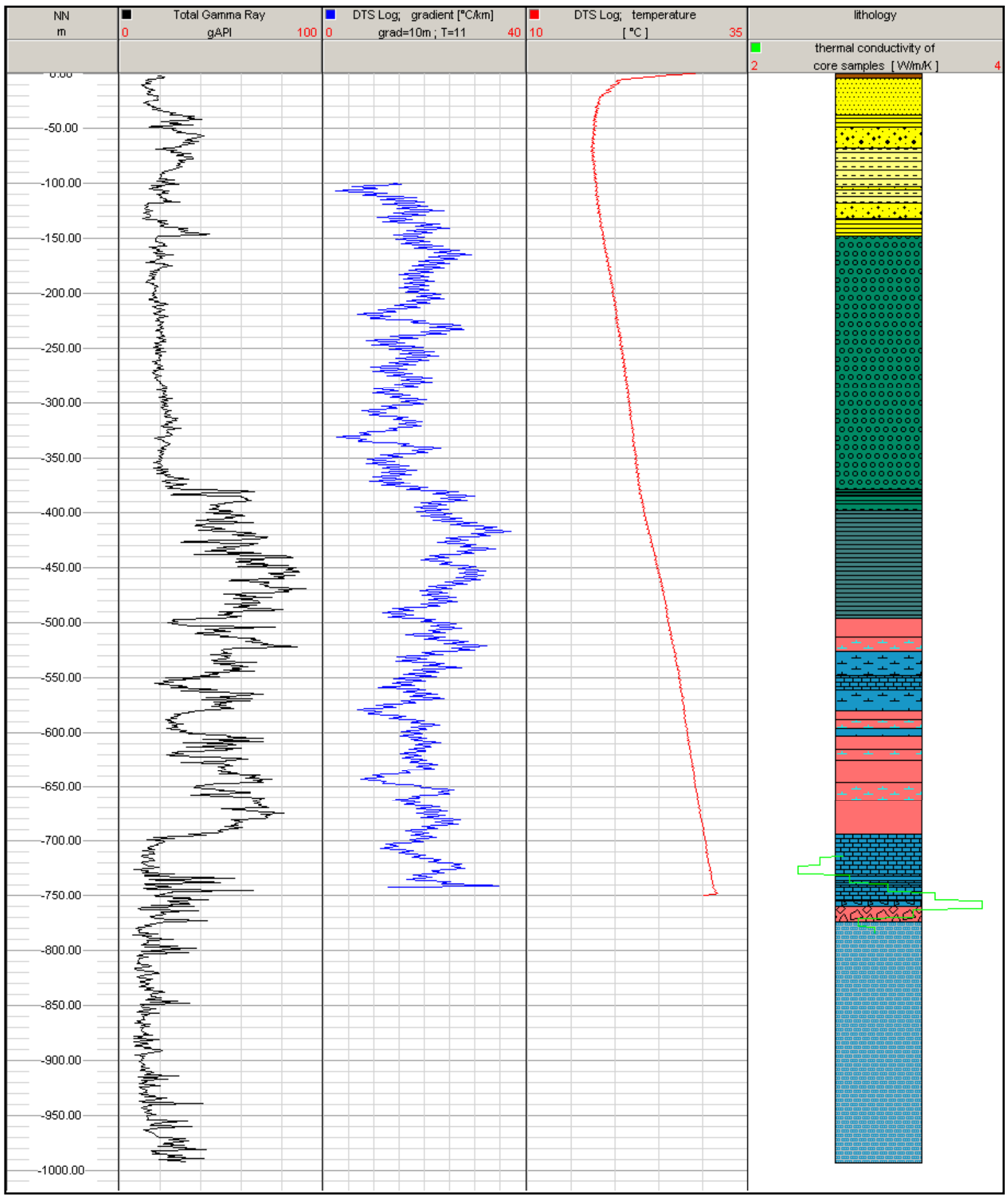

Fig. V.25: Plots of temperature (red) and geothermal gradient (blue) versus depth as obtained by DTS-logging. The plots are compared to the gamma log and major lithology. Below $750 \mathrm{~m}$ the borehole was blocked at the time of DTS measurement, so that here are no readings to be composed with the gamma log. (Legend see Appendix). 


\section{Laboratory measurements of thermal conductivity and porosity}

\section{VI.1 Methods}

Because the thermal conductivity of rocks is a basic parameter affecting subsurface temperatures, the determination of this parameter is compulsive for the numerical model analysis in this work. Laboratory-derived petrophysical properties for selective core- and surface samples were obtained for the determination of formation thermal conductivity. The method used is to determine the thermal conductivity on the single lithotypes and then averaged according to the proportions of the lithotype mixture (Norden \& Förster, 2006).

Core- and surface samples where analyzed at the GFZ laboratory using Thermal Conductivity Scanning (TCS) technique (Lippmann \& Rauen GbR). TCS is based on scanning a sample surface with a focused, mobile, and continuously operated constant heat source in combination with a temperature sensor (Popov et al., 1983, 1985).

Fig. VI.1 displays the principle of operation (Popov et al., 1999). The heat source and the sensor move with the same speed relative to the sample and at a constant distance to each other. The temperature sensor displays the value of the maximum temperature rise along the heating line behind the source.

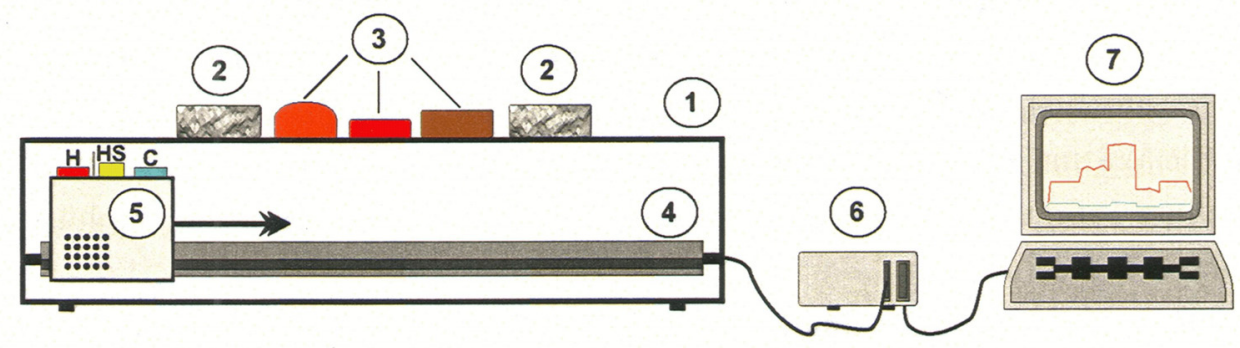

Fig. VI.1: Principle of the optical scanning device for Thermal Conductivity Scanning (TCS) after Popov et al., 1999:

1 Measuring platform;

2 Standard with known thermal conductivity;

3 Surface and core samples AIG10;

4 Engine;

5 Measuring unit with infrared emitting heat source (HS) and infrared recording radiometers $\mathrm{C}$ (cold), $\mathrm{H}$ (hot);

6 Interface and PC 7; 
The maximum temperature rise $(\Theta)$ is determined by the relationship:

$\Theta=\frac{Q}{2 \pi \cdot x \cdot \lambda}$

where $\mathrm{Q}$ is the source power and $\mathrm{x}$ the distance between source and sensor. The measured samples and a reference standard with known thermal conductivity, $\lambda_{R}$, are aligned along the scanning direction.

The thermal conductivity of each sample then can be determined from $\lambda_{R}$, given that the ratio of $\Theta / \Theta_{R}$ is directly proportional to the ratio of the electrical signals $U$ and $U_{R}$ :

$$
\lambda=\lambda_{R} \cdot\left(\frac{\Theta_{R}}{\Theta}\right)=\lambda_{R} \cdot\left(\frac{U_{R}}{U}\right)
$$

This method excels in its ease in use, which is high speed in operation, noncontact mode of measurement, and the ability to measure directly on a core or plain outcrop sample showing the heterogeneity of the rock sample along the scanning line. The samples were sawed, and on the plain surfaces stripes of acrylic varnish $10-15 \mathrm{~mm}$ wide and $30 \mu \mathrm{m}$ thick were painted that are identical with the ones used on the standards. Sample thickness was $>3 \mathrm{~cm}$. The error of determination is $<3 \%$. Porosity and density were determined by mass change of dry and saturated samples according to the Archimedes' method.

\section{VI.2 Results}

Thermal conductivity $\lambda$ (TC) was determined under saturated conditions on 32 rock samples typical for each respective geological formation (Tab. VI.1): 4 samples are from the Corinth graben fill, 14 samples are from Olonos-Pindos Platy Limestone and Radiolarite Formation and 14 from the Tripolitza Formation.

The TC determined on the dry samples, first is corrected to water saturated conditions using the geometric mean model (e.g. Woodside and Messmer, 1961a, 1961b) and a laboratory measured porosity, as given in Tab. VI.1:

The thermal conductivity according to the geometric mean is:

$$
\lambda_{\text {geo }}=\lambda_{\text {matrix }}^{1-\phi} \cdot \lambda_{\text {pore }}^{\phi} \quad \text { where }
$$

$\begin{array}{ll}\lambda_{\text {geo }}: & \text { thermal conductivity according to the geometric mean } \\ \lambda_{\text {matrix }}: & \text { thermal conductivity of the matrix } \\ \lambda_{\text {pore }}: & \text { thermal conductivity of the pore fill (here water) } \\ \phi: & \text { matrix porosity }\end{array}$


The thermal conductivity derived for the single lithotypes are averaged according to the proportions of the lithotype mixture (Tab. VI.2). These values represent the average matrix TCs for each lithological formation and were needed as inputs into the model software. Later on, formation TCs were calculated by upscaling the lithotype values. For those formations where there was a discrepancy between sample porosity and well-log porosity, the TC was corrected for the well log porosity (the better in-situ value) using again the matrix TC (Tab. VI.2).

Tab. VI.1: TC, porosity, density and lithotype of investigated samples.

\begin{tabular}{|c|c|c|c|c|c|}
\hline \multicolumn{6}{|c|}{$\begin{array}{l}\text { KA (1-7) = AIG10 core samples; } \\
\text { KAG }(1-3)=\text { AIG10 core samples (without clear depth correlation); } \\
\text { S (1-12) = surface samples Tripolitza Unit; } \\
P(1-12)=\text { surface samples Klokos area, Olonos-Pindos Formation; } \\
(\text { A10) = number of outcrop from mapped area }\end{array}$} \\
\hline $\begin{array}{c}\text { Number } \\
\text { of } \\
\text { sample }\end{array}$ & $\begin{array}{l}\text { Depth } \\
{[\mathrm{m}]}\end{array}$ & $\begin{array}{c}\mathrm{TC} \\
\text { (dry cond.) } \\
{[\mathrm{W} / \mathrm{m} / \mathrm{K}]}\end{array}$ & $\begin{array}{c}\text { Porosity } \\
(\%)\end{array}$ & $\begin{array}{l}\text { Density } \\
\left(\mathrm{g} / \mathrm{cm}^{3}\right)\end{array}$ & Formation / Lithology \\
\hline KA 1 & 739.0 & 2.86 & 0.06 & 2.71 & Olonos-Pindos platy limestone \\
\hline KA 2 & 739.5 & 2.78 & 0.20 & 2.70 & Olonos-Pindos platy limestone \\
\hline KA 3 & 739.3 & 2.16 & 3.63 & 2.62 & Olonos-Pindos marlstone \\
\hline KA 4 & 714.2 & 2.73 & 0.49 & 2.72 & Olonos-Pindos limestone \\
\hline KA 5 & $\sim 763.0$ & 3.86 & 0.96 & 2.61 & Olonos-Pindos radiolarite \\
\hline KA 6 & $786 / 787$ & 2.98 & 0.66 & 2.70 & Tripolitza limestone \\
\hline KA 7 & $782.9-784.5$ & 2.83 & 0.64 & 2.67 & Tripolitza limestone \\
\hline KAG 1 & $774.9-777.8$ & 2.87 & 0.49 & 2.70 & Tripolitza limestone \\
\hline KAG 2 & $780.7-782.9$ & 2.84 & 0.39 & 2.70 & Tripolitza limestone \\
\hline KAG 3 & 733.0 & 2.32 & 2.38 & 2.71 & Olonos-Pindos marlstone \\
\hline S 1 & - & - & - & - & Tripolitza cataclasit \\
\hline S 2 & - & $2.76 ?$ & 0.66 & 2.69 & Tripolitza dolomite \\
\hline S 3 & - & - & - & - & Tripolitza dolomite/limestone \\
\hline S 4 & - & - & - & - & Tripolitza dolomite/limestone \\
\hline S 5 & - & 2.62 & 1.12 & 2.99 & Tripolitza dolomite \\
\hline S 6 & - & 3.61 & 1.64 & 2.77 & Tripolitza dolomite \\
\hline S 7 & - & $2.84 ?$ & 2.64 & 2.74 & Tripolitza limestone \\
\hline S 8 & - & 2.26 & 11.39 & 2.40 & Tripolitza flysch \\
\hline S 9 & - & $2.66 ?$ & 7.01 & 2.48 & Tripolitza flysch \\
\hline S 10 & - & 2.92 & 0.21 & 2.71 & Tripolitza limestone \\
\hline P 1 & - & $2.13 ?$ & 14.66 & 2.26 & Pliocene/Pleistocene delta conglomerate \\
\hline P 2 & - & 3.89 & 0.86 & 2.61 & Olonos-Pindos radiolarite \\
\hline P 3 & - & 3.36 & 0.93 & 2.65 & Olonos-Pindos Eocene flysch sandstone \\
\hline $\mathrm{P} 4$ & - & 2.70 & 4.67 & 2.58 & Olonos-Pindos platy limestone \\
\hline P 5 & - & 2.43 & 5.06 & 2.57 & Olonos-Pindos platy limestone \\
\hline P 6 & - & 2.54 & 0.44 & 2.21 & Olonos-Pindos silty marl \\
\hline P 7 & - & 3.55 & 1.60 & 2.60 & Olonos-Pindos black chert \\
\hline P 8 & - & 3.39 & 2.64 & 2.54 & Olonos-Pindos radiolarite \\
\hline P 9 & - & $3.17 ?$ & 5.74 & 2.52 & Pliocene/Pleistocene delta conglomerate \\
\hline P 10 & - & 2.77 & 6.75 & 2.48 & Olonos-Pindos Eocene flysch sandstone \\
\hline P 11 & - & $1.71 ?$ & 16.14 & 2.23 & Pliocene/Pleistocene delta conglomerate \\
\hline P 12 & - & $2.70 ?$ & 4.98 & 2.54 & Pliocene/Pleistocene delta conglomerate \\
\hline
\end{tabular}


Tab. VI.2: Laboratory derived and porosity corrected values for thermal conductivity used for modeling.

\begin{tabular}{|c|c|c|c|c|c|c|c|}
\hline Sample & Lithotype & $\begin{array}{c}T C-L a b a t \\
20^{\circ} \mathrm{C} \\
{[\mathrm{W} / \mathrm{m} / \mathrm{K}]}\end{array}$ & $\begin{array}{c}\text { Lab. - } \\
\text { Porosity } \\
(\%)\end{array}$ & $\begin{array}{c}\text { Water at } \\
20^{\circ} \mathrm{C} \\
{[\mathrm{W} / \mathrm{m} / \mathrm{K}]}\end{array}$ & $\begin{array}{c}T C \\
\text { matrix } \\
\text { Phi }=0\end{array}$ & $\begin{array}{l}\text { Well-Log } \\
\text { Porosity }\end{array}$ & $\begin{array}{c}T C \\
{[W / m / K]}\end{array}$ \\
\hline P1 & congl. & 2.13 & 14.70 & 0.6 & & & \\
\hline P9 & congl. & 3.17 & 5.70 & 0.6 & & & \\
\hline P11 & congl. & 2.74 & 16.10 & 0.6 & & & \\
\hline \multirow[t]{2}{*}{ P12 } & congl. & 2.74 & 5.00 & 0.6 & & & \\
\hline & average & 2.43 & 10.40 & 0.6 & 2.86 & 0.40 & 1.53 \\
\hline assumed & clay & 1.71 & 1.50 & 0.6 & 1.74 & 0.15 & 1.71 \\
\hline $\mathrm{P} 2$ & O-P radiol. & 3.61 & 0.86 & 0.6 & & & \\
\hline P7 & O-P radiol. & 3.55 & 1.60 & 0.6 & & & \\
\hline \multirow[t]{2}{*}{ P8 } & O-P radiol. & 3.39 & 2.64 & 0.6 & & & \\
\hline & average & 3.51 & 1.70 & 0.6 & 3.62 & 0.15 & 2.77 \\
\hline P4 & O-P pl. limestone & 2.70 & 4.68 & 0.6 & & & \\
\hline P5 & O-P pl. limestone & 2.43 & 5.06 & 0.6 & & & \\
\hline \multirow[t]{2}{*}{ P6 } & O-P pl. limestone & 2.54 & 0.44 & 0.6 & & & \\
\hline & average & 2.55 & 3.39 & 0.6 & 2.70 & 0.10 & 2.32 \\
\hline KA4 & O-P pl. limestone & 2.73 & 0.49 & 0.6 & & & \\
\hline KA1 & O-P pl. limestone & 2.86 & 0.06 & 0.6 & & & \\
\hline \multirow[t]{2}{*}{ KA2 } & O-P pl. limestone & 2.78 & 0.20 & 0.6 & & & \\
\hline & average all 6 & 2.67 & 0.25 & 0.6 & 2.68 & & \\
\hline KAG3 & O-P marlstone & 2.32 & 2.38 & 0.6 & & & \\
\hline \multirow[t]{2}{*}{ KA3 } & O-P marlstone & 2.16 & 3.63 & 0.6 & & & \\
\hline & average & 2.24 & 3.39 & 0.6 & 2.33 & & \\
\hline $\mathrm{S} 2$ & Tripol. limestone & 2.76 & 0.66 & 0.6 & & & \\
\hline S5 & Tripol. limestone & 2.62 & 1.12 & 0.6 & & & \\
\hline S7 & Tripol. limestone & 2.84 & 2.64 & 0.6 & & & \\
\hline \multirow[t]{2}{*}{ S10 } & Tripol. limestone & 2.92 & 0.21 & 0.6 & & & \\
\hline & average & 2.79 & 1.16 & 0.6 & 2.86 & 0.20 & 2.09 \\
\hline
\end{tabular}

Obviously, in the conglomerates, the laboratory average porosity of samples (10.4\%) differs most from the formation porosity from well $\log (40 \%)$. Given a matrix thermal conductivity (TCmatrix) of $2.43 \mathrm{~W} / \mathrm{m} / \mathrm{K}$ the in-situ formation TC yields $1.53 \mathrm{~W} / \mathrm{m} / \mathrm{K}$. For the clay sequence in AIG10 a value of $1.7 \mathrm{~W} / \mathrm{m} / \mathrm{K}$ was assumed. The Olonos-Pindos Formation is considered to be composed of radiolarite/limestone/marl/clay in the proportions $1: 1: 1: 1$. The mean formation thermal conductivity yields $2.77 \mathrm{~W} / \mathrm{m} / \mathrm{K}$ for the radiolarite-limestone sequence and $2.32 \mathrm{~W} / \mathrm{m} / \mathrm{K}$ for the platy limestone sequence. The Tripolitza limestone of the lowermost litho-log is calculated to $2.09 \mathrm{~W} / \mathrm{m} / \mathrm{K}$ (Tab. VI.2). 


\section{Numerical thermo-hydraulic model}

\section{VII.1 Objectives}

Numerical modeling of groundwater flow and heat transport is useful to get insights in the subsurface processes that may be typical for an investigated area. In the case of the Corinth area, model calibration as well as sensitivity and plausibility checks allow a prediction on how the thermohydraulic system in a seismically active zone is running and how thermo-hydraulic conditions affect the heat flow. Surface heat-flow density is unknown in the northern Peloponnesus (Fytikas \& Kolios, 1979). It is also unknown whether the water flow in aquifers results in strong heat advection signals in the temperature field (e.g. Stiros, 1991). The goal of the numerical modeling therefore is to get insight in the coupling of thermal and hydraulic conditions in the area based on field data.

\section{VII.2 Conceptual hydrogeological model}

The conceptual hydrogeological model (Fig. VII.1) is based on a SSW-NNE oriented, $14 \mathrm{~km}-$ long cross-section through the location of the AIG10 borehole (chapter IV.3), which is located in the centre of the model. The model includes the position of the geological formations and the graben deposits as well as the arrangement of the thrust faults and normal faults (Giurgea et al., 2004).

The model domain is subdivided into the area south of the Eliki Fault (Trapeza Mt.), the area between the Eliki Fault and the Aigion Fault, and the area north of the Aigion Fault ending in the Gulf of Corinth. The adjacent area to the south is of high relief (Klokos Mt.) and the effects from this area are considered in the model along the southern model boundary.

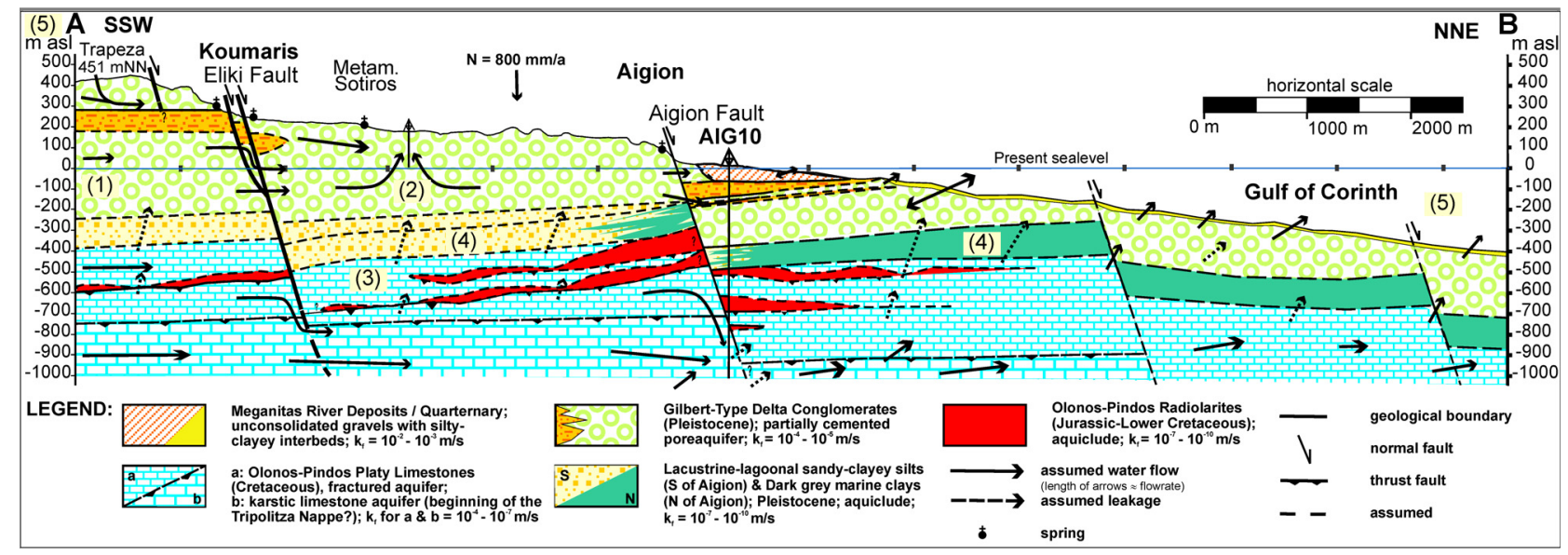

Fig. VII.1: Conceptual hydrogeological model stretching between the Eliki fault and offshore faults in the Gulf of Corinth (Giurgea et al., 2004, modified). 
While the hydraulic conductivity of the aquifers was determined by hydraulic tests, the respective parameters for the aquicludes are approximated only, reflecting the hydrogeological map south of Aigion (Fig. VII.2). The unconsolidated Quaternary deposits (fluvio-lacustrine, soil, river deposits) at the top of the model (Fig. VII.1) are sometimes intercalated with silty or clayey beds, hence the hydraulic conductivities are in the range of $10^{-2} \mathrm{~m} / \mathrm{s}$ to $10^{-3} \mathrm{~m} / \mathrm{s}$. The first main groundwater catchment is in the Gilbert-type delta conglomerates. Here, the groundwater from the hinterland mingles with surface infiltration water. The hydraulic conductivities of the conglomerate unit is in the range of $10^{-4}$ $\mathrm{m} / \mathrm{s}$ to $10^{-5} \mathrm{~m} / \mathrm{s}$. Below the conglomerates are lacustrine-lagoonal sandy clays (south of Aigion) and marine clays (north of Aigion). Both are major aquicludes for which hydraulic conductivities of $10^{-7}$ $\mathrm{m} / \mathrm{s}$ to $10^{-10} \mathrm{~m} / \mathrm{s}$ are assumed. The aquicludes are $>100 \mathrm{~m}$ thick and act as vertical hydraulic barriers, separating the conglomerates above from the Olonos-Pindos Formation below. The high pressure in the system suggests the existence of vertical semi-permeable leakages allowing the water to interact between the two compartments.

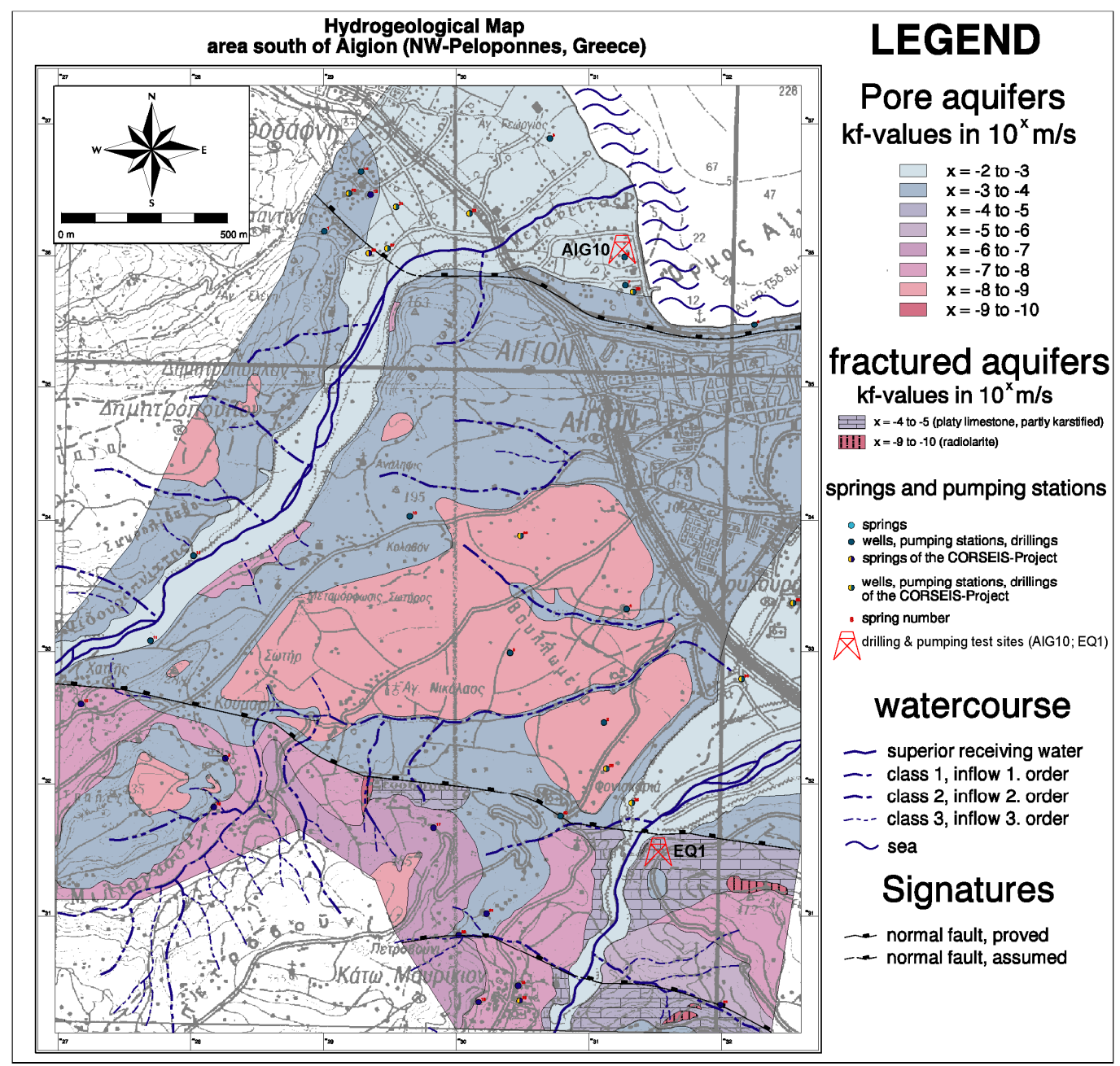

Fig. VII.2: Hydrogeological map of the northern part of the study area (Unkel, 2002 and N. Kostas (IGME), 2002, personal communication). The aquifers can be separated into pore aquifers (Neogene and rift sediments) and fractured aquifers (Olonos-Pindos Formation). The hydraulic conductivities $\left(\mathrm{k}_{\mathrm{f}}\right)$ are derived from hydraulic tests and hydrogeological filed studies. 
Below the aquicludes is the Olonos-Pindos Formation comprising the Olonos-Pindos Limestone Formation and the Radiolarite Formation. The geological and hydrogeological field studies have shown that the platy limestones below the Corinth graben sediments are tectonically very stressed showing many $\mathrm{W}$ - NW verging folds and a significant fracturing, suggesting that they form a fractured aquifer system. The hydrogeological interpretation of the block-faulted system in the hinterland of Aigion (Giurgea et al., 2003, Giurgea et al., 2004) is that the faults that have experienced cataclastic deformation in the limestones, followed by fluid circulation and cementation, seem to act more or less as hydrogeological barriers whereas brecciated fault zones are more permeable than unfaulted zones. The hydraulic conductivities in the Platy Limestone Formation, derived from the pumping tests EQ1 (Selinous valley) and AIG10L (AIG10 borehole testing) yield $10^{-7} \mathrm{~m} / \mathrm{s}$ to $10^{-4} \mathrm{~m} / \mathrm{s}$. These values have confirmed that the Olonos-Pindos limestones constitute a fractured aquifer. Assuming water recharge and high pressure from the south (Klokos relief), it is expected that groundwater flow is parallel to the clay aquicludes and parallel in each aquifer system above and below. Leakages can be assumed where the limestone is not associated with marls and exhibits less cataclastic zones.

The Aigion fault zone is regarded to be higher permeable parallel along the fault zone. As springs appear very often in lines along outcropping fault planes it can be concluded that the water rises up to the surface parallel to the impermeable fault plane. Similar conditions were observed on outcrop along the "Ponti" fault in the limestones, and also the cores retrieved from the AIG10 borehole indicate this direction of flow. Thus, the permeability of the Olonos-Pindos Formation is mainly controlled by extensional fractures in the fault blocks striking parallel to the major faults. It is supposed that also those fault blocks that are subsided below the sea level show these high permeability features.

In contrast to the sub-parallel fractures, the normal fault planes act as hydraulic barriers. The pressure difference of $>0.5 \mathrm{MPa}$ below the Aigion fault in the AIG10 borehole suggests that the water retains in the foot wall south of the normal faults and does not migrate through the fault. Vertically oriented leakage through the clay sequence is likely but would not explain the groundwater emerging in the Gulf of Corinth, indicated by submarine springs (Soter, 1999). It is possible that water finds its way through displaced fault segments exhibiting different hydraulic conductivity. On the other hand, it is very unlikely that the entire hydraulic system communicates through those "small" leakages. Although hydraulically semipermeable or impermeable normal faults were identified in the pumping tests (Eliki Selinous test, Meganitas valley test, AIG10 pumptest) and a water pressure difference of $>100 \%$ was observed above and below normal faults (AIG10 borehole), it is very likely that even higher water flow velocity occurs mainly in deeper parts below the Olonos-Pindos Formation, in the karstic Triploitza limestones. To investigate this scenario, an additional feature was introduced in the conceptual model in Fig. VII.1 allowing water in the aquifers to flow parallel and to retain at the fault planes. In the uppermost conglomerates water flows parallel to the clay layer and then emerges as springs along the outcropping fault plane (e.g. Lion`s Wells Aigion). On the other hand, the fault plane in the conglomerates has a higher hydraulic conductivity than at the limestone-limestone contact as seen from lithological field studies. Therefore, the groundwater velocity should be higher in the upper conglomerate part above the clay aquiclude than in the platy limestones below.

The Tripolitza limestones, encountered by the AIG10 well below the Olonos-Pindos thrust nappe, are highly karstificated as known from a production test and from cores at $>770 \mathrm{~m}$ depth. It is therefore likely that fluid, retained below marine clays and at the fault, is forced downward along the fault 
plane. This flow then occurs until higher-permeability fault zone segments are reached at depth in the Tripolitza karstic limestones, which allow the flow direction to become sub-horizontal again. The flow paths in Fig. VII.1 were defined on the hydrogeological investigations and on the basis of the water pressures encountered in the AIG10 and a nearby borehole $\left(\Gamma_{1}\right)$ as well as in the investigated watersupply wells of the Selinous valley. Thus, the conceptual hydrogeological model integrates all information presently in the region. The numerical calibration of the hydrogeological conceptual model will prove the assertions.

In Summary, the conceptual model features are (Fig. VII.1):

- The phreatic water in the uppermost conglomerates flows parallel to the clay layer (1) and is partial emerging in the form of springs along outcropping normal fault planes (e.g. Eliki fault, Aigion fault, etc.). The hydrochemistry of the groundwater in the conglomerates of the Aigion fault hanging wall suggests mingling with the Gulf of Corinth water (double arrow). Receiving streams are the Selinous and/or Meganitas river systems.

- Groundwater withdrawal is very high in the upper sequence (2). Precipitation of $800 \mathrm{~mm} / \mathrm{a}$ and groundwater recharge rate is not high enough to replenish the water level to maximum in summertime but only after wintertime. In the conglomerates, the S-N-oriented flow through the fault zones and upward leakage is additionally stimulated by the intensive water withdrawal (shallow boreholes for drinking water and agricultural purposes).

- The water pressure in the limestones is higher than in the conglomerates in the whole hydraulic system (3). This suggests that upward-oriented leakages occurs through the clay sequence at the basis of the Pliocene-Pleistocene sediments, but also through the thin clay layers imbedded in the conglomerates.

- The lacustrine-lagoonal sandy clays and marine clays, which are $>100 \mathrm{~m}$ thick, separate the conglomerates above from the Olonos-Pindos Formation below forming two hydraulic systems of different hydraulic behaviour (4). Indicated from pressure measurements and hydraulic tests, flow velocity in the conglomerates must be higher than the flow below the clay aquiclude. Higher flow velocities can also be expected in deeper parts of the section, below the Olonos-Pindos Formation, where karstic conditions occur. This is indicated by production tests in the AIG10 borehole.

- Hydrochemical analysis suggest that the formation water of the Olonos-Pindos platy limestone is recharged in the mountains (5), in the hinterland of Aigion (10 km or more to the south), flows rapidly, and finally is discharged in the Gulf of Corinth (indicated by submarine springs). Because the fault zones within the Olonos-Pindos Formation obviously act as hydraulic barriers, the fluid flow is forced downward along the fault planes. This flow occurs, on the one hand, until higher-permeability fault zone segments are reached at depth, which allows the flow direction to become sub-horizontal again. On the other hand, flow is higher where it reaches the karstic Tripolitza Formation. After passing this higher permeability fault zone, the flow pattern will be again upward and oriented S-N. This is shown by the short upward arrows at the base of the cross-section. The high hydraulic resistance induced by this assumed complex flow path is supported by the water pressure difference of $0.5 \mathrm{MPa}$ between the limestones in the footwall and those of the hanging wall of the Aigion fault. 
It has to be considered that the conceptual hydrogeological model illustrates one of several possible models, but showing a good fitting with regard to the existing data. Other concepts for the model, like taking into account the lateral extension of the impervious faults in $3 \mathrm{D}$, the existence of westward oriented and vergent thrust faults (dashed lines in Fig. VII.1) or eastward dipping layers were considered and are analyzed within the plausibility and sensitivity check of the numerical models. However, due to the complexity of the tectonical structure and hydrogeology, a computerized numerical model can only be some approximation to the real natural environment. Otherwise, numerical modeling can generate a numerical image if a calibration of the model is possible. Therefore, trying to calibrate a numerical model with the input of a conceptual hydrogeological model is a way to prove.

\section{VII.3 Conversion of the conceptual model to a numerical model}

\section{VII.3.1 Finite Element subsurface FLOW and transport simulation system FEFLOW ${ }^{\circledR 1}$}

Contemporaneously with the compilation of the thermo-hydrological conceptual model, a comparison study of software presently available on the market for thermo-hydraulical numerical modeling was made. Due to the software verifications it is decided to use the software package FEFLOW ${ }^{\circledR 1}$, providing sophisticated analysis tools and stable numerical algorithms for:

- Hydraulic flow modeling (density depended if required).

- Transient or steady-state flow.

- Saturated and unsaturated flow.

- Multiple free surfaces (perched water table).

- Mass or heat transport.

\footnotetext{
1 FEFLOW $^{\circledR}$ Interactive Graphic-based Finite Element Simulation System for Subsurface Flow and Transport Processes; Copyright (C) 1979-2005 by WASY Ltd., Berlin, Germany; Version 5.204 (3D+2D) (PROF. H.-J. DIERSCH, November 2005)
} 
The components for building a finite element model, simulation runs, and result visualization in FEFLOW $^{\circledR}$ are given by comprehensive selections of graphical tools for building finite element meshes, assigning property zones and setting boundary conditions. After creating the outer boundary of the area to model and after defining polygons for the generation of a finite element mesh the specifications of all model attributes are completed in the Feflow Problem Classifier Menu. It allows to define the model physics, specify problem classes, control data and time characteristics. After setting the model design features due to the conceptual hydrogeological model and other investigations in general it has to decide about the main model classification available in Feflow: Model Type, Problem Class, Flow and Heat or Mass Transport. All detailed features about Feflow are given in Diersch, 2005. Numerical modeling of groundwater flow and transport processes and especially numerical flow modeling are well established and widely applied. The concepts, background and theory will not be discussed in the context of this thesis and only a rough reflection is given in the following but have been described extensively in the literature (e.g. Anderson \& Woessner, 1992, Diersch, 2005, Kinzelbach \& Rausch, 1995, Kolditz, 1997, Rausch et al., 2005, Witthüser, 2002, and many others).

In general FEFLOW ${ }^{\circledR}$ provides numerical modeling solutions to describe movement of groundwater or heat-flow for porous aquifers or aquitards. A 3-D groundwater body in a assumed saturated porous medium can be described as a two-phase system with fluid-solid interaction. Then the Darcy velocity in a three dimensional system can be described through:

$$
\vec{v}=K_{f} \vec{\nabla} h \quad\left(\mathrm{~K}_{\mathrm{f}}: \text { hydraulic conductivity }\right)
$$

and the piezometric or hydraulic head h: $\quad \vec{\nabla} h=\frac{\partial h}{\partial x}+\frac{\partial h}{\partial y}+\frac{\partial h}{\partial z}$

In this case the considered 2-D vertical problem with steady-state flow conditions is leading to a simplification by the Laplace equation for the analytically solution of the partial differential equation and the estimation of hydraulic heads or rate of flow. The basic formula are founded on the constitutive equations of Darcy's law and the principle of mass conservation and energy conservation:

$$
\frac{\partial^{2} h}{\partial x^{2}}+\frac{\partial^{2} h}{\partial z^{2}}=0
$$

The steady-state flow conditions are used as an approximation and means that the boundaries has "recharging" boundary conditions. In a simulation of a steady-state flow time-step control parameters are not applicable and only one iteration is performed for the flow. Discrete elements for joints, fractures and faults can be implemented in the model whereas the groundwater flow equations for fractured or karstic aquifers can not be considered in FEFLOW ${ }^{\circledR}$. Flow and heat material parameters attached on the fractured platy limestones or karstic Tripolitza limestones below deserve therefore a very close attention due to the plausibility and sensitivity. However, assuming steady-state flow conditions together with a well defined conceptual model and a plausible definition of model boundaries FEFLOW ${ }^{\circledR}$ is fulfilling the demands of this study successfully. 
In general numerical calculations starts with defined starting conditions (e.g. hydraulic head, conductivities, temperature, etc.). After quantifying the model domain and the definition of material parameters it is therefore necessary to set the boundary conditions. In FEFLOW ${ }^{\circledR}$ the following boundary conditions for flow and transport processes can be considered (a detailed description of the different types is given in the Reference Manual by Diersch, 2005):

- 1 'st kind boundary condition (Dirichlet type):

for flow boundaries:

Head - a fixed potential is set on a node; hydraulic head [m]

for transport boundaries:

Mass or Heat - contaminant or fixed temperature $\left[{ }^{\circ} \mathrm{C}\right]$

- $\quad 2$ nd kind boundary condition (Neumann type) :

for flow boundaries:

Flux - assigns a flux to a node $[\mathrm{m} / \mathrm{d}],\left[\mathrm{m}^{2} / \mathrm{d}\right]$

for transport boundaries:

Heat flow - inflow or outflow of thermal energy $\left[\mathrm{J} / \mathrm{m}^{2} / \mathrm{d}\right]$

- $\quad 3{ }^{`}$ rd kind boundary condition (Cauchy type):

for flow boundaries:

Transfer -defines a reference of hydraulic head outside the model domain (e.g. river, lake) [m]

for transport boundaries:

Transfer - inflow or outflow through a leaching layer $\left[{ }^{\circ} \mathrm{C}\right]$

- 4 th kind boundary condition (Well boundary)

for flow boundaries:

Well - describes the injection or water catchment $\left[\mathrm{m}^{3} / \mathrm{d}\right]$

for transport boundaries:

Well - single source for thermal energy $[\mathrm{J} / \mathrm{d}]$

- kind of no definition for the boundary conditions:

in this case the model boundary react as a closed system; no energy is able to cross 


\section{VII.3.2 Construction of the numerical model}

The 2-D cross section for the thermo-hydraulic model is extracted out of the overall $22 \mathrm{~km} \mathrm{~N}$-S-cross section of the Aigion area (Fig. VII.3a, (extension and location see Fig. IV.27 and Fig. IV.28)). Similar to the $14 \mathrm{~km}$ conceptual model it is decided to evaluate the conditions not in a very outranged regional area. Instead, due to the most amount of data available at depth, it is concentrated on the Aigion fault AIG10 borehole in its center, as described from the conceptual model. Whereas the conceptual model ranges from Trapeza Mt. to the Gulf in SSW-NNW direction other concepts for the model, like taking into account the lateral extension of the impervious faults in $3 \mathrm{D}$ or the existence of a continuous thick impervious clay layer on the ground of the Corinth Gulf resulting in the changing from the SSW-NNW direction to a S-N oriented cross section passing through the Selinous river test site EQ1 and the AIG10 borehole (Fig. VII.3a (dashed box) and Fig. VII.3b).

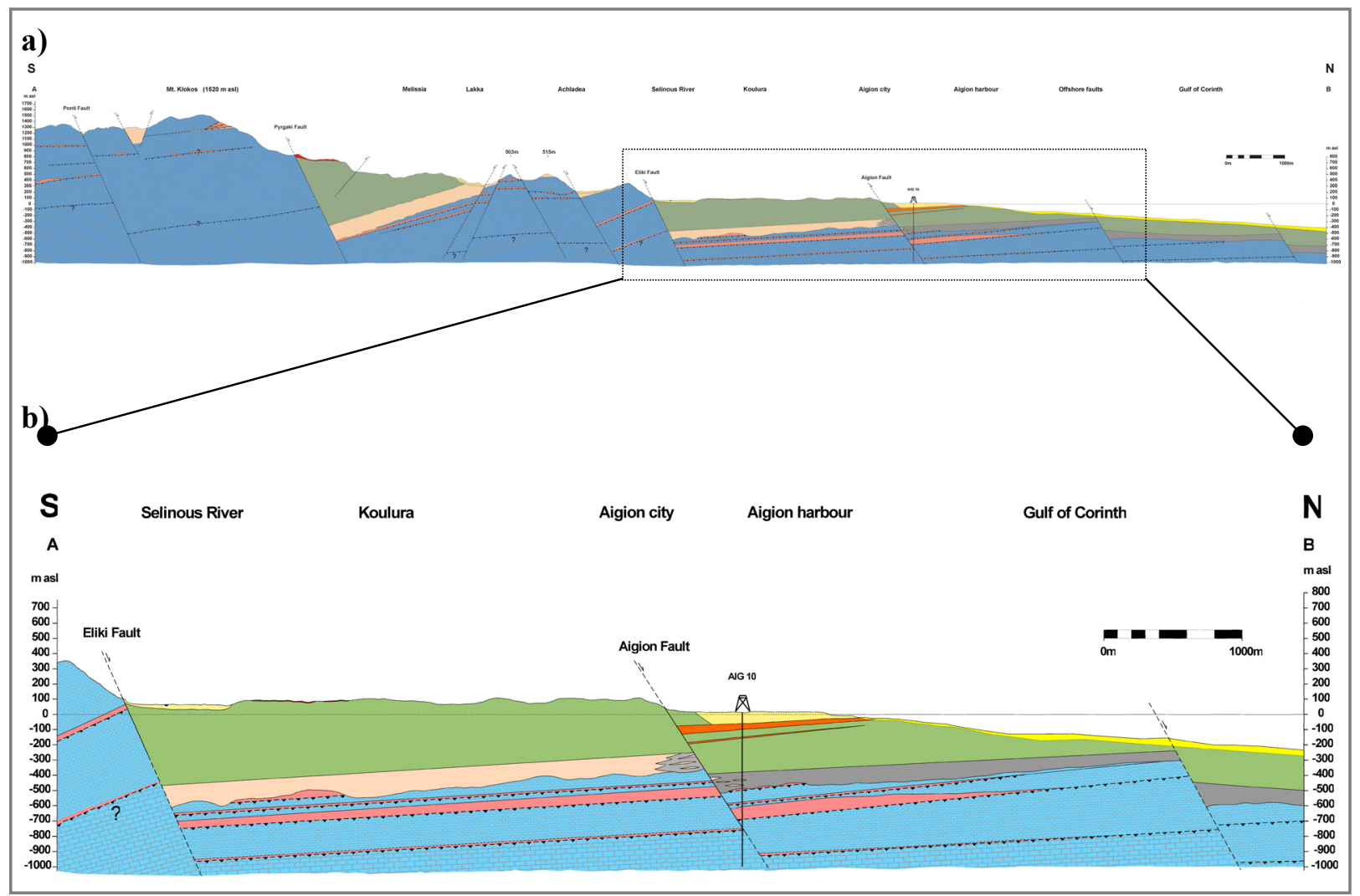

Fig. VII.3: Schematic $22 \mathrm{~km} \mathrm{N-S} \mathrm{cross} \mathrm{section} \mathrm{served} \mathrm{as} \mathrm{a} \mathrm{basis} \mathrm{for} \mathrm{the} \mathrm{numerical} \mathrm{model} \mathrm{domain.} \mathrm{a):} \mathrm{the} \mathrm{dashed}$ rectangle highlights the extracted 2-D model domain b) with the centred Aigion normal fault, the Eliki fault in the South and offshore faults in the Gulf of Corinth graben in the North (legend and details of the cross section see chapter IV, Fig. IV.28). 
The model classification (problem class) and general problem definition used is a 2-dimension problem for saturated flow and mass transport under steady state conditions. Before starting a coupled heat and flow model the model needs to calibrated for the proposed groundwater flow. The base for each numerical model is a well-generated finite element mesh. At first, the defined 2-D vertical model domain has to be divided into the relevant sections in form of so-called supermeshes or superelements. The supermesh is based on the superelement borders which represents the hydrogeological and tectonical-geological boundaries from the hydrogeological conceptual model. These elements are the basis for generating the finite element mesh. The mesh editor available in FEFLOW ${ }^{\circledR}$ is a CADoriented tool to enter the geometric data necessary for the numerical model. During a simulation, results are computed on each node of the finite element mesh and interpolated within the finite elements. The denser the mesh the better the numerical accuracy, and the higher the computational effort (Diersch, 2005). The mesh generated for the 2-D vertical problem is shown in Fig. VII.4. The 2-D cross section has a (net-) length of $7625 \mathrm{~m}$ with a vertical exaggeration of 1:1. The 3-noded triangles with 44807 mesh elements and 22922 mesh nodes are based on the TMesh (Delaunay) generator which allows to define local variations of mesh density. This is chosen to refine the superelement borders (lithological boundaries) as well as the Aigion fault zone and to require more computational effort at the borders and fault zone.

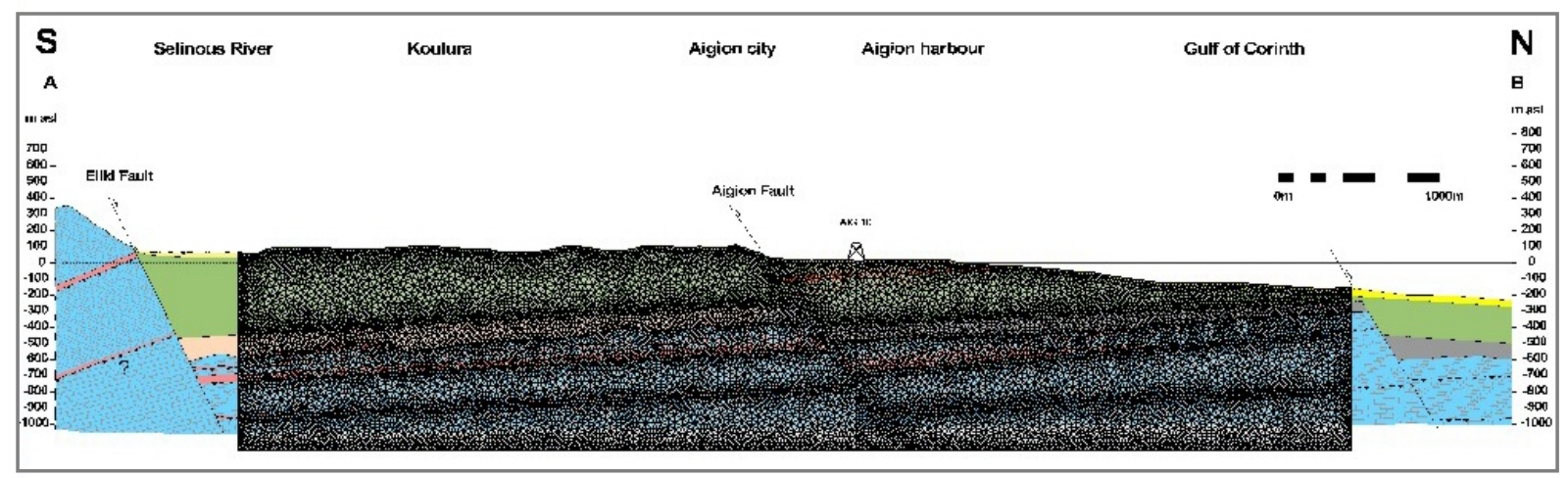

Fig. VII.4: TMesh-Delaunay-generated mesh for the 2-D vertical problem which allows to define local variations of mesh density. The mesh length and horizontal extend is $7625 \mathrm{~m}$ with a vertical exaggeration of 1:1. The 3noded triangles offer 44807 mesh elements and 22922 mesh nodes where results are computed on each node of the finite element mesh and interpolated within the finite elements.

The Supermesh is used for the attribution of the hydraulic and thermal properties and model boundary conditions and consists of outer and inner areas (Fig. VII.5). 12 areas are assigned to the lithological units $\left(\mathrm{Kf}_{1}-\mathrm{Kf}_{12}\right)$. These areas can be attributed with hydraulic conductivities (for hydraulic flow model), thermal conductivities (for heat flow model) or both (coupled thermo-hydraulic model). This approach has the advantage that one can shutdown one of each property and can study the influence to the other. 
Special attention is given to the Aigion fault zone. As mentioned before, the net is refined at the fault zone to integrate more details of the hydraulic behavior of the fault. On the one hand, the hydraulic fault behavior is completely different than of the lithological units and the fault behavior is different in-between the fault zone itself. Therefore, it must be allowed to consider different fault contact properties (e.g. limestone-limestone contact, limestone-marine clay contact, conglomerate contact, etc.). For this reason, the fault zone in the supermesh is segmented in 14 areas $\left(f_{1}-f_{14}\right.$ in Fig. VII.5), in which different hydraulic and thermal properties are assigned. Additionally, the fault zone has to be segmented in an left and right zone because the fault can not be described by a simple line. Furthermore, numerical modeling is only possible between two boundaries. Although this leads to a falsification in horizontal scale, this constraint has to be accepted, otherwise a thermo-hydraulic process along the fault zone would not be possible.

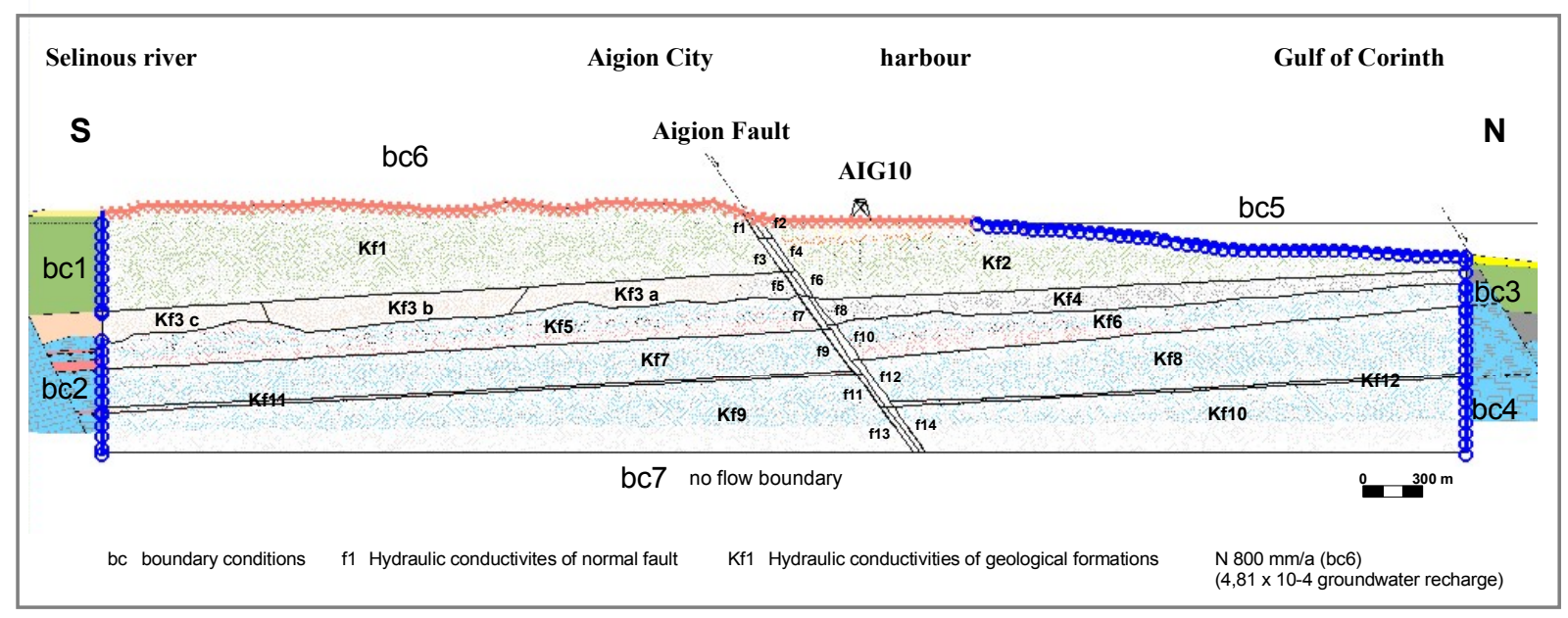

Fig. VII.5: Supermesh generated for the 2-D vertical problem. The supermesh is used for the attribution of hydraulic and thermal properties and model boundary conditions (bc1-8). 12 areas are assigned to the lithological units $\mathrm{Kf}_{1}-\mathrm{Kf}_{12}$ whereas the fault zone is segmented in 14 areas $\mathrm{f}_{1}-\mathrm{f}_{14}$ (more details are given in the text and in the attribute tables VII.8-10).

The model boundaries and model boundary conditions (bc) reflect the hydrogeological conceptual model as well as the results of first model runs, plausibility checks and sensitivity checks. The final solution is displayed in Fig. VII.5. The model periphery is selected in 7 sections bcl - bc7. The boundary conditions of hydraulic and/or thermal properties can be assigned to each section. bc1 describes the properties for the upper southern boundary conditions consisting of conglomerates as well as Quaternary deposits (hydraulic head, annual average subsurface temperature influence) whereas bc2 is for the lower southern part Olonos-Pindos Formation and Tripolitza (hydraulic head, annual average subsurface temperature influence). The marine-lagoonal deposits between bc1 and bc2 represent no-flow conditions. Thus all (input-) influences of the hinterland and southern Eliki fault are considered here. 
Knowing that the hydraulic system is developed from south to north (left to right in Fig. VII.5), bc3, bc 4 and bc5 are chosen to be the open model system representing the northern model boundary at depth bc3,4 and the offshore seafloor bc5. That means that here starting conditions of hydraulic head is set to zero and depend on the values attached to bc1 and bc2. In this manner, water from bc1 and bc2 then flows to bc3-5 passing all lithological units $\left(\mathrm{Kf}_{1}-\mathrm{Kf}_{12}\right)$ and the centered normal fault plane contacts $\left(f_{1}-f_{14}\right)$.

bc6 represents the onshore surface plane. Influence of precipitation and groundwater recharge from this plane and the annual average surface or air temperature are considered here. bc7 represents the lowermost model boundary at $1155 \mathrm{~m}$ depth, to which the hydraulic and thermal conditions from below the model depth can be attached. Finally, bc8 is attached to a surface net node at the outcropping Aigion fault plane (between $\mathrm{f}_{1}$ and $\mathrm{f}_{2}$ ) representing the Lion's Well at the Aigion harbor where well characteristic is known.

To observe the model run, FEFLOW ${ }^{\circledR}$ displays curves for hydraulic head and heat flow or temperature in wells and flux boundaries during simulation. In addition the software package provides the possibility to halt and view results on line sections (e.g. AIG10 borehole). This was very helpful for the calibration and reference data information as it allowed to observe the results in "quick-spots" through observation points (OP). The observation points are chosen by optimal positions to have reference points in all relevant sequences. Therefore 10 points were set on net nodes representing surface level and seawater level (OP1, OP2), depth of pumping tests (OP3, OP7), above and below the fault plane (OP7, OP8), total borehole depth (OP9), and lowest model domain (OP10). Here the modeled results can compared to the values measured in the well-logs (Tab. VII.1). The observation points therefore are most important for a quick look on the results, the plausibility and/or sensibility check and for the calibration of the hydraulic resp. thermal model.

Tab. VII.1: Distribution of observation points OP1-10 along the AIG10 borehole and model profile.

\begin{tabular}{l|l|l}
\hline observation point OP & depth [m] & representative for \\
\hline 1 & $+12,42$ & surface level \\
2 & $+00,07$ & 0 ; seawater level \\
3 & $-215,88$ & $215 \mathrm{~m} ;$ PumpTest AIG10C $(211,8-256,4 \mathrm{~m})$ \\
4 & $-453,82$ & $450 \mathrm{~m}$; marine clay \\
5 & $-540,71$ & $540 \mathrm{~m} ;$ Pindos limestones with radiolarite intercalations \\
6 & $-635,62$ & $635 \mathrm{~m}$; radiolarites \\
7 & $-721,17$ & $720 \mathrm{~m}$; PumpTest AIG10L (708,8 - 744,8 m) \\
8 & $-781,33$ & $780 \mathrm{~m}$; below Aigio fault; Tripolitza; \\
9 & $-1001,89$ & $1001 \mathrm{~m}$; Total Depth \\
10 & $-1156,95$ & $1155 \mathrm{~m}$; total depth of model \\
\hline
\end{tabular}




\section{VII.4 Hydraulic calibration and flow model near faults}

\section{VII.4.1 General assumptions}

Before the preparation of a coupled heat and flow model it is started with the calibration of the proposed groundwater flow, "switching on" temperature and heat flow afterwards. For this it is attempt to model the hydraulic behavior of the Aigion normal fault and the simulation of the hydraulic flow of the lithological units. Reflecting all features of the designed conceptual hydrogeological model and all results from investigations the hydraulic parameters as permeability coefficients $\left(\mathrm{K}_{\mathrm{f}}\right)$, porosity, boundary conditions or rate of flow were implemented onto the Superelements (Fig. VII.5).

The following assumptions are equal for all problem attributes of the generated model: the general type of simulation problem is for saturated media (groundwater) with (a) "flow only" for the hydraulic flow model and (b) "flow and heat transport" for the coupled thermo-hydraulic model. The flow-only problem is chosen with steady state conditions which means steady flow (a) resp. steady flow / steady transport (b) in combination with confined and saturated aquifer conditions. Due to the vertical projection of the 2-D cross-section the gravity orientation and the direction of the gravity vector is the negative y-axis. By simulating steady-state conditions we can ignore time control parameters and the default values of FEFLOW ${ }^{\circledR}$ are fully implicit with constant time steps (time step $=1$; length of time step $=0.001 \mathrm{~d})$.

\section{VII.4.2 Plausibility-, Sensibility-Check and starting conditions for flow}

Tab. VII.2 displays the summary of values and starting conditions for the calibration of the hydraulic flow model. It is noticed here that it was possible to generate three different calibrated hydraulic models $[\mathrm{A}]-[\mathrm{C}]$. To control the hydraulic behavior in the system three possibilities are implemented in the model:

- hydraulic conductivity parameters $\left(\mathrm{k}_{\mathrm{f}}\right.$-values in $\left.\mathrm{m} / \mathrm{s}\right)$ attached to the supermesh elements controls the hydraulic conductivity of the lithological units $\mathrm{Kf}_{1}-\mathrm{Kf}_{12}$.

- $\quad$ assumed (but analyzed on plausibility and sensitivity) hydraulic conductivity parameters $\left(\mathrm{k}_{\mathrm{f}}-\right.$ values in $\mathrm{m} / \mathrm{s}$ ) attached to the supermesh elements $\mathrm{f}_{1}-\mathrm{f}_{14}$ to control the hydraulic behavior of the normal fault plane.

- $\quad$ setting of boundary conditions bc $1-b c 8$ 


\section{VII.4.2.1 Hydraulic conductivity attributed to the lithological elements}

The starting conditions for the hydraulic conductivity parameters $\left(\mathrm{k}_{\mathrm{f}}\right.$-values in $\left.\mathrm{m} / \mathrm{s}\right)$ of $\mathrm{Kf}_{1}-\mathrm{Kf}_{4}$ and $\mathrm{Kf}_{7}-\mathrm{Kf}_{8}$ are derived from pumping tests and $\mathrm{Kf}_{10}-\mathrm{Kf}_{11}$ from the production test in AIG10. From the pumping test in the conglomerates an average hydraulic conductivity value of $2,43 \times 10^{-5} \mathrm{~m} / \mathrm{s}$ is attached to the upper sequence of Quaternary sediments and the conglomerates $\left(\mathrm{Kf}_{1}\right.$ and $\left.\mathrm{Kf}_{2}\right) .3,18 \mathrm{x}$ $10^{-5} \mathrm{~m} / \mathrm{s}$ is approximated from the Meganitas pumping test results for the marine clay in the hangingwall $\mathrm{Kf}_{4}$ and the adjacent marine to lagoonal units of $\mathrm{Kf}_{3 \mathrm{a}-\mathrm{c}}$. In the very inhomogeneous and lithological complex sequence from 496-698 $\mathrm{m}$ a less hydraulic permeability is assumed in relation to the pumping test results from the platy limestones below. Whereas the average value from AIG10L is $1,08 \times 10^{-7} \mathrm{~m} / \mathrm{s}$ and is attached to $\mathrm{Kf}_{7}$ and $\mathrm{Kf}_{8}$ less values of $9 \times 10^{-8} \mathrm{~m} / \mathrm{s}$ is attached to $\mathrm{Kf}_{5}$ and $\mathrm{Kf}_{6}$ for starting conditions. The artesian production test in the interval $708-1001 \mathrm{~m}$ showing karstic conditions and a fluid pressure of $>1 \mathrm{MPa}$ with natural flow of $1.5 \times 10^{-2} \mathrm{~m}^{3} / \mathrm{s}$ resulted in a transmissivity of $2-3 \times 10^{-4} \mathrm{~m}^{2} / \mathrm{s}$. For the lowest karstic limestone sequence therefore a average hydraulic conductivity of $0,8 \times 10^{-6} \mathrm{~m} / \mathrm{s}$ is attached to $\mathrm{Kf}_{9}$ and $\mathrm{Kf}_{10}$. Finally, to the thrust fault zone between the Olonos-Pindos formation and the Tripolitza formation a experience value from literature found for typical limestone cataclasits is attached. The value of $5 \times 10^{-8} \mathrm{~m} / \mathrm{s}$ fits very good in the model and is in-between the value of the platy limestones above and the Tripolitza limestones below and is attached to $\mathrm{Kf}_{12}$ and $\mathrm{Kf}_{13}$.

\section{VII.4.2.2 Hydraulic conductivity attributed to the fault elements}

No detailed hydraulic analysis is available for the fault plane but macroscopic analysis on outcrops, surface samples, and AIG10 core samples give evidence about the hydraulic conductivity. Furthermore the semipermeable hydraulic fault behavior is known from hydraulic tests. At the fault contact between conglomerates and conglomerates $\left(f_{1}, f_{2}, f_{3}, f_{4}\right.$ and $\left.f_{6}\right)$ in the graben fill less permeability than resulted from the pumping test AIG10C is assumed, therefore starting conditions in the model configuration are set to $\mathrm{k}_{\mathrm{f}}=1,4 \times 10^{-5} \mathrm{~m} / \mathrm{s}$. $\mathrm{f}_{5}$ and $\mathrm{f}_{8}$ (marine clay fault contact)are assumed to be similar with marine clay $\left(\mathrm{Kf}_{3 \mathrm{a}}, \mathrm{Kf}_{4}\right)$ but is reduced due to fault plane movement to $8 \times 10^{-8} \mathrm{~m} / \mathrm{s}$. $\mathrm{f}_{7}$ and $f_{10}$ are representing the fault contact of the radiolarite-limestone sequence and the hydraulic conductivity of $7 \times 10^{-5} \mathrm{~m} / \mathrm{s}$ is chosen to be between $\mathrm{f}_{5}$ (clay) and $\mathrm{Kf}_{5}$ (limestone/radiolarite).

The similar approach is applied to $f_{9}$ and $f_{12}$. Both are fault contacts of platy limestones and the radiolarite-limestone sequence. The hydraulic conductivity must be in-between these two, which means $>$ f5 (clay) but $<$ Kf7 (platy limestones AIG10L). The $\mathrm{k}_{\mathrm{f}}$-value of $9 \times 10^{-4} \mathrm{~m} / \mathrm{s}$ provides a intermediate value and furthermore it is plausible for this formation contact. Following this approach for $\mathrm{f}_{11}, \mathrm{f}_{13}$ and $\mathrm{f}_{14}$, representing Tripolitza limestone fault contact, the hydraulic conductivity must be between the platy limestones and the unfaulted Tripolitza limestones. Therefore $\mathrm{k}_{\mathrm{f}}$-values of $5 \times 10^{-7}$ $\mathrm{m} / \mathrm{s}$ are set to this contacts. 


\section{VII.4.2.3 Hydraulic boundary conditions for flow}

- Fixed hydraulic head (bc1, bc2, bc3, bc4, bc5):

The southern model boundary (Fig. VII.5) is fixed by a constant hydraulic head in the conglomerate sequence (bc1) and limestone sequence below (bc2) with a no-flow boundary of the marine-lagoonal clay sequence in-between. If we assume a hydraulic head at the left boundary (South) and less hydraulic head at the right boundary (North) we will produce a hydraulic potential which will let the inflowing water move from left to right (respectively South to North) through all geological formations and the centred fault plane. The conglomerates on the top are on the one hand influenced by precipitation and on the other hand by the groundwater flow of the hinterland and southern Eliki fault. As mentioned before it is assumed that we have confined, saturated and artesian conditions (confirmed by artesian wells and pumping tests) and so an plausible average value of $10 \mathrm{~m}$ hydraulic head is attached to bc1. The boundary bc2, present at the hard rock below the rift sediments is not influenced by surface conditions. As we have seen in further discussions the lower part has strong hydraulic contact to the hinterland with high relief. $130 \mathrm{~m}$ constant hydraulic head is attached to the southern boundary bc2 (respectively lower left model boundary). To produce a hydraulic potential the right boundaries are set to zero $(b c 3=b c 4=b c 5=0)$. The variation and control of the hydraulic parameters at the supermesh elements will give evidence of flow velocity and will prove the assumptions of $\mathrm{bc} 1-\mathrm{bc} 5$.

- Flux (bc6):

bc6 is the input of hydraulic flux into the model domain and represents the amount of groundwater recharge but only related to the onshore model surface. The width of the 2-D cross-section in FEFLOW $^{\circledR}$ is not infinitesimal or even zero and is standardised to a slitting width of $1 \mathrm{~m}$. The cut-out length of the net related to the onshore part of the cross section is calculated to $4411.8 \mathrm{~m}$. For the implementation of the input flux at bc6 the following calculations are derived:

considered length of the cut-out onshore part

average precipitation per year for Achaia/Greece :

considered catchment volume $\mathrm{V}_{\mathrm{c}}$ related to $800 \mathrm{~mm}$ precipitation, standardised: $\mathrm{V}_{\mathrm{c}}=4411.8 \mathrm{~m} \times 1 \mathrm{~m} \times 0.8 \mathrm{~m}=3529.44 \mathrm{~m}^{3} / \mathrm{a}=$

groundwater recharge less surface run-off (15\%), Evapotranspiration (63\%) in Achaia/Greece after Nikas, 2001: $22 \%$ of $\mathrm{V}_{\mathrm{c}}=2.12 \mathrm{~m}^{3} / \mathrm{d}$, standardised for the model domain of net-length $\mathrm{x} 1 \mathrm{~m}$
$4411.8 \mathrm{~m}$.

$800 \mathrm{~mm} / \mathrm{a}$

$9.67 \mathrm{~m}^{3} / \mathrm{d}$

$2.12 \mathrm{~m}^{2} / \mathrm{d}$

The inflow of precipitation per node (bc6) into the model can now be calculated by the relation of the groundwater recharge in $m$ per day to the cut-out onshore length:

bc6 $=2.12 \mathrm{~m}^{2} / \mathrm{d}$ divided by $4411.8 \mathrm{~m}$

$\Rightarrow \quad$ bc $6=4.18 \times 10^{-4} \mathrm{~m} / \mathrm{d}$ per node 
- no flow boundary (bc7):

For the hydraulic flow model the lower boundary has no setting. In doing this the model boundary is occupied and no energy is able to cross. The lower part is therefore independent from hydraulic influences at depth and will be treated as impervious to flow entering or leaving the model domain.

\section{VII.4.3 Hydraulic flow calibration}

The basic principle of the hydraulic calibration was the modification and observation of the attached starting conditions and boundary conditions (Tab. VII.2). As mentioned before the hydraulic conductivities of lithological units derived from hydraulic tests should vary only in a plausible range of values whereas the fault segments are allowed to vary a bit more. The similar procedure is applied to the starting conditions of the boundaries which are resulting from the conceptual model. These as well are allowed to vary only in plausible ranges of values. Primarily the monitoring of the observation points 1-10 along the AIG10 borehole profile is of importance. Because they are attached at spots with well known information they provided a good tool for studying if the parameters keep in plausible conditions as there are hydraulic conductivity, hydraulic flux or pressure difference.

During numerical simulation all observation points were observed and the most important calibration factor was the hydraulic head set above and below the Aigion normal fault. All given parameters are varied until the computed pressure (resp. hydraulic head) is relatively equal to the known values and the difference of 5 bar is recorded in the observation points above and below the fault plane. For the observation points OP7 (720 m bsl) $50 \mathrm{~m}$ and OP8 (780 m bsl) $100 \mathrm{~m}$ hydraulic head has to be attained. A self-criteria is given where the range of values at OP7 and 8 are allowed to vary only in a range of $+/-5 \%$.

The analysis of sensitivity has shown that the variation of the hydraulic conductivity of the lithological units has influence to the hydraulic behavior in the system. But the facility of variation of the hydraulic conductivity parameters attached to the lithology are not very high if the values were in between plausible ranges so that here the calibration confirms the hydraulic test results and vice versa (Tab. VII.2). Stronger deviations can only seen in Version [B] in which the platy limestones are considered to be karstic through the attachment of higher permeability to this formation.

The calibration of the pressure difference at the Aigion fault however was not possible with lithological conductivity parameters only. The most effective tool to retain the groundwater at the fault plane and to build up the pressure difference was the assignment of hydraulic conductivities to the fault segments. The simulation runs has shown that the pressure difference at the fault contact is only possible to generate when the hydraulic conductivity at the conglomerate-conglomerate contact is higher than at the fault contacts in the formations below. It is shown that the empirical values for the conglomerate-conglomerate contact fits very well with the numerical model $\left(f_{1}-f_{3}\right)$ whereas the hydraulic conductivities for the fault contact interaction between marine clay, limestones, radiolarite, etc. below had to correct to much more impervious conditions than assumed $\left(f_{4}-f_{14}\right)$. Finally the numerical calibration of the model resulted in fault conductivities of $k_{\mathrm{f}}=10^{-5} \mathrm{~m} / \mathrm{s}$ for the 
conglomerate-conglomerate contact and down to $10^{-10} \mathrm{~m} / \mathrm{s}$ for the contacts below the impermeable marine clay sediments (Tab. VII.2).

Tab. VII.2: Summary of values and conditions for the calibrated hydraulic models [A], [B], \& [C].

\begin{tabular}{|c|c|c|c|c|c|c|}
\hline Supermesh & starting condition values & origin / remarks & Supermesh & [A] & [B] & [C] \\
\hline $\mathrm{Kf1}[\mathrm{m} / \mathrm{s}]$ & $2,43 \times 10^{-5}$ & average value of AIG10C; & Kf1 & $2,30 \mathrm{E}-05$ & $1,00 \mathrm{E}-04$ & $2,30 \mathrm{E}-05$ \\
\hline Kf2 [m/s] & $2,43 \times 10^{-5}$ & average value of AIG10C; & Kf2 & $2,30 \mathrm{E}-05$ & $1,00 \mathrm{E}-04$ & $2,30 \mathrm{E}-05$ \\
\hline $\mathbf{K f 3 a}[\mathrm{m} / \mathrm{s}]$ & $3,18 \times 10^{-8}$ & approx. Meganitas test PB3 & Kf3a & $1,00 \mathrm{E}-09$ & $1,00 \mathrm{E}-09$ & $1,00 \mathrm{E}-09$ \\
\hline Kf3b $[\mathrm{m} / \mathrm{s}]$ & $3,18 \times 10^{-8}$ & approx. Meganitas test PB3 & Kf3b & $5,00 \mathrm{E}-09$ & 5,00E-09 & $5,00 \mathrm{E}-09$ \\
\hline Kf3c [m/s] & $3,18 \times 10^{-8}$ & approx. Meganitas test PB3 & Kf3c & $9,00 \mathrm{E}-09$ & $9,00 \mathrm{E}-09$ & $9,00 \mathrm{E}-09$ \\
\hline Kf4 [m/s] & $3,18 \times 10^{-8}$ & approx. Meganitas test PB3 & Kf4 & $1,00 \mathrm{E}-09$ & $1,00 \mathrm{E}-09$ & $1,00 \mathrm{E}-09$ \\
\hline Kf5 [m/s] & $9,00 \times 10^{-8}$ & less permeability than Kf7/8 (AIG10L) & Kf5 & $1,00 \mathrm{E}-07$ & $1,00 \mathrm{E}-03$ & $1,00 \mathrm{E}-07$ \\
\hline Kf6 [m/s] & $9,00 \times 10^{-8}$ & less permeability than Kf7/8 (AIG10L) & Kf6 & $1,00 \mathrm{E}-07$ & $1,00 \mathrm{E}-03$ & $1,00 \mathrm{E}-07$ \\
\hline Kf7 [m/s] & $1,08 \times 10^{-7}$ & average value of AIG10L & Kf7 & $1,08 \mathrm{E}-06$ & $1,00 \mathrm{E}-02$ & $1,08 \mathrm{E}-06$ \\
\hline Kf8 [m/s] & $1,08 \times 10^{-7}$ & average value of AIG10L & Kf8 & 1,08E-06 & $1,00 \mathrm{E}-02$ & 1,08E-06 \\
\hline Kf10 $[\mathrm{m} / \mathrm{s}]$ & $0,8 \times 10^{-6}$ & average value of AIG production test & Kf9 & $9,00 \mathrm{E}-06$ & $9,00 \mathrm{E}-02$ & $9,00 \mathrm{E}-06$ \\
\hline Kf11 [m/s] & $0,8 \times 10^{-6}$ & average value of AIG production test & Kf10 & $9,00 \mathrm{E}-06$ & $9,00 \mathrm{E}-02$ & $9,00 \mathrm{E}-06$ \\
\hline Kf12 [m/s] & $5,00 \times 10^{-8}$ & thrust fault Pindos/Tripolitza; experience value cataclasit & Kf11 & $5,00 \mathrm{E}-08$ & $5,00 \mathrm{E}-04$ & $5,00 \mathrm{E}-08$ \\
\hline $\mathrm{Kf13}[\mathrm{m} / \mathrm{s}]$ & $5,00 \times 10^{-8}$ & thrust fault Pindos/Tripolitza; experience value cataclasit & Kf12 & $5,00 \mathrm{E}-08$ & $5,00 \mathrm{E}-04$ & $5,00 \mathrm{E}-08$ \\
\hline $\mathrm{f1}[\mathrm{m} / \mathrm{s}]$ & $1,40 \times 10^{-5}$ & less permeability than conglomerates & f1 & $1,15 \mathrm{E}-05$ & $1,15 \mathrm{E}-05$ & $1,15 \mathrm{E}-05$ \\
\hline f2 $[\mathrm{m} / \mathrm{s}]$ & $1,40 \times 10^{-5}$ & from AIG10C; & f2 & $1,15 \mathrm{E}-05$ & $1,15 \mathrm{E}-05$ & $1,15 \mathrm{E}-05$ \\
\hline f3 $[\mathrm{m} / \mathrm{s}]$ & $1,40 \times 10^{-5}$ & & f3 & 1,15E-05 & 1,15E-05 & $1,15 \mathrm{E}-05$ \\
\hline $\mathrm{f} 4[\mathrm{~m} / \mathrm{s}]$ & $1,40 \times 10^{-5}$ & (limnic-fluviatile clay in conglomerates) & f4 & $9,00 \mathrm{E}-06$ & $9,00 \mathrm{E}-06$ & $9,00 \mathrm{E}-06$ \\
\hline f5 [m/s] & $8,00 \times 10^{-8}$ & marine clay & f5 & $9,00 \mathrm{E}-09$ & $9,00 \mathrm{E}-09$ & $1,00 \mathrm{E}-10$ \\
\hline f6 [m/s] & $1,40 \times 10^{-5}$ & f1 conglomerates & f6 & $3,00 \mathrm{E}-06$ & $3,00 \mathrm{E}-06$ & $1,00 \mathrm{E}-10$ \\
\hline $\mathrm{f} 7[\mathrm{~m} / \mathrm{s}]$ & $7,00 \times 10^{-5}$ & between f5 (clay) Kf5 (limest+rad) & f7 & $5,00 \mathrm{E}-09$ & $5,00 \mathrm{E}-09$ & $1,00 \mathrm{E}-09$ \\
\hline f8 $[\mathrm{m} / \mathrm{s}]$ & $8,00 \times 10^{-8}$ & f5 marine clay & f8 & $9,00 \mathrm{E}-09$ & $9,00 \mathrm{E}-09$ & $1,00 \mathrm{E}-10$ \\
\hline f9 $[\mathrm{m} / \mathrm{s}]$ & $9,00 \times 10^{-4}$ & $>$ as f5 (clay) < as Kf7 (limestones) & f9 & $1,00 \mathrm{E}-08$ & $1,00 \mathrm{E}-08$ & $7,00 \mathrm{E}-10$ \\
\hline $\mathrm{f10}[\mathrm{m} / \mathrm{s}]$ & $7,00 \times 10^{-5}$ & f7 between f5 (clay) Kf5 (limest+rad) & f10 & $5,00 \mathrm{E}-09$ & $5,00 \mathrm{E}-09$ & 1,00E-09 \\
\hline f11 [m/s] & $5,00 \times 10^{-7}$ & between f9 (limest) and Kf9 (Tripo) & f11 & $7,00 \mathrm{E}-08$ & $7,00 \mathrm{E}-09$ & $3,00 \mathrm{E}-09$ \\
\hline $\mathrm{f12}[\mathrm{m} / \mathrm{s}]$ & $9,00 \times 10^{-4}$ & f9 > as f5 (clay) < as Kf7 (limestones) & f12 & $8,00 \mathrm{E}-09$ & $7,00 \mathrm{E}-09$ & $1,00 \mathrm{E}-10$ \\
\hline f13 [m/s] & $5,00 \times 10^{-7}$ & f11 between f9 (limest) and Kf9 (Tripo) & f13 & $7,00 \mathrm{E}-08$ & $8,00 \mathrm{E}-10$ & $9,00 \mathrm{E}-09$ \\
\hline $\mathrm{f} 14[\mathrm{~m} / \mathrm{s}]$ & $5,00 \times 10^{-7}$ & f11 between f9 (limest) and Kf9 (Tripo) & f14 & $1,00 \mathrm{E}-08$ & $1,00 \mathrm{E}-08$ & $5,00 \mathrm{E}-09$ \\
\hline bc1 $[\mathrm{m}]$ & $10 \mathrm{~m}$ constant & hydr. head; conglomerates (clay no flow b.) & bc1 & 25 & 10 & 40 \\
\hline bc2 [m] & $130 \mathrm{~m}$ constant & hydr. head; limestones & bc2 & 130 & 100 & 110 \\
\hline bc3 $[\mathrm{m}]$ & $0 \mathrm{~m}$ constant & head; conglomerates (clay no flow b.) & bc3 & 0 & 0 & 0 \\
\hline bc4 $[\mathrm{m}]$ & $0 \mathrm{~m}$ constant & hydr. head; limestones & bc4 & 2 & 2 & 2 \\
\hline bc5 $[\mathrm{m}]$ & $0 \mathrm{~m}$ constant & head $=0$ (sea water level) & bc5 & 0 & 0 & 0 \\
\hline bc6 $[\mathrm{m} / \mathrm{d}]$ & $4,81 \times 10^{-4}$ & groundwater recharge & bc6 & $-4,81 \mathrm{e}-4[\mathrm{~m} / \mathrm{d}]$ & $-4,81 \mathrm{e}-4[\mathrm{~m} / \mathrm{d}]$ & $-4,81 \mathrm{e}-4[\mathrm{~m} / \mathrm{d}]$ \\
\hline bc7 & no flow & no flow boundary & bc7 & no flow & no flow & no flow \\
\hline bc8 & $0 \mathrm{~m}$ constant & head = 0 (Aigion well; Lions well) & bc8 & \multicolumn{3}{|c|}{ head $=0$ (Aig well) } \\
\hline \multicolumn{3}{|c|}{ Observation points coordinates: } & \multicolumn{4}{|c|}{$\begin{array}{l}\text { hydraulic head } \\
\text { (calibration parameters): }\end{array}$} \\
\hline 1 & $x:+4946,67 ; y:+12,42$ & surface level (GOK) & 1 [ surface ] & 2,71 & 1,33 & 3,81 \\
\hline 2 & $x:+4946,58 ; y:+0,071$ & 0 ; seawater level & $2[0 \mathrm{~m}]$ & 2,70 & 1,33 & 3,81 \\
\hline 3 & $x:+4941,20 ; y:-215,88$ & 215 m ; PumpTest AIG10C $(211,8-256,4$ m) & $3[215 \mathrm{~m}]$ & 2,68 & 1,32 & 3,77 \\
\hline 4 & $x:+4947,88 ; y:-453,82$ & $450 \mathrm{~m}$; marine clay & $4[450 \mathrm{~m}]$ & 22,21 & 2,33 & 6,13 \\
\hline 5 & $x:+4947,88 ; y:-540,71$ & $540 \mathrm{~m}$; Pindos limestones with radiolarite intercalations & $5[540 \mathrm{~m}]$ & 31,16 & 2,00 & 7,13 \\
\hline 6 & $x:+4941,20 ; y:-635,62$ & $635 \mathrm{~m}$; radiolarites & $6[635 \mathrm{~m}]$ & 30,23 & 2,00 & 6,86 \\
\hline 7 & $x:+4947,88 ; y:-721,17$ & 720 m ; PumpTest AIG10L $(708,8-744,8 \mathrm{~m})$ set point $5 \mathrm{~b}$ & $7[720 \mathrm{~m}]$ & 52,88 & 51,80 & 50,97 \\
\hline 8 & $x:+4949,22 ; y:-781,33$ & $780 \mathrm{~m}$; below Aigio fault; Tripolitza; set point $10 \mathrm{bar}$ & $8[780 \mathrm{~m}]$ & 100,55 & 98,20 & 100,04 \\
\hline 9 & $x:+4953,23 ; y:-1001,89$ & $1001 \mathrm{~m}$; Total Depth & $9 \quad[1001 \mathrm{~m}]$ & 102,13 & 99,99 & 100,62 \\
\hline 10 & $x:+4947,88 ; y:-1156,95$ & $1155 \mathrm{~m}$; total depth of model & $10[1155 \mathrm{~m}]$ & 102,13 & 99,99 & 100,60 \\
\hline \multirow{3}{*}{\multicolumn{2}{|c|}{$\begin{array}{l}\text { Other } \\
\text { Anisotropy factor }=1 \text { (default) } \\
\text { Angle }=0 \text { (default })\end{array}$}} & & & & & \\
\hline & & Density ratio $=0$ (default) & & & & \\
\hline & & Storage compressibility $=1 * 10-4$ (default) & & & & \\
\hline
\end{tabular}

During calibration the sensitivity check by variation of the boundary conditions show that hydraulic head ranges from $5 \mathrm{~m}-45 \mathrm{~m}$ at bc1 (conglomerate graben fill) and $90-160 \mathrm{~m}$ for bc2 (Pindos Fm., Triploitza Fm.). At best solution $40 \mathrm{~m}$ (bc1) and $110 \mathrm{~m}(\mathrm{bc} 2)$ are evolved.

After calibration with all integrated parameters, starting conditions and boundary conditions under countless numerical runs with always different conditions finally the best 3 calibrated hydraulic model versions $[\mathrm{A}],[\mathrm{B}]$ and $[\mathrm{C}]$ are worked out and will be discussed here. A detailed calibration summary of the versions is given in the Tab. VII.2 above: 
Version $[A]$ :

$[\mathrm{A}]$ is the version which resembles most with the attached starting conditions. During calibration the values for Kf3a-c and Kf4 (marine clay - limnic lagoonal sediments) had to correct in all versions to less permeability $\left(3,18 \times 10^{-8}\right.$ to $\left.\sim 10^{-9} \mathrm{~m} / \mathrm{s}\right)$. The hydraulic conductivity derived from AIG10L had to be corrected from $10^{-7}$ to a higher value of $10^{-6} \mathrm{~m} / \mathrm{s}$ and seemed to be more permeable than in AIG10L. The same is done to the Tripolitza limestones below which are as well more permeable than assumed from the production test. The boundary condition bc 1 is fixed to $25 \mathrm{~m}$. It is remarked here that in all versions the Tripolitza limestones on the northern boundary (bc4) seemed to be under more confined conditions. Whereas bc 3 and bc 5 could rest on zero bc4 has to change to $2 \mathrm{~m}$ hydraulic head. The distribution of hydraulic head in version [A] is displayed in Fig. VII.6.

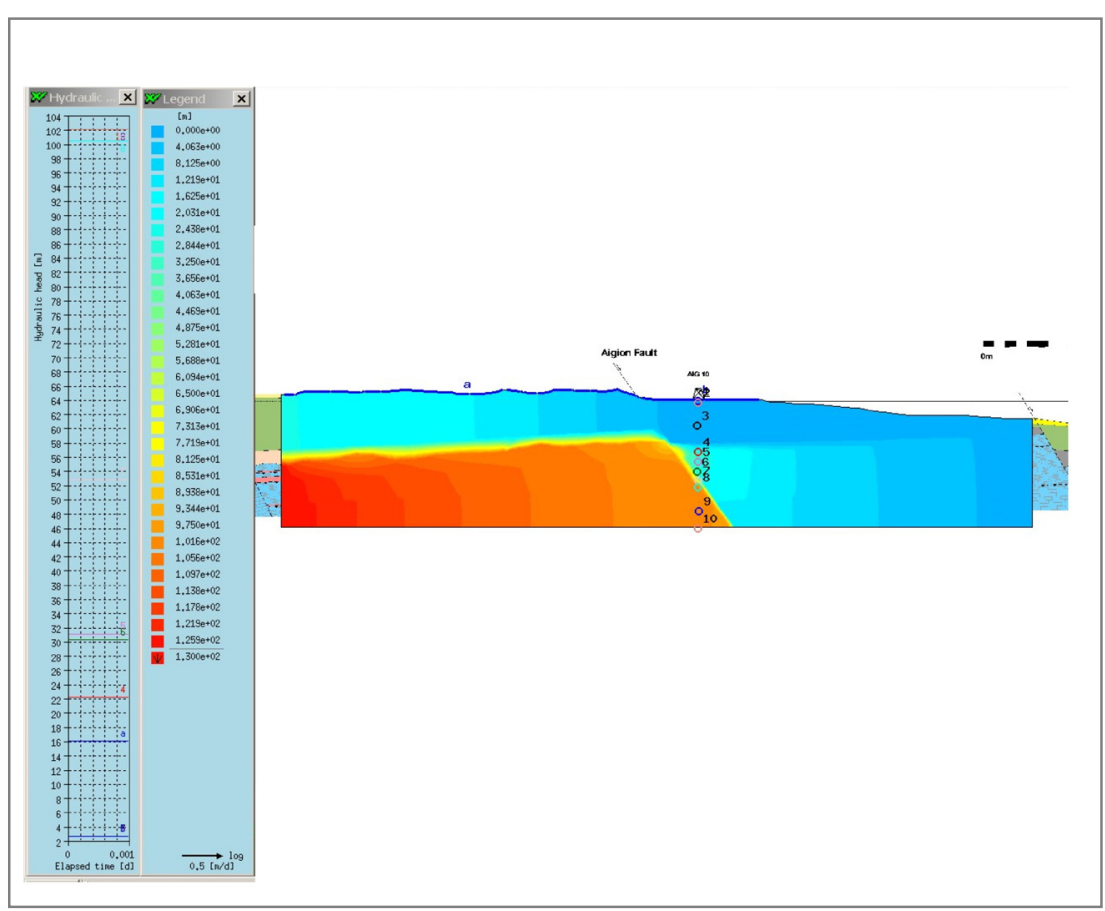

Fig. VII.6: Distribution of hydraulic head in version [A]. The pressure step at the Aigion fault is in compliance with the pre-conditions (left). To build up the pressure difference the fault contacts are attached with different hydraulic conductivities. Below the fault hydraulic head is high where water is inflowing in the model (bc1,2) and is decreasing in the direction to the fault plane where the flux is retained. In the hangingwall flux is low and decreasing to the fixed boundary conditions. Similar behavior are showing the conglomerates above. Here the hydraulic head is lower but is decreasing in flow direction as well until to the fault plane.

Pressure difference could be performed successful on OP7 with $52.88 \mathrm{~m}(720 \mathrm{~m})$ and $100.55 \mathrm{~m}$ at OP8 $(780 \mathrm{~m})$ witch is in-between the criteria (Tab. VII.2). The pronounced pressure step at the fault plane is expressed in the Fig. VII.6. The slightly confined conditions at OP3 (2.67m hydraulic head) corresponds to the results of the pumping test AIG10C as well. Additional the flow paths, flow velocity and overall hydraulic conditions in version [A] are nearly conform with the conceptual model and parameters are in plausible ranges. Otherwise the hydraulic head, respective pressure, in the depths of $540 \mathrm{~m}$ (OP5) and $635 \mathrm{~m}$ (OP6) with $\sim 31 \mathrm{~m}$ are not plausible and are not confirmed by the drill parameters (e.g. drill mud dilution, mud density, flow rate, et. al.). Therefore caution is advised to this aspect in version $[\mathrm{A}]$ when later on geothermal conditions are coupled. 


\section{Version $[B]$ :}

As displayed in Tab. VII.2 the hydraulic conductivities in version [B] attached to the lithological units for Kf5 - Kf12 were raised strongly. It is tried to calibrate the hydraulic flow if we assume karstic conditions not only for the lower Triploitza limestones but also for the Olonos-Pindos limestones. Although the analysis of the pumping tests AIG10L and Selinous valley EQ1 show fractured aquifer conditions karstic conditions for the platy limestones can not be absolute excluded. Very high hydraulic conductivity is given therefore to the units below the marine-lagoonal clays (Kf1-4) with hydraulic conductivities up to $1 \times 10^{-2} \mathrm{~m} / \mathrm{s}$. With a very similar fault behavior than in version [A] except of $f_{11}, f_{13}$ (Tripolitza limestone contact), it was indeed possible to calibrate the version [B] (Fig. VII.7). But here it was necessary to reduce the hydraulic head of the conglomerates (bc1) to $10 \mathrm{~m}$ and that oft the limestones below (bc2) to $100 \mathrm{~m}$. With this reduced hydraulic potential but higher permeability in the lower model part it was able to retain the water at the fault up to the forced fault condition of 5 bar difference ( $51.8 \mathrm{~m}$ vs. $98.20 \mathrm{~m}$ ).

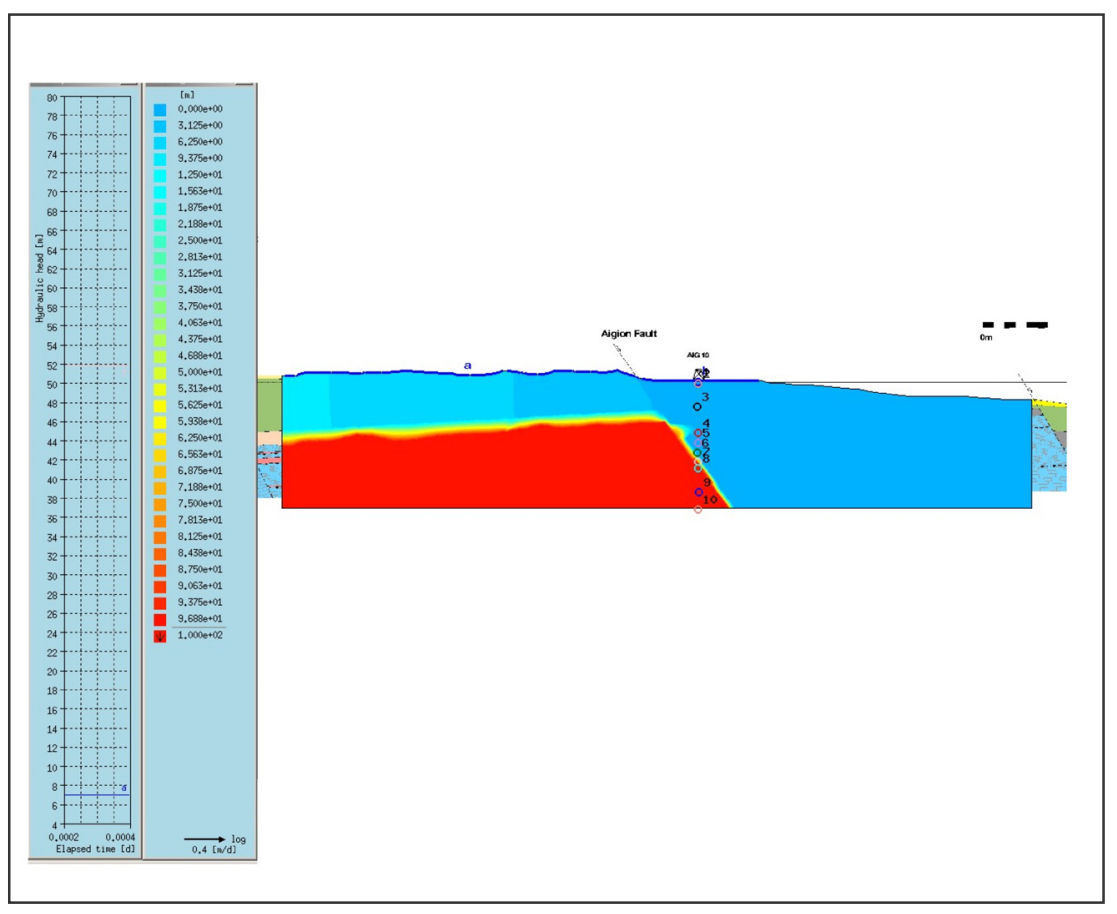

Fig. VII.7: Distribution of hydraulic head in version [B] assuming karstic conditions also for the Olonos-Pindos limestones with high hydraulic conductivity. It was able to retain the water at the fault up to the forced fault condition of 5bar difference with similar fault behavior than [A]. As one can recognize hydraulic head in this version would be homogeneous below the rift sediments of the foot wall (red) and nearly zero at both compartments (filling and basement) of the hangingwall. The hydraulic behavior here would imply stationary flux conditions and only few hydraulic potential in between the conglomerates on top. 
Version $[C]$ :

In Version [C] a successful calibrated hydraulic model could be performed assuming a higher hydraulic potential in the conglomerate aquifer system on top. bc1 is raised to $40 \mathrm{~m}$ (higher values are not plausible) and bc2 is set to $110 \mathrm{~m}$. With this settings the hydraulic fault behavior has to match to this conditions by increasing the permeability. The fault contact $\mathrm{fl}-\mathrm{f} 3$ (conglomerates) could let nearly unchanged but from $\mathrm{f} 4$ down to $\mathrm{f} 14$ the settings had to be changed to much more lower permeability than assumed before. In this scenario pressure difference of 0.5 bar is only possible to reach if hydraulic conductivities in the range of $10^{-9}$ to $10^{-10} \mathrm{~m} / \mathrm{s}$ are considered on the lower fault segments (Tab. VII.2) which means semipermeable or even impermeable fault behavior. Hydraulic conductivities from the lithological units, however, had only to be corrected for the marine clay / limnic lagoonal sediments $\left(10^{-8}\right.$ to $\left.\sim 10^{-9} \mathrm{~m} / \mathrm{s}\right)$. Besides the variation of hydraulic fault behavior the values for the lithological units $(\mathrm{Kf})$ are resembling well with the hydraulic test results.

As well flow paths and overall hydraulic conditions are nearly conform with the conceptual model and parameters are in plausible ranges. In this version the hydraulic head, respective pressure at OP5 $(540 \mathrm{~m})$ and OP6 $(635 \mathrm{~m})$ with $\sim 7 \mathrm{~m}$ are more plausible than in version [A] (Fig. VII.8). OP7 show $50.97 \mathrm{~m}$ hydraulic head in $720 \mathrm{~m}$ bsl and $100.04 \mathrm{~m}$ at OP $8(780 \mathrm{~m})$ witch is very good and in-between the self-criteria. Furthermore the confined conditions at OP3 $(3.77 \mathrm{~m})$ corresponds to the AIG10C hydraulic test results. In general version [C] is the best calibrated hydraulic flow model performed. It is noticed and anticipated here that only this version remains plausible after coupling the thermal heat flow to the model.

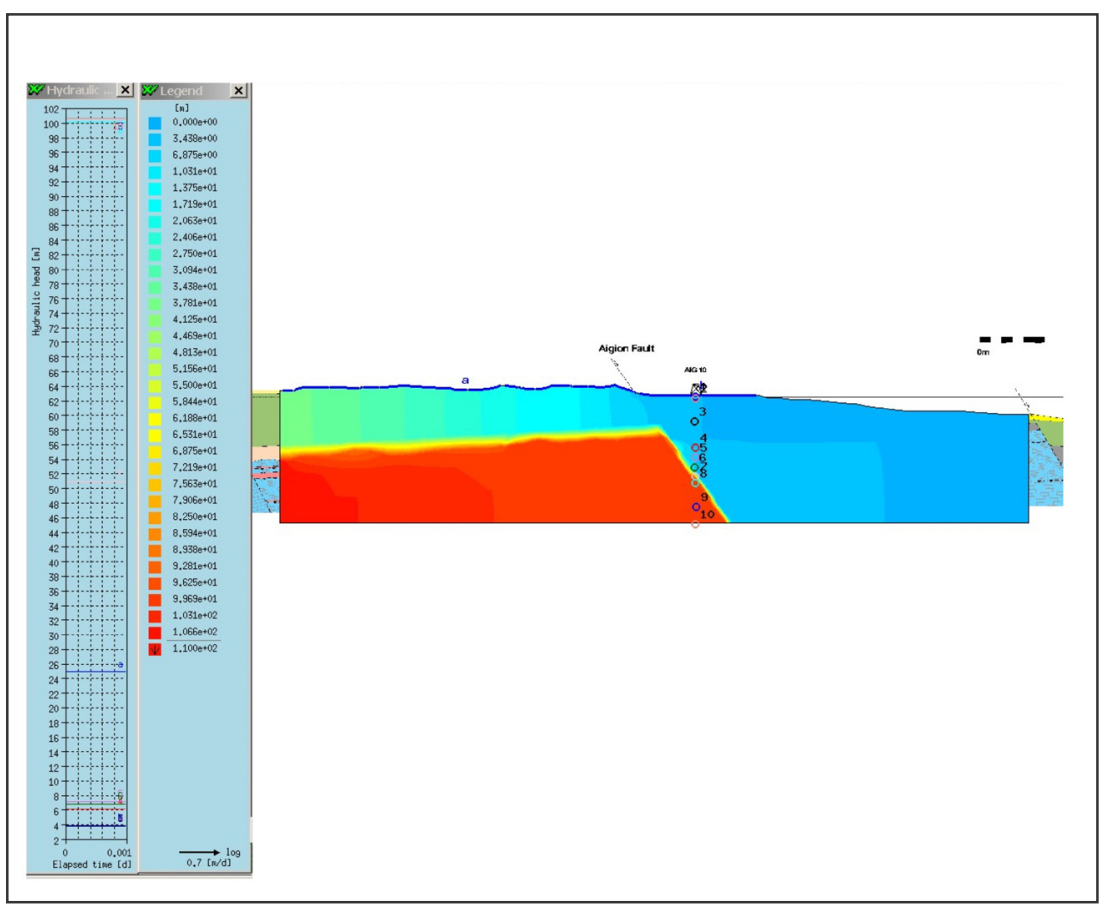

Fig. VII.8: Distribution of hydraulic head in version [C] assuming a higher hydraulic potential in the conglomerate aquifer system on top (bc1) and low hydraulic conductivities in the range of $10^{-9}$ to $-10^{-10} \mathrm{~m} / \mathrm{s}$ on the lower fault segments. The hydraulic head in the conglomerates and the lower parts of the foot wall is decreasing in flow direction. The water flux is retained at the fault plane and the pressure stasis is in compliance with the pre-conditions (left; OP7,8). Version $[\mathrm{C}]$ is reflecting the ideas of the conceptual model very well an it is to be remarked that only this version remains plausible after coupling the thermal heat flow to the model. 


\section{Summary}

It can be summarized that hydraulic numerical models were performed which reflect very good the conditions and assumptions of the hydrogeological conceptual model. From the calibration and plausibility analysis the 3 versions [A], [B], and [C] were rated as the most likely scenarios for hydraulic flow and hydrogeological conditions. From this three scenarios, version [C] seems to be the most suitable version as it is best adapted to the conceptual model. Although version [A] describes a well calibrated hydraulic model, the comparison of observation points in Fig. VII.9 shows a very early increase of pressure which is not recognized during the drilling activities in AIG10 . In contrast version $[\mathrm{B}]$ shows a relatively conform pressure above the fault plane in the hangingwall with a very shallow increase and an abrupt rise from OP6 to OP8.

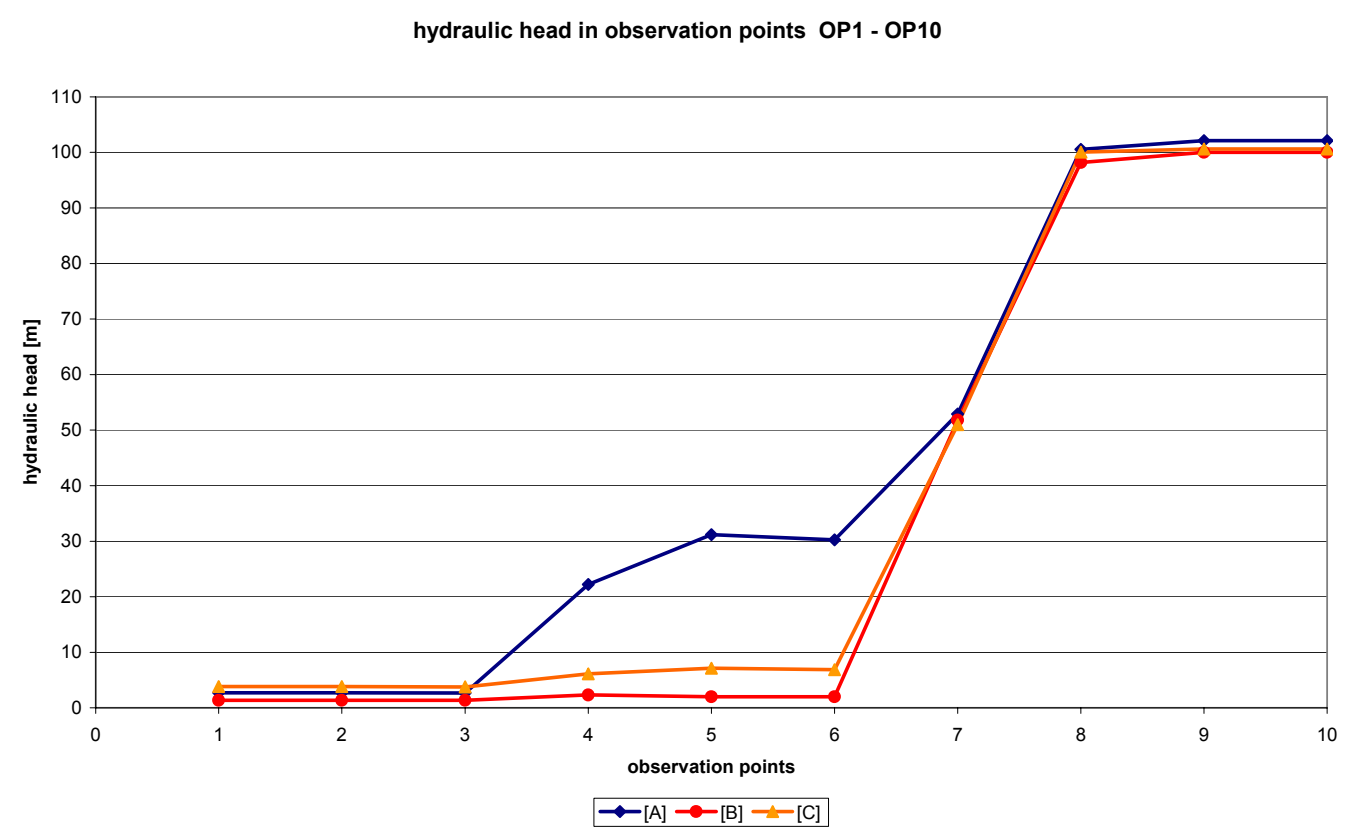

Fig. VII.9: Hydraulic head in observation points OP $1-10$. Version [A] shows an early increase of hydraulic head which is not confirmed by hydraulic investigations. Version [B] shows a relatively good correlation above the fault plane in the hangingwall but the increase of hydraulic head from OP3/4 is slightly too high. Version [C] starts with relatively low hydraulic head from surface and an increase from OP3to OP4, which is plausible, showing minor artesian conditions. The hydraulic fault behavior is expressed in an abrupt rise from OP6 to OP8 and a strong increase to $100 \mathrm{~m}$ hydraulic head.

More likely, and confirmed by the pumping test AIG10C and drilling parameters (Tab. V.1) is the character of the curve of version [C]. Hydraulic head is relatively low from surface down to $215 \mathrm{~m}$ bsl in between the rift sediments (OP1-3). An increase from $388 \mathrm{~m}$ down to $500 \mathrm{~m}$ (OP3-4) is plausible and shows minor artesian conditions, which is confirmed by the hydraulic tests. Towards the OlonosPindos Formation, hydraulic head does not increase in the hangingwall of the normal fault (OP5-6). Below the radiolarite (578-698 mbsl, OP6) and above the fault plane the hydraulic head increases to $50 \mathrm{~m}$ (OP7, $720 \mathrm{mbsl})$ which is derived from the hydraulic test AIG10L (708.8 - $744.8 \mathrm{~m})$. Below the 
fault plane, the pressure difference of $0.5 \mathrm{MPa}$ measured during drilling and the production test in AIG10 is exposed in a strong increase of hydraulic head to $100 \mathrm{~m}$ (OP8, $780 \mathrm{~m})$ in the foot wall. Finally, the production test has shown no significant variations of pressure, so that the calculated graphs at OP9 $(1000 \mathrm{~m})$ and OP10 $(1155 \mathrm{~m})$ are similar. It has to be considered that all calibrated hydraulic models are regarded as some of several possible models, but showing a good fitting in regard to the existing data, the hydrogeological conceptual model, and the success of calibrating.

\section{VII.5 Coupled thermo-hydraulic model}

\section{VII.5.1 Extension of the hydraulic flow model to thermal properties}

To assess the overprint of the regional thermal field by heat advection in the aquifer systems the hydraulic model has been enlarged with thermal properties. For the transport data initial conditions, boundary conditions, and transport material properties for heat or temperature have to be specified. For detailed information about the principles and basic equations for transport modeling see the Reference Manual by Diersch, 2005. The procedure and model design as well as the settings of parameters to the model domain are the same as those used for the hydraulic model construction described in chapter VII.3.2. The supermesh again provides the possibility to attach the thermal properties to the lithological units (Fig. VII.5). The same boundary sections bc1-7 are used for setting temperature on the inflow of water. The transport material menu in FEFLOW ${ }^{\circledR}$ then allows to set the aquifer thickness, porosity, dispersivity, molecular diffusion, transfer rates or source/sink of contaminants (if required). Here some of the possible attachments are not known and default values of FEFLOW $^{\circledR}$ were used (all considered parameters are described in the following subchapters). Similar to the flow model, all boundary conditions are regarded as stationary with a definition of $1^{\text {st }}$ kind boundaries (Dirichlet; temperature) and $2^{\text {nd }}$ kind boundaries (Neumann; heat flow). Transfer- $\left(3^{\text {rd }}\right.$ kind, Cauchy) or Well boundary conditions ( $4^{\text {th }}$ kind) do not need to be specified in the regarded numerical problem. It is noticed here that after the calibration of the thermal properties only one of the three hydraulically calibrated flow models $[\mathrm{A}]-[\mathrm{C}]$ remain useful. It is expected that the thermal structure of the highly permeable sedimentary veneer is closely related to fluid-circulation processes and that intervals of no-flow conditions (conductive heat transport) can be distinguished from intervals of dynamic flow (convective and conductive heat transport).

In summary, the coupled thermo-hydraulic model involves in detail:

- net generated cross section with geological structure, lithology, and tectonics;

- lateral and vertical extension of known aquifers and aquicludes, major faults and the definition of model boundaries;

- calculated water input data, such as effective infiltration from rainfall, seepage, and leakages;

- possible vertical contacts between the individual aquifer systems (leakage, hydraulic bypass);

- hydrogeological parameters, such as hydraulic conductivity, transmissivity, porosity, anisotropy factor between vertical and horizontal hydraulic conductivity; 
- thermal, petrophysical, and hydraulic coherences such as thermal gradients, conductive and convective interaction, thermal conductivity from laboratory measurements on core and surface samples;

- hydrochemical analyses and origin of groundwater, storage area;

- groundwater dating; transition time, GW-velocity, flow paths;

\section{VII.5.2 Plausibility check and starting conditions for thermal properties}

The tables Tab. VII.8, Tab. VII.9, and Tab. VII.10 at the end of this chapter display the summary of starting conditions attached to the thermo-hydraulic models [A], [B], and [C]. The supermesh elements $\mathrm{Kf}$ and $\mathrm{f}$ are set with well-log derived porosity values and thermal conductivities for the lithological units which were laboratory corrected by the well-log results as described in chapter VI. The extended coupled fluid flow/heat flow model was calibrated by the DTS-temperature-depth profile (right table side). Two different approaches for the lower thermal boundary bc 7 were investigated by trial and error: first, a temperature boundary; second, a heat flow boundary. A boundary with different attached heat flow values (constant) finally was preferred over other scenarios.

For the calibration of the geothermal model and the control of the hydraulic behavior in the system several possibilities are implemented in the model:

- hydraulic conductivity parameters $\left(\mathrm{k}_{\mathrm{f}}\right.$-values in $\left.\mathrm{m} / \mathrm{s}\right)$ from the calibrated hydraulic model are fixed on the supermesh elements and hydraulic head were observed in the observation points OP1-10 and the AIG10 profile. They are not allowed to change in high variation and should stay in the range of the calibrated hydraulic flow model values.

- thermal parameters (matrix TC in $\mathrm{W} / \mathrm{mK}$ ) attached to the supermesh elements control the thermal conductivity of the lithological units $\mathrm{Kf}_{1}-\mathrm{Kf}_{12}$.

- thermal conductivity parameters attached to the supermesh elements $f_{1}-f_{14}$ control the thermal behavior of the normal fault plane.

- temperature is set on the boundary conditions bc $1-$ bc6 derived e.g. from surface temperature, seawater temperature or annual air temperature.

- heat flow is set to the lower boundary bc7 to control the energy input from depth.

- results on temperature after model runs can be observed along the borehole profile.

- a calculated geotherm can be correlated with the measured DTS values and can additionally be observed in the observation points OP1-10. 


\section{VII.5.2.1 Thermal conductivity attributed to the lithological elements}

As described in chapter VI thermal conductivity and porosity was determined on 32 surface and core samples and are averaged according to the proportions of the lithotype mixture. The values attached to the supermesh are the matrix thermal conductivities (matrix TC, $\phi=0$ ), which then will be adjusted to the well $\log$ porosity and respectively formation porosity by the simulation program FEFLOW ${ }^{\circledR}$ (Tab. VII.3). These values represent the starting conditions for all calibrated hydraulic flow models [A], [B] and $[\mathrm{C}]$. It is expected that the initial thermal conductivities (matrix related), after the modeling run, show less values due to the adjustment to well log porosity. Thus the model result should show the following values (Tab. VII.3):

Tab. VII.3: Matrix related thermal conductivities and expected numbers after modeling.

\begin{tabular}{l|l|c|c}
\hline lithology & supermesh & $\begin{array}{l}\text { initial value } \\
\text { (matrix TC) } \\
{[\mathrm{W} / \mathrm{m} / \mathrm{K}]}\end{array}$ & $\begin{array}{l}\text { expected value } \\
\text { (corrected TC) } \\
{[\mathrm{W} / \mathrm{m} / \mathrm{K}]}\end{array}$ \\
\hline rift fill conglomerates & $\mathrm{Kf}_{1}-\mathrm{Kf}_{2}$ & 2.86 & 1.53 \\
rift fill marine sediments & $\mathrm{Kf}_{3}-\mathrm{Kf}_{4}$ & 1.74 & 1.71 \\
Olonos-Pindos radiolarite $\mathrm{Fm}$. & $\mathrm{Kf}_{5}-\mathrm{Kf}_{6}$ & 3.62 & 2.77 \\
Olonos-Pindos limestone $\mathrm{Fm}$ & $\mathrm{Kf}_{7}-\mathrm{Kf}_{8}$ & 2.70 & 2.32 \\
Tripolitza limestone & $\mathrm{Kf}_{9}-\mathrm{Kf}_{12}$ & 2.86 & 2.09 \\
\hline
\end{tabular}

\section{VII.5.2.2 Thermal conductivity attributed to the fault elements}

For the fault plane and respective fault elements $\left(f_{1}-f_{14}\right)$, no detailed analysis of thermal properties were available. It was decided to use the same values for the starting conditions as for the lithological units $\mathrm{Kf}_{1-12}$. As well, thermal conductivities should be lower than the initial values after the numerical calculation. In the following table the settings on the supermesh elements are displayed (Tab. VII.4):

Tab. VII.4: Thermal conductivities attached to the fault elements.

\begin{tabular}{l|l|c}
\hline fault contact & fault elements & $\begin{array}{c}\text { attached thermal } \\
\text { conductivity [W/m/K] }\end{array}$ \\
\hline conglomerate contact & $\mathrm{f}_{1-4}, \mathrm{f}_{6}$ & 2.86 \\
rift fill marine sediments & $\mathrm{f}_{5}, \mathrm{f}_{8}$ & 1.74 \\
Olonos-Pindos radiolarite Fm. & $\mathrm{f}_{7}, \mathrm{f}_{10}$ & 3.62 \\
Olonos-Pindos limestone Fm & $\mathrm{f}_{9}, \mathrm{f}_{12}$ & 2.70 \\
Tripolitza limestone & $\mathrm{f}_{11}, \mathrm{f}_{13-14}$ & 2.86 \\
\hline
\end{tabular}




\section{VII.5.2.3 Porosity in the coupled model}

As described in V.3.2, parameters for the formation porosity is determined from sonic and resistivity $\operatorname{logs}$ of AIG10. The adjustment of the thermal conductivity from laboratory measurements to well $\mathrm{log}$ porosity is generated by FEFLOW ${ }^{\circledR}$. The permeability of the normal fault plane is assumed to be very low due to cataclasation and/or mylonitisation of the adjacent fault plane rocks. An average value of $3 \%$ is set on the fault plane segments. The attached starting conditions for formation porosity to the supermesh elements are (Tab. VII.5):

Tab. VII.5: Well log derived porosity attached to the supermesh elements.

\begin{tabular}{l|c}
\hline supermesh & $\begin{array}{c}\text { Well log derived porosity } \\
{[\%]}\end{array}$ \\
\hline $\mathrm{Kf}_{1}-\mathrm{Kf}_{2}$ & 40 \\
$\mathrm{Kf}_{3}-\mathrm{Kf}_{4}$ & 1.5 \\
$\mathrm{Kf}_{5}-\mathrm{Kf}_{6}$ & 15 \\
$\mathrm{Kf}_{7}-\mathrm{Kf}_{8}$ & 10 \\
$\mathrm{Kf}_{9}-\mathrm{Kf}_{10}$ & 30 \\
$\mathrm{Kf}_{11}-\mathrm{Kf}_{12}$ & 20 \\
$\mathrm{f}_{1-14}$ & 3 \\
\hline
\end{tabular}

\section{VII.5.2.4 Boundary conditions for temperature and heat flow}

\section{- Temperature set on model boundaries $b c 1-b c 6$}

The annual surface temperature in Greece averages at $18.1^{\circ} \mathrm{C}$. Nevertheless water sampled in springs and pumping stations from the conglomerate aquifer show temperatures of $11-15^{\circ} \mathrm{C}$. Assuming a mixture between the shallow water coming from the southern adjacent area in the conglomerates and the rainwater from surface a average temperature of $15^{\circ} \mathrm{C}$ is set on the model boundary bc1. bc 2 then describes the inflow of the calcium-carbonate water recharged in the hinterland and with the origin mainly from the Olonos-Pindos Formation. Assuming a temperature increase with depth on this boundary condition an estimated water temperature of $16-35^{\circ} \mathrm{C}$ versus depth is given. On the northern model boundary bc 3 and 4 are not characterized with temperature and can be observed if the resulting values after numerical calculation is in plausible ranges. In contrast seawater temperature is known in the area and the relatively cold annual average temperature (for deeper water depths) of $11^{\circ} \mathrm{C}$ is chosen for the starting conditions on bc5. The overprinted temperature on the input of hydraulic flux into the model domain by precipitation bc6 is given by the annual air temperature in Greece of $18.1^{\circ} \mathrm{C}$ and is rounded to $18^{\circ} \mathrm{C}$. 


\section{- Heat flow set on model boundary bc7}

In the hydraulic flow model the lower model boundary bc7 is characterized as a no flow boundary and no energy is able to cross. The lower part is therefore independent from hydraulic influences at depth and is treated as impervious to flow entering or leaving the model domain. Setting a fixed temperature on this boundary would result in a forced temperature value for the numerical calculations. However, several trials with this procedure did not succeed. Instead a boundary with heat flow derived from the temperature gradient plot was preferred over other scenarios. The Tab. VII.6 below displays the heat flow values relating to depth intervals and lithology. Detailed calculations of heat flow were given in chapter V.3.3. For the starting conditions of heat flow on bc7 the average value is rounded to 50 $\mathrm{mW} / \mathrm{m}^{2}$.

Tab. VII.6: Heat flow of depth intervals derived along the AIG10 borehole profile.

\begin{tabular}{l|l}
$\begin{array}{l}\text { Depth } \\
\begin{array}{l}\text { Interval } \\
(\mathrm{m})\end{array}\end{array}$ & $\begin{array}{l}\text { Heat Flow } \\
\left(\mathrm{mW} / \mathrm{m}^{2}\right)\end{array}$ \\
\hline $160-380$ & 41.8 \\
$380-485$ & 49.6 \\
$485-700$ & 50.5 \\
$700-740$ & 60.0 \\
\hline \multicolumn{2}{|c}{ average: $50.5 \mathrm{~mW} / \mathrm{m}^{2}$} \\
\hline
\end{tabular}

\section{VII.5.3 Calibration and results of the coupled model}

The basic principle for the calibration of the coupled thermo-hydraulic models [A], [B], and [C] is the correlation of the numerically calculated geothermal profile to the profile measured by DTS in AIG10. In addition, single point temperature values picked along the DTS temperature log at the same depths as the location of the observation points OP1-10 are analyzed and correlated in respect to the calculated values at these OP's. The calibration procedure for each model versions $[\mathrm{A}]-[\mathrm{C}]$ can be followed in the tables Tab. VII.8, Tab. VII.9, and Tab. VII.10. The thermal conductivity parameters of the starting conditions (left side of the tables) were verified until the computed temperatures were relatively equal to the DTS temperatures (right side of the tables). The same procedure is applied to the boundary conditions bc1-10. The average heat flow for the AIG10 profile of $50 \mathrm{~mW} / \mathrm{m}^{2}$ is set as a starting condition on the lower model boundary bc7. Simultaneously, also modeling runs with boundary conditions between $40 \mathrm{~mW} / \mathrm{m}^{2}$ and $60 \mathrm{~mW} / \mathrm{m}^{2}$ were made. For the attachment of the thermal parameters to the supermesh elements it has to pay attention that all conductivity values are available in $\mathrm{J} / \mathrm{m}^{2} / \mathrm{d}$ which is required by $\mathrm{FEFLOW}^{\circledR}$. 
In summary the following possibilities are implemented in the model to control the thermo-hydraulic calibration in the system:

- variation of thermal conductivity parameters attached to the supermesh $\mathrm{Kf}_{1-12}$ and $\mathrm{f}_{1-14}$.

- variation of a constant heat flow at the lower boundary bc7.

- variation of temperature values attached to the boundaries with hydraulic flow bc1-6.

- observation, that the calibrated flow model persist.

The results for the model versions [A], [B], and [C] (displayed in the tables Tab. VII.8, Tab. VII.9, and Tab. VII.10 at the end of this chapter) represent only the very best solutions described. Each version consists of several scenarios. In general the numerically calculated values for the thermal conductivities fit relatively well with the expected values. Also the boundary conditions show relatively good correlation with the initial values: the annual surface temperature (bc1) is calculated 1$3^{\circ} \mathrm{C}$ higher than the initial one and ranges between $15-20^{\circ} \mathrm{C}$. bc 2 is found to be 18 to $32^{\circ} \mathrm{C}$ in all versions $[\mathrm{A}]-[\mathrm{C}]$ whereas the seawater ground temperature $(\mathrm{bc5})$ is calculated to be $9^{\circ} \mathrm{C}$ (initial: $11^{\circ} \mathrm{C}$ ). The influence by precipitation on bc6 is calculated to $15^{\circ} \mathrm{C}$ (version [A]) and little higher in [B] (between 16 and $17^{\circ} \mathrm{C}$ ) and between $15-20^{\circ} \mathrm{C}$ in the scenarios of version [C]. Additionally, in all versions and their scenarios the hydraulic flow conditions stay stable and the calibration factors remain in the range of the calibration requirements.

Although the above correlated boundary conditions and attached thermal conductivities give evidence that the thermal parameters fit to the calibrated thermo-hydraulic model, the geothermal profiles of the versions $[\mathrm{A}],[\mathrm{B}]$, and $[\mathrm{C}]$ instead show large deviations in respect to the DTS profile. But curve fitting of the DTS log with the numerical calculated temperature profile of each of the versions is the basic principle for the calibration. The results are displayed in the figures Fig. VII.10 - Fig. VII.14.

Using the hydraulically calibrated version [A] it was not possible to generate a good curve fitting with the DTS $\log$ in the lower parts of the model. Fitting of the three version [A]-scenarios [A]-1, [A]-2, and [A]-3 was successful only in the upper conglomerate sequence from 100 to $300 \mathrm{~m}$ bsl (Fig. VII.10). In general, the observed temperatures are too high in respect to the DTS log. Also the AIG10 end depth temperature could not be reached. The modeled temperatures of the coupled thermohydraulic model version [A] with $35.19-35.72^{\circ} \mathrm{C}$ at $1155 \mathrm{~m}$ therefore should be regarded unlikely. 

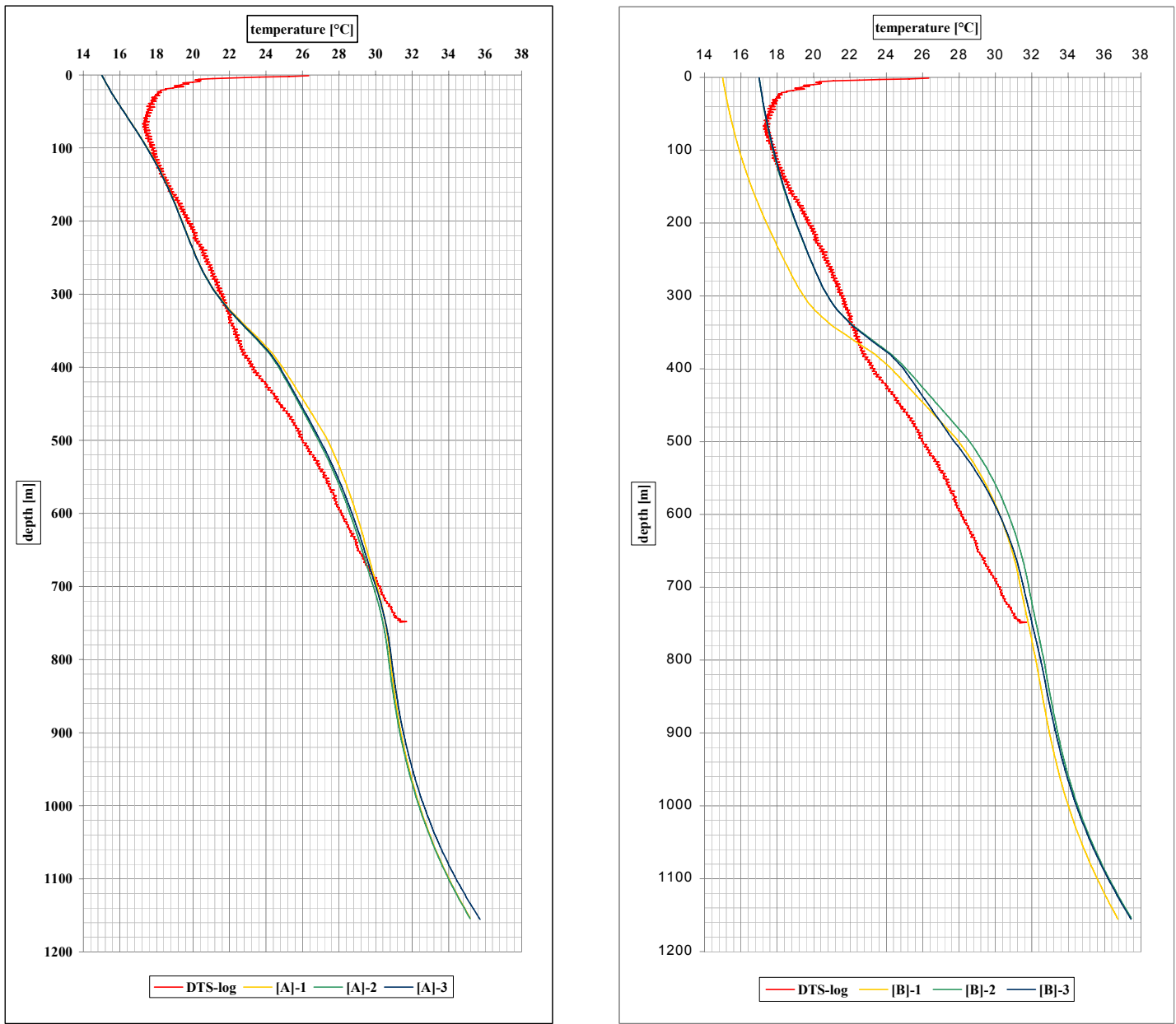

Fig. VII.10 (left): Modeled temperature profiles of the hydraulically calibrated model version [A] versus measured DTS temperature log. Fitting at lower parts in the scenarios [A]-1, [A]-2, and [A]-3 is non-satisfactory.

Fig. VII.11 (right): Modeled temperature profiles of the hydraulically calibrated model version [B] vs. measured DTS-log. The geothermal fitting with the DTS-log for the three [B]-scenarios are non-satisfactory when coupled with thermal parameters.

Non-satisfactory results also are given by the [B]-scenarios [B]-1, [B]-2, and [B]-3 (Fig. VII.11). In this hydraulic flow calibrated version, in which karst conditions for the Olonos-Pindos platy limestones are assumed, it was not possible to fit any numerically calculated temperature profile with the DTS log. This failure of curve fitting together with the fractured aquifer conditions known from the pumping test results give evidence that karstic conditions can be excluded for the Olonos-Pindos limestones. The temperatures at the observation points OP1-10 differ as well and are too high compared to the measured values (Fig. VII.12b). 


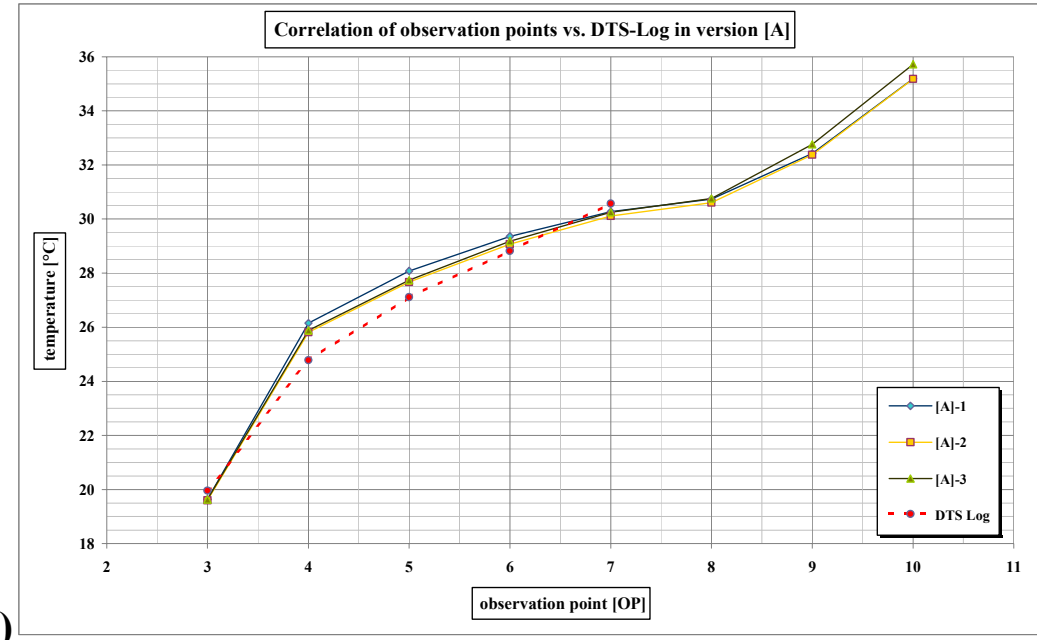

a)

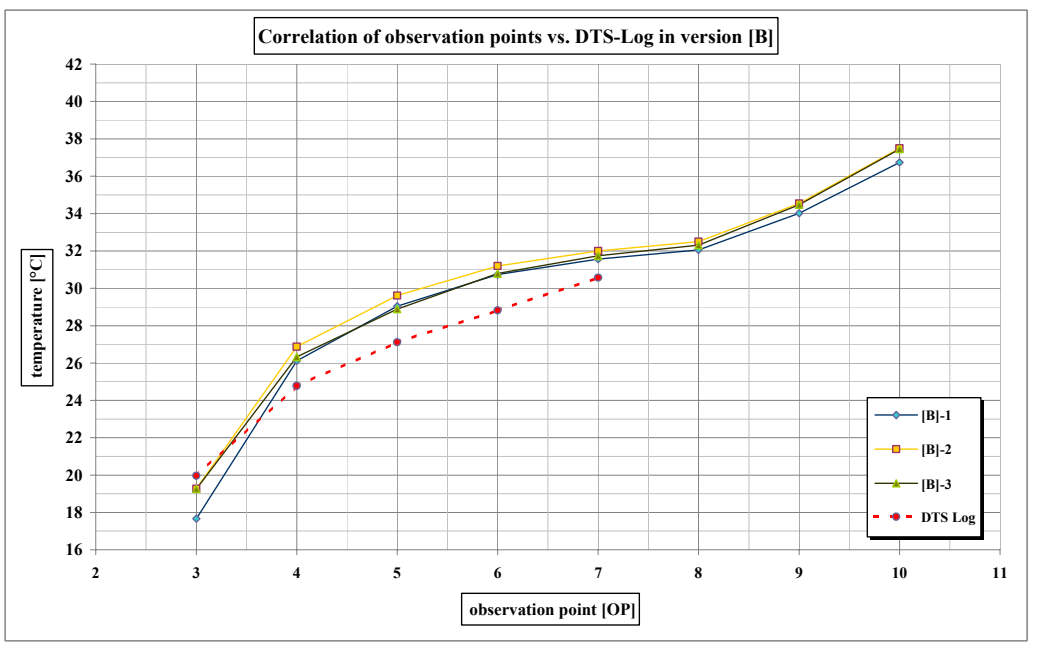

Fig. VII.12: Correlation of the calculated temperature values in the observation points OP1-10 with temperatures picked from the DTS geothermal profile for a) model scenarios [A] and for b) model scenarios [B].

Relative good results could be performed with the hydraulically calibrated version [C]. In figure Fig. VII.13a the four very best thermally calibrated scenarios are displayed. From top curve fitting to the DTS log is only possible in a rough way. But as seen on the DTS profile the log is influenced from surface ground temperature as well and results not before $150 \mathrm{~m}$ bsl are of interest. From $200 \mathrm{~m}$ down to $750 \mathrm{~m}$ then the calculated temperature profile show very good fitting results to the measured DTS $\log$. In this well calibrated model version [C] modeling runs with heat flow boundary conditions of $40 \mathrm{~mW} / \mathrm{m}^{2}, 50 \mathrm{~mW} / \mathrm{m}^{2}, 55 \mathrm{~mW} / \mathrm{m}^{2}$ and $60 \mathrm{~mW} / \mathrm{m}^{2}$ were performed (Tab. VII.10). Numbers above $60-70 \mathrm{~mW} / \mathrm{m}^{2}$ and below $40 \mathrm{~mW} / \mathrm{m}^{2}$ arose in implausible results and can be excluded. The results compared to the DTS log in figure Fig. VII.13 show well curve fitting especially at the lower parts from $200 \mathrm{~m}$ bsl. 
The parameters for thermal conductivities in [C]-1 attached to the lithological formations $\mathrm{Kf}_{1-12}$ and $\mathrm{f}_{1-14}$ are showing relatively less values in respect to the influence of formation porosity. Additionally the observation points of [C]-1 show low temperature values compared to the DTS values (Fig. VII.14). Therefore, it was tried in scenario [C]-2 to fix the well-log adjusted porosities to the lithology prior the model run. With the attachment of $50 \mathrm{~mW} / \mathrm{m}^{2}$ on bc7 and a slight increase from $15^{\circ} \mathrm{C}$ to $17^{\circ} \mathrm{C}$ on bc1 it was possible to calibrate [C]-2 (Fig. VII.13a). On the other hand the entire profile is slightly diverging in details from the DTS log and temperatures at the observation points are partly too low indicating that heat flow from depth is underestimated by $50 \mathrm{~mW} / \mathrm{m}^{2}$ (Fig. VII.14).
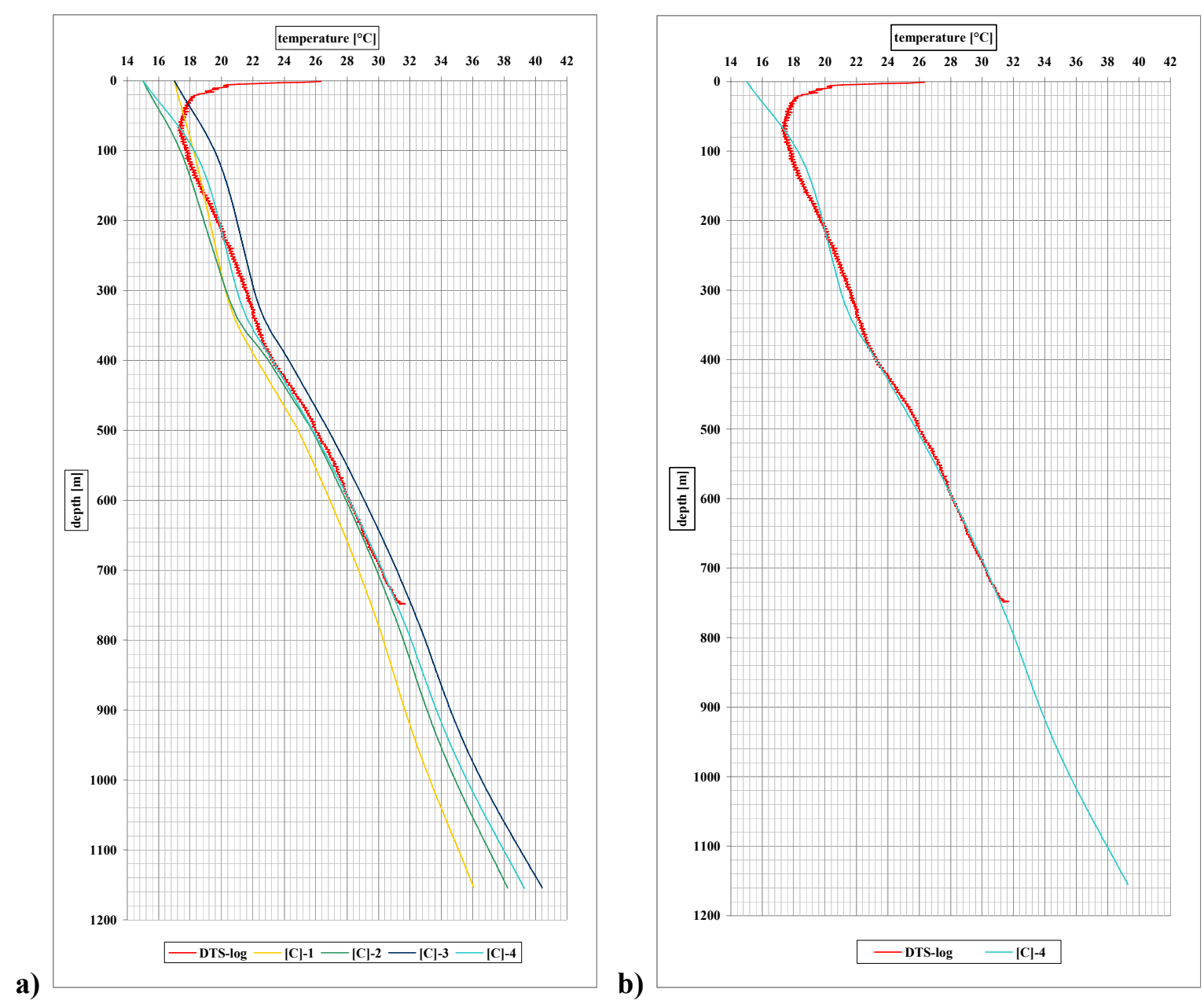

Fig. VII.13: Modeled temperature profiles of the hydraulically calibrated model version [C] vs. measured DTS$\log$. The geothermal fitting to the DTS-log for the [C]-scenarios are arranged in a small spectrum between [C]-1 and $[\mathrm{C}]-3$ a) (explanations see text). The most satisfying scenario is represented by $[\mathrm{C}]-4 \mathbf{b}$ ).

Assuming $60 \mathrm{~mW} / \mathrm{m}^{2}$ at the lower model boundary bc 7 for heat flow (scenario [C]-3) the temperature calibration got worse compared to the measured DTS log. [C]-3 results in slightly too high thermal conductivities in respect to the measured values. The observed single temperature values in OP1-10 therefore diverge from the measured values (Fig. VII.14). Hence, a heat flow value of $60 \mathrm{~mW} / \mathrm{m}^{2}$ or above appears to be implausible and can be excluded. 
Finally [C]-4 represents the very best calibrated model scenario. Figure Fig. VII.13b highlights the calculated temperature profile [C]-4 plotted against the measured DTS log. The profile fits very well from $180 \mathrm{~m}$ depth down to the DTS end logging depth of $745 \mathrm{~m}$. Also the break in the curve at approx. $400 \mathrm{~m}$, where marine clay is encountered in the profile causing a higher interval temperature gradient can be recognized.

In the lower part from $498 \mathrm{~m}$ depth the curve exposes a smaller temperature gradient of the OlonosPindos Formation until the Tripolitza limestone is reached at $770 \mathrm{~m}$. From $770 \mathrm{~m}$ the modeled profile is increasing again, indicated by a curvature from $800 \mathrm{~m}$ down to approx. $1000 \mathrm{~m}$. It is very likely that hydraulic flow in the karstic Tripolitza limestones causes a reduced temperature gradient, which is expressed in the lowering of the curve. Following the curve down to the lowest model domain, the calculated geothermal profile exposes again a slight increase from $1000 \mathrm{~m}$ and is ending with a temperature of about $40^{\circ} \mathrm{C}$ at $1155 \mathrm{~m}$ depth.

Except for the conglomerates $\mathrm{Kf}_{1}-\mathrm{Kf}_{2}$, the thermal conductivities derived from numerical modeling correspond sufficiently to the expected values, when formation porosity is taken into account (Tab. VII.7):

Tab. VII.7: Comparison of thermal conductivities in model scenario [C]-4.

\begin{tabular}{l|c|c}
\hline supermesh & well log adjusted TC $[\mathrm{W} / \mathrm{m} / \mathrm{K}]$ & scenario $[\mathrm{C}]-4 \mathrm{TC}[\mathrm{W} / \mathrm{m} / \mathrm{K}]$ \\
\hline $\mathrm{Kf}_{1}-\mathrm{Kf}_{2}$ & 1.53 & 2.30 \\
$\mathrm{Kf}_{3}-\mathrm{Kf}_{4}$ & 1.71 & 1.70 \\
$\mathrm{Kf}_{5}-\mathrm{Kf}_{6}$ & 2.77 & 2.30 \\
$\mathrm{Kf}_{7}-\mathrm{Kf}_{8}$ & 2.32 & 2.55 \\
$\mathrm{Kf}_{9}-\mathrm{Kf}_{12}$ & 2.09 & 2.79 \\
\hline
\end{tabular}

As described in chapter VI the thermal parameters for the conglomerates are not well constraint. The value of $2.30 \mathrm{~W} / \mathrm{m} / \mathrm{K}$ from [C]-4 differs much from $1.53 \mathrm{~W} / \mathrm{m} / \mathrm{K}$ for well-log adjusted thermal conductivity. One explanation would be that the well-log porosity would be overestimated for the conglomerates or that the matrix TC is not typical for this formation. Third, a insufficiently evaluated formation porosity from well $\log$ is possible. Therefore the values of $2.3-2.4 \mathrm{~W} / \mathrm{m} / \mathrm{K}$ derived from the calibration appear more plausible. The TC value of $2 \mathrm{~W} / \mathrm{m} / \mathrm{K}$, attributed to the fault plane segments seems applicable. 


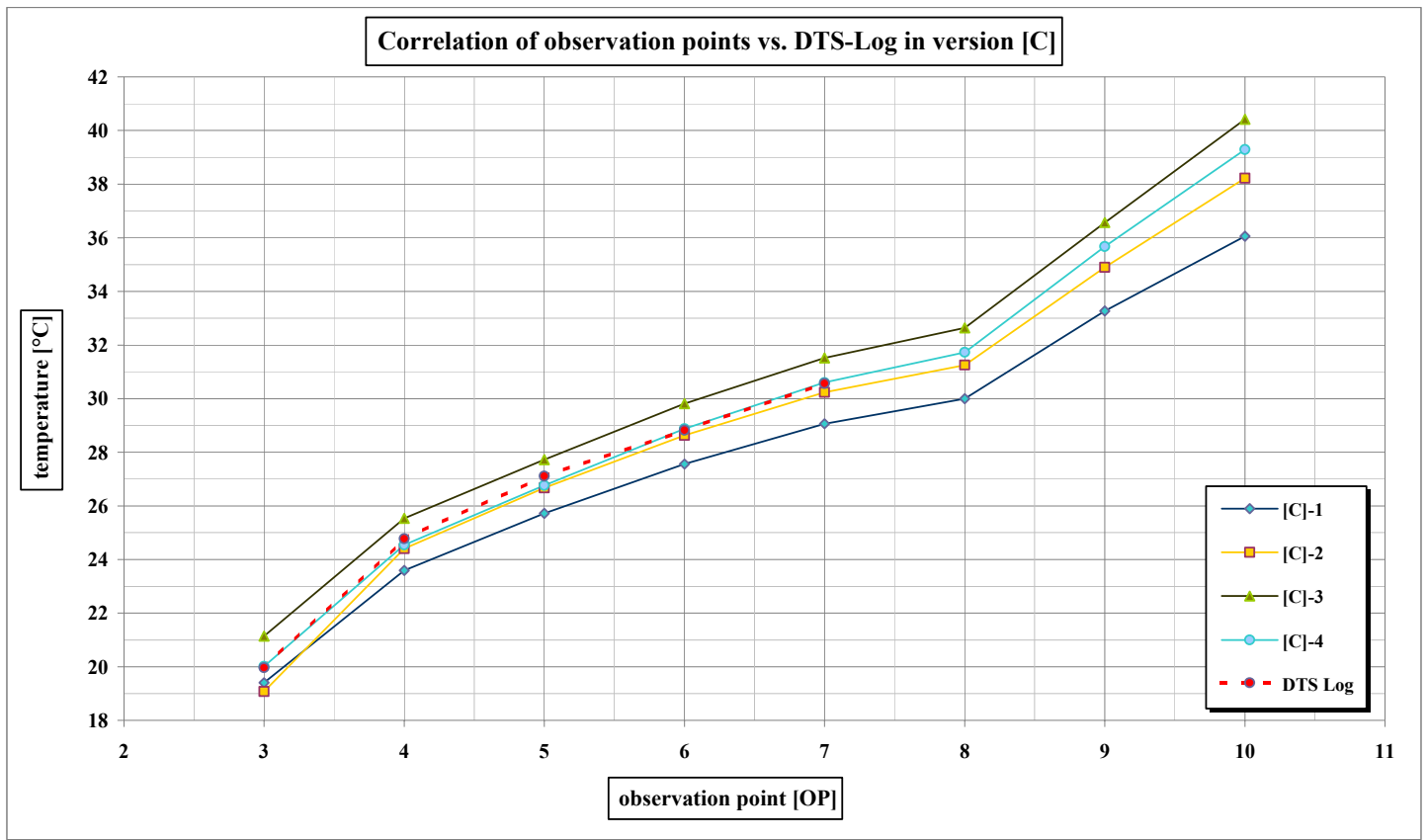

Fig. VII.14: Modeled local temperatures of the hydraulically calibrated model version [C] vs. measured DTS$\log$.

The model results of [C]-4 (Tab. VII.10) show for the implemented temperatures on the southern boundary bc1 (hydraulic flow in the conglomerates) temperatures of $17^{\circ} \mathrm{C}$ from surface and an increase to $18^{\circ} \mathrm{C}$. This value corresponds with the annual average air temperature in the Achaia region of $18^{\circ} \mathrm{C}$. For bc2 $(498 \mathrm{~m}-1155 \mathrm{~m} \mathrm{bsl})$ a linear increase from $18^{\circ} \mathrm{C}$ at top of the Olonos-Pindos Formation to $32^{\circ} \mathrm{C}$ at the lower model domain boundary depth has arise. This corresponds approximately with the water temperature measured at the total depth of the AIG10 borehole and the production test (Tab. VII.10).

In Fig. VII.14 the single temperature values from the observation points (Tab. VII.10) are plotted against the measured data from the DTS log to recognize the band width of the different model scenarios [C]-1 - [C]-4. [C]-4 fits very well with the DTS data and confirms the good correlation of the DTS log versus modeled temperature profile.

Heat flow of the calibrated model [C]-4 is determined to be $55 \mathrm{~mW} / \mathrm{m}^{2}$ (Tab. VII.10) and is slightly higher than the average heat flow of $50.5 \mathrm{~mW} / \mathrm{m}^{2}$ for the AIG10 site. With this heat flow setting on the lowermost boundary bc7 temperature is estimated at depth where no measured DTS data are available after the relative movement of the Aigion fault $(760 \mathrm{~m})$. The correlation of temperatures in figure Fig. VII.13b with good correlation to the DTS values down to $720 \mathrm{~m}$ show $30.60^{\circ} \mathrm{C}$ (DTS: $30.57^{\circ} \mathrm{C}$ ). In $780 \mathrm{~m}, 31.73^{\circ} \mathrm{C}$ is obtained and is increasing up to $35.67^{\circ} \mathrm{C}$ at $1001 \mathrm{~m}$ (bottom hole). At the lower model boundary in $1155 \mathrm{~m}$ modeled temperature reaches $39.29^{\circ} \mathrm{C}$. 
Tab. VII.8: Summary of values and starting conditions (left) for the numerical thermo-hydraulic model [A].

\begin{tabular}{|c|c|c|c|c|c|c|c|}
\hline Supermesh & $\begin{array}{l}\text { well log derived } \\
\text { porosity value [\%] } \\
\text { starting condition }\end{array}$ & $\begin{array}{l}\text { corrected thermal } \\
\text { conductivity } \\
\text { (matrix TC) } \\
{[\mathrm{W} / \mathrm{m} \mathrm{K}]} \\
\text { starting condition } \\
\text { value }\end{array}$ & Supermesh & $\begin{array}{c}{[\mathbf{A}]-1} \\
{[\mathrm{~W} / \mathrm{m} \mathrm{K}]}\end{array}$ & $\begin{array}{c}{[\mathrm{A}]-2} \\
{[\mathrm{~W} / \mathrm{m} \mathrm{K}]}\end{array}$ & $\begin{array}{c}{[\mathrm{A}]-3} \\
{[\mathrm{~W} / \mathrm{m} \mathrm{K}]}\end{array}$ & DTS Log \\
\hline Kf1 & 40 & 2.86 & Kf1 & 2,40 & 2,60 & 2,60 & $\overline{---}$ \\
\hline Kf2 & 40 & 2.86 & Kf2 & 2,40 & 2,60 & 2,60 & --- \\
\hline Kf3a & 1.5 & 1.74 & Kf3a & 1,70 & 2,30 & 2,30 & --- \\
\hline Kf3b & 1.5 & 1.74 & Kf3b & 1,70 & 2,20 & 2,20 & --- \\
\hline Kf3c & 1.5 & 1.74 & Kf3c & 1,70 & 2,20 & 2,20 & --- \\
\hline Kf4 & 1.5 & 1.74 & Kf4 & 1,70 & 2,20 & 2,20 & --- \\
\hline Kf5 & 15 & 3.62 & Kf5 & 2,30 & 2,40 & 2,40 & --- \\
\hline Kf6 & 15 & 3.62 & Kf6 & 2,30 & 2,40 & 2,40 & --- \\
\hline Kf7 & 10 & 2.70 & Kf7 & 2,55 & 2,55 & 2,55 & --- \\
\hline Kf8 & 10 & 2.70 & Kf8 & 2,55 & 2,55 & 2,55 & --- \\
\hline Kf9 & 30 & 2.86 & Kf9 & 2,79 & 2,79 & 2,79 & --- \\
\hline Kf10 & 30 & 2.86 & Kf10 & 2,79 & 2,79 & 2,79 & --- \\
\hline Kf11 & 20 & 2.86 & Kf11 & 2,79 & 2,79 & 2,79 & --- \\
\hline Kf12 & 20 & 2.86 & Kf12 & 2,79 & 2,79 & 2,79 & --- \\
\hline f1 & 3 & 2.86 & f1 & 2,40 & 2,60 & 2,60 & --- \\
\hline f2 & 3 & 2.86 & f2 & 2,40 & 2,60 & 2,60 & --- \\
\hline f3 & 3 & 2.86 & f3 & 2,40 & 2,60 & 2,60 & --- \\
\hline f4 & 3 & 2.86 & f4 & 2,40 & 2,60 & 2,60 & --- \\
\hline f5 & 3 & 1,74 & f5 & 1,70 & 2,20 & 2,20 & --- \\
\hline f6 & 3 & 2.86 & f6 & 1,70 & 2,20 & 2,20 & --- \\
\hline f7 & 3 & 3,62 & f7 & 2,30 & 2,40 & 2,40 & --- \\
\hline f8 & 3 & 1,74 & f8 & 1,70 & 2,20 & 2,20 & --- \\
\hline f9 & 3 & 2,70 & f9 & 2,30 & 2,20 & 2,20 & --- \\
\hline f10 & 3 & 3,62 & f10 & 2,30 & 2,20 & 2,20 & --- \\
\hline f11 & 3 & 2,86 & f11 & 2,30 & 2,20 & 2,20 & --- \\
\hline f12 & 3 & 2,70 & f12 & 2,30 & 2,20 & 2,20 & --- \\
\hline f13 & 3 & 2,86 & f13 & 2,30 & 2,20 & 2,20 & --- \\
\hline f14 & 3 & 2,86 & f14 & 2,30 & 2,20 & 2,20 & --- \\
\hline bc1 & \multicolumn{2}{|c|}{15} & bc1 $\left[{ }^{\circ} \mathrm{C}\right]$ & 15 & 15 & 15 & --- \\
\hline bc2 & \multicolumn{2}{|c|}{$16-35$} & bc2 $\left[{ }^{\circ} \mathrm{C}\right]$ & $18-32$ & $18-32$ & $18-32$ & --- \\
\hline bc3 & \multicolumn{2}{|c|}{--} & bc3 $\left[{ }^{\circ} \mathrm{C}\right]$ & --- & --- & --- & --- \\
\hline bc4 & \multicolumn{2}{|c|}{--} & bc4 $\left[{ }^{\circ} \mathrm{C}\right]$ & --- & --- & --- & --- \\
\hline bc5 & \multicolumn{2}{|c|}{11} & bc5 $\left[{ }^{\circ} \mathrm{C}\right]$ & 9 & 9 & 9 & --- \\
\hline bc6 & \multicolumn{2}{|c|}{18} & bc6 $\left[{ }^{\circ} \mathrm{C}\right]$ & 15 & 15 & 15 & --- \\
\hline bc7 & \multicolumn{2}{|c|}{$50 \mathrm{~mW} / \mathrm{m}^{2}$} & bc7 & $\begin{array}{c}\text { heatflux } \\
55 \mathrm{~mW} / \mathrm{m}^{2}\end{array}$ & $\begin{array}{c}\text { heatflux } \\
55 \mathrm{~mW} / \mathrm{m}^{2}\end{array}$ & $\begin{array}{c}\text { heatflux } \\
60 \mathrm{~mW} / \mathrm{m}^{2}\end{array}$ & $\begin{array}{c}\text { temp. at } 750 \\
\mathrm{~m} 30^{\circ} \mathrm{C} \\
\text { no data } \\
\text { below }\end{array}$ \\
\hline bc8 & \multicolumn{2}{|c|}{--} & bc8 & --- & --- & --- & (5) \\
\hline \multicolumn{3}{|c|}{ Observation points OP: } & \multicolumn{5}{|c|}{$\begin{array}{l}\text { numerical modeling results of temperature in observation points } \\
\text { (temperature calibration) in }\left[{ }^{\circ} \mathrm{C}\right] \text { : }\end{array}$} \\
\hline 1 & \multicolumn{2}{|l|}{ AIG10 spud in } & [ surface ] & --- & $\overline{---}$ & $\overline{---}$ & $\overline{---}$ \\
\hline 2 & \multicolumn{2}{|l|}{ seawater level } & {$[0 \mathrm{~m}]$} & --- & --- & --- & --- \\
\hline 3 & \multicolumn{2}{|l|}{ pumptest AIG10C } & {$[215 \mathrm{~m}]$} & 19,64 & 19,60 & 19,63 & 19,96 \\
\hline 4 & \multicolumn{2}{|l|}{ marine clay } & {$[450 \mathrm{~m}]$} & 26,15 & 25,81 & 25,88 & 24,78 \\
\hline 5 & \multicolumn{2}{|c|}{ limestones with radiolarite intercalations } & {$[540 \mathrm{~m}]$} & 28,08 & 27,67 & 27,74 & 27,11 \\
\hline 6 & \multicolumn{2}{|l|}{ radiolarites } & {$[635 \mathrm{~m}]$} & 29,36 & 29,07 & 29,18 & 28,82 \\
\hline 7 & \multicolumn{2}{|c|}{ pumptest AIG10L set point 5 bar } & {$[720 \mathrm{~m}]$} & 30,27 & 30,11 & 30,25 & 30,57 \\
\hline 8 & \multicolumn{2}{|c|}{ below Aigio fault; set point 10 bar } & {$[780 \mathrm{~m}]$} & 30,73 & 30,61 & 30,76 & $31.33(749 \mathrm{~m})$ \\
\hline 9 & \multicolumn{2}{|l|}{ borehole total Depth } & {$[1001 \mathrm{~m}]$} & 32,42 & 32,38 & 32,76 & --- \\
\hline 10 & \multicolumn{2}{|l|}{ total depth of model } & {$[1155 \mathrm{~m}]$} & 35,19 & 35,18 & 35,72 & --- \\
\hline
\end{tabular}


Tab. VII.9: Summary of values and starting conditions (left) for the numerical thermo-hydraulic model [B].

\begin{tabular}{|c|c|c|c|c|c|c|c|}
\hline Supermesh & $\begin{array}{l}\text { well log derived } \\
\text { porosity value [\%] } \\
\text { starting condition }\end{array}$ & $\begin{array}{c}\text { corrected thermal } \\
\text { conductivity } \\
\text { (matrix TC) } \\
\text { [W / m K] } \\
\text { starting condition } \\
\text { value }\end{array}$ & Supermesh & $\begin{array}{c}\text { [B]-1 } \\
{[\mathrm{W} / \mathrm{m} \mathrm{K}]}\end{array}$ & $\begin{array}{c}\text { [B]-2 } \\
{[\mathrm{W} / \mathrm{m} \mathrm{K}]}\end{array}$ & $\begin{array}{c}\text { [B]-3 } \\
{[\mathrm{W} / \mathrm{m} \mathrm{K}]}\end{array}$ & DTS Log \\
\hline Kf1 & 40 & 2.86 & Kf1 & 2,40 & 2,50 & 2,70 & --- \\
\hline Kf2 & 40 & 2.86 & Kf2 & 2,40 & 2,50 & 2,70 & --- \\
\hline Kf3a & 1.5 & 1.74 & Kf3a & 1,70 & 1,70 & 2,50 & --- \\
\hline Kf3b & 1.5 & 1.74 & Kf3b & 1,70 & 1,70 & 2,50 & --- \\
\hline Kf3c & 1.5 & 1.74 & Kf3c & 1,70 & 1,70 & 2,50 & --- \\
\hline Kf4 & 1.5 & 1.74 & Kf4 & 1,70 & 1,70 & 2,50 & --- \\
\hline Kf5 & 15 & 3.62 & Kf5 & 2,30 & 2,30 & 2,30 & --- \\
\hline Kf6 & 15 & 3.62 & Kf6 & 2,30 & 2,30 & 2,30 & --- \\
\hline Kf7 & 10 & 2.70 & Kf7 & 2,55 & 2,55 & 2,55 & --- \\
\hline Kf8 & 10 & 2.70 & Kf8 & 2,55 & 2,55 & 2,55 & --- \\
\hline Kf9 & 30 & 2.86 & Kf9 & 2,79 & 2,79 & 2,79 & --- \\
\hline Kf10 & 30 & 2.86 & Kf10 & 2,79 & 2,79 & 2,79 & --- \\
\hline Kf11 & 20 & 2.86 & Kf11 & 2,79 & 2,79 & 2,79 & --- \\
\hline Kf12 & 20 & 2.86 & Kf12 & 2,79 & 2,79 & 2,79 & --- \\
\hline f1 & 3 & 2.86 & f1 & 2,40 & 2,50 & 2,50 & $\overline{---}$ \\
\hline f2 & 3 & 2.86 & f2 & 2,40 & 2,50 & 2,50 & --- \\
\hline f3 & 3 & 2.86 & f3 & 2,40 & 2,50 & 2,50 & --- \\
\hline f4 & 3 & 2.86 & f4 & 2,40 & 2,50 & 2,50 & --- \\
\hline f5 & 3 & 1,74 & f5 & 1,70 & 2,50 & 2,50 & --- \\
\hline f6 & 3 & 2.86 & f6 & 1,70 & 1,70 & 1,70 & --- \\
\hline f7 & 3 & 3,62 & f7 & 2,30 & 2,30 & 2,30 & --- \\
\hline f8 & 3 & 1,74 & f8 & 1,70 & 1,70 & 1,70 & --- \\
\hline f9 & 3 & 2,70 & f9 & 2,30 & 2,30 & 2,30 & --- \\
\hline$f 10$ & 3 & 3,62 & f10 & 2,30 & 2,30 & 2,30 & --- \\
\hline f11 & 3 & 2,86 & f11 & 2,30 & 2,30 & 2,30 & --- \\
\hline f12 & 3 & 2,70 & f12 & 2,30 & 2,30 & 2,30 & --- \\
\hline f13 & 3 & 2,86 & f13 & 2,30 & 2,30 & 2,30 & --- \\
\hline f14 & 3 & 2,86 & f14 & 2,30 & 2,30 & 2,30 & --- \\
\hline \multicolumn{3}{|c|}{15} & bc1 $\left[{ }^{\circ} \mathrm{C}\right]$ & 15 & 17 & 17 & --- \\
\hline bc2 & \multicolumn{2}{|c|}{$\frac{15}{16-35}$} & bc2 $\left[{ }^{\circ} \mathrm{C}\right]$ & $18-32$ & $18-32$ & $18-32$ & --- \\
\hline bc3 & \multicolumn{2}{|c|}{--} & bc3 $\left[{ }^{\circ} \mathrm{C}\right]$ & --- & --- & --- & --- \\
\hline bc4 & \multicolumn{2}{|c|}{--} & bc4 $\left[{ }^{\circ} \mathrm{C}\right]$ & --- & --- & --- & --- \\
\hline bc5 & \multicolumn{2}{|c|}{11} & bc5 $\left[{ }^{\circ} \mathrm{C}\right]$ & 9 & 9 & 9 & --- \\
\hline bc6 & \multicolumn{2}{|c|}{18} & bc6 $\left[{ }^{\circ} \mathrm{C}\right]$ & 16 & 17 & 17 & --- \\
\hline bc7 & \multicolumn{2}{|c|}{$50 \mathrm{~mW} / \mathrm{m}^{2}$} & bc7 & $\begin{array}{l}\text { heatflux } \\
50 \mathrm{~mW} / \mathrm{m}^{2}\end{array}$ & $\begin{array}{l}\text { heatflux } \\
55 \mathrm{~mW} / \mathrm{m}^{2}\end{array}$ & $\begin{array}{c}\text { heatflux } \\
55 \mathrm{~mW} / \mathrm{m}^{2}\end{array}$ & $\begin{array}{c}\text { temp. at } 750 \\
\mathrm{~m} 30^{\circ} \mathrm{C} \\
\text { no data } \\
\text { below }\end{array}$ \\
\hline bc8 & \multicolumn{2}{|c|}{--} & bc8 & --- & --- & --- & --- \\
\hline \multicolumn{3}{|c|}{ Observation points OP: } & \multicolumn{5}{|c|}{$\begin{array}{l}\text { numerical modeling results of temperature in observation points } \\
\text { (temperature calibration) in }\left[{ }^{\circ} \mathrm{C}\right]:\end{array}$} \\
\hline 1 & \multicolumn{2}{|l|}{ AIG10 spud in } & [ surface ] & --- & --- & --- & --- \\
\hline 2 & \multicolumn{2}{|l|}{ seawater level } & {$[0 \mathrm{~m}]$} & --- & --- & --- & --- \\
\hline 3 & \multicolumn{2}{|l|}{ pumptest AIG10C } & {$[215 \mathrm{~m}]$} & 17,67 & 19,27 & 19,26 & 19,96 \\
\hline 4 & \multicolumn{2}{|l|}{ marine clay } & {$[450 \mathrm{~m}]$} & 26,12 & 26,87 & 26,33 & 24,78 \\
\hline 5 & \multicolumn{2}{|c|}{ limestones with radiolarite intercalations } & {$[540 \mathrm{~m}]$} & 29,05 & 29,61 & 28,89 & 27,11 \\
\hline 6 & \multicolumn{2}{|l|}{ radiolarites } & {$[635 \mathrm{~m}]$} & 30,73 & 31,20 & 30,79 & 28,82 \\
\hline 7 & \multicolumn{2}{|c|}{ pumptest AIG10L set point 5 bar } & {$[720 \mathrm{~m}]$} & 31,56 & 32,00 & 31,74 & 30,57 \\
\hline 8 & \multicolumn{2}{|c|}{ below Aigio fault; set point 10 bar } & {$[780 \mathrm{~m}]$} & 32,06 & 32,50 & 32,31 & $31.33(749 \mathrm{~m})$ \\
\hline 9 & \multicolumn{2}{|l|}{ borehole total Depth } & {$[1001 \mathrm{~m}]$} & 34,02 & 34,54 & 34,47 & --- \\
\hline 10 & \multicolumn{2}{|l|}{ total depth of model } & {$[1155 \mathrm{~m}]$} & 36,74 & 37,49 & 37,46 & --- \\
\hline
\end{tabular}


Tab. VII.10: Summary of values and starting conditions (left) for the numerical thermo-hydraulic model [C].

\begin{tabular}{|c|c|c|c|c|c|c|c|c|c|}
\hline Supermesh & $\begin{array}{c}\text { well log } \\
\text { derived } \\
\text { porosity } \\
\text { value [\%] } \\
\text { starting } \\
\text { condition }\end{array}$ & $\begin{array}{c}\text { corrected } \\
\text { thermal } \\
\text { conductivity } \\
\text { (matrix TC) } \\
{[\mathrm{W} / \mathrm{m} \mathrm{K}]} \\
\text { starting } \\
\text { condition } \\
\text { value }\end{array}$ & $\begin{array}{l}\text { thermal } \\
\text { conductivity } \\
\text { adjusted to } \\
\text { well log } \\
\text { porosity } \\
\text { [W/m K] } \\
\text { expected } \\
\text { values }\end{array}$ & Supermesh & $\begin{array}{c}{[\mathrm{C}]-1} \\
{[\mathrm{~W} / \mathrm{m} \mathrm{K}]}\end{array}$ & $\begin{array}{c}{[\mathrm{C}]-2} \\
{[\mathrm{~W} / \mathrm{m} \mathrm{K}]}\end{array}$ & $\begin{array}{c}{[\mathrm{C}]-3} \\
{[\mathrm{~W} / \mathrm{m} \mathrm{K}]}\end{array}$ & $\begin{array}{c}{[\mathrm{C}]-4} \\
{[\mathrm{~W} / \mathrm{m} \mathrm{K}]}\end{array}$ & DTS Log \\
\hline Kf1 & 40 & 2.86 & \multirow{2}{*}{1.53} & Kf1 & 2,40 & 1,50 & 2,30 & 2,30 & $\overline{---}$ \\
\hline Kf2 & 40 & 2.86 & & Kf2 & 2,40 & 1,50 & 2,30 & 2,30 & --- \\
\hline Kf3a & 1.5 & 1.74 & \multirow{4}{*}{1.71} & Kf3a & 1,70 & 1,70 & 2,00 & 2,00 & --- \\
\hline Kf3b & 1.5 & 1.74 & & Kf3b & 1,70 & 1,70 & 1,70 & 1,70 & --- \\
\hline Kf3c & 1.5 & 1.74 & & Kf3c & 1,70 & 1,70 & 1,70 & 1,70 & --- \\
\hline Kf4 & 1.5 & 1.74 & & Kf4 & 1,70 & 1,70 & 1,70 & 1,70 & --- \\
\hline Kf5 & 15 & 3.62 & \multirow{2}{*}{2.77} & Kf5 & 2,30 & 2,30 & 2,30 & 2,30 & --- \\
\hline Kf6 & 15 & 3.62 & & Kf6 & 2,30 & 2,30 & 2,30 & 2,30 & --- \\
\hline Kf7 & 10 & 2.70 & \multirow{2}{*}{2.32} & Kf7 & 2,55 & 2,55 & 2,55 & 2,55 & --- \\
\hline Kf8 & 10 & 2.70 & & Kf8 & 2,55 & 2,55 & 2,55 & 2,55 & --- \\
\hline Kf9 & 30 & 2.86 & \multirow{4}{*}{2.09} & Kf9 & 2,79 & 2,79 & 2,79 & 2,79 & --- \\
\hline Kf10 & 30 & 2.86 & & Kf10 & 2,79 & 2,79 & 2,79 & 2,79 & --- \\
\hline Kf11 & 20 & 2.86 & & Kf11 & 2,79 & 2,79 & 2,79 & 2,79 & --- \\
\hline Kf12 & 20 & 2.86 & & Kf12 & 2,79 & 2,79 & 2,79 & 2,79 & --- \\
\hline f1 & 3 & 2.86 & --- & $f 1$ & 2,40 & 150 & 2,00 & 2,00 & --- \\
\hline f2 & 3 & 2.86 & --- & f2 & 2,40 & 1,50 & 2,00 & 2,00 & --- \\
\hline f3 & 3 & 2.86 & --- & f3 & 2,40 & 1,50 & 2,00 & 2,00 & --- \\
\hline f4 & 3 & 2.86 & --- & f4 & 2,40 & 1,50 & 2,00 & 2,00 & --- \\
\hline f5 & 3 & 1,74 & --- & f5 & 1,70 & 2,50 & 2,00 & 2,00 & --- \\
\hline f6 & 3 & 2.86 & --- & f6 & 1,70 & 1,70 & 2,00 & 2,00 & --- \\
\hline f7 & 3 & 3,62 & --- & f7 & 2,30 & 2,30 & 2,00 & 2,00 & --- \\
\hline f8 & 3 & 1,74 & --- & f8 & 1,70 & 1,70 & 2,00 & 2,00 & --- \\
\hline f9 & 3 & 2,70 & --- & f9 & 2,30 & 2,30 & 2,30 & 2,30 & --- \\
\hline f10 & 3 & 3,62 & --- & f10 & 2,30 & 2,30 & 2,30 & 2,30 & --- \\
\hline f11 & 3 & 2,86 & --- & f11 & 2,30 & 2,30 & 2,30 & 2,30 & --- \\
\hline f12 & 3 & 2,70 & --- & f12 & 2,30 & 2,30 & 2,30 & 2,30 & --- \\
\hline f13 & 3 & 2,86 & --- & f13 & 2,30 & 2,30 & 2,30 & 2,30 & --- \\
\hline \multirow[t]{2}{*}{ f14 } & 3 & 2,86 & --- & f14 & 2,30 & 2,30 & 2,30 & 2,30 & --- \\
\hline & & & & & & & & & \\
\hline bc1 & & 15 & & bc1 $\left[{ }^{\circ} \mathrm{C}\right]$ & 17 & $15-17$ & $17-20$ & $17-18$ & --- \\
\hline bc2 & & $16-35$ & & bc2 $\left[{ }^{\circ} \mathrm{C}\right]$ & $18-32$ & $18-32$ & $18-32$ & $18-32$ & --- \\
\hline bc3 & & -- & & bc3 $\left[{ }^{\circ} \mathrm{C}\right]$ & --- & --- & --- & --- & --- \\
\hline bc4 & & -- & & bc4 $\left[{ }^{\circ} \mathrm{C}\right]$ & --- & --- & --- & --- & --- \\
\hline bc5 & & 11 & & bc5 $\left[{ }^{\circ} \mathrm{C}\right]$ & 9 & 10 & 10 & 10 & --- \\
\hline bc6 & & 18 & & bc6 $\left[{ }^{\circ} \mathrm{C}\right]$ & 17 & 15 & 15 & 16 & --- \\
\hline bc7 & \multicolumn{3}{|c|}{$50 \mathrm{~mW} / \mathrm{m}^{2}$} & bc7 & $\begin{array}{l}\text { heatflux } \\
40 \mathrm{~mW} / \mathrm{m}^{2}\end{array}$ & $\begin{array}{c}\text { heatflux } \\
50 \mathrm{~mW} / \mathrm{m}^{2}\end{array}$ & $\begin{array}{l}\text { heatflux } \\
60 \mathrm{~mW} / \mathrm{m}^{2}\end{array}$ & $\begin{array}{c}\text { heatflux } \\
55 \mathrm{~mW} / \mathrm{m}^{2}\end{array}$ & --- \\
\hline bc8 & \multicolumn{3}{|c|}{---} & bc8 & --- & --- & --- & --- & --- \\
\hline \multicolumn{4}{|c|}{ Observation points OP: } & \multicolumn{5}{|c|}{$\begin{array}{l}\text { numerical modeling results of temperature in observation points } \\
\text { (temperature calibration) in }\left[{ }^{\circ} \mathrm{C}\right]:\end{array}$} & \\
\hline 1 & \multicolumn{3}{|c|}{ AIG10 spud in } & [ surface ] & --- & --- & $\overline{---}$ & $\overline{---}$ & $\overline{---}$ \\
\hline 2 & \multicolumn{3}{|c|}{ seawater level } & {$[0 \mathrm{~m}]$} & --- & --- & --- & --- & --- \\
\hline 3 & \multicolumn{3}{|c|}{ pumptest AIG10C } & [ $215 \mathrm{~m}]$ & 19,40 & 19,08 & 21,14 & 20,01 & 19,96 \\
\hline 4 & \multicolumn{3}{|c|}{ marine clay } & {$[450 \mathrm{~m}]$} & 23,59 & 24,41 & 25,54 & 24,54 & 24,78 \\
\hline 5 & \multicolumn{3}{|c|}{ limestones with radiolarite intercalations } & {$[540 \mathrm{~m}]$} & 25,72 & 26,67 & 27,73 & 26,77 & 27,11 \\
\hline 6 & \multicolumn{3}{|c|}{ radiolarites } & {$[635 \mathrm{~m}]$} & 27,56 & 28,63 & 29,82 & 28,88 & 28,82 \\
\hline 7 & \multicolumn{3}{|c|}{ pumptest AIG10L set point 5 bar } & {$[720 \mathrm{~m}]$} & 29,06 & 30,23 & 31,52 & 30,60 & 30,57 \\
\hline 8 & \multicolumn{3}{|c|}{ below Aigio fault; set point 10 bar } & {$[780 \mathrm{~m}]$} & 30,00 & 31,25 & 32,64 & 31,73 & $31,33(749 \mathrm{~m})$ \\
\hline 9 & borehole tot & Depth & & {$[1001 \mathrm{~m}]$} & 33,27 & 34,90 & 36,57 & 35,67 & 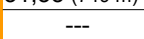 \\
\hline 10 & total depth & model & & {$[1155 \mathrm{~m}]$} & 36,06 & 38,22 & 40,42 & 39,29 & --- \\
\hline
\end{tabular}




\section{VII.5.4 Discussion}

The coupling of temperature, geothermal and hydraulic parameters in the models $[\mathrm{A}],[\mathrm{B}]$, and $[\mathrm{C}]$ has shown, that only version [C] is able to reproduce the measured DTS values. The attached thermal conductivities of the lithological formations are in good correlation with the values derived from laboratory measurements corrected for the in-situ porosity. The heat flow boundary, producing the best data fit is $55 \mathrm{~mW} / \mathrm{m}^{2}$ which is close to the average heat flow $\left(50.5 \mathrm{~mW} / \mathrm{m}^{2}\right)$ calculated from four different depth intervals in AIG10.

However, the interval values differ in a large range $\left(42-60 \mathrm{~mW} / \mathrm{m}^{2}\right)$. There are two ways to explain the large range in values. One explanation would be that we have a conduction-dominated thermal regime along the depth profile and the differences in heat flow is entirely the result of not having picked properly the in situ thermal conductivity for some intervals. Another explanation would be that some of the intervals are affected by heat advection due to fluid flow affecting the temperature gradient and hence the heat flow. The background knowledge of hydrogeological features suggests the latter condition.

Fig. VII.15 shows the streamlines of the model [C]-4 in the domain of the Aigion normal fault.

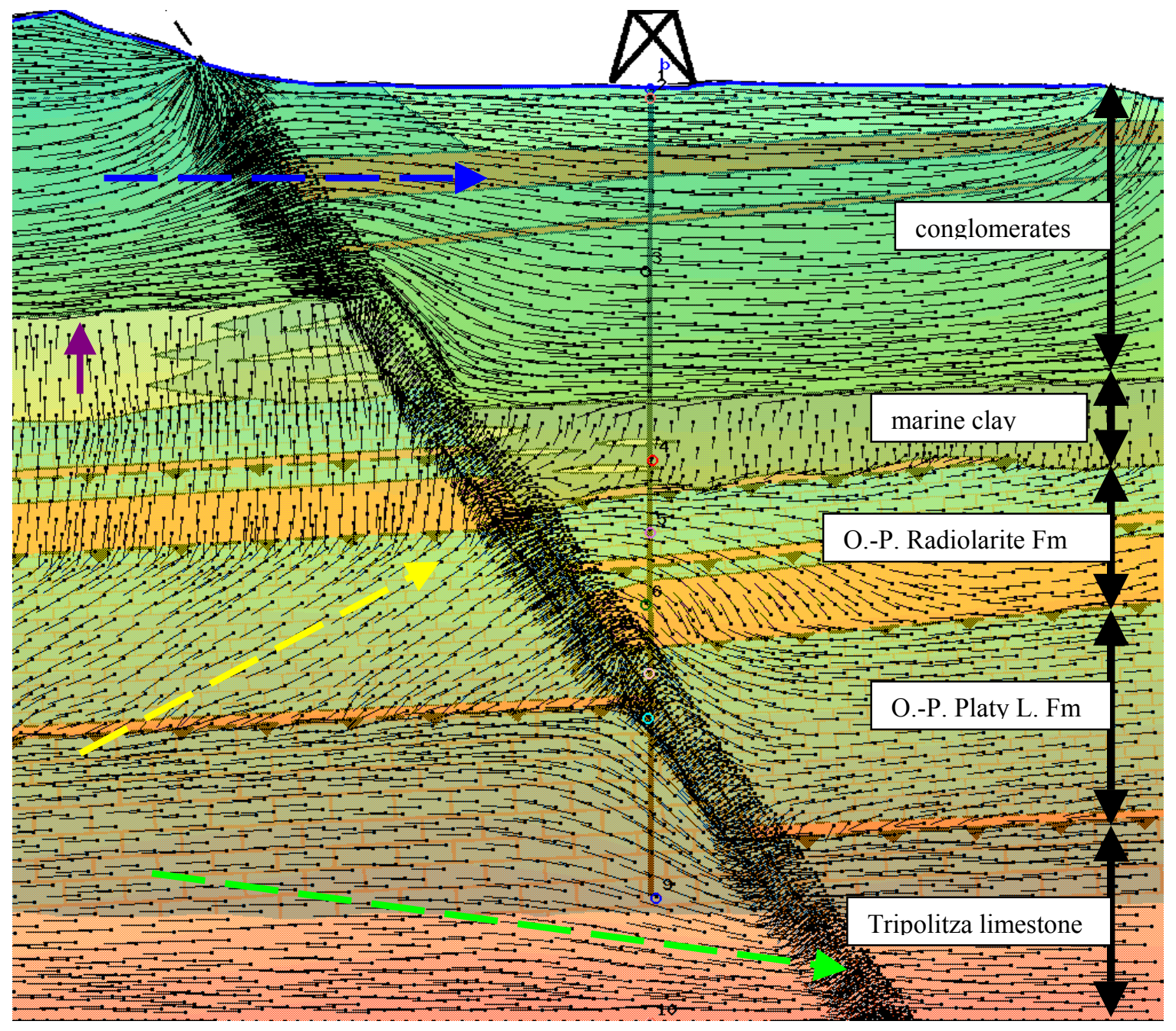

Fig. VII.15: Streamlines of the model scenario [C]-4 in the domain of the Aigion fault (explanations see text). 
Fluid flow is especially high in the conglomerate interval, which could result in a lowering of the temperature gradient and heat flow (blue arrow). The interval with the marine to lagoonal sediments acts more or less as an aquitard. Most likely this interval is not affected by fluid flow and the heat flow determined in this interval is assumed to be more or less conductive $\left(50 \mathrm{~mW} / \mathrm{m}^{2}\right.$, Tab. VII.10), perhaps resembling the conductive heat flow from larger depth for the AIG10 site (violet arrow). The higher heat flow of $60 \mathrm{~mW} / \mathrm{m}^{2}$ in the platy limestones could be because of upstreaming water bringing warmer temperature from greater depth to the interval (yellow arrow). Fluid flow is high in the Tripolitza limestones with high karstification. This could result in a lowering of the temperature gradient and heat flow (green arrow) before reaching the fault plane.

The temperature distribution is displayed in Fig. VII.16. Resembling the conceptual model and the numerical hydraulic flow model the figure show two separated hydraulic systems.

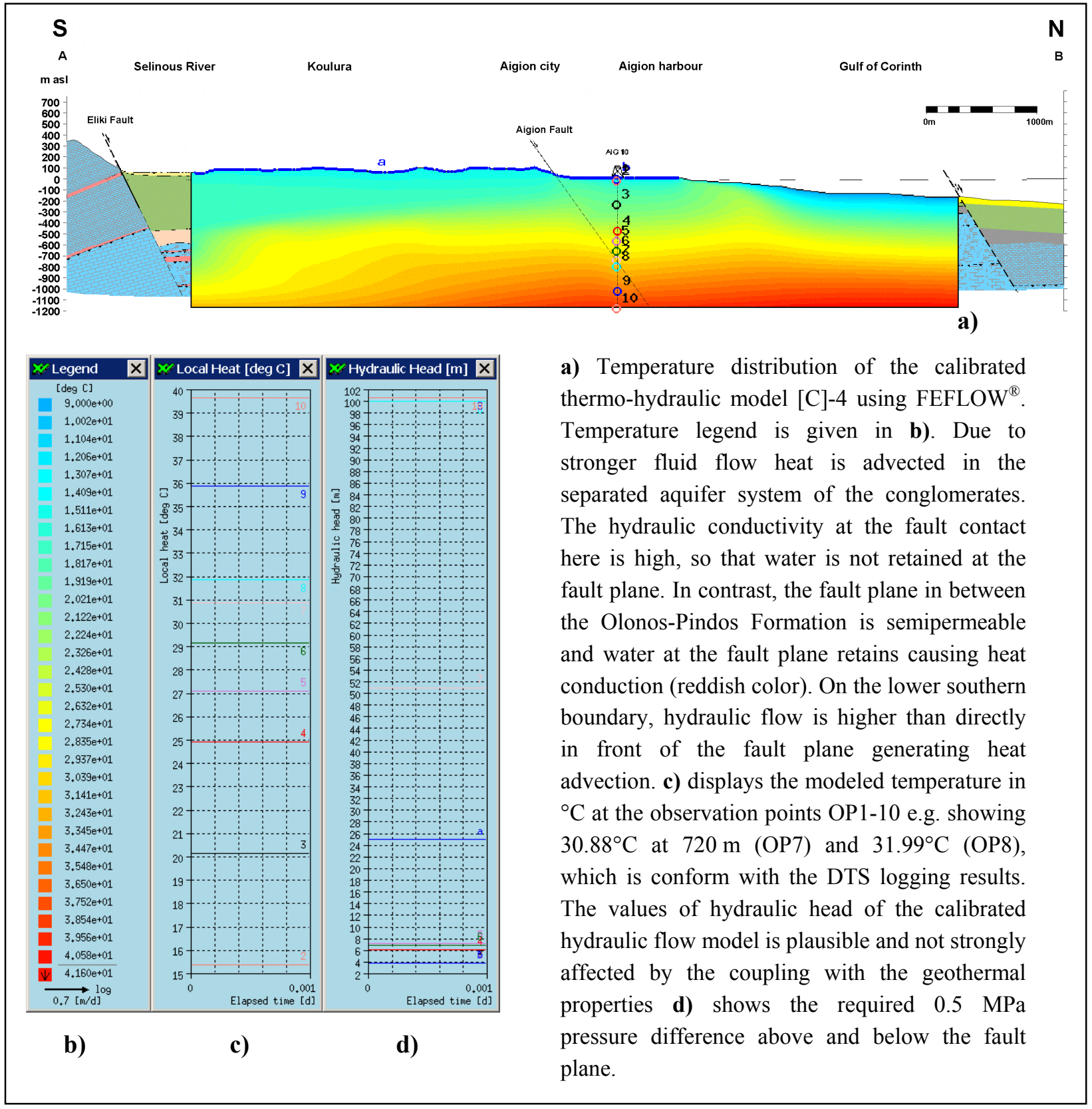

Fig. VII.16: Results and temperature distribution of the calibrated thermo-hydraulic model [C]-4. 
The lacustrine-lagoonal sandy clays act as vertical hydraulic barriers and are not affected by strong fluid flow. They separate the conglomerates above from the Olonos-Pindos Formation below. A lowering of the temperature gradient and heat flow in the conglomerate aquifer is visible in the temperature distribution (Fig. VII.16). The higher hydraulic conductivity of the conglomerates and the fault contact causes continuous fluid flow and no water retaining at the fault plane. Therefore it is supposed, that heat is advected in the separated aquifer system of the conglomerates.

Fluid flow is also high at the southern lower boundary bc1, which results in lower temperatures at the fluid entrance as long as the flow is not retained at the semipermeable fault plane in the platy limestones (Fig. VII.16). The water retained at the fault plane is exposed in a rising temperature gradient because of causing heat conduction, visible by a temperature bulk in the footwall of the Aigion fault.

In contrast, the fault plane itself is expressed in a lowering of temperature gradient because of up streaming and down streaming fluid, parallel along the plane as discussed in the conceptual model. The convective influence to the heat after passing the fault plane at $760 \mathrm{~m}$ is still remarkable in OP9 at $1000 \mathrm{~m}$ depth. It is supposed, like mentioned in the conceptual model, that the downwards forced water flow from the Olonos-Pindos Formation along the fault plane to the karstified Tripolitza limestones affecting the temperature gradient by heat advection. On the other hand Fig. VII.16 confirms, that, to the south of the foot wall, upstreaming warmer water from depth is resulting in higher temperatures (yellow arrow in Fig. VII.15). The temperature distribution therefore has confirmed and quantified further assumptions that some of intervals are affected by fluid flow causing heat advection and influence the heat flow and the temperature gradient.

If the thermo-hydraulic system is affected by fluid flow it is now of interest to show how the temperature would be under pure conduction conditions. To prepare this scenario [D] a model run on the base of the calibrated scenario [C]-4 is performed assuming no hydraulic flow in the system. The blue line in Fig. VII.17 shows the resulting geothermal profile correlated to [C]-4 and the DTS log. Temperature increases to $36.20{ }^{\circ} \mathrm{C}$ at $745 \mathrm{~m}$ (DTS total depth) and up to $41.19{ }^{\circ} \mathrm{C}$ at $1001 \mathrm{~m}$ (AIG10 total depth) and $44.74^{\circ} \mathrm{C}$ at the lower model boundary bc7 $(1155 \mathrm{~m})$. At latter depth, the temperature difference is approximately $5.5^{\circ} \mathrm{C}$ higher in respect of the coupled thermo-hydraulic flow model.

The comparison of the observation points 1-10 of [C]-4 are matching very good to the temperature values picked from the DTS log (Fig. VII.18). The local temperatures in the observation points of [D] show higher temperatures in all points. The table below highlights the differences in temperatures. 


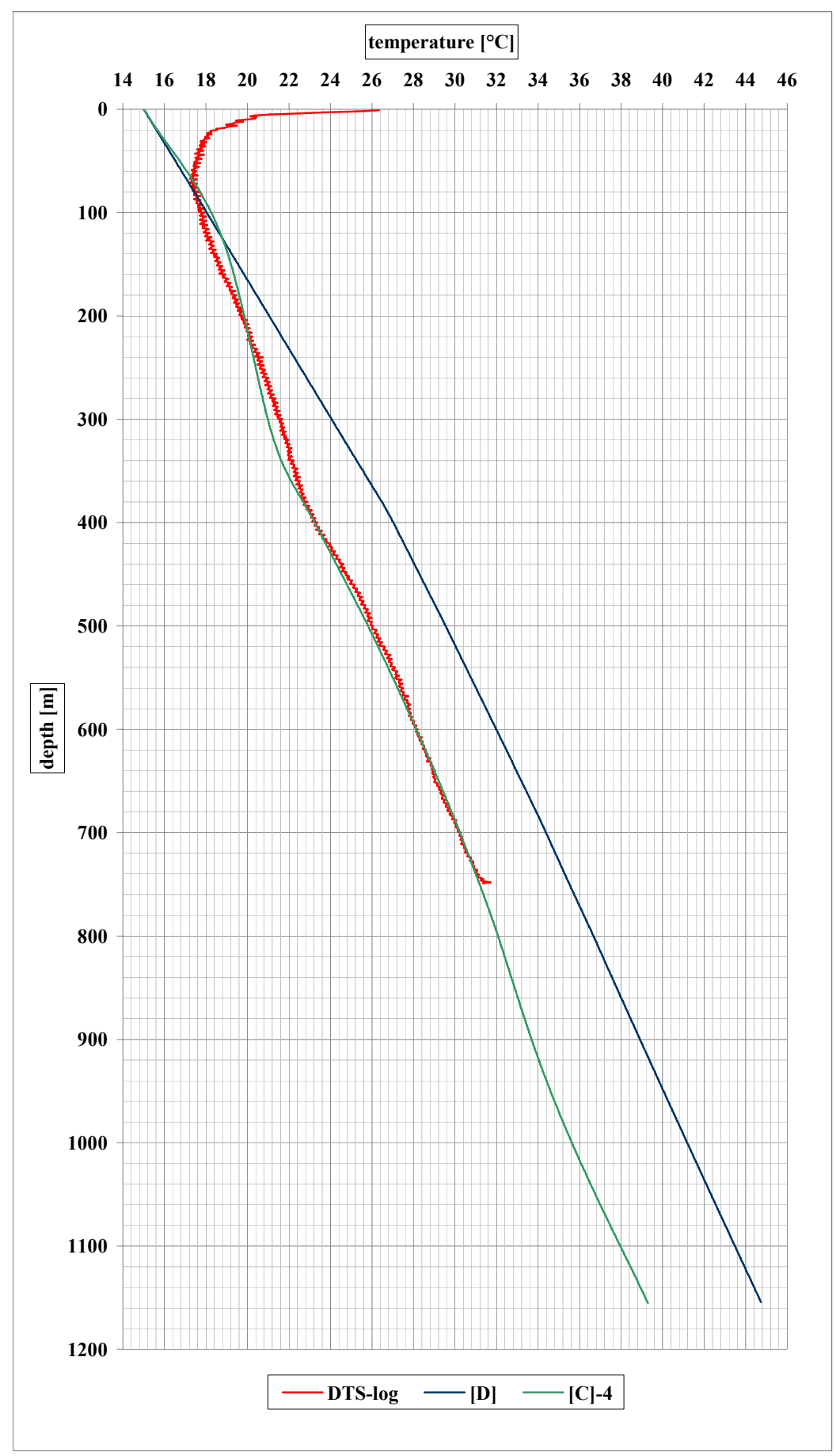

Fig. VII.17: Modeled temperature profiles of [C]-4 and [D] vs. DTS-log. The well calibrated coupled thermohydraulic version [C] (green) corresponds good to the DTS geothermal profile (red). The blue graph [D] show the temperature curve when hydraulic flow conditions are set to zero giving pure conduction conditions (hydraulic head $=0 ; \mathrm{bc} 1, \mathrm{bc} 2, \mathrm{bc} 3, \mathrm{bc} 4, \mathrm{bc} 5=0$; no flow). At the lowermost model boundary temperature is approx. $4.5^{\circ} \mathrm{C}$ higher than in the calibrated coupled thermo-hydraulic numerical model with hydraulic flow. 


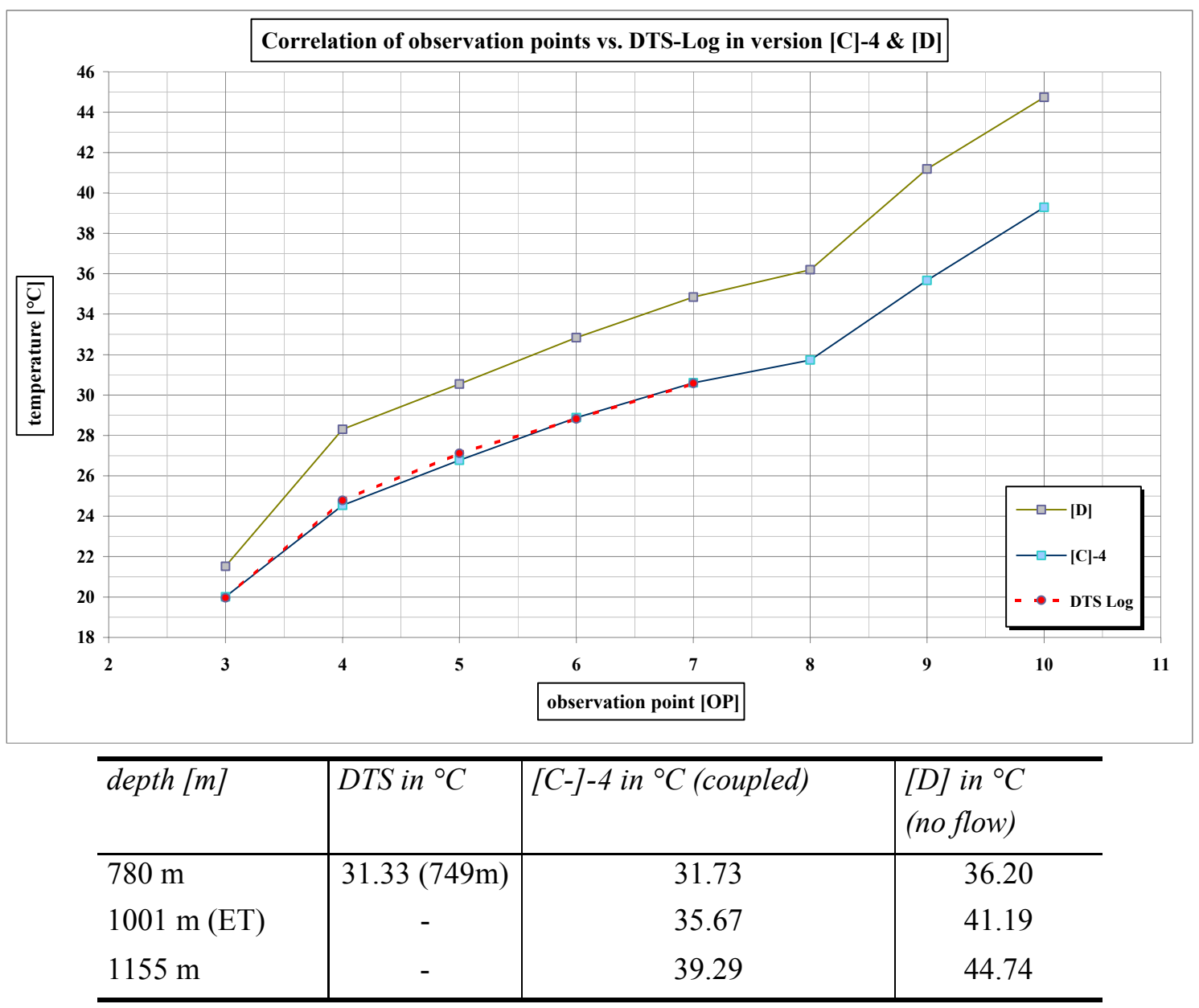

Fig. VII.18: Correlation of observation points from model scenario [C]-4 with the scenario [D] in respect of no hydraulic flow conditions and DTS-log. Thermal parameters such as heat flow is unchanged in the model [D]. 


\section{Summary}

This study is aimed at the exploration of the thermo-hydraulic conditions in the case of the Gulf of Corinth rift representing an active seismically zone. The study would not have been completed successfully, if the basic field work, in an area devoid of a geological map, would not have been conducted. The results gained from field mapping during the project were crucial for the final aim of the study, but in addition substantially supported by the drilling of the ICDP-AIG10 borehole.

A widespread area of the Peloponnesus peninsula and the southern Corinth graben shoulder in the vicinity of Aigion belongs to the Olonos-Pindos thrust nappe and is characterized by thrust faults and normal faults. The extensional process of the Gulf is mainly accomplished by WNW-trending active onshore and offshore faults. Five major faults were known to be most responsible for the historic and present seismic activities at the study area in the vicinity of Aigion and a sixth normal fault "Ponti" is newly discovered within this work. These E-W striking normal faults, related to the Miocene Holocene rifting of the Golf of Corinth are younger than the tectonical structures of the Alpine orogeny. The orogenic overthrusting within the Olonos-Pindos Formation is very pronounced and is frequently leading to multiple imbrication and stratigraphic repetitions. These repetitions were additionally block-faulted by the neotectonics of the Corinth Rift. A geological-tectonical map in an area of $80 \mathrm{~km}^{2}$ is now available for the larger Aigion region. This map is accompanied by several geological cross sections showing the complex coherences between the Alpidic structures and the younger structures developed during the extension of the Gulf of Corinth. A $22 \mathrm{~km} \mathrm{N-S}$ cross section has formed an ideal basis for the compilation of a hydrogeological conceptual model and for the definition of the model architecture. The understanding of the complex tectonical structure was a key for planning and supporting the drilling activities and for interpreting the succession in the AIG10 borehole.

In general the hydraulic system is well developed at the southern graben shoulder and at depth one may reckon karst conditions especially where Tripolitza limestone is prevailing. The lithological horizontal transition from the Tripolitza to the Olonos-Pindos Formation, marine-lagoonal sedimentation and Delta conglomerates causes in different developed hydraulic systems, which are separated and are in general of only little or no association with each other. In addition, the very complex geological-tectonical structure of the area leads to strong heterogeneities in between the units.

It was shown that fault zones can exhibit a high degree of gradual segmentation. Occasionally, the fault zones within the conglomerates and other rift sediments reaches a thickness of several hundred meters and are characterized by parallel syn- and antithetic normal faults. In contrast, the Mesozoic Olonos-Pindos Formation show a different behavior when affected by normal faulting. It is concluded that the fault zones in the Olonos-Pindos Formation seem to act as a extremely low permeable/semipermeable sequences or even as hydraulic barriers, which is confirmed by pumping tests. Evidence is given also by a pressure gradient of $7.813 \times 10-3 \mathrm{MPa} / \mathrm{m}$ in the depth interval of $708 \mathrm{~m}$ (hangingwall; 0,5 MPa) and $772 \mathrm{~m}$ (foot wall; $1 \mathrm{MPa}$ ) which are one of the most important parameters to calibrate the hydrogeological numerical flow model. The formation water of both, the platy limestones and the Tripolitza limestones possesses no marine influence and is recharged in the hinterland. 
Geophysical logging was of great use for refining the litho-log from the cutting and core analysis by the graphical treatment of the recorded data. The quantitative petrophysical analysis was made using statistical methods of $\log$ analysis. Estimates of porosity and permeability as well as of compositional data were derived for intervals in the litho-log. Average total porosities are estimated for the different lithological units.

Temperature logging performed in the AIG10 borehole one year after drilling provided subsurface conditions not affected by drilling or artesian flow. However, as a result of relative movements along the Aigion fault plane in $760 \mathrm{~m}$ depth the borehole was blocked at the time of logging in the deeper part of the borehole. A temperature profile below the Aigion fault could not be retrieved, which affected slightly the overall project goals. Thus, the interval of 750-1000 $\mathrm{m}$ had to develop through the numerical model without having any temperature constraint available.

In the temperature-logged interval of AIG10, the temperature gradient vs. depth pattern resembles much of the change in lithological formations. This was confirmed by the laboratory-derived thermal conductivity for major rock types. Based on temperature gradients calculated for 1-m depth intervals, heat flow then was determined for larger discrete depth intervals according to Fourier's law of heat conduction and then averaged over the length of the borehole. The heat-flow intervals were selected from a joint analysis of the petrophysical and thermal well logs. Some variability in the interval heat flow was observed that may originate from the lithological complexity and the therewith-related uncertainties in calculation of the formation thermal conductivity. To quantify how much of the signal is by heat advection/fluid flow numerical modeling was performed.

The coupling of temperature and geothermal parameters to the calibrated hydraulic flow model versions has shown, that the hydrogeological conceptual model could be converted in a successful way. A model version is generated where it was able to calibrate the coupled model results to the measured DTS values while the calibration parameters of the hydraulic flow stay stable. The attached thermal conductivities on the lithological formations are in good correlation with the values derived from laboratory measurements. The examination of modeling runs with heat flow boundary conditions between $40 \mathrm{~mW} / \mathrm{m}^{2}$ and $60 \mathrm{~mW} / \mathrm{m}^{2}$ has shown that heat flow from depth is about $55 \mathrm{~mW} / \mathrm{m}^{2}$ witch is relatively conform with the average heat flow of $50.5 \mathrm{~mW} / \mathrm{m}^{2}$ for the AIG10 site calculated from four different depth intervals. The interval values differ largely giving rise to a large standard deviation $(41.8-60 \mathrm{~mW} / \mathrm{m} 2)$. The explanation is that some of the intervals are affected by heat advection due to fluid flow affecting the temperature gradient and hence the heat flow.

Resembling the conceptual model the numerical thermo-hydraulic flow model show two separated hydraulic systems. Underlying lacustrine-lagoonal sandy clays, acting as vertical hydraulic barriers and not affected by fluid flow, separates the conglomerates above from the Olonos-Pindos Formation below which is visible in the lowering of the temperature gradient and heat flow at the top model domain. Fluid flow then is also high at the southern lower boundary, which results in lower temperatures at the fluid entrance as long as the flow is not retained at the semipermeable fault plane in between the platy limestones. Here temperature is rising up just before the fault plane. The fault plane itself is expressed in a lowering of temperature gradient because of up streaming and down streaming fluid along the semipermeable plane. It is supposed that the downwards forced water flow from the Olonos-Pindos Formation along the fault plane to the karstified Tripolitza limestones affecting the temperature gradient by heat advection. The temperature distribution therefore has 
confirmed and quantified intervals which are affected by fluid flow causing heat advection and influence the heat flow and the temperature gradient.

Assuming pure conduction conditions and no hydraulic flow in the system let the temperature increase to $35^{\circ} \mathrm{C}$ in $745 \mathrm{~m}$ up to $44.4^{\circ} \mathrm{C}$ at the lower model boundary. Here temperature difference is approximately $4.5^{\circ} \mathrm{C}$ higher in respect of the coupled thermo-hydraulic flow model.

It can be stated that the temperature field at Aigion is suppressed by the hydraulic conditions. The existence of the hydraulic field make a delamination of undisturbed crustal heat conduction and heat flow difficult. The results obtained at shallow depth are perturbed by the flow field. The best interval which was close to non-perturbed conditions is the interval from $380 \mathrm{~m}$ to $740 \mathrm{~m}$ where temperature gradients are mostly the same than measured by DTS.

Studying heat flow is essential for the knowledge of the thermal and rheological properties of the crust. It requires deep boreholes and a thorough investigation of the types of heat transfer. The Aigion study shows that fault zones may act as hydraulic barriers, separating fluid compartments of different hydraulic pressure. It is well established that the focal-depth distribution of earthquakes is an indicator of strength, or effective elastic thickness of the lithosphere. The concentration of seismicity in the continental crust (commonly restricted to depths shallower than about $20 \mathrm{~km}$ ) and correlation of maximum focal depth with surface heat flow suggest that temperature is one main control of strength. For this reason it is necessary to have an estimate about the temperature versus depth relation and heat flow. Thus, for properly assessing temperature at depth, data on surface heat flow, together with some estimate on crustal composition, especially on thermal rock properties, are essential. For future studies, long-term borehole observations of temperature, fluid flow, and seismicity would provide additional clues on the fault dynamics in the Corinthian seismogenic zone. Furthermore, in a 2-D model the lateral examination of geology and tectonics remain out of consideration. Thus, in a next step the extraction of the 2-D model to a 3-D model can be recommended.

Finally, it is clear that the quality of input data is playing a major role for the best fit of a numerical model. Otherwise it is also shown that very detailed processing of data could not be considered due to general restrictions required from the modeling software and therefore generalization is necessary. Undoubtedly, the fault zones of the Gulf of Corinth are representing one case of seismic zones and similar model approaches can be extended to other thermo-hydraulic systems with similar tectonical arrangements. 


\section{Bibliography}

Aeschbach-Hertig, W., Schlosser, P., Stute, M., Simpson, H. J., Ludin, A. \& Clark, J. F., 1998. A $3 \mathrm{H} / 3 \mathrm{He}$ study of groundwater flow in a fractured bedrock aquifer. Ground Water 36: 661-670.

Anderson, M.P. \& Woessner, W.W., 1992. Applied Groundwater Modeling: Simulation of Flow and Advective Transport. 381 p., Academic Press, San Diego.

Ambraseys, N.N., Jackson, J.A., 1997. Seismicity and strain in the Gulf of Corinth (Greece) since 1694. Journal of Earthquake Engineering 1, 433-474.

Armijo, R. et al., 1999. Westward propagation of the North Anatolian fault into the northern Aegean: Timing and kinematics. Geology, Vol. 27, No.3, p. 267-270.

Armijo, R., Meyer, B., King, G.C.P., Rigo, A. \& Papanastassiou, D., 1996. Quaternary evolution of the Corinth Rift and its implications for the late Cenozoic evolution of the Aegean. Geophys.J.Int., 126, 11-53.

Aubouin, J., 1959. Contribution à l'étude geologique de la Grèce septentrionale: le confins de l'Epire et de la Thessalie. Ann.Géol.Pays héllen, 10, 1-484.

Aubouin, J., Bonneau, M., Celet, P., Charvet, J. et al. 1970. Contribution à la géologie des Hellénide de Gavrovo, le Pinde et la zone ophiolothique subpélagonienne. Ann. Soc. Géol. Nord, Vol. 90, p. 277-306.

Aubouin, J., Desprairies, A. \& Therry, J., 1977. Le géosynclinal d'Epire-Akarnanie, la nappe de Pinde-Olonos et la nappe ophiolithique. Bull. Soc. Géol. France, (VII), Vol. 19, p. 20-27.

Bauer, E., 2004. Europäische Erdbebenzone Golf von Korinth: Geologisch-hydro-geologische Untersuchungen in der Region Aigion im Umfeld der Kontinentalen Tiefbohrung AIG10 (NW-Peleponnes, Griechenland). Unpubl. Diploma Thesis, Dept. of Applied Geology, University of Karlsruhe, 160 pp.

Bender, F., 1984. Angewandte Geowissenschaften. Methoden der Hydrogeologie, Bd. 3, 213-366, 106 Abb., Stuttgart.

Billiris, H., Paradissis, D., Veis, G., England, P., Featherstone, W., Parsons, B., Cross, P., Rands, P., Rayson, M., Sellers, P., Ashkenazi, V., Davison, M., Jackson, J.\& Ambraseys, N., 1991. Geodetic determination of tectonic deformation in Central Greece from 1900 to 1988. Nature 350, 124-129.

Bonneau, M., 1984. Correlation of the Hellenide nappes in the south-east Aegean and their tectonic reconstruction. In: Dixon JE, Robertson AHF (eds) The geological evolution of the eastern Mediterranean. Geol Soc Lond Spec Publ 17:517-527.

Briole, A., Rigo, A., Lyon-Caen, H., Ruegg, J.C., Papazissi, K., Mitsataki, C., Badolimou, A., Veis, G., Hatzfeld, D.\& Deschamps, A., 2000. Active deformation of the Corinth Rift, Greece: results from repeated global positioning system surveys between 1990 and 1995. J.Geophys.Res. 105, 25605-25626.

Brooks, M. \& Ferentinos, G., 1984. Tectonics and sedimentation in the Gulf of Corinth and the Zakynthos and Kefallinia channels, western Greece. Tectonophysics, Vol.101, No. 1-2, 25-54, Amsterdam.

Brune, J.N.,1968. Seismic moment, seismicity, and rate of slip along major fault zones. J. Geophys. Res. 73, p. 777-784. 
Chen, W. \& Molnar, P., 1983. Focal depths of intracontinental earthquakes and intraplate earthquakes and their correlations with heat flow and tectonic age. J. Geophys. Res., 88, 4183-4214.

Clément, C., Sachpazi, M., Charvis, P., Graindorge, D., Laigle, M., Hirn, A. \& Zafiropoulous, G., 2004. Reflection-refraction seismic in the Gulf of Corinth: hints at deep structure and control of the deep marine basin. Tectonophysics 391, 97-108.

Cooper, H.H. \& Jacob, C.E., 1946. A generalised graphical method for evaluation formation constants and summarising well-field history.- Transaction. Amer. Geophys. Union, Vol. 27,S.526-534, 5Abb., 1Tab.; Richmond, Va.

Coward, M.P., Dietrich, D. \& Park R.G. (Hrsg.), 1989. Alpine tectonics. Geological Society Special Publications, 45, 450 S., Oxford.

Daniel, J.-M., Moretti, I., Micarelli, L., Essautier-Chuyne, S.D. \& Piane, C., 2004. Macroscopic structural analysis of AG10 well (Gulf of Corinth, Greece). C. R. Geoscience Vol.336, p. 435444.

De Wever, P. et al., 1982. Geological Map of Greece, Kandhila Sheet. Institute of Geology and Mineral Exploration (IGME), Athens.

Degnan, P.J. \& Robertson, A.H.F., 1998. Mesozoic-early Tertiary passive margin evolution of the Pindos ocean. NW-Peloponnese, Greece. Sedimentary Geology, 117, 33-70.

Dercourt, J., 1964. Esquisse tectonique du Péloponnèse septentrional (Grèce). Ann. Soc. Géol. Nord 84 (3), p. 183-189.

Dercourt, J., Flament, J.-M., Fleury, J.-J. \& Meiliez, F., 1973. Stratigraphie des couches situées sous les Radiolarites de la zone du Pinde-Olonos (Grèce). le Trias supérieur et la Jurassique inférieur. Ann. Géol. Pays Hellen., Vol. 25, No.1, 397-406.

DGG (Hrsg.), 1999. Hydrogeologische Modelle - ein Leitfaden für Auftraggeber, Ingenieur-büros und Fachbehörden in der Grundwasserwirtschaft: Arbeitskreis „Hydrogeologische Modelle“ der Fachsektion Hydrogeologie in der Dt. Geol. Ges., Schriftenreihe der DGG, Heft 10.

Diersch, H.-G., 2005. Feflow 5.2 user manual. WASY Institute for Water Resources Planning and Systems Research Ltd., Berlin.

Doutsos, T. \& Kokkalas, S., 2001. Stress and deformation patterns in the Aegean region. J. Structural Geol., 23, 455-472.

Doutsos, T. \& Piper. D.J.W., 1990. Listric faulting, sedimentation, and morphological evolution of the Quaternary eastern Corinth rift, Greece. First stages of continental rifting, Geological Society of America Bulletin, Vol. 102, p. 812-829.

Doutsos, T. \& Poulimenos, G., 1992. Geometry and kinematics of active faults and their seismotectonic significance in the western Corinth-Patras rift (Greece). J. Structural Geol., 14, 6, 689-699.

Doutsos, T., Kontopoulos, N. \& Ferentinos, G., 1985. Das westliche Ende des Korinth-Grabens. Neues Jb. Geol. Paläont. 11, 652-666.

Doutsos, T., Kontopoulos, N. \& Frydas, D., 1987. Neotectonic evolution of nortwestern continental Greece. Geol.Rundsch. 76, 433-450.

Doutsos, T., Kontopoulos, N. \& Poulimenos, G., 1988. The Corinth-Patras rift as the initial stage of continental fragmentation behind an sctive island arc (Greece). Basin Res. 1, 177-190.

Doutsos, T., Koukouvelas, I.K., Poulimenos, G., Kokkalas, S., Xypolias, P. \& Skourlis, K., 2000. An exhumation model of the south Peloponnesus, Greece. Int. J. Earth Sci., 89, 350-365. 
Doutsos,T., Piper, G., Boronkay, K. \& Koukouvelas, I.K., 1993. Kinematics of the Central Hellenides. Tectonics, 12, 936-953.

Doveton, J.H.,1994a. Geologic log analysis using computer methods. Tulsa, AAPG Computer Applications in Geology, No. 2, 167 pp.

Doveton, J.H., 1994b. Geologic log interpretation. SEPM Shourt Course No.29: Society for Sedimentary Geology (SEPM), Tulsa, Oklahoma, USA.

Doveton, J.H., 2002. Geological analysis of logs: Rock compositions, facies analysis, and pattern in time and space. Script and lecture notes, Kansas Geological Survey (KGS), University of Kansas, Lawrence, USA.

Duffield, G.M., 1999. AQTESOLV for Windows. Users guide by Hydrosolv, Inc., Reston, UK.

Dupuit, J., 1863. Etudes théorétiques et pratiques sur le mouvement des eaux dans les canaux découverts et à travers les terrains perméables.- 2.Aufl.. XXVIII + 304 S..

DVWK, 1992. Deutscher Verband für Wasserwirtschaft und Kulturbau e.V., Entnahme und Untersuchungsumfang von Grundwasserproben. Schriftenreihe des DVWK 128, 36S.

DVGW, 1995. Planung, Durchführung und Auswertung von Pumpversuchen bei der Wassererschließung. DVGW Regelwerk, Technische Regeln W111.

Eckl, H., 1979. Beitrag zum Gebirgsbau des NE-Peloponnes im Grenzbereich Olonos-Pindos-Zone / Gavrovo-Tripolitza-Zone. Z. dt. Geol. Ges., 130, 347-351.

Eisbacher, G.H., 1996. Einführung in die Tektonik. 2. Aufl., 374 S.

Ferentinos, G., Brooks, M. \& Doutsos, T., 1985. Quaternary tectonics in the Gulf of Patras, Western Greece. J.struct.Geol., 7, 713-717.

Fleury, J.-J., 1980. Les zone de Gavrovo-Tripolitza et du Pinde-Olonos (Gréce continentale et Péloponnèse du Nord). Evolution $d^{\text {' }}$ une plate-forme et $d^{\text {' } u n ~ b a s s i n ~ d a n s ~ l e ~ c a d r e ~ a l p i n . ~ S o c . ~}$ Géol. Nord. Publ., Vol. 4, 651 S., Villeneuve d'Ascq.

Förster, A., Schrötter, J., Merriam, D.F., \& Blackwell, D.D., 1997. Application of optical-fiber temperature logging - An example in a sedimentary environment. Geophysics, 62 (4), p. 1107-1113.

Förster, A., Hötzl, H., Rettenmaier, D. \& Kück, J., 2006. Petrophysical and temperature logging in the ICDP AIG10 borehole (Greece). Scientific Drilling Database. doi: 10.1594 /GFZ. SDDB.1091 (<http://dx.doi.org/10.1594/GFZ.SDDB.1091>).

Füchtbauer, H. et al, 1988. Sedimentpetrologie Teil II: Sedimente und Sedimentgesteine, 4. Aufl., Schweizerbart'sche Verlagsbuchhandlung, 660 Abb., 113 Tab., $1141 \mathrm{~S}$.

Furtak, H. \& Langguth, H.R., 1967. Zur hydrochemischen Kennzeichnung von Grundwässern und Grundwassertypen mittels Kennzahlen. Mem. IAH-Kongress, 1965, VII, 86-96.

Fytikas, M.D. \& Kolios, N.P., 1979. Preliminary heat flow map of Greece. In: Cermak, V. and Rybach, L., eds, Terrestrial Heat Flow in Europe, Springer, New York, 197-205.

Gautier, P., Brun, J.-P., Moriceau, R., Sokoutis, D., Martinod, J.\& Jolivet, L., 1999. Timing, kinematics and cause of Agean extension: a scenario based on a comparison with simple analogue experiments. Tectonophysics, 315, 31-72.

Ghisetti, F.C., Vezzani, L., Agosta, F., Sibson, R. \& Moretti, I. 2001. unpbl.. Tectonic setting and sedimentary evolution of the southern west margin of the Corinth rift. Aigion-Xylocastro area. DGLab-Corinth, unpublished report, Catania/Paris. 
Giurgea, V., Rettenmaier, D., Pizzino, L., Hötzl, H., Förster, A., Quattrocchi, F.\& Nikas, K., 2003. Hydrogeological conditions of the Aigion-Eliki seismic active region based on borehole observations and hydraulic tests. $2^{\text {nd }}$-Corinth Rift Laboratory Workshop Aigion (Greece), Abstracts, Institut de Physique du Globe Paris, page 30.

Giurgea, V., Rettenmaier, D., Pizzino, L., Unkel, I., Hötzl, H., Förster, A.\& Quattrochi, F., 2004. Preliminary hydrogeological interpretation of the Aigion area from the AIG10 borehole data. C. R. Geoscience, 336, 467-475.

Giurgea, V.I., Hötzl, H., Förster, A. \& Rettenmaier, D., 2001. Thermo-hydraulic conditions in the area of the „Gulf of Corinth Deep Geodynamic Laboratory”: Interpretation from well-logging and modelling. Corinth Rift Laboratory Workshop, Aigion, Greece, abstracts, Institut de Physique du Globe Paris, page 13.

Goldsworthy, M., \& Jackson, J., 2001. Migration of activity within normal fault systems: examples from the Quaternary of mainland Greece. Journal of Structural Geology 23, 489-506.

Hantush, M.S. \& Jacob, C.E., 1955. Non-steady radial flow in an infinite leaky aquifer. Am. Geophys. Union Trans., Vol. 36, 95-100.

Hantush, M.S., 1960. Modification of the theory of leaky aquifers. Jour.of geophys. Res., Vol.65, No.11, pp. 3713-3725.

Hantush, M.S., 1962. Flow of groundwater in sands of non-uniform thickness; 3. Flow to wells. Jour. Geophys. Res., Vol. 67, No.4, 1527-1534.

Hantush, M.S., 1961a. Drawdown around a partially penetrating well. Jour. of the Hyd. Div. of the Am. Soc. of Civil Eng., Vol.87, No.HY4, pp. 83-89.

Hantush, M.S., 1961b. Aquifer test on partially penetrating wells. Jour. of the Hyd. Div. of the Am. Soc. of Civil Eng., Vol.87, No.HY5, pp. 171-194.

Hatzfeld, D., 1994. On the shape of the subducting slab beneath the Peloponnese. Greece. Geophys. Res. Lett., 21, 3, 173-176.

Hölting, B., 1991. Geogene Grundwasserbeschaffenheit und ihre regionale Verbreitung in der Bundesrepublik Deutschland.- in: Rosenkranz et al.. Handbuch Bodenschutz, 6. Lfg., I/91; $1300,36 \mathrm{~S}$.

Hölting, B., 1996. Hydrogeologie: Einführung in die Allgemeine und Angewandte Hydrogeologie. 4.Aufl. , Enke, $415 \mathrm{~S}$.

Hötzl, H. et al., 1995. Auswertung und Interpretation hydrogeologischer Daten. unveröff. Skriptum am Lehrstuhl für Angewandte Geologie, Karlsruhe.

Hötzl, H., Breh, W. \& Liesch, T, 1999. Hydrogeologie III. Vorlesungsskript, Version 1.1, unveröff. Skriptum am Lehrstuhl für Angewandte Geologie, Karlsruhe.

Hurtig, E., Schrötter, J., Großwig, S., Kühn, K., Harjes, B., Wieferig, W., \& Orrell, R.P., 1993. Borehole temperature measurements using distributed fibre optic sensing. Scientific Drilling. 3 (6), p. 283-286.

Jackson , J. A. et al, 1982. Seismicity, normal faulting, and the geomorphological development of the Gulf of Corinth (Greece): the Corinth eartquakes of February and March 1981. Earth and Planetary Science Letters, 57 (1982) 377-397.

Jacobshagen, V. (Hrsg.), 1986. Geologie von Griechenland. Beitr. Reg. Glied. Erde, 19, Gebr. Bornträger (Berlin), $363 \mathrm{~S}$.

Jacobshagen, V., 1980. Die eozäne Orogenese in der Ägäis. Berliner Geowiss. Abhandl. A20, 21-33. 
Jacobshagen, V., Dürr, St., Kockel, F., Kopp, K.-O. \& Kowalczyk, G. 1978. Structure and geodynamic evolution of the Aegean region,.in: Closs, H., Roeder, D. \& Schmidt, K. (eds.).

Jacobshagen, V., Makris, J., Richter, D., Bachmann, G.H., Doert, U., Giese, P. \& Risch, H., 1976a. Alpidischer Gebirgsbau und Krustenstruktur des Peloponnes. Z.dt.geol.Ges. 127, 337-363, $7 \mathrm{Abb}$.

Jacobshagen, V., Risch, H. \& Roeder, D., 1976b. Die eohellenische Phase, Definition und Interpretation. Z.dtsch.Geol.Ges. 127, 133-145.

Jolivet, L., 2001. A comparsion of geodetic and finite strain pattern in the Aegean, geodynamic implications. Earth and Planetary Science Letters 187, 95-104.

Jordan , H., \& Weder, H.J., 1995. Hydrogeologie: Grundlagen und Methoden. 2.Aufl., Enke.

Kahle, H.G. et al., 2000. GPS-strain rate field within the boundary zones of the Eurasian, African and Arabican plates. J.Geophys.Res. 105, 23353-23370.

Kelletat, D., Kowalczyk, G., Schroder, B. \& Winter, K.P., 1976. A Synoptic View on the Neotectonic Development of the Peloponnesian Coastal Regions. Z.dtsch.Geol.Ges. 127, 447-465.

Keraudren, B. \& Sorel, D., 1987. The Terraces of Corinth (Greece); a detailed record of eustatic sealevel variations during the last 500,000 years. Marine Geology, Vol. 77, No. 1-2, 99-107, Amsterdam.

Kinzelbach, W. \& Rausch, R., 1995. Grundwassermodellierung. 283 p., Bornträger, Berlin, Stuttgart.

Kober, L., 1929. Beiträge zur Geologie von Attika. Sitz.-Ber.Akad.Wiss. Wien, math.-naturw. Kl.,(I),138 (7),299-327.

Kolditz, O., 1997. Strömung, Stoff- und Wärmetransport im Kluftgestein. - 263 S., Gebr. Bornträger Verlag; Berlin Stuttgart.

Koukouvelas, I.K. \& Doutsos, T., 1996. Implications of structural segmentation during earthquakes: the 1995 Egion earthquake, Gulf of Corinth, Greece. J.Structural Geol., 18, 12, 1381-1388.

Koukouvelas, I.K., 1998. The Egion fault, earthquake-related and long-term deformation, Gulf of Corinth, Greece. J. Geodyn., 26, No.2-4, 501-513.

Koukouvelas, I.K., Asimakopoulos, M. \& Doutsos, T., 1999. Fractal characteristics of active normal faults: an example of the eastern Gulf of Corinth, Greece. Tectonophysics, 308, 263-274.

Koukouvelas, I.K., Stamatopoulos, L., Katsonopoulou, D. \& Pavlides, S., 2001. A palaeoseismological and geoarchaeological investigation of the Eliki fault, Gulf of Corinth, Greece. J.Structural Geol., 23, 531-543.

Kowalczyk, V., Richter, D., Risch, H. \& Winter, K.P., 1977. Zur zeitlichen Einstufung der tektogenetischen Ereignisse auf dem Peloponnes. N.Jb.Geol.Paläol.Mn. 9, 549-564.

Krusemann, G.P. \& DeRidder, N.A., 1991. Analysis and Evaluation of Pumping Test Data. 277 S..

Kunz, E., 1976. Der Gebirgsbau im Grenzbereich Gavrovo-Tripolitza-Zone gegen Olonos-PindosZone im NE-Peloponnes. Annales géologiques des pays helléniques, 28, 567-581.

Laigle, M., Sachpazi, M. \& Hirn, A., 2004. Variation of seismic coupling with slab detachment and upper plate structure along the western Hellenic subduction zone. Tectonophysics 391, 85-95.

Langguth, H.R. \& Voigt, R, 1980. Hydrogeologische Methoden. 486 S., Springer-Verlag BerlinHeidelberg-New York.

Le Pichon, X. \& Angelier, J., 1979. The Hellenic arc and trench system: a key to the neo-tectonic evolution of the eastern Mediterranean area. Tectonophysics, 60, 1-42. 
Lemeille, F., Chatoupis, F., Foumelis, M., Rettenmaier, D., Unkel, I., Micarelli, L., Moretti, I., Bourdillon, C., Guernet, C. \& Müller, C., 2004. Recent syn-rift deposits in the hanging wall of the Aigion Fault (Gulf of Corinth, Greece). C. R. Geoscience, 336, 425-434.

Lykousis, V. \& Sakellariou,D., 2001. Offshore active faults in the Gulf of Corinth, Greece. Corinth Rift Laboratory Aigion Workshop, Sep.30-Oct.4-2001, Greece.

Matthess, G. \& Ubell, K., 1983. Lehrbuch der Hydrologie Band1: Allgemeine Hydrogeologie Grundwasserhaushalt. 438 S. Gebr. Borntraeger, Berlin Stuttgart.

Matthess, G., 1990. Die Beschaffenheit des Grundwassers - 2. Auflage. 498 S..

Matthess, G., Frimmel, F.H., Hirsch, P., Schulz, H.D. \& Usdowski, E., 1992. Progress in Hydrogeochemistry. 544 S., (Springer) Heidelberg.

Mc Kenzie, D., 1972. Active tectonics of the Mediterranean region. Geophys. J. R. Astr. Soc., 30, 109-185.

Micarelli, L., Moretti, I. \& Daniel, J. M., 2003. Structural properties of rift-related normal faults: the case study of the Gulf of Corinth, Greece. Journal of Geodynamics, Vol. 36, 275-303.

Militzer; H., Schön, J. \& Stötzner, U., 1986. Angewandte Geophysik im Ingenieur- und Bergbau. 2. überarb. u. erw. Aufl.. Enke.

Moench, A.F., 1984. Double-porosity models for a fissured groundwater reservoir with fracture skin, Water Resources Research. Vol.20, No.7, pp. 831-846.

Moench, A.F., 1985. Transient flow to a large-diameter well in an aquifer with storative semiconfining layers, Water Resources Research. Vol.21, No.8, pp. 1121-1131.

Moench, A.F., 1997. Flow to a well of finite diameter in a homogeneous, anisotropic water table aquifer, Ground Water. Vol.33, No.6, 1397-1407.

Moench, A.F., 1993a. Computation of type curves for flow to partially penetrating wells in water-table aquifers. Ground Water. Vol.31, No.6, 966-971.

Moench, A.F., 1993b. Flow to a well in a water-table aquifer: an improved Laplace transform solution. Ground Water. Vol.34, No.4, 593-596.

Moretti, I., Sakellariou, D., Lykoudid, V. \& Micarelli, L., 2003. The Gulf of Corinth: an active half graben?. J. Geodyn. 36, 323-340.

Neumann, P. et al., 1996. Die stratigraphische und sedimentologische Entwicklung der OlonosPindos-Serie zwischen Koroni und Finikounda (SW-Messenien, Griechen-land). N.Jb. Geol. Paläont. Abh., 200, 3, 405-424.

Neumann, P, 2003. Ablagerungsprozesse, Event- und Biostratigraphie kreidezeitlicher Tiefwassersedimente der Tethys in der Olonos-Pindos-Zone Westgriechenlands. Münchner Geowiss Abh A40:1-156.

Neumann, S.P., 1974. Effect of partial penetration on flow in unconfined aquifers consi-dering delayed gravity response, Water Resources Research. Vol.10, No.2, pp. 303-312.

Nikas, K., 2001a. Hydrogeological research project „Investigation-Evaluation of water resources in north Peloponnesus“. Subproject of Achaia Prefecture, maps 7, 11, 18, I.G.M.E. (Institute of Geological \& Mineralogical Exploration).

Nikas, K., 2001b. Hydrology of the tectonically active zone of North Achaia, Corinth Rift. Laboratory Aigion Workshop, Greece.

Norden, B. \& Förster, A., 2006. Thermal conductivity and radiogenic heat production of sedimentary and magmatic rocks in the Northeast German Basin. AAPG Bulletin, V. 90, p. 939-962. 
Ori, G.G., 1989. Geological history of the extensional basin of the Gulf of Corinth (?MiocenePleistocene), Greece. Geology, v.17, 918-921.

Papadopoulos, I.S. \& Cooper, H.H., 1973. Drawdown in a well of large diameter, Water Resources Research. Vol.3, pp. 241-244.

Papazachos, B.C., Karakostas, V.G., Papazachos, C.B. \& Scordilis, E.M., 2000. The geometry of the Wadati-Benioff zone and lithospheric kinematics in the Hellenic arc. Tectonophysics, 319, 275-300.

Perissoratis, C., Piper, D.J.W. \& Lykousis, V., 2000. Alternating marine and lacustrine sedimentation during late Quaternary in the Gulf of Corinth rift basin, central Greece. Mar. Geol. 167, 391411.

Piper, A.M., 1944. A graphic procedure in the geochemical interpretation of water analysis. Trans.Am.Geophys.Union, 25, 914-928, Washington D.C..

Piper, D.J.W. \& Pe-Piper G.,1980. Was there a western (external) source of terrigeneous sediment for the Pindos Zone of the Peloponnese (Greece). N. Jahrb. Geol. Paläont. Mh. p. 107-115.

Piper, D.J.W., Kontopoulos, N., Anagnostou, C., Chronis, G. \& Panagos, A.G., 1990. Modern fan deltas in the western Gulf of Corinth, Greece. Geo-Marine Letters, Vol. 10, No. 1, 5-12, Strondsburg.

Pizzino, L., Quattrocchi, F., Cinti, D. \& Galli, G., 2004. Fluid geochemistry along the Eliki and Aigion seismogenic segments (Gulf of Corinth, Greece). C.R. Geoscience, v.336, p. 367-374.

Popov, Y.A., Pribnow, D.F.C., Sass, J.H., Williams, C.F. \& Burkhardt, H., 1999. Characterization of rock thermal conductivity by high-resolution optical scanning. Geothermics, v. 28, p. 253-276.

Popov, Y.A., Semionov, V.G., Korosteliov, V.M. \& Berezin, V.V., 1983. Non-contact evaluation of thermal conductivity of rocks with the aid of a mobile heat source. Izvestiya, Physics of the Solid Earth, v. 19, p. 563-567.

Popov, Y.A., Berezin, V.V., Semionov, V.G. \& Korosteliov, V.M., 1985. Complex detailed investigations of the thermal properties of rocks on the basis of a moving point source. Izvestiya, Physics of the Solid Earth, v. 21, p. 64-70.

Poulimenos, G., 1993. Tectonics and sedimentation in the western Corinth graben, Greece. N. Jb. Geol. Paläont. Mh., H.10, 607-630.

Poulimenos, G., Albers, G. \& Doutsos, T., 1989. Neotectonic evolution of the Central Section of the Corinth Graben. Z.dtsch.Geol.Ges. 140, 173-182.

Poulimenos, G., Zeilidis, A., Kontopoulos, N. \& Doutsos, T., 1993. Geometry of the trapezoidal fan deltas and their relationship to extensional faulting along the south-western margins of the Corinth rift, Greece. Basin Research, 5, 179-192.

Prioul, R., Plona, T., Kane, M., Sinha, B., Kaufman, P. \& Signer, C., 2004. Azimuthal anisotropy using shear dipole sonic. insights from the AIG 10 well, Corinth Rift Laboratory. C. R. Geoscience Vol.336, p. 477-485.

Rausch, R., Schäfer, W., Therrien, R. \& Wagner, C., 2005. Solute transport modelling: An introduction to models and solution strategies. Gebr. Borntraeger Science Publishers, Berlin, Stuttgart.

Renz, C., 1940. Die Tektonik der griechischen Gebirge. Pragm.Akad. Athen, 8, 1-171.

Renz, C., 1955. Die vorneogene Stratigraphie der normalsedimentären Formationen Griechenlands. 637 S., Athen (Inst.Geol.Subsurf.Res.). 
Rettenmaier, D., 2002. Europäische Erdbebenzone Golf von Korinth: Geologisch-tektonische und hydrogeologische Untersuchungen in der Region Egion und Klokos (NW-Peloponnes, Griechenland). Unpubl. Diploma Thesis, Dept. of Applied Geology, University of Karlsruhe, $116 \mathrm{pp}$.

Rettenmaier, D., 2003. Geological conditions in the AIG10 borehole and technical aspects of drilling through the Aigion seismic active fault zone. $2^{\text {nd }}$-Corinth Rift Laboratory Workshop Aigion (Greece), Abstracts, Institut Physique du Globe Paris, p. 24.

Rettenmaier, D., Giurgea, V. \& Hötzl, H., 2002b. Darstellung und Bewertung der geologischtektonischen und hydrogeologischen Verhältnisse im Bereich der Egion-Tiefbohrung AIG 10 für die geplanten Bohrarbeiten sowie weiteren wissenschaftlichen Untersuchungen. Unpubl. Report, Dept. of Applied Geology, University of Karlsruhe, 22 pp.

Rettenmaier, D., Giurgea, V., Förster, A. \& Hötzl, H., 2006. Thermo-hydraulic conditions in the area of the "Gulf of Corinth Deep Geodynamic Laboratory": Interpretation from well-logging and modeling. - DFG/IODP-ICDP Joint Colloquium Greifswald, scientific program and abstracts.

Rettenmaier, D., Giurgea, V., Hötzl, H. \& Förster, A., 2004. The AIG10 drilling project (Aigion, Greece): interpretation of the litho-log in the context of regional geology and tectonics. C. R. Geoscience Vol. 336, p. 415-423.

Rettenmaier, D., Giurgea, V., Hötzl, H., Förster, A. \& Nikas, K., 2002a. Geological mapping and hydrogeological testing of the block-faulted system in the hinterland of Egion. 27th General Assembly Europ. Geophys. Soc., Nice, (France), CD.

Rettenmaier, D., Wohlgemuth, L., Kück, J., Borm, G. \& Harms, U., 2003. Drilling, coring, testing and instrumentation of the AIG10 borehole, Aigion, Gulf of Corinth, Greece. ICDP Newsletter, Vol. 5, GeoForschungsZentrum Potsdam, 20-23.

Richter, D. 1976. Das Flysch-Stadium der Helleniden - Ein Überblick. Z.dtsch.Geol.Ges. 127, 467483.

Richter, D., \& Müller, C., 1993. Der „Erste Flysch“ in der Pindos-Zone (Griechenland)?. N.Jb.Geol.Paläont. Mh., (4), 209-246, Stuttgart.

Richter, D., 1993. Die Flysch-Zonen Griechenlands VI. Zur Stratigraphie des Flysches der PindosZone zwischen der Querzone von Kastaniotikos und dem Südpeloponnes (Griechenland). N. Jb. Geol. Paläont. Mh. H. 8, 449-476, Stuttgart.

Rigo, A., Lyon Caen, H., Armijo, R., Deschamps, A., Hatrzfeld, D., Makioupouos, K., Papadimitriou, P. \& Kassaras, I., 1996. A microseismic study of the western part of the Gulf of Corinth (Greece): implications for the large-scale normal faulting mechanisms. Geophys. J. Int. 126, 663-688.

Risch, H., 1976. Alpidischer Gebirgsbau und Krustenstruktur des Peloponnes. Z. dt. Geol. Ges., 127, 337-363.

Robertson, Ahf, Clift, P.D., Degnan, P.D. \& Jones, G., 1991. Palaeogeographic and papaeotectonic evolution of the eastern Mediterranean Neothethys. Palaeogeogr. Palaeoclimatol. Palaeoecol. 87, p. 298-343.

Sachpazi, M., Clement, C., Laigle, M., Hirn, A. \& Roussos, N., 2003. Rift structure, evolution, and earthquakes in the Gulf of Corinth, from reflection seismic images. Earth and Planetary Science Letters 216, 243-257.

Schlumberger, C., 1991. Log Interpretation Principles/Applications. Schlumberger Charts, Basic Material. 
Schöneberg, R. \& Neugebauer, J. 1997. Einführung in die Geologie Europas. 7.Aufl., Rombach Wissenschaft, 385 S., Freiburg.

Skourlis, K. \& Doutsos, T., 2003. The Pindos Fold-and-thrust belt (Greece): inversion kinematics of a passive continental margin. Int. J. Earth Sci. (Geol. Rundschau), 92, 891-903.

Sorel, D., 2000. A Pleistocene and still-active detachment fault and the origin of the Corinth-Patras rift (Greece). Geology 28(1), 83-86.

Soter, S., 1999. Macroscopic seismic anomalies and submarine pockmarks in the Corinth-Patras rift, Greece. Tectonophysics, 308, 275-290.

Steinwachs, M. \& Henseleit, O., 1995. Das Erdbeben am 15. Juni 1995 in Ägion, Griechenland. Deutsches Task Force Komitee Erdbeben.

Stiros, S.C., 1991. Heat flow and thermal structure of the Aegean Sea and the southern Balkans. In: Cermak, V. \& Rybach, L., eds, Terrestrial Heat Flow in Europe, Springer, New York, 395416.

Streltsova, T.D., 1974. Well Testing in heterogeneous formations. John Wiley \& Sons, New York, $413 p$.

Suess, E., 1901. Das Antlitz der Erde. Band 3,1-IV, 508 pp, (dt.).

Theis, C.V., 1935. The relation between the lowering of the piezometric surface and the rate and duration of discharge of a well using groundwater storage. Am.Geophys.Union Trans., Vol.16, pp.519-524.

Tiberi, C. et al., 2000. Crustal and upper mantle structure beneath the Corinth rift (Greece) from a teleseismic tomography study. J. Geophys. Res., 105, B12, 28,159-28,171.

Tiberi, C., Diament, M., Lyon-Caen, H. \& King, T., 2000. Moho topography beneath the Corinth Rift area (Greece) from inversion of gravity data. Geophysical Journal International 145, 797-808.

Tselentis, G. \& Makropoulos, K., 1986. Rates of crustal deformation in the Gulf of Corinth (Central Greece) as determined from seismicity. Tectonophysics, 124, 55-66.

Unkel, I., 2003. Europäische Erdbebenzone Golf von Korinth: Geologisch-hydrogeologische Untersuchungen in der Region Aigion im Umfeld der kontinentalen Tiefbohrung AIG10 (NWPeloponnes, Griechenland). Unpubl. Diploma Thesis, Dept. of Applied Geology, University of Karlsruhe, 153 pp.

Westaway, R., 2002. The Quaternary evolution of the Gulf of Corinth, central Greece: coupling between surface processes and flow in the lower continental crust. Tectonophysics, 348, 269318.

Weisbach, J., 1845. Lehrbuch der Ingenieur- und Maschinenmechanik. (3 Bde., 1845/1863).

Witthüser, K., 2002. Untersuchungen zum Stofftransport in geklüfteten Festgesteinen unter besonderer Berücksichtigung der Matrixdiffusion. - Schriftenreihe Angewandte Geologie Karlsruhe, Dissertation, 64, 145 S.; Karlsruhe.

Woodside, W., \& Messmer, J., 1961a. Thermal conductivity of porous media. I Unconsolidated sands. Journal of applied Pysics, v.32, p.1688-1699.

Woodside, W., \& Messmer, J., 1961b. Thermal conductivity of porous media. II Unconsolidated sands. Journal of applied Pysics, v.32, p.1699-1706.

Wortel, M.J.R. \& Spakman, W., 1992. Structure and dynamics of subducted lithosphere in the Mediterranean region. Proc. Kon. Ned. Akad. V. Wetensch., 95, 3, 325-347. 
Xypolias, P. \& Doutsos, T., 2000. Kinematics of rock flow in a crustal-scale shear zone: implication for the orogenic evolution of the southwestern Hellenides. Geol. Mag. 137 (1), 2000, pp. 8196. Cambridge University Press.

Zelt, B.C., Taylor, B., Sachpazi, M. \& Hirn, A. 2005. Crustal velocity and Moho structure beneath the Gulf of Corinth, Greece. Geophys. J. Int. Vol. 162, Iss. 1. 


\section{List Of Figures (shortened)}

Fig. I.1: Overall concept of the project task---_-- 2

Fig. II.1: Modified NASA Satellite image of the Aegean region -------------------------------------- 5

Fig. II.2: Overview of the study area -------------------------------------- 6

Fig. II.3: Tilted blocks of solid deposits of Gilbert-type delta conclomerates -------------------------- 7

Fig. II.4: Strong relief prevailing in the southern Achaia prefecture ------------------------------- 8

Fig. II.5: Temperature analysis of water samples at Aigion and in the Klokos mountains ------------ 9

Fig. II.6: Precipitation map of the Achaia prefecture----------------10

Fig. II.7: Hydrographic network of the Achaia prefecture --

Fig. II.8: Annual temperature and precipitation of Patras ---

Fig. III.1: Geologal-tectonical overview of Greece ----------------------------13

Fig. III.2: Tectonical overview and plate boundaries of the Aegean region --

Fig. III.3: Historical Instrumental seismicity in the Mediterranean region--------------------------18

Fig. III.4: The seismogenic zone after Rigo et al., 1996 ---------- 20

Fig. IV.1: Geological-tectonical overview of the Aigion area and AIG 10 drill site----------------23

Fig. IV.2: Simplified geological-tectonical map and overview of normal faults -------------------24

Fig. IV.3: Faults ruptured at surface during the 1995 earthquake on the Aigion fault---------------24

Fig. IV.4: Radiolarite of the Olonos-Pindos Formation ---

Fig. IV.5: Outcrop at the Peleniko Mt. showing the Olonos-Pindos Platy Limestone Formation ------27

Fig. IV.6: The Tertiary Pindos Flysch Formation ---

Fig. IV.7: Block-faulted Neogene and Quaternary syntectonic deposits -----------------------29

Fig. IV.8: Lacustrine, lagoonal, brackish and marine environment ----------------------- 30

Fig. IV.9: Gilbert-type delta conglomerates---------------------------------------------------31

Fig. IV.10: Examples of Quaternary deposits ---------------------------------------- 31

Fig. IV.11: Cross section of the Alpine overthrusted Olonos-Pindos nappe-------------------------32

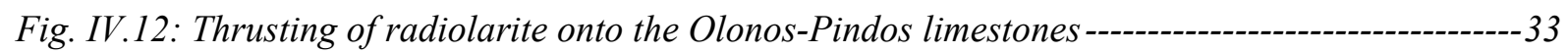

Fig. IV.13: Stereographic projection of strike- and dip directions on thrust faults------------------- 34

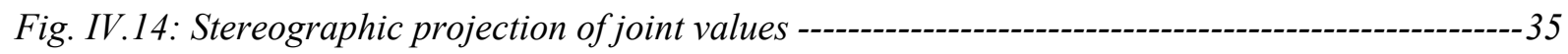

Fig. IV.15: Stereographical analysis of prevailing fold structures ------------------------------ 37

Fig. IV.16: Fault escarpment of the Ponti normal fault------------ 38

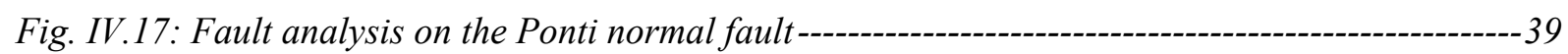

Fig. IV.18: Stereographic projection of the Ponti normal fault------------------------ 40

Fig. IV.19: Pyrgaki fault $1 \mathrm{~km}$ to the west of the Pyrgaki village---

Fig. IV.20: Pyrgaki fault plane in the center of the mapped area ---

Fig. IV.21: Kinematic indicators on the Melissia fault plane ---------------------------42

Fig. IV.22: Geological cross section E-F from the Melissia fault to the Kerynia fault --------------43

Fig. IV.23: The Eliki fault outcropping to the south of Aigion-------- 44

Fig. IV.24: Tectonical striae on the Eliki fault plane----------------------------------44

Fig. IV.25: Eliki fault characteristics when arranged in between delta conglomerates---------------- 45

Fig. IV.26: The E-W striking synthetic Aigion normal fault---

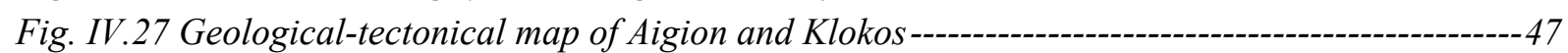

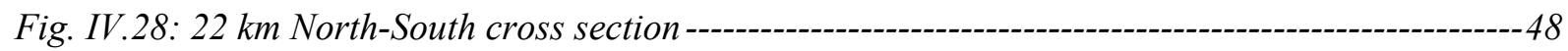


Fig. V.1: History of the drilling process in AIG10------ 49

Fig. V.2: Generalized Litho-Log of AIG10 ---

Fig. V.3: Detailed succession from $450 \mathrm{~m}$ down to $705 \mathrm{~m}$ depth in AIG10 ---

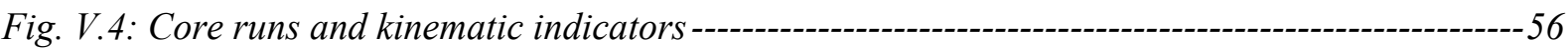

Fig. V.5: Core run 19 from 759-763 m, showing the Aigion normal fault in $760 \mathrm{~m}$ depth----------57

Fig. V.6: Interpretation of core analyses in the Aigion fault zone------------- 58

Fig. V.7: Schematic NNW-SSE cross section of the Selinous pumping test site --------------62

Fig. V.8: Time-depended drawdown and recovery phase for the Selinous test-------------------63

Fig. V.9: Processing of the Selinous test results for Olonos-Pindos platy limestones -----------------63

Fig. V.10: Hydrochemical analysis and Piper diagram of the Selinous water samples ------------65

Fig. V.11: Schematic litho-log of the AIG10 borehole with hydrostratigraphy ------------------66

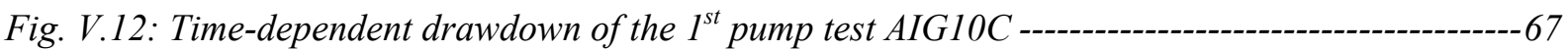

Fig. V.13: Processing results of the $1^{\text {st }}$ pump test AIG10C----on

Fig. V.14: Time-dependent drawdown of the $1^{\text {st }}$ pump test AIG10C ---

Fig. V.15: Processing results of the $2^{\text {nd }}$ pump test AIG10L-------- 70

Fig. V.16: Results of hydrochemical analysis of the production test---------------------------72

Fig. V.17: Tritium from nuclear bomb tests detected in the precipitation at Athens Airport-----------73

Fig. V.18: Interpretation of the spectral gamma ray log ---------------------------- 77

Fig. V.19: Spectral gamma ray log into the components Uranium, Potassium, and Thorium ---------79

Fig. V.20: Lithological interpretation of the travel times Deltatime 1 and Deltatime 2---------------82

Fig. V.21: Formation porosity derived from the sonic log by the Wyllie time average equation ------- 85

Fig. V.22: Principle of the interval method applied to the temperature gradient data---------------87

Fig. V.23: DTS temperature log and temperature gradient derived from AIG10 borehole------------- 88

Fig. V.24: Temperature gradient for four lithological intervals based on regression analysis --------- 89

Fig. V.25: Plots of temperature and geothermal gradient versus depth-----------------------91

Fig. VI.1: Principle of the optical scanning device for Thermal Conductivity Scanning----------------92

Fig. VII.1: Conceptual hydrogeological model -----on

Fig. VII.2: Hydrogeological map of the northern part of the study area-------------------97

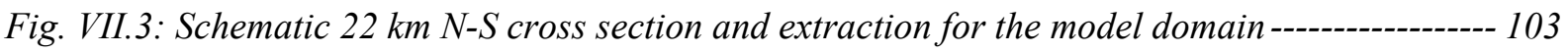

Fig. VII.4: TMesh-Delaunay-generated mesh for the 2-D vertical problem ---

Fig. VII.5: Supermesh generated for the 2-D vertical problem ------------------------------ 105

Fig. VII.6: Distribution of hydraulic head in version [A] --- 112

Fig. VII.7: Distribution of hydraulic head in version [B] --------------113

Fig. VII.8: Distribution of hydraulic head in version $[C]$------------ 114

Fig. VII.9: Hydraulic head in observation points OP 1 - 10--- 115

Fig. VII.10: Modeled temperature profiles of the hydraulically calibrated model version [A] ------- 122

Fig. VII.11: Modeled temperature profiles of the hydraulically calibrated model version [B] ------- 122

Fig. VII.12: Correlation of the calculated temperature values in the observation points------------ 123

Fig. VII.13: Modeled temperature profiles of the hydraulically calibrated model version [C] ------- 124

Fig. VII.14: Modeled local temperatures of the hydraulically calibrated model version [C] -------- 126

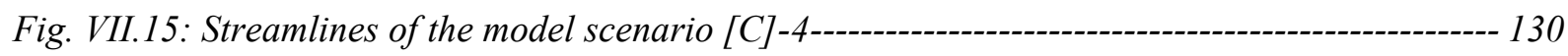

Fig. VII.16: Results and temperature distribution of the calibrated thermo-hydraulic model [C]-4-131

Fig. VII.17: Modeled temperature profiles of [C]-4 and [D] vs. DTS-log --- 133

Fig. VII.18: Correlation of observation points from model scenario [C]-4 with the scenario [D]--- 134 


\section{List Of Tables}

(shortend)

Tab. II.1: Average values for temperature and precipitation in Patras $-11$

Tab. IV.1: Stratigraphical overview of the Olonos-Pindos Formation 25

Tab. V.1: Drill parameters which were taken into consideration 51

Tab. V.2: Parameters determined online on cuttings for lithological analysis -------------------51

Tab. V.3: Relevant parameters determined online on cores for lithological core analysis ------------52

Tab. V.4: Recent synrift sediment units encountered in AIG10 ---

Tab. V.5: Used Type Curve solutions provided by AQTESOLV for Windows 2.5-Professional --------61

Tab. V.6: Derivation of the hydraulic parameters performed in the Selinous valley -------------------64

Tab. V.7: Derivation of the hydraulic parameters performed in the Meganitas valley------------------ 65

Tab. V.8: Content of Tritium in the groundwater samples------

Tab. V.9: Logging activities and derived properties -------------------------------------- 76

Tab. V.10: Compilation of sonic log tool characteristics--

Tab. V.11: Compilation of sonic log measuring characteristics ---

Tab. V.12: Summary of averaged well-log porosities derived from sonic log determination------------86

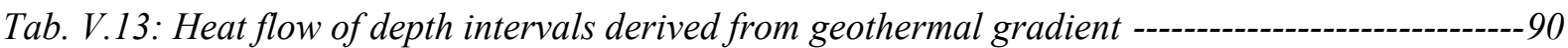

Tab. VI.1: TC, porosity, density and lithotype of investigated samples------------14

Tab. VI.2: Laboratory derived and porosity corrected values for thermal conductivity ---------------95

Tab. VII.1: Distribution of observation points OP1-10 along the AIG10 borehole------------------- 106

Tab. VII.2: Summary of values and conditions for the calibrated hydraulic models --------------- 111

Tab. VII.3: Matrix related thermal conductivities and expected numbers after modeling ------------ 118

Tab. VII.4: Thermal conductivities attached to the fault elements ----------118

Tab. VII.5: Well log derived porosity attached to the supermesh elements --------------- 119

Tab. VII.6: Heat flow of depth intervals derived along the AIG10 borehole profile----------------- 120

Tab. VII.7: Comparison of thermal conductivities in model scenario [C]-4------------------ 125

Tab. VII.8: Summary of values and startings conditions for the model [A] ----------------------- 127

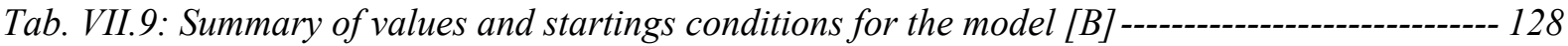

Tab. VII.10: Summary of values and startings conditions for the model [C] -----------------129 


\section{Appendix}

\section{Legend for the analyzed geophysical logs; figures V.6, V.21, V.22, V.23:}

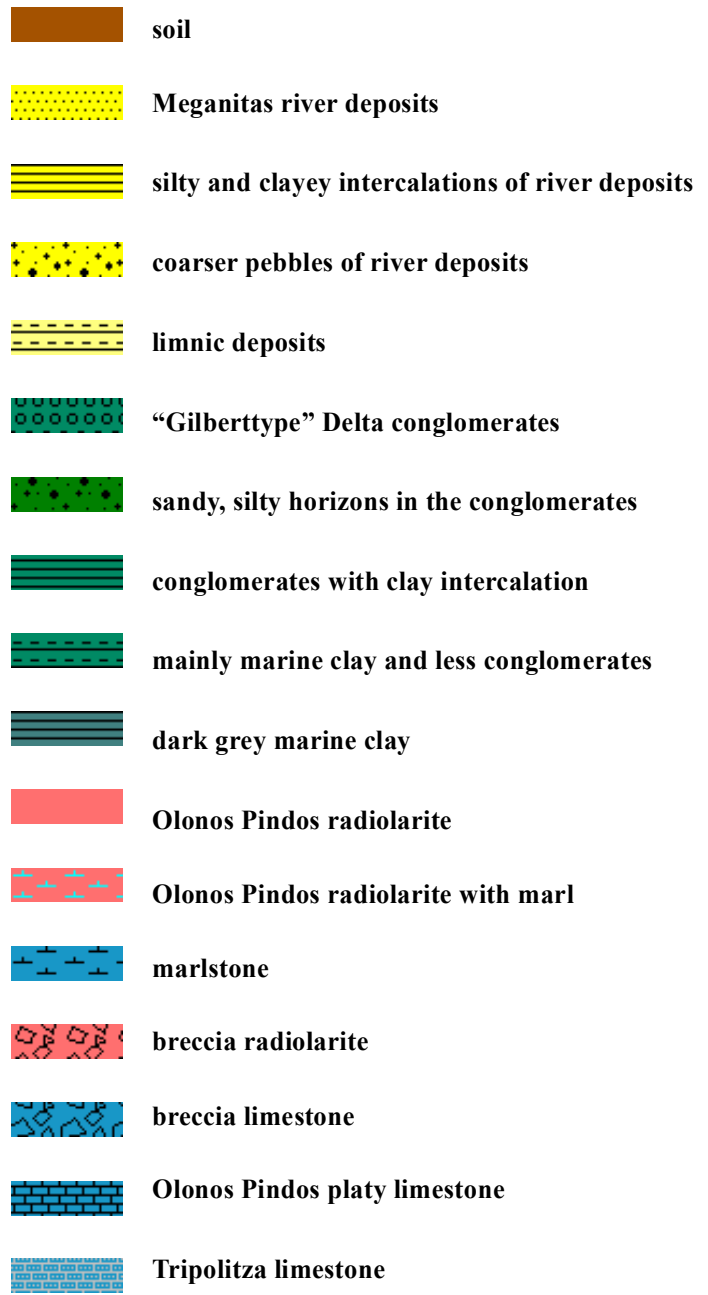

\section{Mnemonics:}

Delta Time:

$\mathrm{Vp}$ :

slowness P-wave:

slowness S-wave:

$\mathrm{K}, \mathrm{U}, \mathrm{Th}$ :

GR:

RILD:

RILM:

MSFL:

Mud Res:

DTS Log:

inverse velocity $[\mu \mathrm{m} / \mathrm{s}]$; (Delta1runtime T1; Delta2 runtime R1) sonic first arrival velocity $[\mathrm{m} / \mathrm{s}]$ analyzed P-wave velocity from sonic $\log [\mu \mathrm{m} / \mathrm{s}]$ analyzed S-wave velocity from sonic $\log [\mu \mathrm{m} / \mathrm{s}]$ Potassium, Uranium, Thorium from gamma ray spectoscopy total gamma ray [gAPI]

induction resistivity (deep) [Ohmm] induction resistivity (medium) [Ohmm] micro resistivity (very shallow) [Ohmm] mud resistivity [Ohmm] Distributed Optical Fibre Sensing: temperature $\left[{ }^{\circ} \mathrm{C}\right]$ distance of measuring points $1 \mathrm{~m}$; gradient in ${ }^{\circ} \mathrm{C} / 1 \mathrm{~km}$ 


\section{Acknowledgement}

This PhD thesis was realized at the Department of Applied Geology (AGK) of the Karlsruhe University (TU) in cooperation with the GeoForschungsZentrum Potsdam (GFZ), Germany. It was kindly supervised by Prof. Dr. H. Hötzl (AGK) together with Dr. habil. Andrea Förster (GFZ). First of all I would like to thank them for the possibility to accomplish my $\mathrm{PhD}$ thesis within the framework of an international research project and for supporting me in completing this thesis with valuable suggestions and discussions.

During the project Dr. Vlad Giurgea (AGK) was involved as the project tutor and I am very grateful for his continuous support and interest in my studies. I would like to thank him for inspiring and motivating discussions, helpful comments and corrections during the last years of team work and friendship.

Special thanks are addressed to Prof. Theodor Doutsos $\uparrow$ and Dr. I.K. Koukouvelas of the Patras University which supervised the field work at the beginning of the investigations and the literature study. The investigations were also supported by the Institute of Geology and Mineral Exploration in Athens (IGME). Contacts with General Director G. K. Gekas and A. Morfis (IGME, Athens) were made and data gathered from IGME's files were incorporated. Special thanks are addressed to Dr. Kostas Nikas (IGME Athens) for his continuous advice in practical, theoretical and language problems and the coordination of the shallow pumping tests in the Selinous and Meganitas river valleys and their implementation.

The AIG10 borehole was performed under the supervision of the Operational Support Group (OSG) from GFZ Potsdam and the author as geologist in charge. In this context I would like to thank Lothar Wohlgemuth for his friendliness and his support during my stay at the AIG10 drill site. The OSG performed a series of geophysical well logs in the borehole and I like to thank Jochem Kück (GFZ) for geophysical discussion and helpful comments.

The borehole was drilled by the German contractor Bohrgesellschaft Rhein Ruhr (BRR) with a B5R drilling rig. For their efforts with drilling including several barbecue parties I would like to give special thanks to the Tool Pusher Egon Zech and the Drilling Engineer Reiner Jatho. It was a pleasure to work with them and their drillers and roughnecks.

I would like to thank the EU project coordinator Prof. Cornet from the Institut de Physique du Globe de Paris (IPGP) and his staff for the collaboration during the DFG project work.

The online analysis of well cuttings from the graben sediments were analyzed in collaboration with Francis Lemeille from the Institut de radioprotection et de sûreté nucléaire (IRSN) and I thank him for the high spirits at the drill site and his helpful comments to the litho-log.

The results of the core interpretation are also supported by the team of Dr. Isabelle Moretti from Institut Français du Pétrole (IFP), Carole Frima, and Jean-Marie Mengus and I would like to thank for the fruitful team work at the drill site and the provision of core samples. 
All hydrochemical data were analyzed at the Istituto Nationale di Geofisica e Vulcanogia (INGV) in Rome and I want to thank Prof. F. Quattrocchi and "mio amico" Dr. Luca Pizzino for the close collaboration and the valuable hints to hydrochemical aspects of the study area.

Many thanks to Prof. Aeschbach-Hertig, Institute of Environmental Physics (IUP) at the University of Heidelberg for the Tritium dating of the water samples and to V. Leonardi (UMR Sisyphe Paris) (Trapetza well) and S. Michalopoulou, Translator (Olive oil factory, several pump owners) for the admission to take water samples.

Temperature logging instruments (DTS) were provided by the instrument pool of the GFZ Potsdam, Section 5.2, Geothermics under the responsibility of Dr. Andrea Förster. Many thanks for the possibility to analyse thermal parameters at the laboratory of the section.

I couldn't have had a better guide in teaching geophysical analysis than John Doveton and Dan Merriam of the Kansas Geological Survey (KGS) at the University of Kansas. I really appreciated their help and support during my stay at their department and I will never forget the kindness and hospitality they offered me.

I would like to thank my diploma students Ingmar Unkel and Eckhard Bauer for their fruitful teamwork and field- and hydraulic test analysis. They provided the geological maps in digital form that contributed to this thesis.

Last but not least, an enjoyable non-geoscientific environment is very important. I am grateful to the family Palassopoulos for the hospitality and the good times I spent with them in Greece. I will never forget the kindness they offered me. First of all I want to thank Alex Palassopoulos and his friends for translation help and for his introduction in the Greek culture. Furthermore I am grateful to Sophia Michalopoulou which was a great Greek translation helper at the drill site and which taught me the good manners of the Greek.

I'm grateful to Heike Werz, Tanja Liesch, Leif Wolf, Jochen Klinger, Marc Ludewig, Mitsch Ruff and Olaf Eisen for fruitful discussions, language review, corrections and technical support. My appreciation goes to all my colleagues at the University of Karlsruhe for the good time, and excellent cooperation.

For the understanding, serenity and their continuous kindly encouragement I am very grateful to my wife Heike and my son Finn. Moreover, I am much obliged to my parents and sister and all my family members for their support and patience, especially during the final months. Thanks. 